\title{
GROUND-WATER HYDRAULICS, REGIONAL FLOW, AND GROUND-WATER DEVELOPMENT OF THE FLORIDAN AQUIFER SYSTEM IN FLORIDA AND IN PARTS OF GEORGIA, SOUTH CAROLINA AND ALABAMA
}

\section{REGIONAL AQUIFER-SYSTEM ANALYSIS}

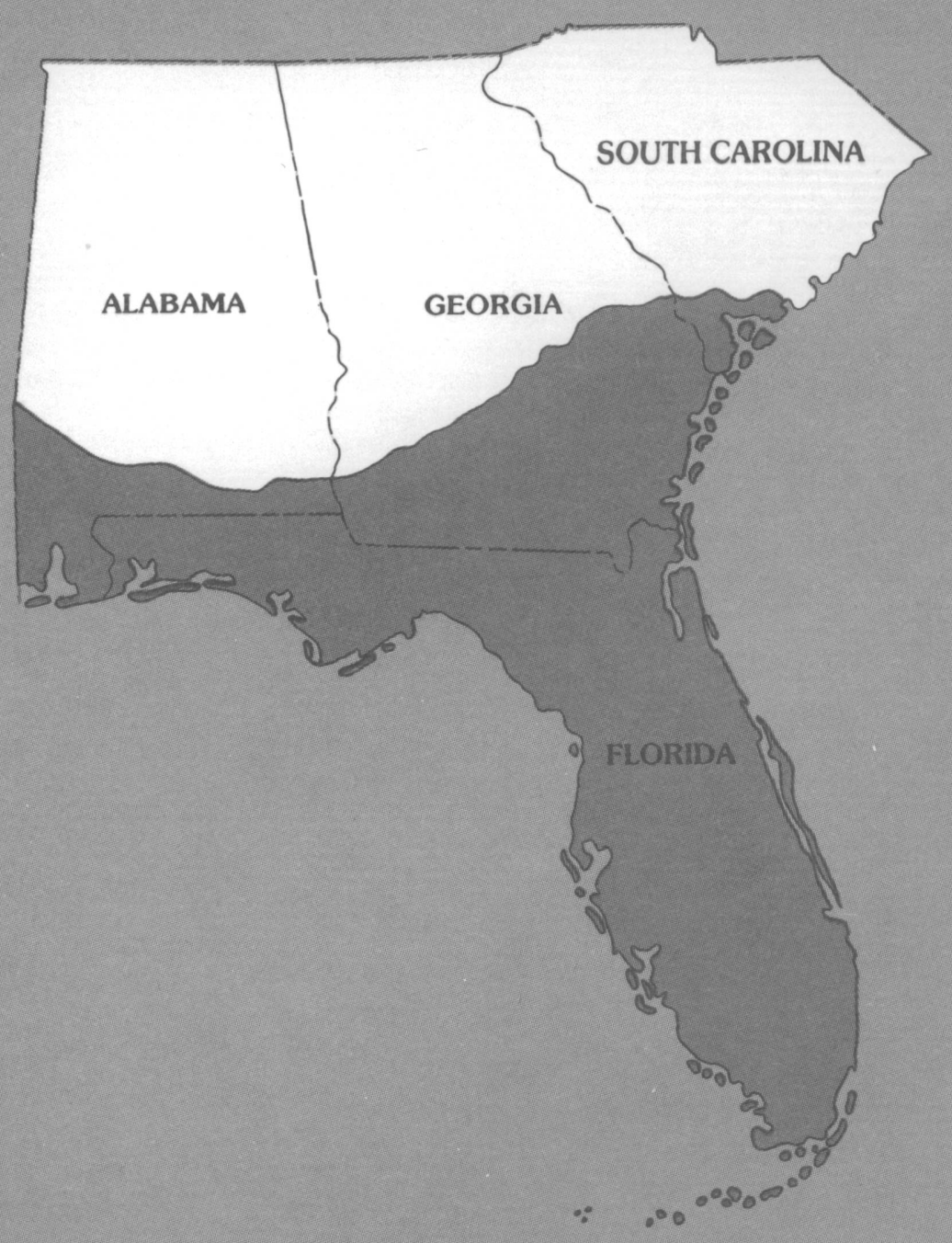




\section{Ground-Water Hydraulics, Regional Flow, and Ground-Water Development of the}

Floridan Aquifer System in Florida and in Parts of Georgia, South Carolina, and Alabama By PETER W. BUSH and RICHARD H. JOHNSTON REGIONAL AQUIFER-SYSTEM ANALYSIS

U.S. GEOLOGICAL SURVEY PROFESSIONAL PAPER 1403-C

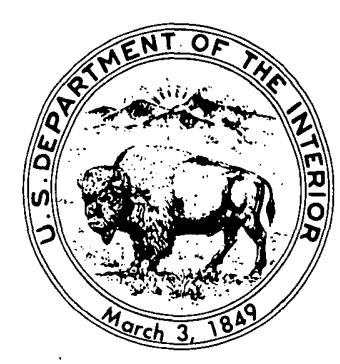




\section{DEPARTMENT OF THE INTERIOR}

DONALD HODEL, Secretary

\section{U.S. GEOLOGICAL SURVEY}

Dallas L. Peck, Director

Library of Congress Cataloging-in-Publication Data

Bush, Peter W.

Ground-water hydraulics, regional flow, and ground-water development of the Floridan aquifer system in Florida and in parts of Georgia, South Carolina, and Alabama.

(Regional aquifer-system analysis) (U.S. Geological Survey professional paper ; 1403-C) Bibliography: $\mathbf{p}$.

Supt. of Docs. no.: I 19.16:1403

1. Water, Underground-Southern States. 2. Groundwater flow-Southern States. 3. Water resources development-Southern States. 4. Floridan Aquifer. I. Johnston, Richard H. II. Title. III. Series. GB1018.B87 1988 551.49'0975 86-607940

For sale by the Books and Open-File Reports Section, U.S. Geological Survey Federal Center, Box 25425, Denver, CO 80225 


\section{FOREWORD}

\section{THE REGIONAL AQUIFER-SYSTEM ANALYSIS PROGRAM}

The Regional Aquifer-System Analysis (RASA) Program was started in 1978 following a congressional mandate to develop quantitative appraisals of the major ground-water systems of the United States. The RASA Program represents a systematic effort to study a number of the Nation's most important aquifer systems, which in aggregate underlie much of the country and which represent an important component of the Nation's total water supply. In general, the boundaries of these studies are identified by the hydrologic extent of each system and accordingly transcend the political subdivisions to which investigations have often arbitrarily been limited in the past. The broad objective for each study is to assemble geologic, hydrologic, and geochemical information, to analyze and develop an understanding of the system, and to develop predictive capabilities that will contribute to the effective management of the system. The use of computer simulation is an important element of the RASA studies, both to develop an understanding of the natural, undisturbed hydrologic system and the changes brought about in it by human activities, and to provide a means of predicting the regional effects of future pumping or other stresses.

The final interpretive results of the RASA Program are presented in a series of U.S. Geological Survey Professional Papers that describe the geology, hydrology, and geochemistry of each regional aquifer system. Each study within the RASA Program is assigned a single Professional Paper number, and where the volume of interpretive material warrants, separate topical chapters that consider the principal elements of the investigation may be published. The series of RASA interpretive reports begins with Professional Paper 1400 and thereafter will continue in numerical sequence as the interpretive products of subsequent studies become available.

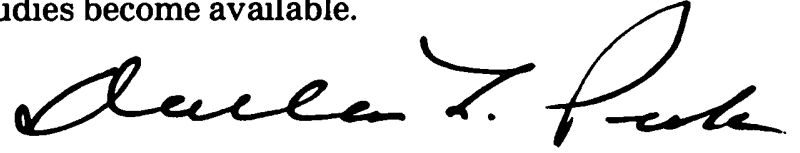

Dallas L. Peck Director 


\section{CONTENTS}

Abstract

Introduction

Summary of previous work $\ldots \ldots \ldots \ldots \ldots \ldots \ldots \ldots$

Hydrogeology

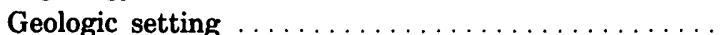

Floridan aquifer system $\ldots \ldots \ldots \ldots \ldots \ldots \ldots \ldots$

Hydraulic properties of the aquifer system $\ldots \ldots \ldots \ldots \ldots$

Transmissivity

Aquifer tests $\ldots$

Nilo Plantation test $\ldots \ldots \ldots \ldots \ldots \ldots \ldots$

Doctortown test $\ldots \ldots \ldots \ldots \ldots \ldots \ldots \ldots \ldots$

Dunnellon test $\ldots \ldots \ldots \ldots \ldots \ldots \ldots \ldots \ldots \ldots$

Green Swamp test $\ldots \ldots \ldots \ldots \ldots \ldots \ldots \ldots \ldots$

Specific-capacity data $\ldots \ldots \ldots \ldots \ldots \ldots \ldots$

Areal distribution of transmissivity $\ldots \ldots \ldots \ldots \ldots$

Upper Floridan aquifer $\ldots \ldots \ldots \ldots \ldots \ldots \ldots$

Lower Floridan aquifer $\ldots \ldots \ldots \ldots \ldots \ldots \ldots \ldots$

Storage coefficient $\ldots \ldots \ldots \ldots \ldots \ldots \ldots \ldots \ldots$

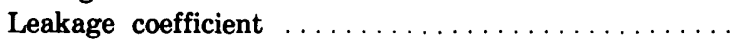

Upper confining unit

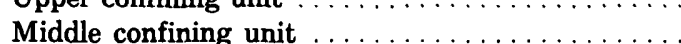

\begin{tabular}{r|} 
Page \\
1 \\
1 \\
2 \\
2 \\
3 \\
3 \\
4 \\
6 \\
8 \\
8 \\
12 \\
12 \\
14 \\
16 \\
17 \\
19 \\
19 \\
20 \\
21 \\
25 \\
25 \\
26
\end{tabular}

The regional flow system $\ldots \ldots \ldots \ldots \ldots \ldots \ldots \ldots \ldots \ldots$

Regional flow model $\ldots \ldots \ldots \ldots \ldots \ldots \ldots \ldots \ldots \ldots$

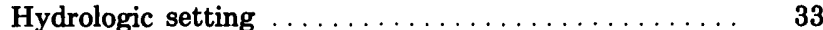

Rainfall ..................... 34

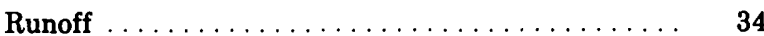

Evapotranspiration $\ldots \ldots \ldots \ldots \ldots \ldots \ldots \ldots \ldots$

Hydrologic budget $\ldots \ldots \ldots \ldots \ldots \ldots \ldots \ldots \ldots$

The predevelopment flow system $\ldots \ldots \ldots \ldots \ldots \ldots \ldots$

Recharge, discharge, and circulation ........ 38

Unconfined and semiconfined areas ........ 38

Confined areas $\ldots \ldots \ldots \ldots \ldots \ldots \ldots \ldots \ldots$

Areal and vertical distribution of flow ........ 47

The current flow system $\ldots \ldots \ldots \ldots \ldots \ldots \ldots \ldots \ldots$

Ground-water development $\ldots \ldots \ldots \ldots \ldots \ldots \ldots, \quad 50$

Effects of ground-water development . . . . . . 58

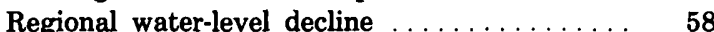

Recharge, discharge, and distribution of ilow . . 62

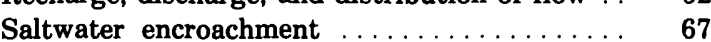

Potential for future development $\ldots \ldots \ldots \ldots \ldots \ldots \ldots$

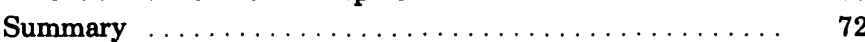

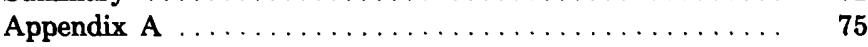

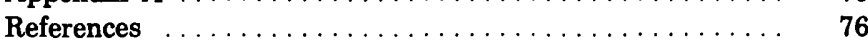

\section{ILLUSTRATIONS}

Plates 1-17. Maps showing:

[Plates are in pocket]

1. Occurrence of confined/unconfined conditions in the Upper Floridan aquifer.

2. Transmissivity of the Upper Floridan aquifer.

3. Leakage coefficient of the upper confining unit of the Floridan aquifer system.

4. Estimated predevelopment potentiometric surface of the Upper Floridan aquifer.

5. Potentiometric surface of the Upper Floridan aquifer, May 1980.

6. Net decline between estimated predevelopment potentiometric surface and observed May 1980 potentiometric surface of the Upper Floridan aquifer.

7. Average rainfall on the land overlying the Upper Floridan aquifer.

8. Average runoff from selected surface-water basins overlying the Upper Floridan aquifer.

9. Estimated evapotranspiration from the land overlying the Upper Floridan aquifer.

10. Locations of Upper Floridan aquifer springs and areas of Upper Floridan aquifer discharge to surface-water bodies.

11. Estimated predevelopment recharge to and discharge (as diffuse upward leakage) from the Upper Floridan aquifer.

12. Estimated Floridan aquifer system pumpage for all uses, by county, 1980

13. Estimated Floridan aquifer system pumpage for public supply, by county, 1980.

14. Estimated Flo:idan aquifer system pumpage for irrigation, by county, 1980.

15. Estimated Floridan aquifer system pumpage for self-supplied industry and thermoelectric power generation, by county, 1980.

16. Estimated changes in recharge to and discharge (as diffuse upward leakage) from the Upper Floridan aquifer due to current (about 1980) pumpage.

17. Most favorable areas for future development of large water supplies from the Upper Floridan aquifer.

Figure 1. Generalized geologic map of the southeastern United States

2. Graph showing logarithmic plot of drawdown versus time for observation well TW-2, Nilo Plantation aquifer test

3. Map showing potentiometric surface of the Upper Floridan aquifer and location of observation wells, Doctortown,

Ga. 
FIGURES 4-12. Graphs showing:

4. Logarithmic plots of recovery versus $\mathrm{r}^{2} / \mathrm{t}$ for observation wells, Doctortown aquifer test $\ldots \ldots \ldots \ldots$ C15

5. Logarithmic plot of drawdown versus time for Tidewater-2 observation well, Dunnellon aquifer test .. 16

6. Logarithmic plots of drawdown versus $t / r^{2}$ for observation wells, Green Swamp aquifer test ....... 17

7. Comparison of transmissivities estimated from specific capacity with model-derived transmissivities .. 18

8. Comparison of transmissivities from multiwell aquifer tests with model-derived transmissivities ..... 19

9. Simulated drawdown versus time for different storage coefficients and pumping rates, Polk County, Fla. 22

10. Simulated drawdown versus time for different storage coefficients and pumping rates, Orange County, Fla. 23

11. Simulated drawdown versus time for different storage coefficients and pumping rates, Savannah, Ga. 23

12. Simulated drawdown versus time for different storage coefficients and pumping rates, Fort Walton Beach, Fla.

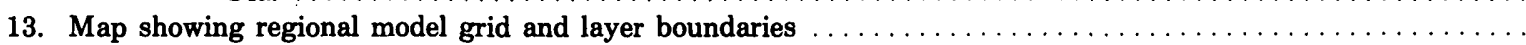

14. Sketch showing vertical structure of the regional flow model $\ldots \ldots \ldots \ldots \ldots \ldots \ldots \ldots \ldots \ldots \ldots \ldots$ 15-16. Maps showing:

15. Relation among subregional and regional flow-model grids $\ldots \ldots \ldots \ldots \ldots \ldots \ldots \ldots \ldots \ldots \ldots \ldots$

16. Net decline between simulated predevelopment potentiometric surface and simulated May 1980 potentiometric

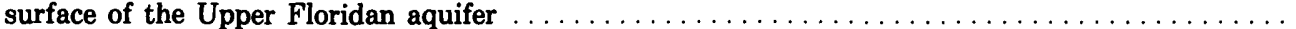

17-18. Schematics showing:

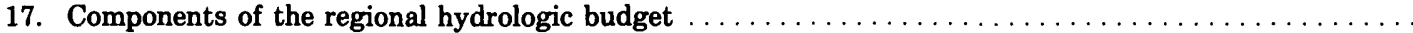

18. Components of the regional hydrologic budget in $A$, predevelopment recharge area; $B$, predevelopment onshore discharge area; $C$, current recharge area; and $D$, current onshore discharge area $\ldots \ldots \ldots \ldots \ldots$

19-20. Maps showing:

19. Typical pattern of topography and drainage in Ocmulgee River area; Floridan aquifer system unconfined

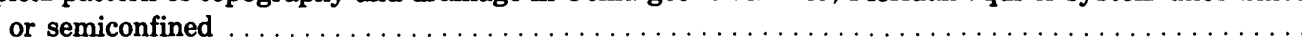

20. Typical pattern of topography and drainage in Suwannee River area; Floridan aquifer system unconfined

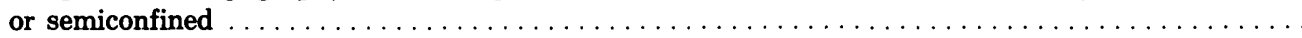

21. Sketch showing idealized flow patterns in the Floridan aquifer system $\ldots \ldots \ldots \ldots \ldots \ldots \ldots \ldots \ldots \ldots \ldots \ldots$

22. Map showing estimated predevelopment discharge from major ground-water basins of the Upper Floridan aquifer

23. Schematic showing simulated predevelopment components of flow among units associated with the Floridan aquifer system

24-27. Graphs showing:

24. Estimated Floridan aquifer system pumpage for all uses, $1950-80 \ldots \ldots \ldots \ldots$

25. Estimated Floridan aquifer system pumpage for public supply and rural use, $1950-80 \ldots \ldots \ldots \ldots$

26. Estimated Floridan aquifer system pumpage for irrigation, $1950-80 \ldots \ldots \ldots 5$

27. Estimated Floridan aquifer system pumpage for self-supplied industry and thermoelectric power generation, 1950-80

28. Diagram showing percentage of Floridan aquifer system pumpage by category, 1950 and $1980 \ldots \ldots \ldots \ldots$

29-31. Graphs showing:

29. Hydrograph of Upper Floridan aquifer well in southeast Georgia area of regional water-level decline .

30. Hydrograph of Upper Floridan aquifer well in west-central Florida area of regional water-level decline

31. Hydrograph of Upper Floridan aquifer well in panhandle Florida area of regional water-level decline .

32-33. Maps showing:

32. Estimated current (about 1980) discharge from major ground-water basins of the Upper Floridan aquifer

33. Sources of water supplying simulated pumpage (about 1980) from the Floridan aquifer system (assuming

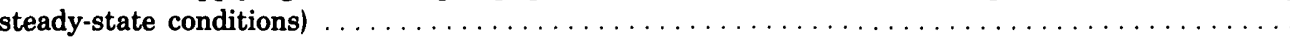

34. Schematic showing simulated components of flow (about 1980) among units associated with the Floridan

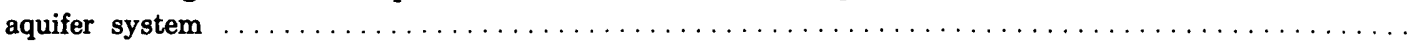

\section{TABLES}

TABLE 1. Aquifers and confining units of the Floridan aquifer system $\ldots \ldots \ldots \ldots \ldots \ldots \ldots \ldots \ldots \ldots \ldots \ldots \ldots \ldots \ldots \ldots \ldots$

2. Summary of transmissivity, storage coefficient, and leakage coefficient values for the Upper Floridan aquifer .....

3. Transmissivity and hydrogeologic conditions of the Upper Floridan aquifer and the upper confining unit in various localities

4. Observed Upper Floridan aquifer discharge from springs and estimated Upper Floridan aquifer discharge to surface-water bodies

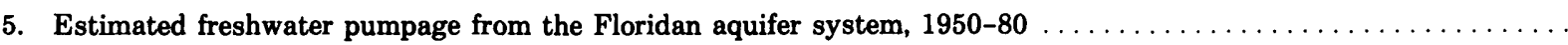




\section{CONVERSION FACTORS}

For readers who prefer to use SI units rather than inch-pound units, conversion factors for terms used in this report are listed below:

\begin{tabular}{|c|c|c|}
\hline Multiply & $B y$ & To obtain \\
\hline feet (ft) : & 0.3048 & meters (m) \\
\hline miles (mi) & 1.609 & kilometers (km) \\
\hline square miles $\left(\mathrm{mi}^{2}\right)$ & 2.590 & square kilometers $\left(\mathrm{km}^{2}\right)$ \\
\hline $\begin{array}{l}\text { million gallons per day } \\
(\mathrm{Mgal} / \mathrm{d})\end{array}$ & 0.04381 & $\begin{array}{l}\text { cubic meters per second } \\
\left(\mathrm{m}^{3} / \mathrm{s}\right)\end{array}$ \\
\hline gallons per minute (gal/min) & 0.06309 & liters per second $(\mathrm{L} / \mathrm{s})$ \\
\hline $\begin{array}{l}\text { cubic feet per second } \\
\left(\mathrm{ft}^{3} / \mathrm{s}\right)\end{array}$ & 0.02832 & $\begin{array}{l}\text { cubic meters per second } \\
\left(\mathrm{m}^{3} / \mathrm{s}\right)\end{array}$ \\
\hline inches per year (in./yr) & 25.4 & $\begin{array}{l}\text { millimeters per year } \\
(\mathrm{mm} / \mathrm{yr})\end{array}$ \\
\hline $\begin{array}{l}\text { square feet per day } \\
\left(\mathrm{ft}^{2} / \mathrm{d}\right)\end{array}$ & 0.0929 & $\begin{array}{l}\text { square meters per day } \\
\left(\mathrm{m}^{2} / \mathrm{d}\right)\end{array}$ \\
\hline
\end{tabular}




\title{
GROUND-WATER HYDRAULICS, REGIONAL FLOW, AND GROUND-WATER DEVELOPMENT OF THE FLORIDAN AQUIFER SYSTEM IN FLORIDA AND IN PARTS OF GEORGIA, SOUTH CAROLINA, AND ALABAMA
}

\author{
By Peter W. Bush and Richard H. JOHnston
}

\section{ABSTRACT}

The Floridan aquifer system is one of the major sources of groundwater supplies in the United States. This productive aquifer system underlies all of Florida, southeast Georgia, and small parts of adjoining Alabama and South Carolina, for a total area of about 100,000 square miles. About 3 billion gallons of water per day were withdrawn from the aquifer system in 1980, and in many areas the Floridan is the sole source of freshwater.

The Floridan aquifer system is a sequence of hydraulically connected carbonate rocks (principally limestone with some dolomite) ranging in age generally from late Paleocene to early Miocene. The rocks vary in thickness from a featheredge where they crop out to more than 3,500 feet where the aquifer is deeply buried. The aquifer system generally consists of an upper aquifer and a lower aquifer separated by a lesspermeable confining unit of highly variable properties. In parts of north Florida and southwest Georgia, where little permeability contrast exists among the units, the Floridan is effectively one continuous aquifer. The upper and lower aquifers, named the Upper Floridan aquifer and the Lower Floridan aquifer, are defined on the basis of permeability and their boundaries locally do not coincide with those for either time-stratigraphic or rock-stratigraphic units.

Overlying much of the Floridan aquifer system are low-permeability clastic rocks. The lithology, thickness, and integrity of these rocks determine the degree of confinement and influence the distribution of natural recharge, discharge, and ground-water flow in the Floridan.

The permeability of the Floridan aquifer system is derived from small openings including fossil hashes and solution-widened joints as well as large cavernous openings in karst areas. Diffuse flow predominates where the small openings occur, whereas conduit flow may occur where large cavernous openings are. Transmissivities are highest (greater than 1,000,000 feet squared per day) in the unconfined karst areas of central and northern Florida. Lowest transmissivities (less than 50,000 feet squared per day) occur in panhandle Florida and southernmost Florida where the Upper Floridan aquifer is confined by thick clay sections. The hydraulic properties of the Lower Floridan aquifer are not well known; however, intervals of high transmissivity occur that have been attributed to paleokarst development.

Springs, nearly all of which occur in unconfined and semiconfined parts of the Upper Floridan aquifer in Florida are the dominant feature of the Floridan flow system. Before ground-water development, spring flow and point discharge to surface-water bodies were about 88 percent of the estimated 21,500 cubic feet per second total discharge, or about 19,000 cubic feet per second. Diffuse upward leakage, which occurs primarily in confined areas, accounted for the remaining 12 percent or about 2,500 cubic feet per second.
Most of the recharge necessary to sustain springflow and aquifer discharge to streams and lakes occurs relatively close to springs and areas of point discharge to surface-water bodies. Recharge to the Upper Floridan is highest, averaging 10-20 inches per year, in unconfined or semiconfined spring areas. The proximity of high recharge to high discharge implies a vigorous and well-developed shallow flow system in the unconfined and semiconfined parts of the Upper Floridan aquifer.

Ground-water flow is very sluggish in the parts of the aquifer system that are deeply buried and tightly confined, primarily southeast Georgia and northeast Florida, south Florida, and far-west panhandle Florida. Discharge to springs, streams, and lakes is practically nonexistent in the tightly confined areas and natural discharge occurs almost exclusively by diffuse upward leakage through thick overburden.

The regional flow system has not been appreciably altered by groundwater development. However, increasing pumpage that reached 3 billion gallons per day by 1980 has resulted in long-term regional waterlevel decline of more than 10 feet in three broad areas: coastal Georgia, adjacent South Carolina, and northeast Florida; west-central Florida; and panhandle Florida. Saltwater encroachment as a result of pumping has occurred iocally in coastal areas.

Pumpage from the Upper Floridan aquifer is supplied primarily by reduction of natural discharge and by increased recharge rather than by depletion of aquifer storage. About 20 percent is from reduced discharge to springs, streams, and lakes, about 20 percent is from reduced upward leakage, and about 60 percent is from increased recharge. Compared to predevelopment conditions, discharge to springs, streams, and lakes is reduced by less than 5 percent, upward leakage is reduced by about 30 percent, and recharge is increased by about 12 percent. Total recharge and, therefore, discharge increased from a predevelopment rate of 21,500 cubic feet per second to about 24,100 cubic feet per second by 1980 .

A considerable area remains of the Floridan aquifer system where large ground-water supplies may be developed. This area is largely inland from the coasts and characterized by high transmissivity and minimal development prior to the early 1980 's. The major constraint on future development probably is degradation of water quality rather than water-quantity limitations.

\section{INTRODUCTION}

The Floridan aquifer system is one of the major sources of ground-water supplies in the United States. The aquifer system underlies an area of about 100,000 $\mathrm{mi}^{2}$ including all of Florida, southeast Georgia, and 
small parts of adjoining Alabama and South Carolina. The Floridan is comprised of several Tertiary carbonate formations that hydraulically act as a regional hydrologic unit. However, locally there are significant differences in its water-bearing properties, water chemistry, and flow.

The Floridan provides water supplies for many cities including Daytona Beach, Jacksonville, Orlando, Tallahassee, and St. Petersburg in Florida and Brunswick and Savannah in Georgia. In many areas it is the sole source of freshwater. Industrial and agricultural pumpage is even larger than pumpage for public supply. Withdrawals for irrigation have increased sharply in recent years.

In 1980 about $3 \mathrm{Bgal} / \mathrm{d}$ were withdrawn from the Floridan. Although this stress has produced areas of regional water-level decline and local cones of depression, more than one-half of the aquifer area has not experienced head declines exceeding $10 \mathrm{ft}$ by the early 1980 's. However, despite the enormous amount of untapped water available from the Floridan, water is not always available where needed locally.

Development has proceeded unevenly with large withdrawals concentrated in a few areas. For example, extensive ground-water development along the coastal strip from Savannah, Ga., to Jacksonville, Fla., where the Floridan is deeply buried, has caused a regional decline in artesian head and significant changes to the flow system. In contrast little ground-water development has occurred in northwest-central Florida, an area with high rates of recharge and very large spring flows.

During 1978-83, the U.S. Geological Survey conducted a regional assessment the Floridan aquifer system that involved the review and synthesis of many previous studies of the Floridan, the acquisition of new data in selected areas, and the extensive use of computer-based digital models to simulate groundwater flow. The results of the Floridan study are presented in USGS Professional Papers 1403-A through 1403-I including this report, Professional Paper 1403-C.

\section{PURPOSE AND SCOPE}

This report describes ground-water hydraulics, regional flow, and the effects of development on the Floridan aquifer system. The hydraulic properties of the aquifers and confining units comprising the Floridan are described. The feasibility of using aquifer-test methods and theory developed for flow in porous media to the solution-riddled carbonate rocks of the Floridan aquifer system is investigated. The history and current status of ground-water development is summarized. Predevelopment water levels are compared to those of 1980 to define changes in the rates and distribution of recharge and discharge caused by development. This analysis was accomplished by computer simulation of the regional flow system. An evaluation of the potential for additional ground-water development is presented.

\section{SUMMARY OF PREVIOUS WORK}

Hundreds of reports describing the hydrology, geology, and water chemistry of the Floridan have been published. Of these, many are referred to throughout the report, but a select few that provided major contributions to the knowledge of the Floridan aquifer system are noted here.

Matson and Sanford (1913) in Florida and Stephenson and Veatch (1915) in Georgia provided the first comprehensive descriptions of the hydrogeology, ground-water resources, and development of the aquifer system on a county-by-county basis. Their interpretations, although based on limited data, provide the best descriptions of the aquifer system prior to extensive development.

The earliest known potentiometric surface map of the Floridan (Gunter and Ponton, 1931) was based on waterlevel measurements made in 1928 and covers most of northern peninsular Florida. The pioneer work of Stringfield in the early 1930's identified a regional flow system in Florida that included several Tertiary limestone units. Stringfield (1936) presented a potentiometric surface map of peninsular Florida that suggested areas of natural recharge and discharge and indicated general directions of ground-water movement. A major area of high head and thus potential recharge was shown to exist in central Florida. Later, Parker and others (1955) concluded that this flow system represented a single hydrologic unit (composed of several Tertiary carbonate formations) and named the unit the "Floridan aquifer."

Important contributions to the paleontology and stratigraphy of the Tertiary limestones include those by Applin and Applin (1944, 1964), Herrick (1961), and Puri and Vernon (1964). Herrick and Vorhis (1963) first recognized and named the "Gulf Trough," an important subsurface structural feature that affects the regional ground-water flow and water chemistry in southeast Georgia.

Saltwater intrusion has occurred locally near some coastal pumping centers. Notable studies of this problem include an early statewide summary in Florida by Black and others (1953); the documentation of lateral intrusion of seawater near Savannah, Ga. (Counts and Donsky, 1963); and an analysis of rising brackish water at Brunswick, Ga. (Wait and Gregg, 1973). 
Ground-water hydraulics studies have proceeded from simplified analytical approaches in the 1940's to computer simulation in recent years. A notable early study was made by Warren (1944) who related widespread changes in artesian head to variation in the pumping rates at Savannah. Warren calculated head declines that would occur with increased pumping. More recently, Counts and Krause (1976) used a computer model to analyze the effects of Savannah pumping. Wilson (1982) used computer simulation to project water-level declines resulting from proposed phosphate mining in westcentral Florida. Solute transport modeling was used by Bredehoeft and others (1976) to simulate the movement of brackish water in the Floridan at Brunswick, Ga.

The definitive reference for the hydrogeology of the Floridan aquifer system is by Stringfield (1966). This 226-page volume presents areal hydrogeologic descriptions (by county) with emphasis on the waterbearing properties of the geologic units comprising the Floridan aquifer system. Considerable hydraulic and geochemical data and regional interpretation are presented.

Hundreds of reports published primarily by the states of Florida and Georgia and in the USGS Open-File and Water-Resources Investigations series provide the basic hydrologic data as well as interpretations of the local hydrology without which this regional analysis could not have been successfully made. Many of these studies were made by the U.S. Geological Survey in cooperation with various state, county, and municipal governments and Florida's water-management districts.

\section{HYDROGEOLOGY}

\section{GEOLOGIC SETTING}

The Coastal Plain province of the Southeastern United States is underlain by a thick sequence of unconsolidated to semiconsolidated sedimentary rocks that range in age from Jurassic to Holocene. Coastal Plain sediments were laid down on an eroded surface developed upon igneous intrusive rocks, low-grade metamorphic rocks, mildly metamorphosed Paleozoic sedimentary rocks, and graben-fill sedimentary deposits of Triassic to Early Jurassic age (Barnett, 1975; Neathery and Thomas, 1975; Chowns and Williams 1983). These sediments thicken seaward in the study area from a featheredge where they crop out against older metamorphic and igneous rocks of the Piedmont and Appalachian provinces to a maximum measured thickness of more than $21,100 \mathrm{ft}$ in Mobile County in southern Alabama and a projected thickness of more than $25,000 \mathrm{ft}$ in south Florida. Coastal Plain rocks generally dip gently toward the Atlantic Ocean or the Gulf of Mexico, except where they are warped or faulted on a local to subregional scale.

The poorly consolidated Coastal Plain sediments are easily eroded. Where they consist of carbonate rocks, the strata are partially dissolved by downwardpercolating water, resulting in the development of karst topography where such rocks are at or near the surface. Accordingly, the topography developed in much of the study area is characterized by extensive, slightly dissected plains; low, rolling hills; and widely spaced drainage. Karst topography of local to subregional extent occurs where limestone is at or near land surface. A series of sandy marine terraces of Pleistocene age has been developed in much of the area.

Coastal Plain sediments in the study area can be separated into two general facies: (1) predominantly clastic rocks, containing minor amounts of limestone, that extend southward and eastward toward the Atlantic Ocean and the Gulf of Mexico from the Fall Line that marks the inland limit of the Coastal Plain and (2) a thick continuous sequence of shallow-water platform carbonate rocks that underlies southeast Georgia and all of the Florida peninsula. In north-central Florida and in southeast Georgia, where these clastic and carbonate rocks generally interfinger with each other, facies changes are both rapid and complex In general, the limestone facies of successively younger units extends progressively farther and farther updip, encroaching to the northwest upon the clastic rocks in an onlap relation-at least until the end of Oligocene time. Miocene and younger rocks comprise-a predominantly clastic facies that, except where removed by erosion, covers the older carbonate rocks everywhere. The various stratigraphic units within both the clastic- and carbonate-rock areas are separated by unconformities that represent breaks in sedimentation.

A generalized geologic map of the southeastern United States (fig. 1) shows that Cretaceous rocks generally crop out in a band adjacent to the crystalline rocks and folded strata of the Piedmont and Appalachian provinces. Rocks of Tertiary age, whose carbonate facies comprise most of the Floridan aquifer system, crop out in a discontinuous band seaward of the Cretaceous sediments and are also exposed in an area in west peninsular Florida. Still farther seaward is a band of outcrop of predominantly clastic rocks of Miocene age, which forms an upper confining unit on the Floridan aquifer system. Miocene rocks generally separate the Floridan from Pliocene and Quaternary strata that are mostly sands and comprise surficial (unconfined) aquifers. 


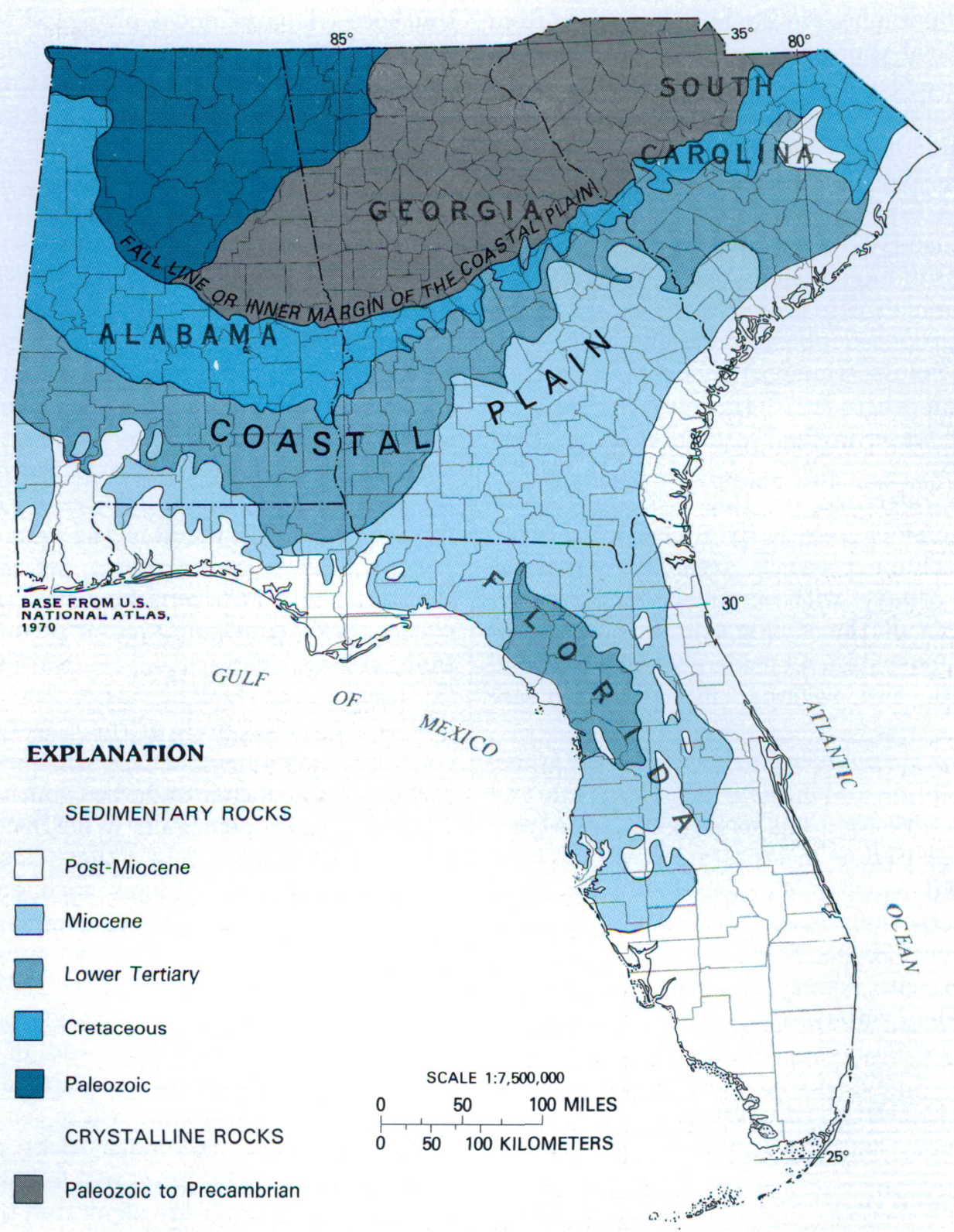

FIGURE 1.-Generalized geologic map of the southeastern United States.

\section{FLORIDAN AQUIFER SYSTEM}

The Floridan aquifer system is defined (Miller, 1986) as a vertically continuous sequence of carbonate rocks of generally high permeability that are of Tertiary age, that are hydraulically connected in varying degrees, and whose permeability is generally several orders of magnitude greater than that of the rocks that bound the system above and below. The Floridan includes units of late Paleocene to early Miocene age. Locally in southeast Georgia, the Floridan includes carbonate rocks of Late Cretaceous age. USGS Professional Paper
1403-B (Miller, 1986) presents a detailed geologic description of the Floridan aquifer system, its component aquifers and confining units, and their relation to stratigraphic units.

Briefly, the top of the Floridan aquifer system represents the top of highly permeable carbonate rock that is overlain by low-permeability material-either clastic or carbonate rocks. Similarly, the base of the Floridan is that level having no high-permeability rock below it. Generally, the underlying low-permeability rocks are either fine-grained clastic materials or bedded anhydrite. These sharp permeability contrasts at the 
top and base of the Floridan commonly occur within, rather than at the vertical boundaries of a formation or a time-stratigraphic unit (Miller, 1982b, 1982d, and 1986). Structure-contour maps of the top and base of the Floridan and related hydrogeologic cross sections are presented in USGS Professional Paper 1403-B (Miller, 1986).

The Floridan aquifer system generally consists of an Upper and Lower Floridan aquifer separated by a lesspermeable confining unit of highly variable properties. In parts of north Florida and southwest Georgia, little permeability contrast is within the aquifer system. Thus in these areas the Floridan is effectively one continuous aquifer. The upper and lower aquifers are defined on the basis of permeability and their boundaries locally do not coincide with those for either time-stratigraphic or rockstratigraphic units. The Floridan gradually thickens from a featheredge at the outcrop area of AlabamaGeorgia-South Carolina to nearly 3,000 ft in southwest Florida. Its maximum thickness is about $3,500 \mathrm{ft}$ in the Manatee-Sarasota County, Fla., area.

Overlying the Floridan aquifer system in much of its area of occurrence are low-permeability clastic rocks that are called the upper confining unit. The lithology, thickness, and integrity of this confining unit has a controlling effect on the development of permeability in the Upper Floridan and the ground-water flow locally.

Plate 1 shows where the Floridan is unconfined or semiconfined (upper confining unit is less than $100 \mathrm{ft}$ thick, breached, or both). Actually the Floridan rarely crops out and the areas designated as "unconfined" generally have either a thin surficial sand aquifer or clayey residuum overlying the Upper Floridan. Sinkholes are common in the unconfined and semiconfined areas and provide hydraulic connection between land surface and the Upper Floridan. In the semiconfined and confined areas, the upper confining unit is mostly the middle Miocene Hawthorn Formation consisting of interbedded sands and clays that are locally phosphatic and contain carbonates. In southwest Florida, the carbonates locally form aquifers. USGS Professional Papers 1403-E and 1403-B describe these local aquifers in detail.

Two important surficial aquifers overlie the upper confining unit locally: (1) the sand-and-gravel aquifer in westernmost panhandle Florida and adjacent Alabama and (2) the very productive Biscayne aquifer (limestone and sandy limestone) of southeast peninsular Florida. Both of these aquifers occur in areas where water in the Floridan is brackish; hence, they are important sources of freshwater in those areas.

The Upper Floridan aquifer forms one of the world's great sources of ground water. This highly permeable unit consists principally of three carbonate units: the
Suwannee Limestone (Oligocene), Ocala Limestone (upper Eocene), and the upper part of the Avon Park Formation (middle Eocene). Detailed local descriptions of the geology and hydraulic properties of the Upper Floridan were provided in many reports listed in the references, especially in the summary by Stringfield (1966). The large variation in transmissivity (up to three orders of magnitude) within the Upper Floridan is presented in the hydraulic properties section of this report, and the geologic reasons for these variations were presented in USGS Professional Paper 1403-B (Miller, 1986).

Within the Upper Floridan aquifer (and the Lower Floridan where investigated) are commonly a few highly permeable zones separated by carbonate rock whose permeability may be slightly less or much less than that of the high-permeability zones. Many local studies on the Floridan have documented these permeability contrasts, generally by using current-meter traverses in uncased wells. For example, Wait and Gregg (1973) observed that wells tapping the Upper Floridan in the Brunswick, Ga., area obtained about 70 percent of their water from the upper $100 \mathrm{ft}$ (approximately) of the Ocala Limestone and about 30 percent from a zone near the base of the Ocala. Separating the two zones is about $200 \mathrm{ft}$ of less-permeable carbonate rock. Leve (1966) described permeable zones of soft limestone and dolomite and less-permeable zones of hard massive dolomite in the Upper Floridan of northeast Florida.

The Upper and Lower Floridan aquifers are separated by a sequence of low-permeability carbonate rock of mostly middle Eocene age. This sequence, called the middle confining unit, varies greatly in lithology, ranging from dense gypsiferous limestones in south-central Georgia to soft chalky limestones in the coastal strip from South Carolina to the Florida Keys. Much of the middle confining unit consists of rock formerly called Lake City Limestone but referred to here as the lower part of the Avon Park Formation.

The Lower Floridan aquifer is less known geologically and hydraulically than the Upper Floridan. Much of the Lower Floridan contains brackish to saline water. For this reason and because the Upper Floridan is so productive, little incentive exists to drill into the deeper Lower Floridan in most areas. The Lower Floridan consists largely of upper Paleocene to early middle Eocene carbonates but locally in southeast Georgia also includes uppermost Cretaceous carbonates. Two important permeable units are within the Lower Floridan: (1) a cavernous unit of extremely high permeability in south Florida known as the Boulder Zone and (2) a partly cavernous permeable unit that occurs in northeast Florida and southeast coastal Georgia herein called the 
Fernandina permeable zone. These units are further described in forthcoming USGS Professional Papers $1403-G$ and 1403-D, respectively.

Table 1 summarizes the geographic occurrence of aquifers and confining units within the Floridan aquifer system and hydrogeologic nomenclature used in forthcoming USGS Professional Papers 1403-D through H. The units given in the table are hydraulic equivalents intended for use in describing and simulating the regional flow system. No stratigraphic equivalency or thickness connotation is intended in this table. For example, the Upper Floridan aquifer in the western Florida panhandle consists principally of the Suwannee Limestone (Oligocene). However, in central Florida the Ocala and Avon Park Formations comprise much of the high-permeability rock in the Upper Floridan. Refer to the USGS Professional Paper 1403-B (Miller, 1986) for stratigraphic equivalency or formation thickness within aquifers and confining units.

\section{HYDRAULIC PROPERTIES OF THE AQUIFER SYSTEM}

Carbonate rocks are nearly always characterized by an uneven distribution of permeability. In general, carbonate aquifers can be characterized as having either diffuse flow or conduit flow where flow occurs along a few solution channels. Classifications of carbonate aquifers based on the type of flow and associated hydrogeologic control have been presented by White (1969) and LeGrand and Stringfield (1971). White's classification emphasizes recent flow conditions whereas the LeGrand and Stringfield classification emphasizes the

TABLE 1.-Aquifers and confining units of the Floridan aquifer system

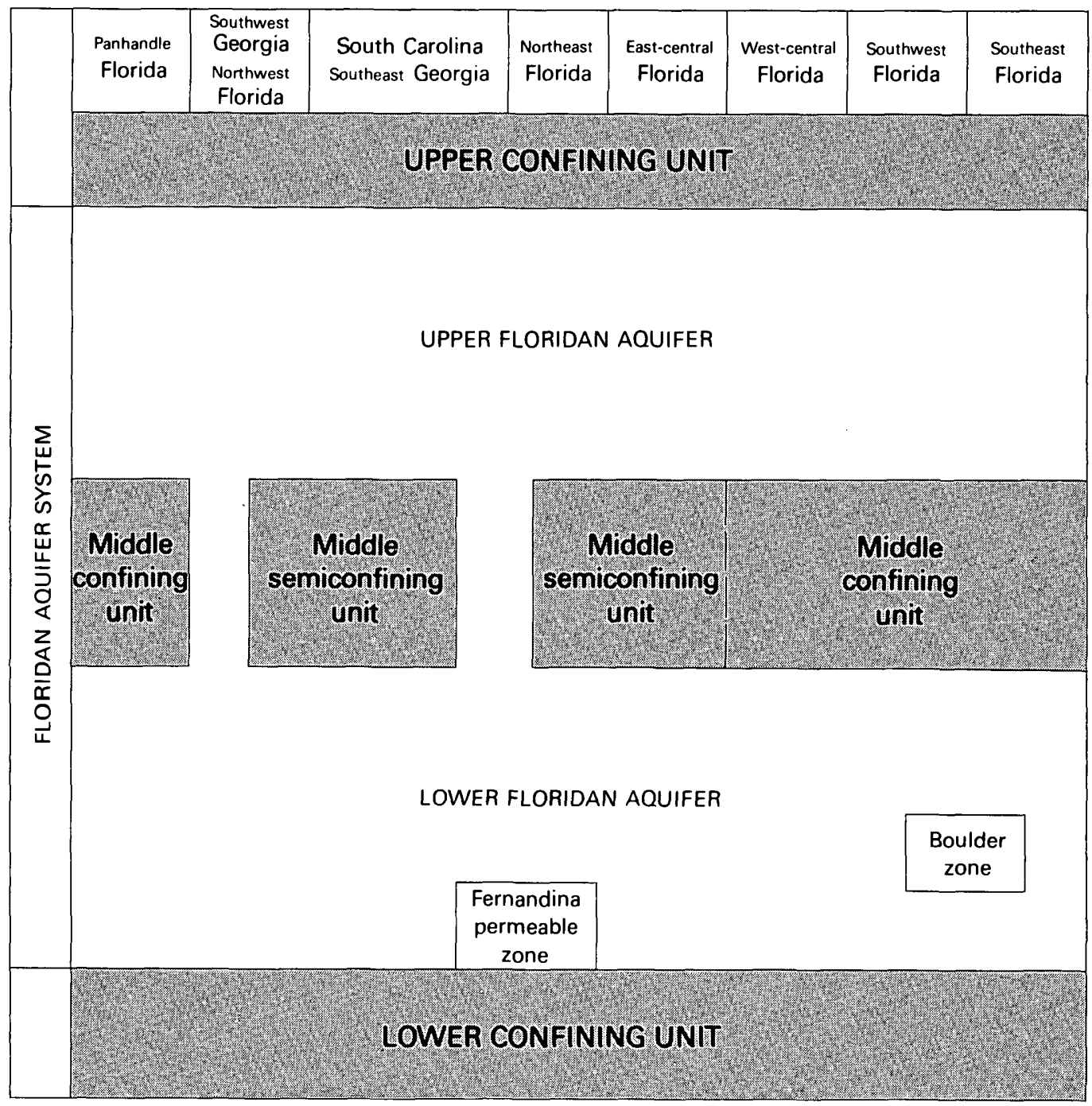


development of permeability. The two classifications use the following similar threefold breakdowns:

\begin{tabular}{|c|c|c|}
\hline \multirow[b]{2}{*}{$\begin{array}{l}\text { Hydrogeologic } \\
\text { control }\end{array}$} & \multicolumn{2}{|c|}{ Flow type } \\
\hline & White (1969) & $\begin{array}{l}\text { LeGrand and } \\
\text { Stringfield (1971) }\end{array}$ \\
\hline $\begin{array}{l}\text { Close network of small frac- } \\
\text { tures and solution openings }\end{array}$ & Diffuse flow & Fine textured \\
\hline $\begin{array}{l}\text { Ground-water flow } \\
\text { predominantly along major } \\
\text { conduits or solution channels; } \\
\text { adjacent rock has comparatively } \\
\text { low permeability }\end{array}$ & Free flow & Coarse textured \\
\hline
\end{tabular}

Confining beds limit flow

Confined flow Reactivated

between aquifers; development

of solution permeability

occurred prior to confining

bed deposition

The "confined" or "reactivated" flow category is not really a separate category because it may be characterized by either "free flow" or "diffuse flow" within a confined zone.

LeGrand and Stringfield (1971) cite the Floridan as an example of a "reactivated" aquifer system. This is certainly true in the downdip areas of coastal Georgia and Florida where several hundred feet of Miocene clays form an effective upper confining unit. However, the area of very large springs in northwest-central Florida (where large solution channels occur in the limestone and flow at or near the orifices is often turbulent) can be characterized as coarse-textured flow or free flow.

Throughout much of the area where the Floridan occurs, the water-bearing openings consist of one or more of the following: (1) openings in loosely cemented fossil hashes (composed of foraminiforal and bryozoan fragments) that are similar to the interstices of sands, (2) mosaics of many fractures and solution-widened joints, and (3) solution cavities ranging in size from less than $1 \mathrm{in}$. to tens of feet or more.

An important question in discussing the hydraulic properties of the Floridan is whether methods of aquifertest analysis developed for porous media are applicable to the fractured, solution-riddled Floridan aquifer system or specifically at what scale do fractures and other openings become sufficiently numerous so that the rock can be considered as a porous media continuum. Bear $(1972$, p. 19-20) defined the smallest volume of rock that can be assigned a single value of any property as the representative elementary volume (REV). An REV should be smaller than the size of the entire flow domain; however, it must be larger than the size of a single pore and it should be large enough to contain a sufficient number of pores to permit the meaningful statistical average required in the continuum concept. Obviously in karst areas where very large cavernous openings occur, the REV will be very large and, in fact, will probably be impossible to define. However, in the more typical Floridan terrain described above (where diffuse flow occurs), the REV could be smaller than the volume of aquifer involved in an aquifer test (that is, less than several ten or hundreds of feet in length).

Field evidence is provided by the response curves of the many Floridan aquifer tests. Plots of drawdown versus time for multiwell aquifer tests of the Floridan generally match the classic nonleaky, leaky, or delayedyield response curves. Many tests in the confined areas are characterized by a Theis (nonleaky) response throughout nearly the entire test duration. The stated assumptions of the Theis and related methods of analysis (homogeneous, isotropic conditions, and so forth) are not met given the nature of the Floridan. However, these assumptions are probably valid on the scale of the typical field test where the response is measured in an observation well hundreds of feet from a pumping well and where the cone of influence is thousands of feet across. At that scale, then, the assumption of a porous media continuum appears reasonable.

In contrast to multiwell tests, hydraulic data from single-well aquifer tests yield questionable transmissivity values. As discussed in the following section, transmissivities estimated from specific capacity data generally bear little relation to transmissivities derived from either multiwell tests or from digital simulations. The reason is that in the vicinity of a pumping well, where the size and spacing of individual openings are important, conduit flow along a few discrete openings predominates. Therefore, the test values probably represent test volumes less than an REV.

The question of whether diffuse or conduit flow predominates is a matter of scale. On a regional scale, diffuse flow predominates and the porous media continuum approach is probably justified. On a local scale (close to springs and pumping wells), discrete openings and conduit flow predominate and the porous media continuum approach is probably invalid. The discussion of transmissivity that follows is concerned with "average regional values" that control diffuse flow on a regional scale. Regional values of transmissivity have been developed primarily for input to digital models for simulating regional ground-water flow in the Floridan aquifer system.

The discussion of transmissivity attempts to relate values from aquifer tests and model-derived values to areal differences in hydrogeology. The discussion of 
storage coefficient relies more on simulation than on aquifer tests. The values of leakage coefficient obtained from the aquifer tests reported here are considered lumped parameters. The discussion of leakage coefficients is based principally on a consideration of the regional geology and simulation results.

\section{TRANSMISSIVITY}

The following discussion of transmissivity is based on 114 aquifer tests, most of which were selected from the hydrologic literature and USGS data files plus three tests conducted during this investigation. The test data are summarized in table 2. The locations of the aquifertest sites and the transmissivity values are shown on plate 2. These tests generally involve only the Upper Floridan aquifer; however, in the updip area where the Upper and Lower Floridan aquifers merge to form a single hydraulic unit, the tests apply to the entire Floridan aquifer system. In the downdip area of peninsular Florida and extreme southeast Georgia, very little is known about the transmissivity of the Lower Floridan aquifer.

\section{AQUIFER TESTS}

Aquifer tests in the Floridan aquifer system are often complicated by highly varying permeability within the tested limestone section and by complex boundary conditions. Other factors such as anisotropy and partial penetration may further complicate the tests.

Examples of permeability characteristics within the Floridan include: (1) detrital units of the Ocala Limestone made of foraminiferal remains and coarse sandsized particles that hydraulically act as sands or gravels; (2) micritic limestone occurring in the Suwannee Limestone of panhandle Florida that acts hydraulically as a silt or clay; (3) networks of many small solution openings along joints or bedding planes that on a gross scale provide a uniform distribution of permeability; however, locally the networks are characterized by discrete fracture flow; and (4) a few large cavernous openings developed in recent karstic or paleokarst areas.

For the first three examples cited, the probability exists that the aquifer will act as a single-porosity continuum on a gross scale. Generally aquifer tests in the Floridan outside the karstic terrains yield response curves that match classical type curves (Theis, 1935; Hantush, 1960; Boulton, 1963; and others) very well. Where such curve matches are obtained, the assumption of a porous media is probably valid within the area of influence of the test.

For karstic terrains where flow is predominantly through a few discrete openings or conduits, a porous- media analytical approach is not theoretically justified. Analytical methods that assume flow through discrete fractures as proposed by Streltsova (1976) or methods that assume flow in porous media combined with flow through fractures (the double-porosity model) as described by Barenblatt and others (1960) are presumably more applicable. However, choosing a method for analysis of karstic aquifer-test data to date has been an academic concern because the logistical problems of conducting tests in karst areas have been too difficult to overcome.

Boundary conditions within the area of influence require careful consideration and may rule out the possibility of obtaining meaningful results from an aquifer test of the Floridan. Recharging boundaries include: (1) very large solution cavities/conduits and (2) streams and sinkholes in the unconfined and semiconfined areas. Discharging boundaries include: (1) facies change from permeable limestone to micritic limestone or limestone to clastic beds within the area of influence, (2) faults juxtaposing clastic rock against carbonate rock, or (3) significant reductions in solutioning.

Aquifer-test response is dependent upon the nature of the Floridan's permeability, local boundary conditions as discussed above, and the characteristics of the associated confining beds. Boundary conditions caused by conduits, streams, and sinkholes tend to be highly localized. However, facies changes that affect the permeability and thickness of the Upper Floridan and the overlying confining unit tend to occur (in gross fashion) on a more regional basis. Thus, large areas tend to be characterized by similar degrees of confinement, aquifer thickness, and solution development.

Assuming that the permeability distribution is sufficiently uniform at a given site for application of porousmedia techniques, the selection of the appropriate method for analyzing the response curves is largely dependent on the nature and thickness of the overlying confining bed. Where the aquifer is thickly confined or where thinly confined by clays, nonleaky or leaky artesian responses have been observed. True unconfined conditions rarely occur in the Floridan. Within the Floridan's outcrop area, the limestone is invariably covered by sandy to clayey residuum. Delayed-yield responses have been observed where the residuum is thin and sandy, and leaky to nonleaky responses observed where clayey residuum exists.

Four aquifer tests are described here: Nilo Plantation test, Doctortown test, Dunnellon test, and Green Swamp test. The tests illustrate aquifer response under different hydrogeologic conditions as follows:

1. The Nilo Plantation test represents conditions in the updip outcrop area of Georgia where the Upper Floridan is thin and overlain by a thin cover 
GROUND WATER OF THE FLORIDAN AQUIFER SYSTEM

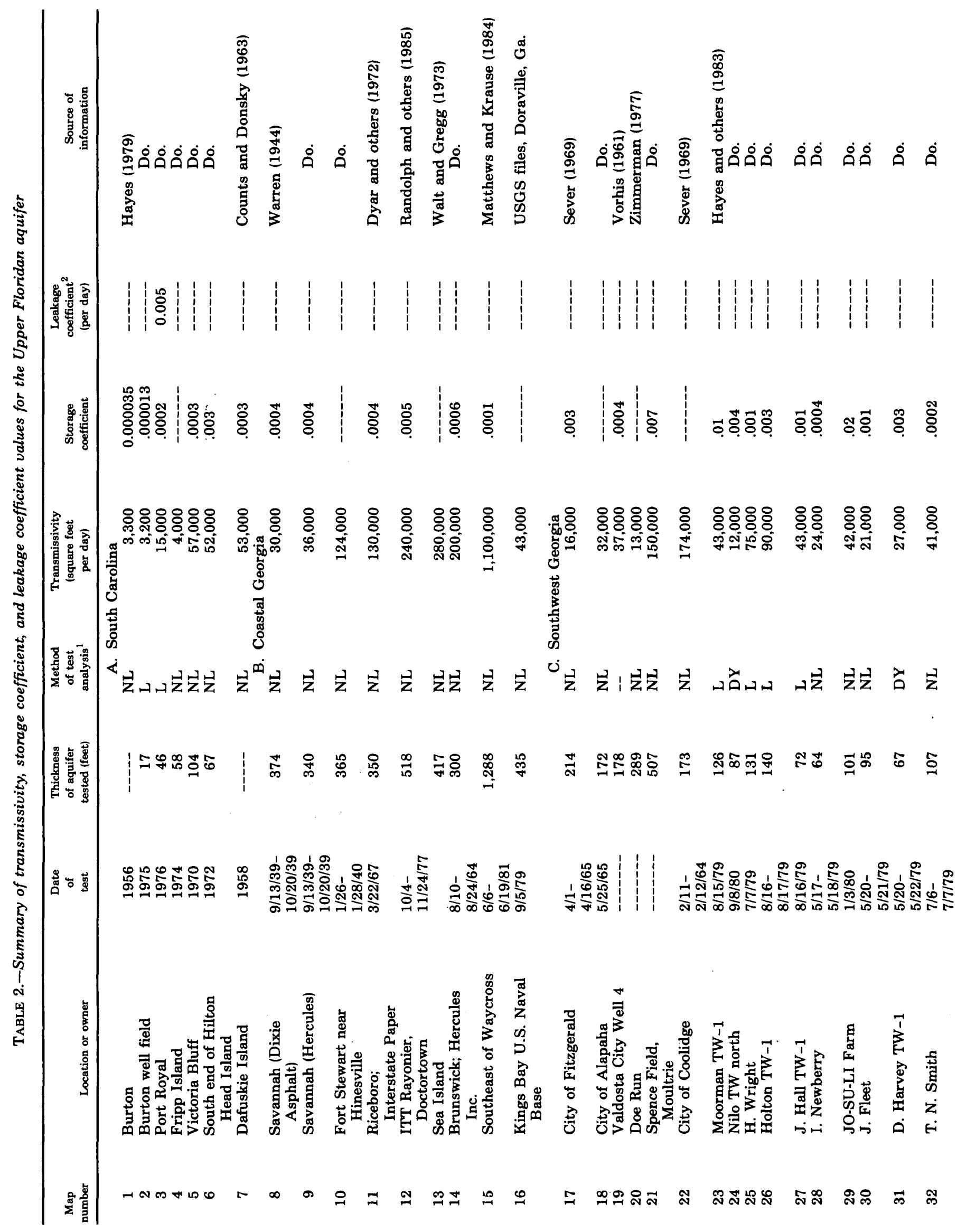




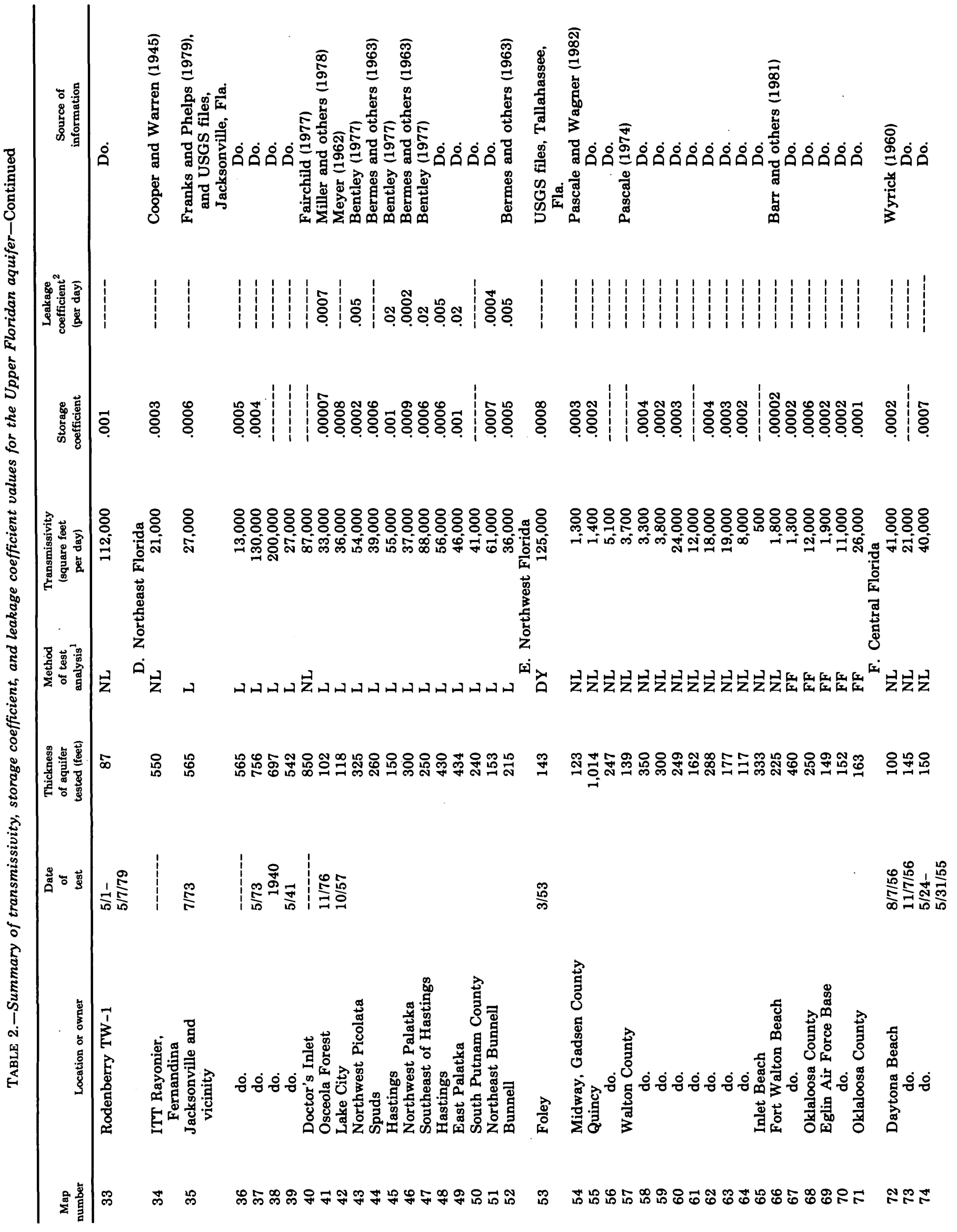


GROUND WATER OF THE FLORIDAN AQUIFER SYSTEM

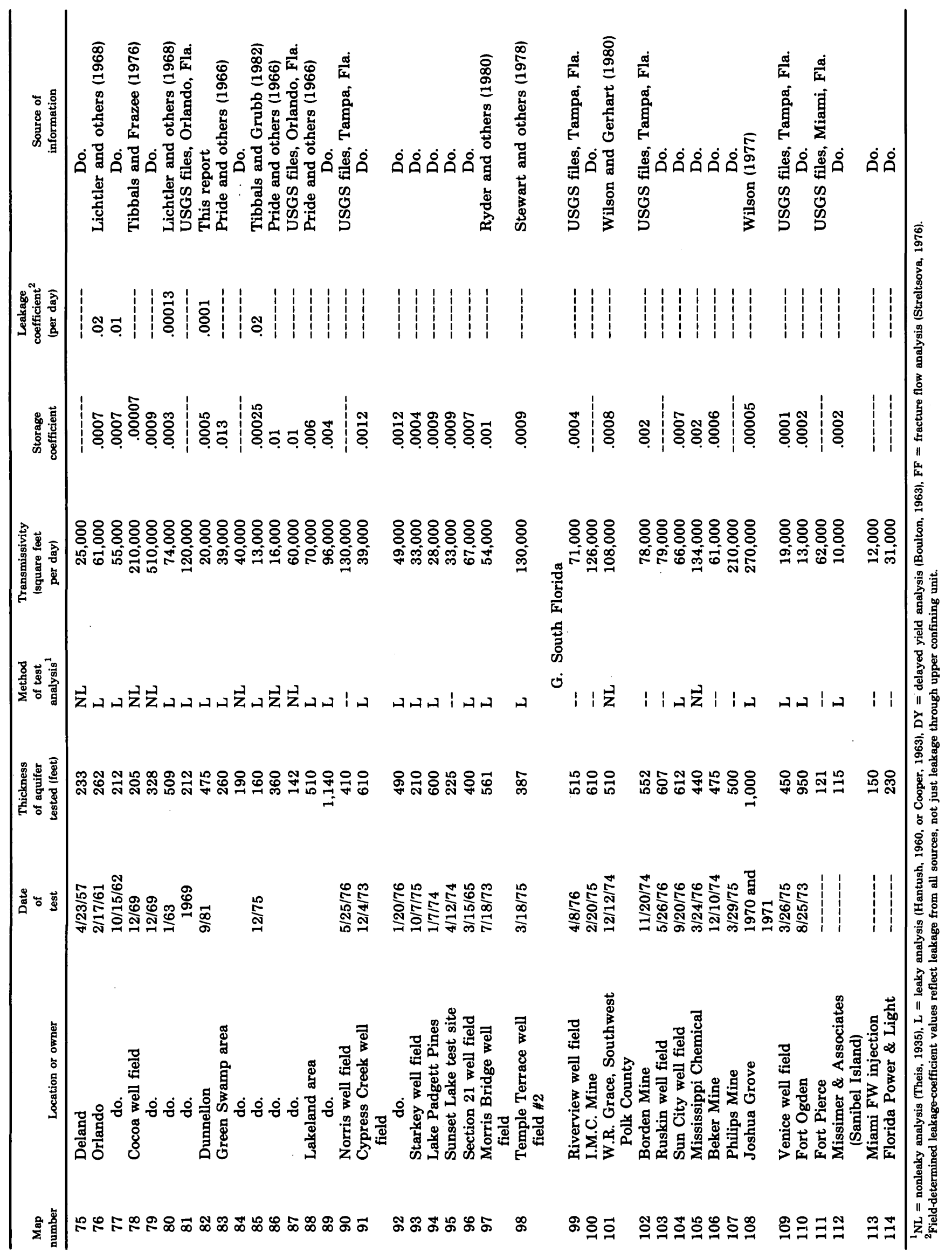


of sandy residuum. Test results indicate a delayed-yield response.

2. The Doctortown test is an example of conditions further downdip in coastal Georgia and northeast Florida where the aquifer is several hundred feet thick and overlain by a thick, clayey confining unit. Testing the thick, highly transmissive carbonate section at this site yielded a nonleaky response.

3. The Dunnellon and Green Swamp tests represent conditions in central and northern Florida where the Upper Floridan is semiconfined and contains alternating beds of lesser and greater permeability effectively forming a leaky, multilayered system. The Dunnellon test shows the response to pumping the entire thickness of aquifer in an area where the Floridan is about $500 \mathrm{ft}$ thick. The Green Swamp test is an example of the response to pumping a single permeable unit within a multilayered sequence. At both test sites, a leaky-artesian response was observed.

No aquifer-test examples are presented for the karstic area of central and northwest peninsular Florida. Within this area the Upper Floridan is either unconfined or semiconfined and cavernous development is extensive, especially in the vicinity of the major springs. Conducting an aquifer test in this area is virtually impossible. A major logistical problem is the need to pump several thousand gallons per minute to stress the aquifer measurably and the consequent need to remove pumped water from the site to prevent recycling. In addition, conduit flow and complex boundary conditions prevent test analysis using porous-media techniques. However, flow-net analyses using large springs as the discharge control have been successfully used to determine transmissivity. Faulkner (1973, p. 93-98) determined an average transmissivity of $2,000,000 \mathrm{ft}^{2} / \mathrm{d}$ for the Silver Springs area and Sinclair (1978) determined an average transmissivity of $1,200,000 \mathrm{ft}^{2} / \mathrm{d}$ for the Weeki Wachee Springs area.

\section{NILO PLANTATION TEST}

The Nilo aquifer-test site is in southwest Georgia about $7 \mathrm{mi}$ southwest of the city of Albany (site 24 on pl. 2). The site is within the updip outcrop area of southwest Georgia referred to as the Dougherty Plain and locally characterized by sinkhole topography. Limestone is commonly exposed in stream channels and elsewhere occurs near the surface. In this area of southwest Georgia, hydrogeologic conditions are variable; however, the Upper Floridan aquifer and overlying confining unit are characteristically thin. Except for stream cuts, the limestone is almost always covered by $30-60 \mathrm{ft}$ of residuum. Thus, the Nilo test provided an opportunity to obtain aquifer coefficients in the outcrop area where the aquifer is thin although locally highly transmissive (due to solution features).

At the Nilo site, $165 \mathrm{ft}$ of white, friable, fossiliferous limestone is overlàn by $50 \mathrm{ft}$ of residuum (largely sand with some clay). The test involved a pumping well (used for a center-pivot irrigation system) and a single observation well (TW-2), located $190 \mathrm{ft}$ away. Both wells were cased in the residuum and left open to $87 \mathrm{ft}$ of the limestone aquifer (about 50 percent penetration).

The test was conducted on September 8-9, 1980, by L. Hayes, W. Meeks, and G. Mitchell of the USGS. The irrigation well was pumped at a rate of $1,700 \mathrm{gal} / \mathrm{min}$ for 1,000 min during which water-level measurements were made in well TW-2.

Figure 2 shows a plot of drawdown versus time for observation well TW-2. Data for the first $10 \mathrm{~min}$ are not shown because the pumping rate had not yet stabilized at a constant rate of $1,700 \mathrm{gal} / \mathrm{min}$. The timedrawdown curve displays a Theis (nonleaky) response for 10-50 min and then gradually departs below the Theis curve. This later response could be interpreted as delayed yield from storage, assuming that the sandy residuum and limestone act together as a single unconfined aquifer. Alternately the response could be considered as artesian with the residuum acting as a leaky confining bed. Because the residuum is mostly sand and the limestone is thin, the transmissivity of the two units is probably comparable. Hence the assumption of a single unconfined aquifer with delayed yield seems more valid. Using the match point shown in figure 2, the calculated transmissivity is about $12,000 \mathrm{ft}^{2} / \mathrm{d}$. The storage coefficient of 0.004 is intermediate between that of confined and unconfined aquifers-presumably this value would be larger if the test proceeded until delayed yield was complete.

\section{DOCTORTOWN TEST}

This aquifer test involved a large reduction in pumping at the ITT Rayonier Inc., plant at Doctortown, Ga. (site 12 on pl. 2). The hydrogeologic conditions at the site typify much of the coastal area of southeast Georgia and northeast Florida, namely a thick, highly transmissive section of the Upper Floridan overlain by a thick, clayey confining unit. A detailed description of the data collection and test analysis is presented by Randolph and others (1985).

At the site, the Upper Floridan is overlain by almost $500 \mathrm{ft}$ of Miocene clay with interbedded sand and silt that constitutes the upper confining unit. The test involved 11 supply wells, all of which are open to the full thickness of the Upper Floridan aquifer (500 to about 


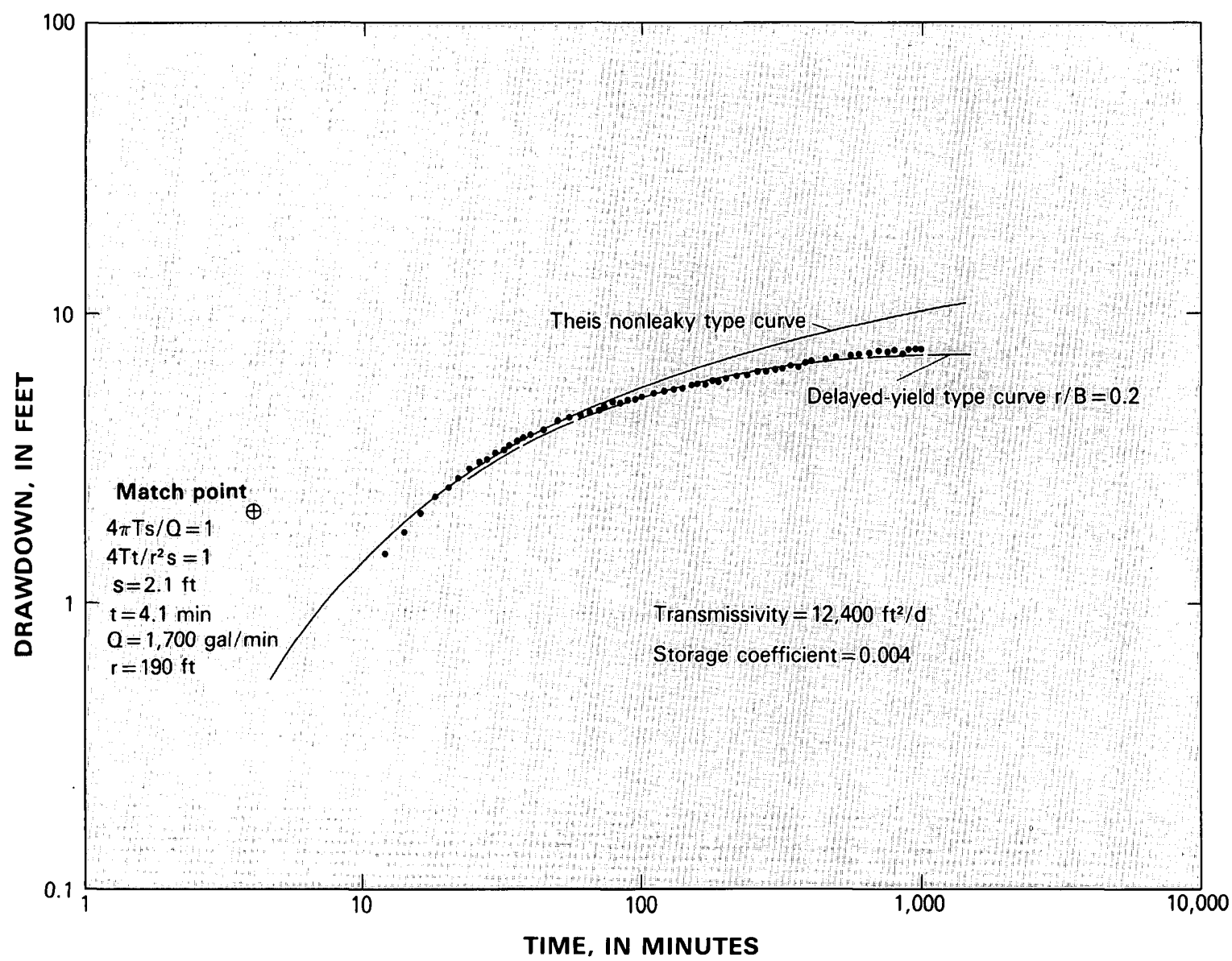

FIGURE 2.-Logarithmic plot of drawdown versus time for observation well TW-2, Nilo Plantation aquifer test.

$1,000 \mathrm{ft}$ below land surface) and part of the middle confining unit.

Figure 3 shows the location of the center of pumping at Doctortown and the cone of depression produced by an average withdrawal of 70-75 Mgal/d. Response to the October 1977 shutdown was observed in four wells (Mears 1 and 2, Johnson, USGS TW-3) tapping the Upper Floridan located about 5-14 $\mathrm{mi}$ from the pumping center as shown in figure 3 .

The shutdown was phased in during October 1-4, 1977 , with a decrease in pumpage from about $72 \mathrm{Mgal} / \mathrm{d}$ to about $6 \mathrm{Mgal} / \mathrm{d}$. For the analysis of the recovery period (October 4 to December 29, 1977), the average decline in pumping rate is considered to be $66 \mathrm{Mgal} / \mathrm{d}$. Because the shutdown occurred over several days, the early data are not useful for the analysis.

Figure 4 shows plots of recovery versus $r^{2} / t$ for the four observation wells and the superposed Theis (nonleaky) type curve. The later data either match or closely approach the Theis curve. Using the match point shown, transmissivity is calculated to be $240,000 \mathrm{ft}^{2} / \mathrm{d}$ and the storage coefficient is $5 \times 10^{-4}$.

The Doctortown test was successful in evaluating a highly transmissive section of the Upper Floridan primarily because a very large stress was imparted to the aquifer by the $66 \mathrm{Mgal} / \mathrm{d}$ decrease in pumpage. As a result, analyzable responses were obtained in observation wells located up to $15 \mathrm{mi}$ from the center of pumping. A Theis (nonleaky) response was anticipated because the field hydrogeologic conditions (clay overlying highly transmissive limestone) suggested that leakage would be minimal. The fact that the mass plot of recovery versus $r^{2} / t$ for the four observation wells closely follows the Theis type curve for late times suggests that isotropic/homogeneous conditions are approached at the scale of the test.

Anisotropy in the Upper Floridan was investigated by Randolph and others (1985) using the Doctortown test data and a local aquifer test in the area. They used transmissivity tensor analysis to compute directional transmissivity values of $370,000 \mathrm{ft}^{2} / \mathrm{d}$ and $180,000 \mathrm{ft}^{2} / \mathrm{d}$ for the test described here. The computed ratio of anisotropy is thus about 2:1 and is incompatible with the occurrence of large directional variations in aquifer transmissivity due to faults, major solution channels, or facies changes within the 15 -mi radius observed. The 


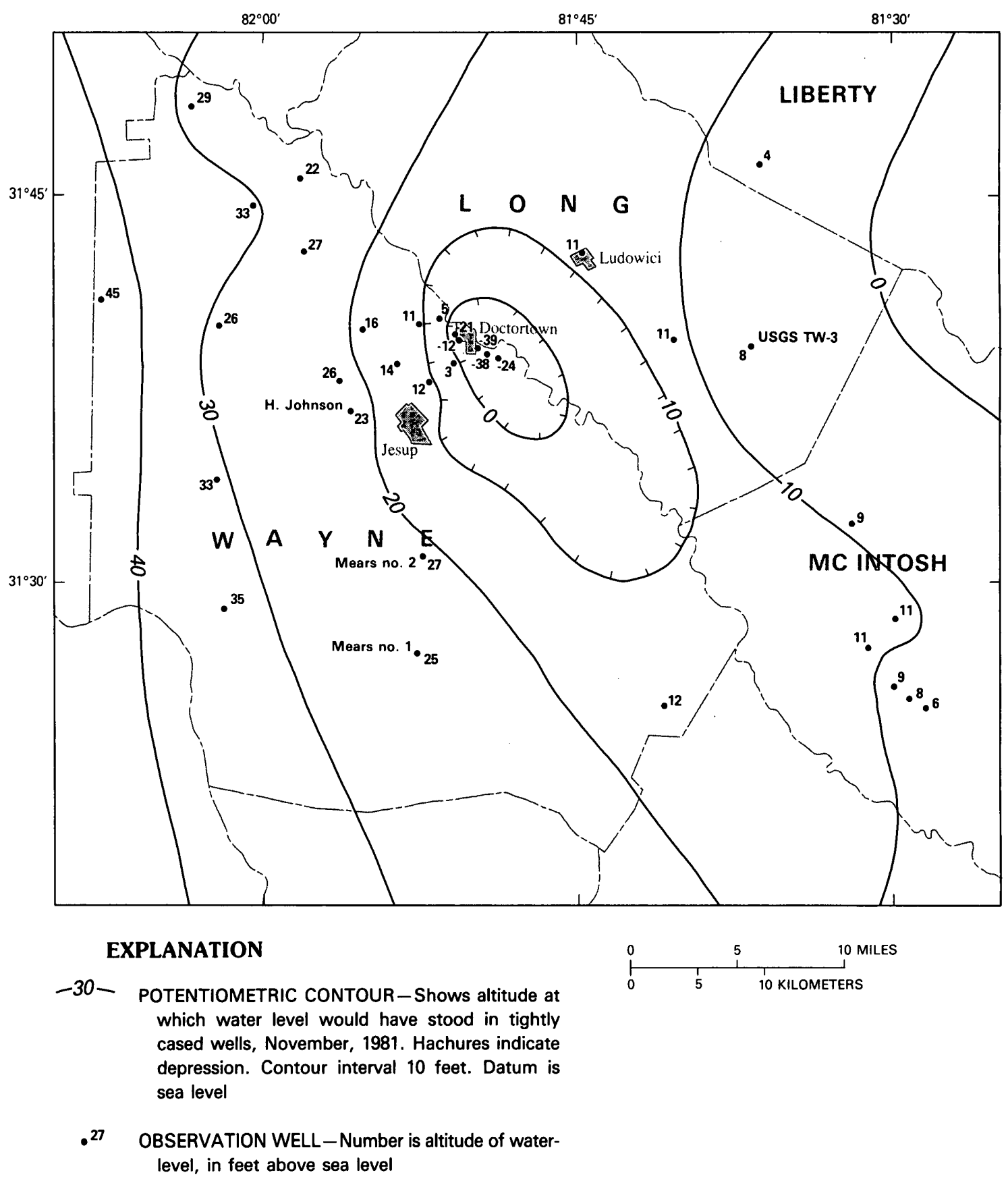

FIGURE 3.-Potentiometric surface of the Upper Floridan aquifer and location of observation wells, Doctortown, Ga.

values of transmissivity required to calibrate the regional flow model in this area $\left(200,000-300,000 \mathrm{ft}^{2} / \mathrm{d}\right)$ are consistent with the aquifer-test values.

\section{DUNNELLON TEST}

The Dunnellon aquifer-test site is in west-central Florida about 10 mi northeast of the town of Dunnellon (site 82 on pl. 2). The primary purpose of the test was to determine the hydraulic characteristics of the Upper
Floridan aquifer in one of its thinner known areas of occurrence in peninsular Florida-on the Ocala uplift where the generally permeable Ocala Limestone is missing. The occurrence of a localized "high" on the potentiometric surface and associated steep gradients suggested substantially lower transmissivity than elsewhere in central Florida (pl. 2).

At the site, the Floridan is overlain by a surficial sand aquifer (0-135 $\mathrm{ft}$ ) and an upper confining unit (135-214 ft) consisting of sand and clay beds (Hawthorn 


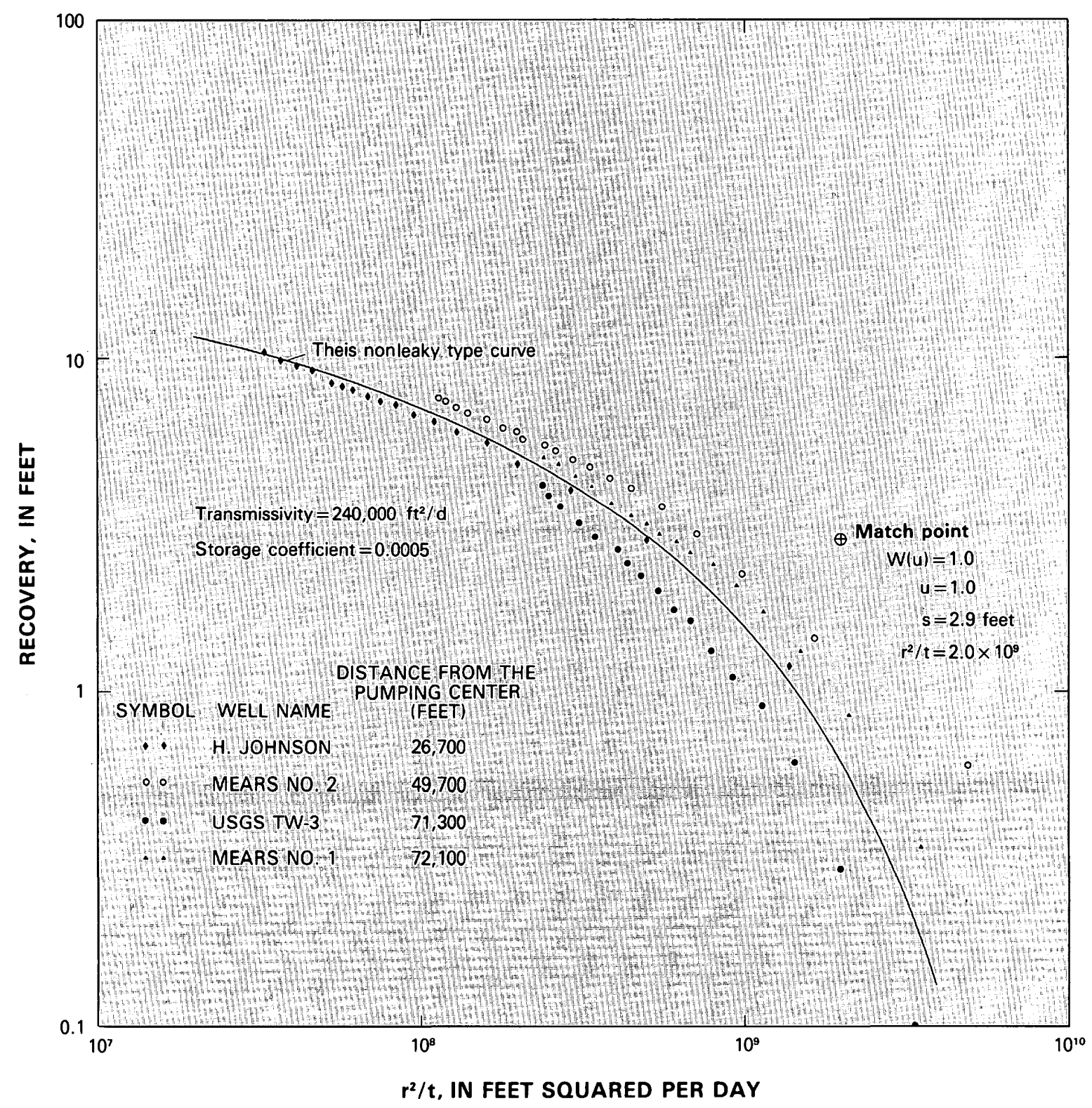

FIGURE 4.-Logarithmic plots of recovery versus $\mathrm{r}^{2} / \mathrm{t}$ for observation wells, Doctortown aquifer test (Modified from Randolph and others (1985, fig. 4)).

Formation). The Upper Floridan extends from 214-706 $\mathrm{ft}$ and consists of dolomite and dolomitic limestone (J. D. Fretwell, U.S. Geological Survey, written commun., 1982). The test involved a pumping well and an observation well $284 \mathrm{ft}$ away, both of which fully penetrate the Upper Floridan (completed as open hole from $300-780 \mathrm{ft}$ ). In addition, two shallow wells in the surficial aquifer were used for observation.

The test was conducted on September 14-17, 1981, by J. D. Fretwell who provided the test data and analysis. A constant discharge of $2,150 \mathrm{gal} / \mathrm{min}$ was maintained from the pumping well, except for the first $5 \mathrm{~min}$ during which the discharge was $1,500-1,600 \mathrm{gal} / \mathrm{min}$. Drawdowns were measured in the three observation wells throughout the 72-hr pumping period and during recovery. However, only data obtained from the observation well tapping the Upper Floridan were used for analysis. The data from the two shallow wells were not used because of uncertain construction of one well and spillage of discharge water near the other well.

Figure 5 shows a plot of drawdown versus time for the observation well tapping the Upper Floridan. The plot closely matches the Theis (nonleaky) type curve except for very early and very late times. J. D. Fretwell 


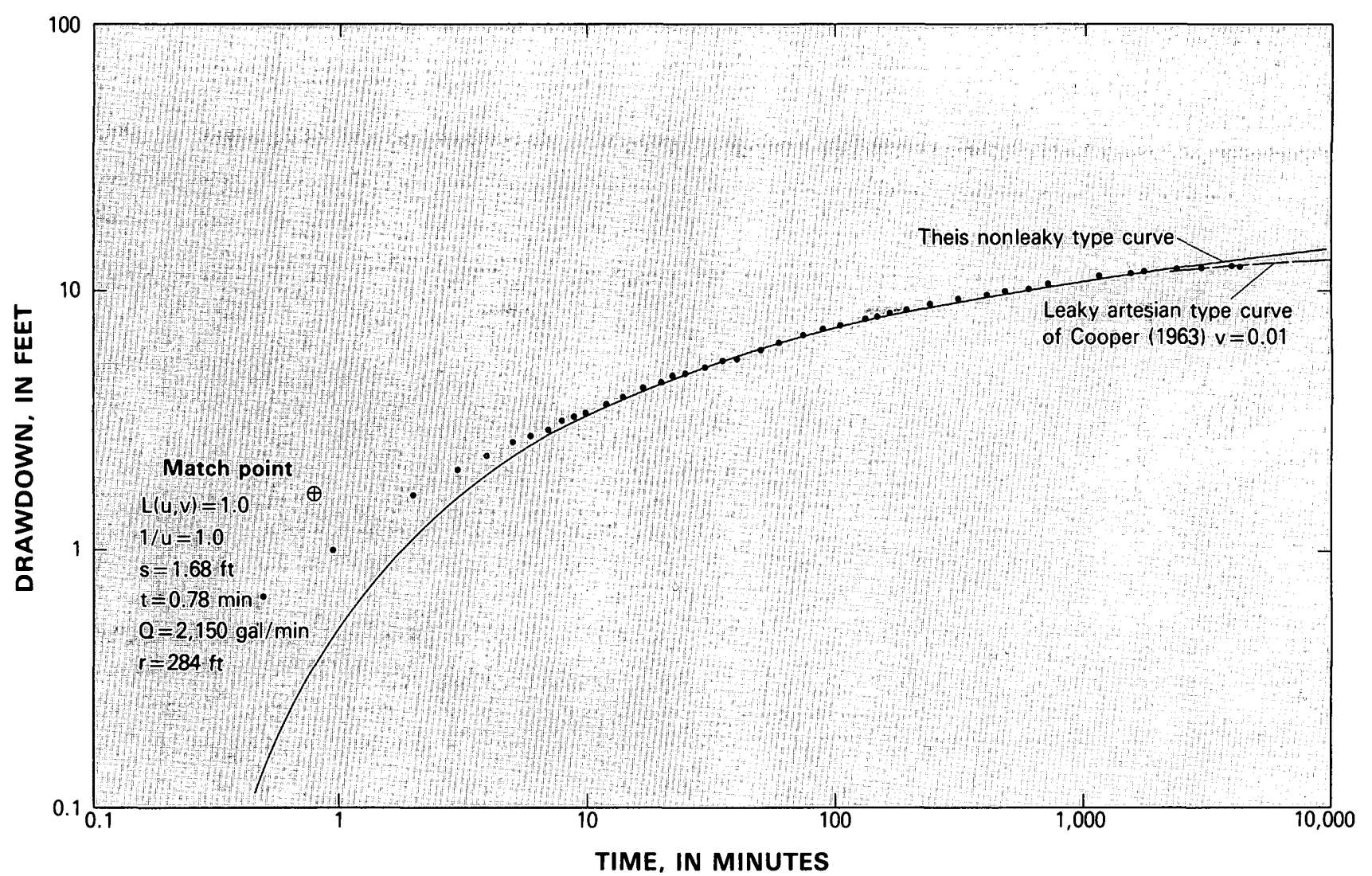

Figure 5.-Logarithmic plot of drawdown versus time for Tidewater-2 observation well, Dunnellon aquifer test.

(written commun., 1982) concluded that, if the very early data (first $10 \mathrm{~min}$ ) are ignored, the data are most logically analyzed as a leaky confined aquifer with no change in storage in the confining unit (Hantush and Jacob, 1955, and Cooper, 1963). The match point of a Cooper type curve with $V$ value of 0.01 provides transmissivity of $20,000 \mathrm{ft}^{2} / \mathrm{d}$; storage coefficient of $5 \times 10^{-4}$; and leakage coefficient of $1.0 \times 10^{-4}$ per day.

\section{GREEN SWAMP TEST}

The Green Swamp test site is located in southwest Lake County in central Florida (site 85 on pl. 2). The site is within the major potentiometric surface "high" of the Upper Floridan aquifer in peninsular Florida. The aquifer test (Tibbals and Grubb, 1982, p. 2) was conducted "to determine hydraulic properties of the Floridan aquifer and overlying confining materials in an area where additional downward leakage, or recharge, can be induced."

At the site, the Upper Floridan is overlain by $40 \mathrm{ft}$ of fine sand. The test well was constructed as an uncased hole open to the Upper Floridan from 66-200 ft.
Four observation wells were constructed similarly in the Upper Floridan, and eight observation wells were installed at various depths in the surficial deposits. The Upper Floridan at the site consists of about $60 \mathrm{ft}$ of highly permeable limestone underlain by at least $100 \mathrm{ft}$ of less-permeable clayey limestone. Thus, the Green Swamp test involved a permeable limestone aquifer overlain by a very leaky confining unit and underlain by a confining unit of clayey limestone. The transmissivity that was determined, therefore, represents the $60 \mathrm{ft}$ of permeable limestone.

The test was conducted December 15-16, 1975, with a constant pumping rate of $1,040 \mathrm{gal} / \mathrm{min}$ for $35 \mathrm{hr}$. Drawdown was measured in the 12 observations wells.

Tibbals and Grubb (1982) analyzed the drawdown data using both the transient-leakage artesian method of Hantush (1960) and the steady-state leakage method of Cooper (1963). Figure 6 shows plots of drawdown versus $t / \mathbf{r}^{2}$ for the four Upper Floridan observation wells. The match-point coordinates for the two solutions are identical. The calculated transmissivity is $13,000 \mathrm{ft}^{2} / \mathrm{d}$ and the storage coefficient is $2.5 \times 10^{-4}$. The leakage coefficient of the overlying confining bed is about 0.02 per day. Tibbals and Grubb (1982, p. 14) noted that these calculated values are based on two assumptions: (1) all 


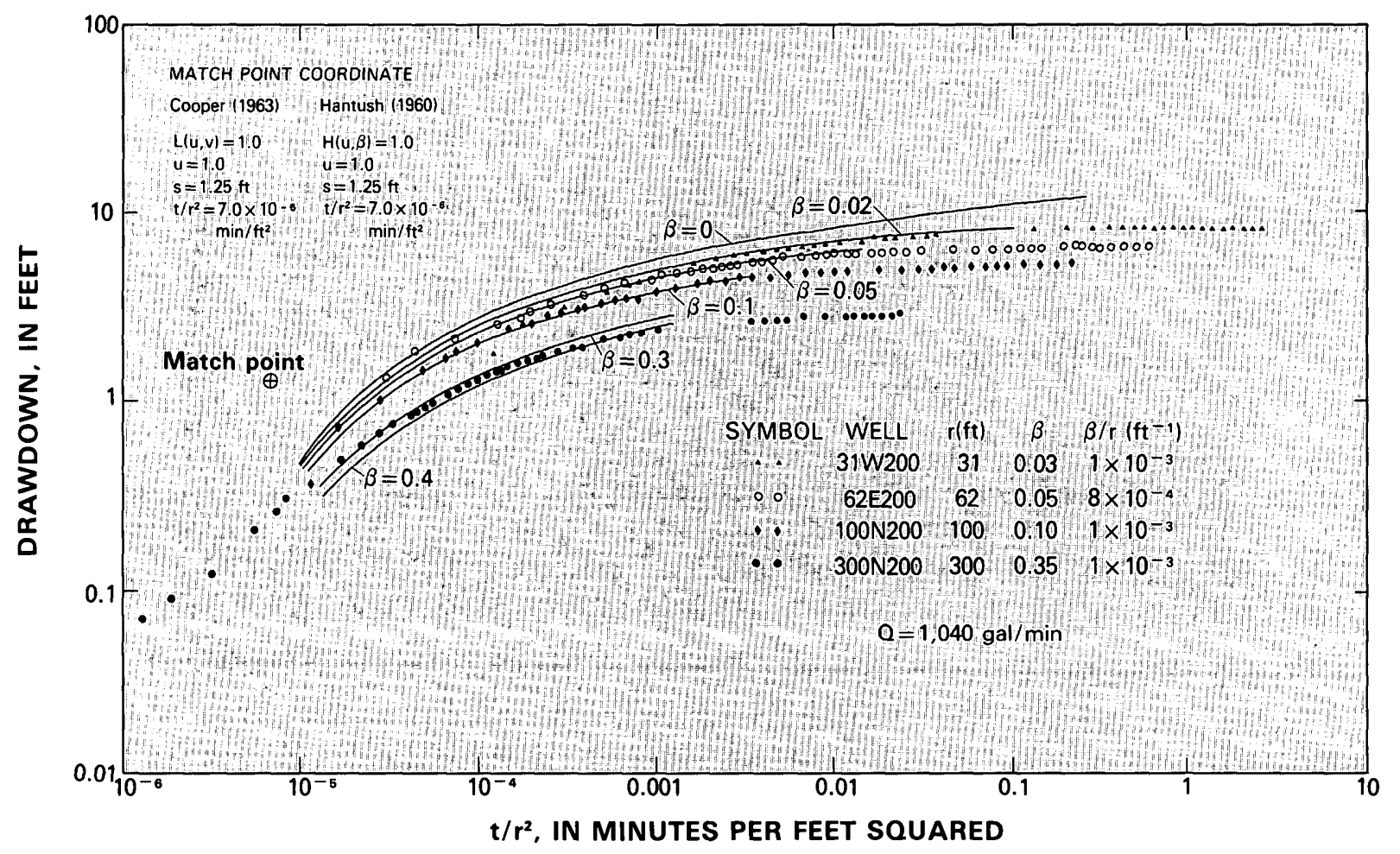

\footnotetext{
Values from the steady-leakage solution of Cooper (1963)

Transmissivity $=13,000 \mathrm{ft}^{2} / \mathrm{d}$

Storage coefficient $=2.5 \times 10^{-4}$

Leakage coefficient $\left(K^{1} / b^{1}\right)=2.5 \times 10^{-2} / d$
}
Values from the transient-leakage solution of Hantush (1960)
Transmissivity $=13,000 \mathrm{ft}^{2} / \mathrm{d}$
Storage coefficient $=2.5 \times 10^{-4}$

FIGURE 6.-Logarithmic plots of drawdown versus $t / r^{2}$ for observation wells, Green Swamp aquifer test (modified from Tibbals and Grubb (1982)).

\begin{abstract}
leakage takes place through the overlying confining unit and (2) the head remains constant in the overlying surficial aquifer. They further stated (p. 14) that the first assumption may not be valid because, during the test, the potential existed for upward leakage into the pumped zone from the clayey limestone below; therefore, the leakage coefficient determined may incorporate leakage from below as well as from above. The second assumption was not met because measurable drawdown occurred in the surficial aquifer. As noted by Tibbals and Grubb (1982, p. 14), the effect of this drawdown is to yield slightly higher values of drawdown (s) and $t / r^{2}$ at the match point than if the surficial-aquifer head remained constant.
\end{abstract}

\section{SPECIFIC-CAPACITY DATA}

Transmissivity was estimated from specific-capacity data for about 200 wells tapping the Upper Floridan aquifer using a hand calculator programmed to solve the Theis (1935) equation (H. B. Counts, U.S. Geological Survey, written commun., 1979). Figure 7 shows transmissivities calculated from the programmed Theis equation with transmissivities from the calibrated regional model at the same locations, respectively. The plot shows that only a minimal relation exists between transmissivities calculated from specific-capacity data and the model-derived transmissivities. Most values of transmissivity from specific-capacity data are generally much lower than the values required to calibrate the digital models because of well loss and the dominant effect of aquifer material near wells.

For comparison purposes, values of specific capacity are sometimes adjusted by dividing by depth of well penetration (see for example, Walton, 1962). However, the uppermost part of the Floridan is generally the most transmissive-especially where the aquifer is 


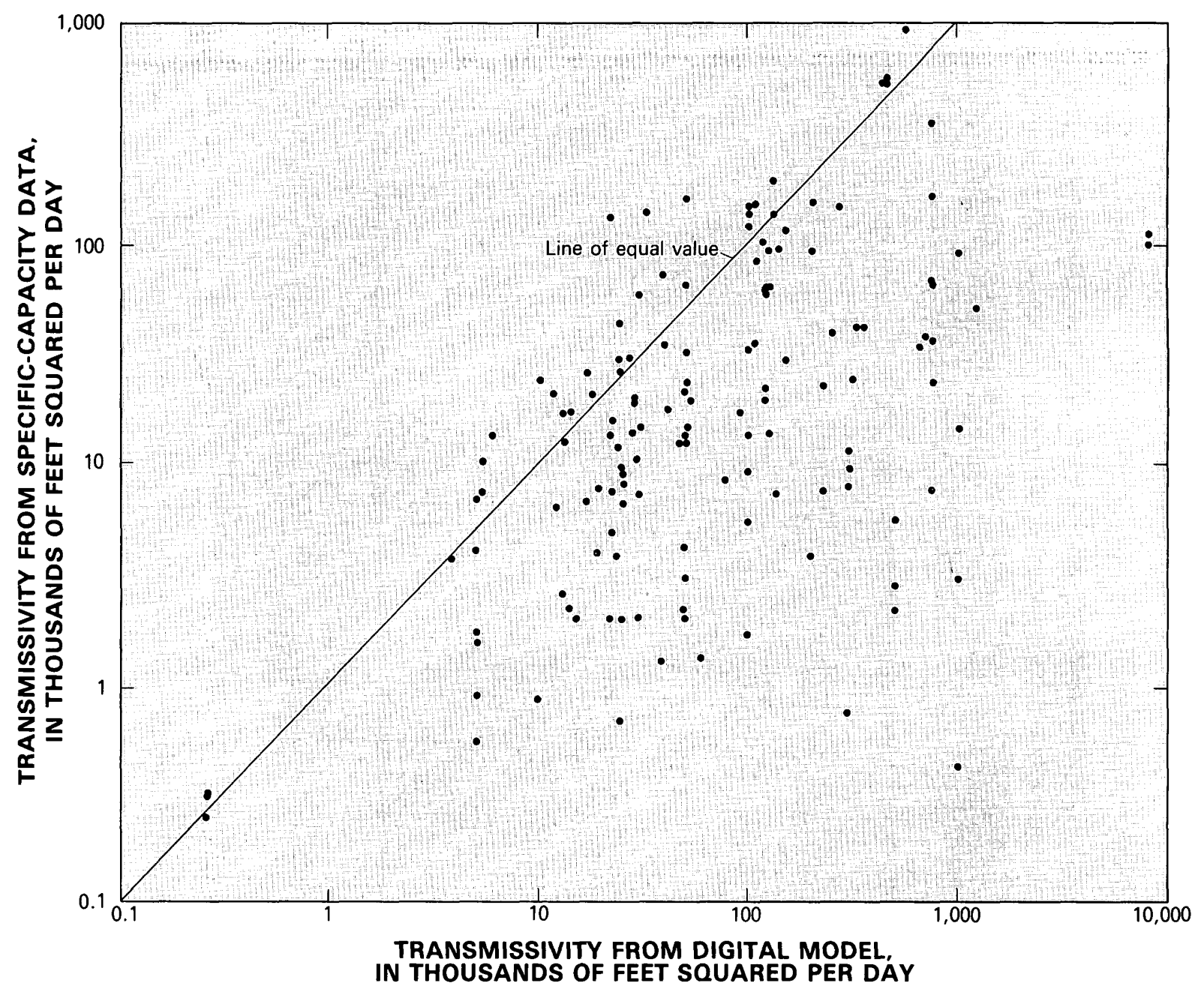

FIGURE 7.-Comparison of transmissivities estimated from specific capacity with model-derived transmissivities.

semiconfined and karstic. Thus, comparing the specificcapacity per foot of penetration of shallow wells with deep wells has little meaning. In preparing figure 7 , we arbitrarily decided to include all wells with more than 25-percent aquifer penetration.

Figure 8 compares transmissivities determined from multiwell aquifer tests (in which the pumping the well penetrates at least 25 percent of aquifer) with modelderived transmissivities at the same locations, respectively. The relationship between transmissivity values obtained from aquifer tests and from simulation is considerably better than the relationship between transmissivities from specific-capacity data and from simulation. A least-squares regression line fitted to these data shows that transmissivity from aquifer tests, like transmissivity from specific-capacity data, is in general lower than transmissivity from simulation, but not a great deal lower. The line of regression is not far from the line of equal value.

Specific-capacity data are dominated by two effects: (1) the size and spacing of water-bearing openings in the rock adjacent to the well bore and (2) well losses due to turbulent flow within the well bore or immediately adjacent to it. These two factors are probably major reasons for transmissivity values from specific-capacity data being lower than model-derived values. Specific capacity is thus not a particularly good basis from which to estimate transmissivity in most parts of the Floridan aquifer system. These problems are minimized on the scale of multiwell aquifer tests. As previously discussed, scale is apparently a key to understanding the hydraulics of the Floridan. Transmissivities obtained from aquifer tests (where pumping and observation wells are hundreds of feet apart) more nearly 


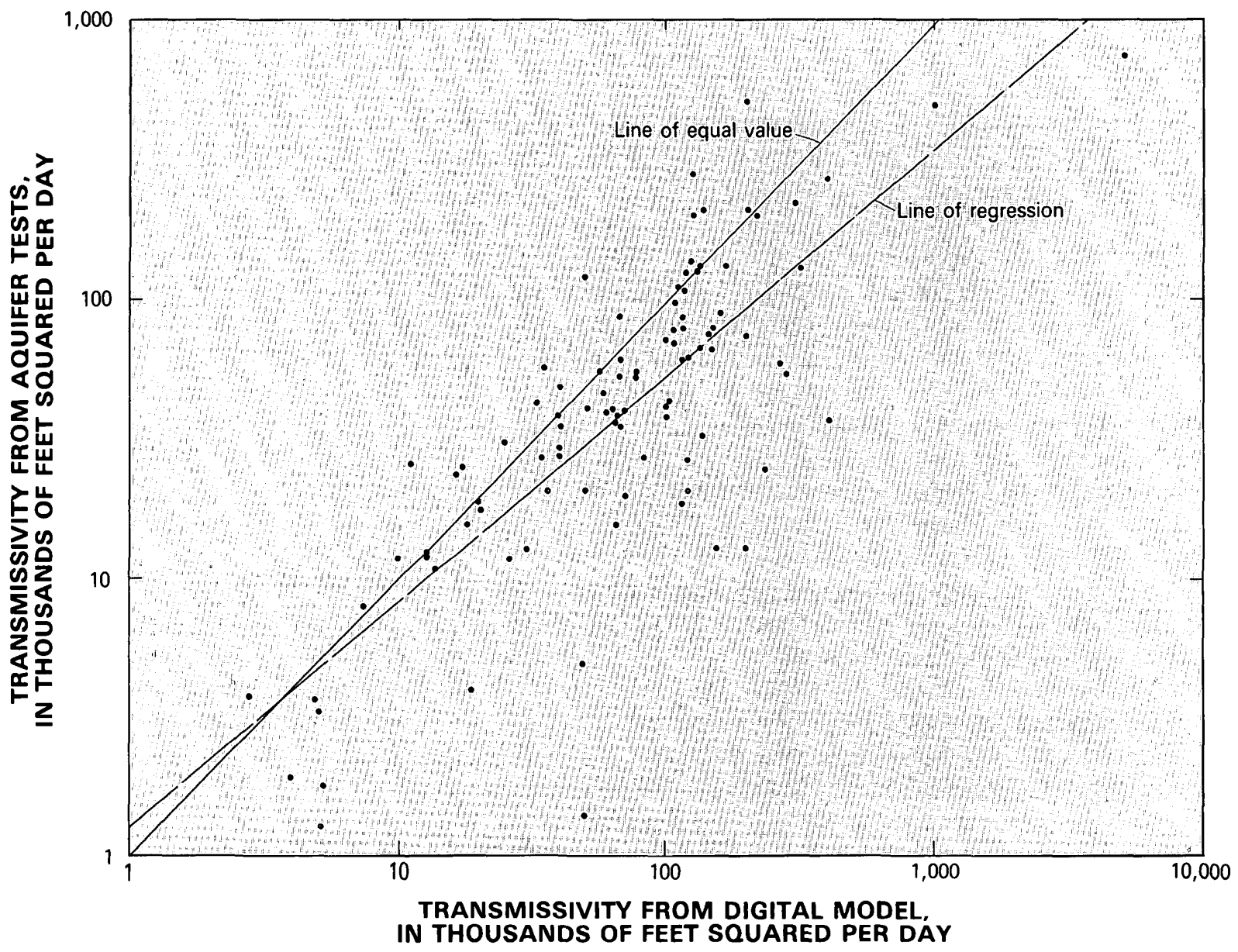

FIGURE 8.-Comparison of transmissivities from multiwell aquifer tests with model-derived transmissivities.

approach the transmissivities that control flow on a regional basis.

\section{AREAL DISTRIBUTION OF TRANSMISSIVITY}

UPPER FLORIDAN AQUIFER

The areal distribution of transmissivity of the Upper Floridan aquifer is shown on plate 2. The map portrays the most probable ranges of transmissivity based on the aquifer-test values, model-derived values, and geology. At sites where test wells are fully penetrating, the field-test values and the model-derived values generally are in good agreement. However, where test wells do not fully penetrate the Upper Floridan, the field values are generally less than model-derived values.

Finite-difference modeling requires that the aquifer system be divided into blocks in which the hydraulic properties are assumed to be uniform. Each block in the regional model grid represents an 8-mi by 8 -mi area.
Thus, the model-derived transmissivities are average values for a $64-\mathrm{mi}^{2}$ area and do not reflect the variations in transmissivity that may occur locally due to solution features in the carbonate rock-variations which may produce transmissivity changes of an order of magnitude or more within a few miles. The field-test values in part reflect these changes and thus differences among transmissivity values from closely spaced test sites can be seen on plate 2 . The contrast between fieldtest values and model-derived values is evident in the Jacksonville area. There the model suggests a range of transmissivity from 100,000-250,000 $\mathrm{ft}^{2} / \mathrm{d}$. However, field values for six fully penetrating well tests range from $13,000-200,000 \mathrm{ft}^{2} / \mathrm{d}$.

The field-test data tend to be concentrated in the areas of heavy withdrawals. Where ground-water development has been little or none, the transmissivity estimates used to prepare plate 2 are based primarily on model calibration. This includes the area of very large spring flows in central and northwest Florida. Within 
this area, simulation indicates transmissivities ranging from $250,000 \mathrm{ft}^{2} / \mathrm{d}$ to as much as $10,000,000 \mathrm{ft}^{2} / \mathrm{d}$. As discussed in the previous section, performing aquifer tests in the highly transmissive, unconfined, karstic areas of the Upper Floridan aquifer is virtually impossible. However, flow net analyses in the vicinity of major springs have yielded average transmissivities ranging from about 1,000,000-2,000,000 $\mathrm{ft}^{2} / \mathrm{d}$.

A qualitative assessment of the reliability of the transmissivity map was made based on the availability of field-test data and the sensitivity of the regional flow model to transmissivity. As indicated on the inset map on plate 2, transmissivities shown for those areas where aquifer-test data are available and where the model is sensitive to the transmissivities are considered to be most reliable. Areas where little or no aquifer-test data exist and the model is insensitive to the transmissivities are considered to be the least reliable. Unfortunately, nearly one-half of the area of the Floridan is in the "least reliable" category.

The transmissivity of the Upper Floridan is directly related to the thickness and lithology of its upper confining unit (principally comprised of the Miocene Hawthorn Formation). Removal of the Hawthorn during Pleistocene time is largely responsible for the distribution of current karst (Stringfield, 1966) and, thus, for the occurrence of high transmissivity in the Upper Floridan. Comparison of plate 2 with the map showing confined/unconfined conditions for the Upper Floridan (pl. 1) shows that the confined areas generally have lower transmissivity than the semiconfined or unconfined areas. The relationship among confiningunit thickness, development of solution cavities, and transmissivity in various geographic areas underlain by the Upper Floridan is summarized in table 3. High transmissivity is closely associated with thin confinement and solution-cavity development. Conversely, lower transmissivity is always associated with thick confinement and lack of solutioning. Thus a 500-ft section of thickly confined aquifer in western panhandle Florida may have a much smaller transmissivity than a 100-ft section of semiconfined aquifer in southwest Georgia.

Another factor that affects transmissivity is the occurrence of paleokarst at unconformities. For example, a very permeable zone is near the top of the Upper Floridan in the thickly confined area of coastal southeast Georgia. This zone occurs just below the unconformable contact between the Upper Eocene Ocala Limestone in the Floridan and the overlying clays of the Miocene Hawthorn Formation. Other factors affecting transmissivity include the original environment of deposition and diagenetic processes, especially dolomitization, as described in Professional Paper 1403-B (Miller, 1986).

The highest transmissivities (greater than 1,000,000 $\mathrm{ft}^{2} / \mathrm{d}$ occur in the karstic areas of central and northern Florida where the Floridan is generally unconfined or semiconfined. In these areas the upper part of the aquifer contains numerous caves, sinkholes, pipes, and other types of solution openings which account for the high transmissivity. Where the Floridan is confined, its transmissivity is generally less than $250,000 \mathrm{ft}^{2} / \mathrm{d}$, and transmissivity variations are due to variations in the lithology, aquifer thickness, and occurrence of paleokarst.

Transmissivities are lowest (less than $50,000 \mathrm{ft}^{2} / \mathrm{d}$ in the Florida panhandle, southernmost Florida, and the updip areas of Alabama, Georgia, and South Carolina. In the updip areas, the decreased transmissivity results simply from thinning of the aquifer. However, the development of karst in the outcrop area of southwest Georgia (Dougherty Plain) causes a sharp increase in transmissivity just downdip from the featheredge of the aquifer. A band of low transmissivity extends northeastward across south-central Georgia downdip of the outcrop area. This elongate strip of low transmissivity is associated with a series of small northeast-trending grabens (Miller, 1986, pl. 26). These grabens, taken together, are known as the Gulf Trough (Herrick and Vorhis, 1963). The lower transmissivity there is related to a reduction in the thickness of limestone by faulting (Gelbaum, 1978). This low transmissivity band has a marked control on the flow system, discussed in the section on predevelopment flow. The low transmissivity in the thick downdip sections of panhandle Florida and southernmost Florida results from a facies change in the carbonate rock. As discussed in Professional Paper 1403-B (Miller, 1986), the aquifer in this area contains large amounts of micritic limestone that has very low permeability.

The distribution of transmissivity in the Upper Floridan can be summarized as a continuum; from less than $1,000 \mathrm{ft}^{2} / \mathrm{d}$ in the confined micrite-rich limestones of the Fort Walton Beach area in western panhandle Florida to more than $1,000,000 \mathrm{ft}^{2} / \mathrm{d}$ in the unconfined karstic areas of central and northern Florida.

\section{LOWER FLORIDAN AQUIFER}

The lack of aquifer-test data precludes any areal definition of transmissivity in the Lower Floridan aquifer. In most areas, wells obtain sufficient supplies from the Upper Floridan, and little reason exists to drill into the Lower Floridan even where it contains potable water. 
TABLE 3.-Transmissivity and hydrogeologic conditions of the Upper Floridan aquifer and the upper confining unit in various localities

\begin{tabular}{|c|c|c|c|c|c|c|c|c|c|}
\hline \multirow{4}{*}{\multicolumn{2}{|c|}{ LOCALITY }} & \multirow{4}{*}{$\begin{array}{l}\text { TRANSMISSIVITY } \\
\text { (feet squared } \\
\text { per day) }\end{array}$} & \multicolumn{4}{|c|}{ UPPER FLORIDAN AQUIFER } & \multicolumn{3}{|c|}{ UPPER CONFINING UNIT } \\
\hline & & & \multirow{2}{*}{\multicolumn{2}{|c|}{\begin{tabular}{|c|} 
Thick \\
Solution cavities \\
\end{tabular}}} & \multirow{2}{*}{\multicolumn{2}{|c|}{\begin{tabular}{|c|}
$\begin{array}{c}\text { Thin (less than } \\
200 \text { feet) }\end{array}$ \\
Solution cavities \\
\end{tabular}}} & \multirow{3}{*}{$\begin{array}{l}\text { Thick } \\
\begin{array}{l}\text { Some } \\
\text { clayey } \\
\text { beds }\end{array}\end{array}$} & \multicolumn{2}{|c|}{$\begin{array}{l}\text { Thin (less than } \\
100 \text { feet) }\end{array}$} \\
\hline & & & & & & & & \multirow{2}{*}{ Clayey } & \multirow{2}{*}{$\begin{array}{l}\text { Sandy or } \\
\text { breached }\end{array}$} \\
\hline & & & Minor & Major & Minor & Major & & & \\
\hline \multicolumn{2}{|c|}{ Western Florida panhandle } & $1000-25,000$ & & & & & & & \\
\hline \multicolumn{2}{|c|}{ Southwest Georgia (Dougherty Plain) } & $10,000-200,000$ & & & & & & & \\
\hline \multicolumn{2}{|c|}{ Florida, south of Lake Okeechobee } & $10,000-60,000$ & & & & & & & \\
\hline \multicolumn{2}{|c|}{$\begin{array}{l}\text { Savannah, Georgia, to Jacksonville, } \\
\text { Florida, coastal area }\end{array}$} & $25,000-250,000$ & & & & & & & \\
\hline \multirow{2}{*}{$\begin{array}{l}\text { Central Florida, } \\
\text { northern Florida, } \\
\text { and adjacent } \\
\text { Georgia }\end{array}$} & $\begin{array}{l}\text { Major springs } \\
\text { area }\end{array}$ & $\begin{array}{l}\text { Greater than } \\
1,000,000\end{array}$ & & & & & & & \\
\hline & Elsewhere & $\begin{array}{l}\text { Mostly } 20,000-250,000 \\
\text { locaily } 250,000-1,000,000\end{array}$ & & & & & & & \\
\hline
\end{tabular}

${ }^{1}$ Aquifer test example described in text.

Aquifer-test data or well-performance information are thus very minimal. At Orlando and Jacksonville, watersupply wells tap the Lower Floridan, however. An aquifer test on an Orlando supply well provided a transmissivity value of more than $500,000 \mathrm{ft}^{2} / \mathrm{d}$ (Lichtler and others, 1968, p. 138), but this value is uncertain due to a very small response in a single observation well.

In the regional and subregional models, the Lower Floridan was simulated where it contains freshwater (less than $10,000 \mathrm{mg} / \mathrm{L}$ chloride). Model transmissivity values were assigned based partially on thickness of section and primarily on qualitative estimates of permeability inferred from geophysical log patterns and lithologic logs (J. A. Miller, U.S. Geological Survey, oral commun., 1980). Simulated Upper and Lower Floridan heads were insensitive to changes in Lower Floridan transmissivity values (Krause, 1982, p. 22; Tibbals, 1981, p. 21; Bush, 1982, figs. 11 and 12). Therefore, the flow models provided little basis for improving the initial areal distribution of Lower Floridan transmissivity.

The Lower Floridan aquifer in south Florida includes a highly permeable cavernous unit known as the "Boulder Zone" (see further discussions in Professional Papers 1403-B and 1403-G). This zone contains saline water and has been used for the underground disposal of treated sewage and industrial waste via deep injection wells. Because pressure buildup has been very small or insignificant in injection wells or nearby observation wells, analysis for aquifer properties has been difficult. However, an estimate of the transmissivity of the Boulder Zone was obtained by Meyer (1974) based on an analysis of natural water-level fluctuations (caused by earth tides and ocean tides) in a disposal well near Miami. This analysis provided an estimated transmissivity of $3,000,000 \mathrm{ft}^{2} / \mathrm{d}$. This value is for a $15-\mathrm{ft}$ thickness of aquifer and suggests that the Boulder Zone has an extremely high transmissivity. More recently, an aquifer test on a fully penetrating well in the Boulder Zone near Miami gave a transmissivity of $25,000,000$ $\mathrm{ft}^{2} / \mathrm{d}$ (Singh and others, 1983). The occurrence of such highly permeable solution-riddled zones in the Lower Floridan has been attributed to paleokarst development (Stringfield, 1966, p. 200-201).

\section{STORAGE COEFFICIENT}

Storage coefficient is generally reported along with transmissivity to describe hydrogeologic properties of aquifers. But the importance of storage coefficient in 
predicting the aquifer system's response to pumping is less straightforward than that of transmissivity. The importance of storage coefficient varies with the hydrogeologic characteristics of the area of interest and the assumed pumping conditions.

The storage coefficients calculated from aquifer-test data in table 2 range from a low of $1 \times 10^{-5}$ to a high of 0.02 with most values in the $0.001-1 \times 10^{-4}$ range. In theory, storage coefficient in confined aquifers is directly proportional to aquifer thickness. But in the Floridan aquifer system, reported storage coefficients bear no discernible relation to thickness of aquifer tested on a regional basis. The higher values, $0.01-0.001$, reflect the unconfined or semiconfined nature of parts of the system, particularly southwest Georgia, where the aquifer is very close to land surface.

An initial assumption was that an areal distribution of storage coefficient could be developed from a transient calibration of the digital flow model. But it became apparent that available data were insufficient to allow a transient calibration of storage coefficient. Figures 9 through 12 illustrate the relative importance of storage coefficient in different hydrogeologic areas. In each of the transient simulations that produced the data plotted in the four figures, the initial head condition from which pumping began was predevelopment-an average steady-state condition. The figures suggest that, depending on hydrogeolgic conditions and the value of storage coefficient, the time required from the start of a new pumping period for the system to reach a new steady-state condition can range from days to years. Unless pumping is constant for a period longer than the time it takes to reach equilibrium and natural stresses are minimal, the aquifer system is never at steady state. Without a known steady-state initial condition, any transient simulation of the aquifer system will produce heads different from measured heads until such time as the transient effects of the unknown stresses that caused the system to be in a nonequilibrium state die out. Therefore, unless the history of pumping (and other stresses due to climatic changes) with time is known for a period longer than that necessary for the effects of unknown initial stresses to cease, a digital model is little help in determining storage coefficient. This is because the modeling calibration process requires varying storage coefficient in a series of simulations until the simulated heads match the measured heads.

The data plots in the four figures also show that nearly continuous water level and accurate pumping data
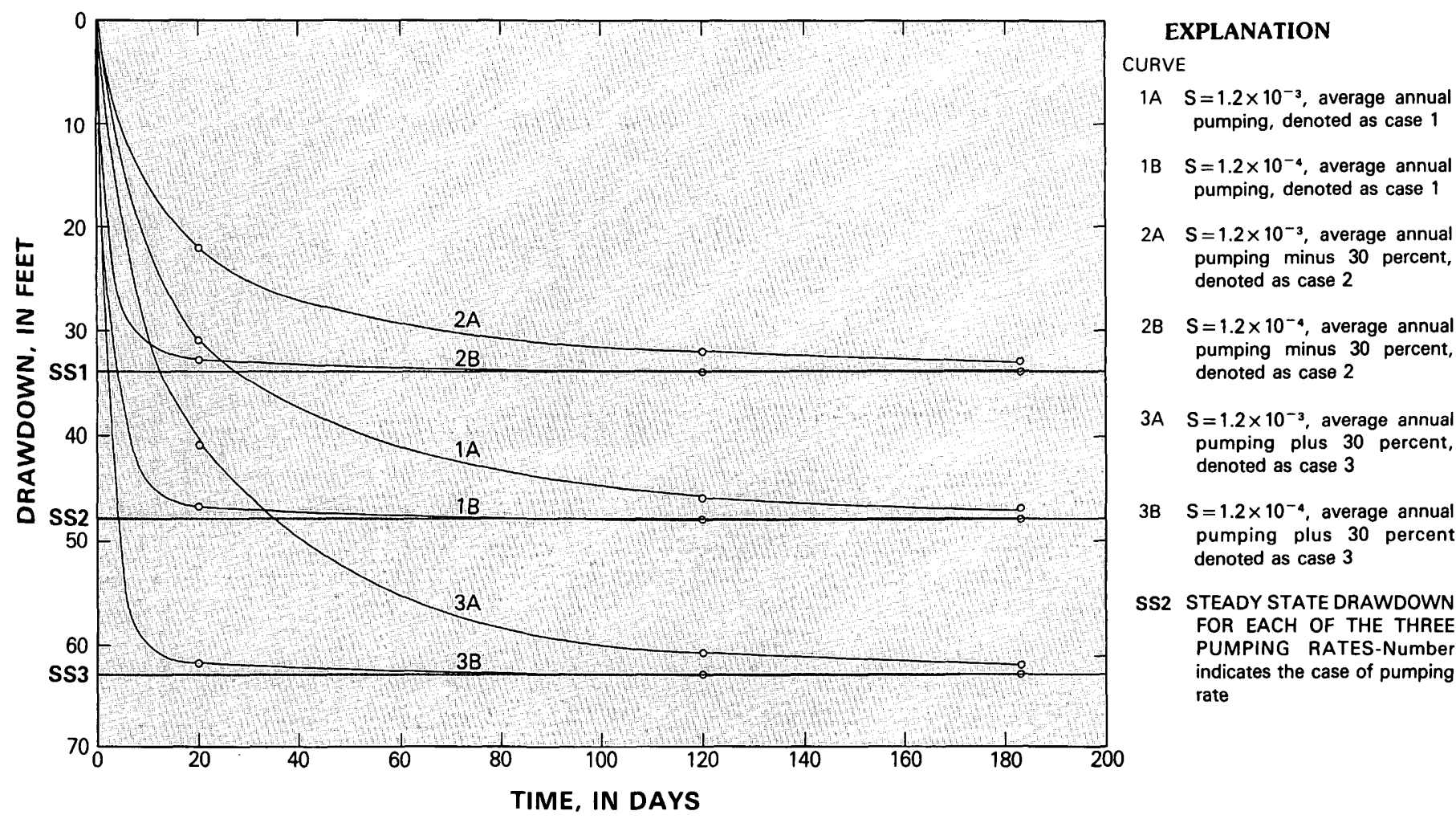

$3 \mathrm{~A} S=1.2 \times 10^{-3}$, average annual pumping plus 30 percent, denoted as case 3

$3 B \quad S=1.2 \times 10^{-4}$, average annua pumping plus 30 percent denoted as case 3

SS2 STEADY STATE DRAWDOWN FOR EACH OF THE THREE PUMPING RATES-Number indicates the case of pumping rate

FIGURE 9.-Simulated drawdown versus time for different storage coefficients and pumping rates, Polk County, Fla. 


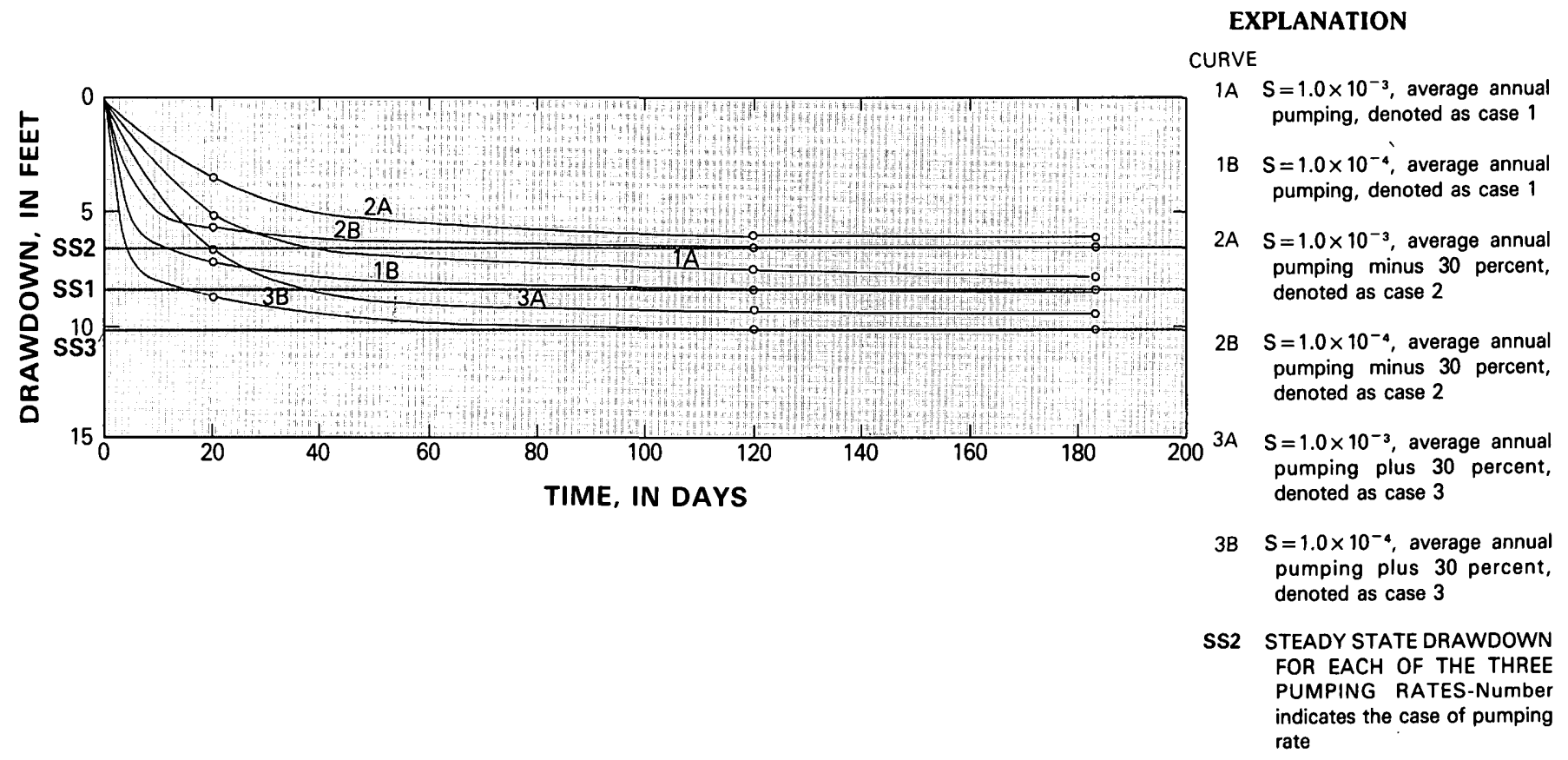

Figure 10.-Simulated drawdown versus time for different storage coefficients and pumping rates, Orange County, Fla.

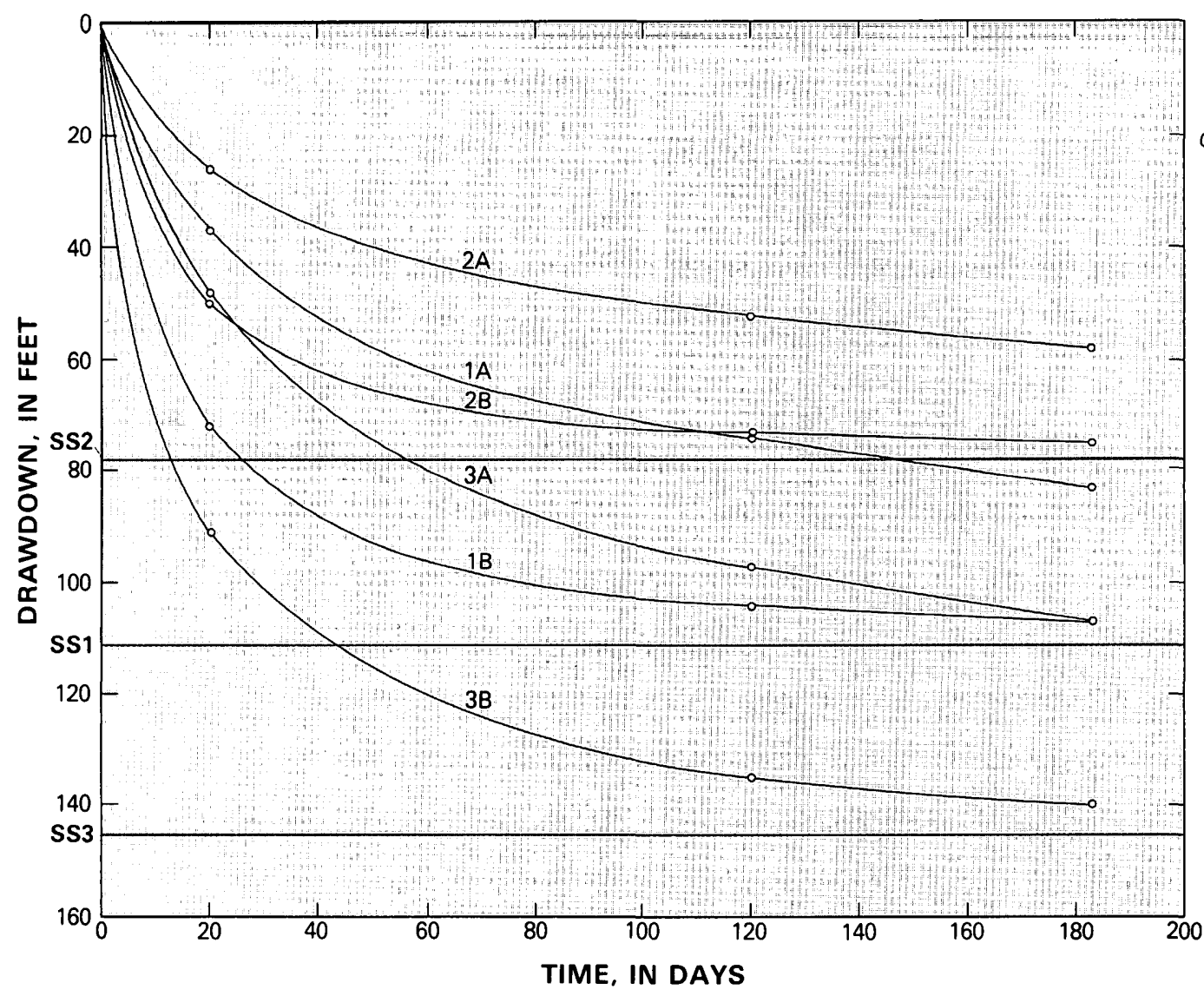

\section{EXPLANATION}

CURVE

1A $S=1.0 \times 10^{-3}$, average annual pumping, denoted as case 1

$1 B \quad S=1.0 \times 10^{-4}$, average annual pumping, denoted as case 1

$2 \mathrm{~A} S=1.0 \times 10^{-3}$, average annual pumping minus 30 percent, denoted as case 2

$28 \mathrm{~S}=1.0 \times 10^{-4}$, average annual pumping minus 30 percent, denoted as case 2

$3 A \quad S=1.0 \times 10^{-3}$ average annual pumping plus 30 percent, denoted as case 3

3B $S=1.0 \times 10^{-4}$, average annual pumping plus 30 percent, denoted as case 3

SS2 STEADY STATE DRAWDOWN FOR EACH OF THE THREE PUMPING RATES-Number indicates the case of pumping rate

FIGURE 11.-Simulated drawdown versus time for different storage coefficients and pumping rates, Savannah, Ga. 


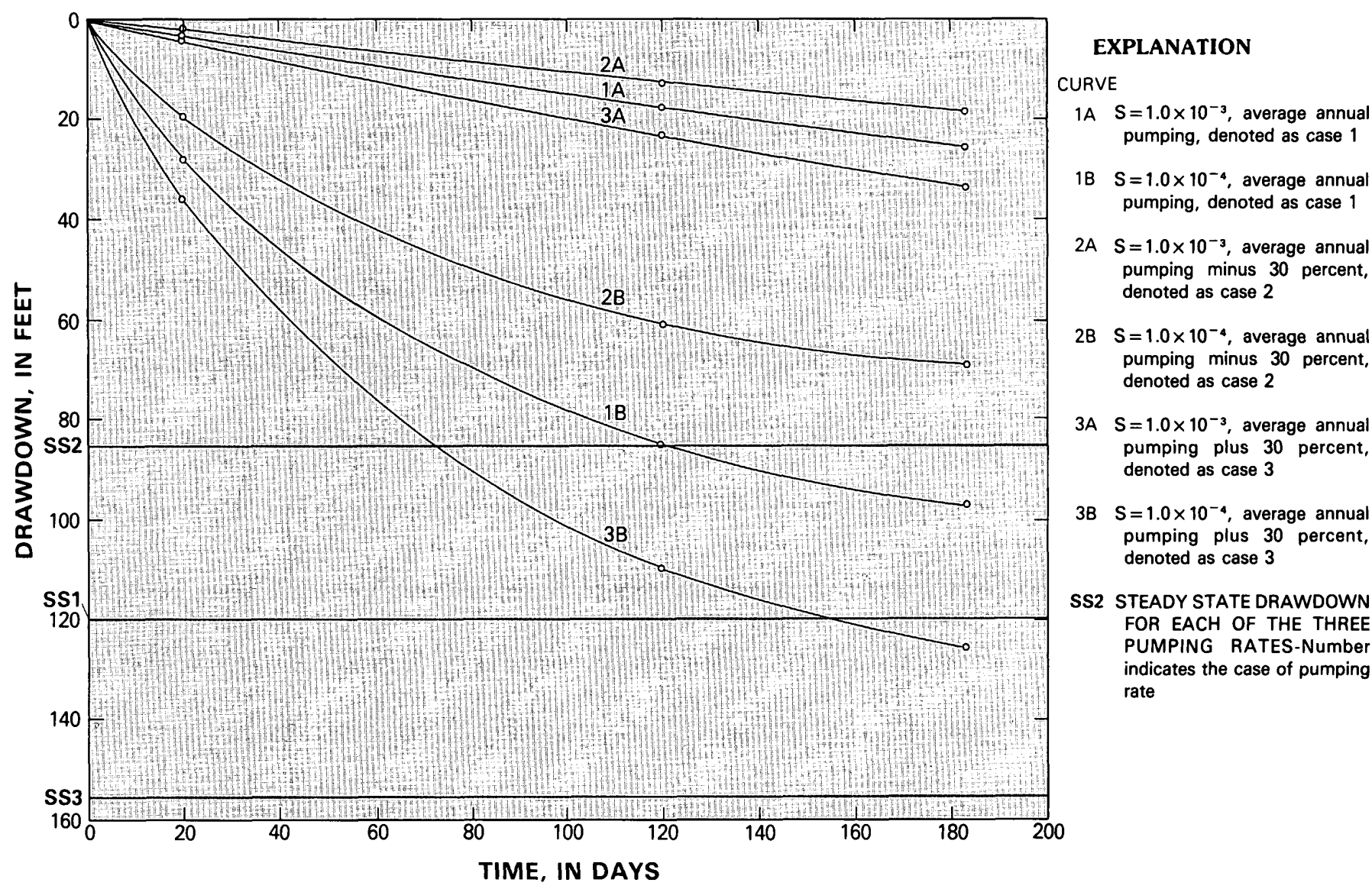

Figure 12.-Simulated drawdown versus time for different storage coefficients and pumping rates, Fort Walton Beach, Fla.

during a pumping period, particularly the early part, are necessary for comparison with simulated timedrawdown plots to estimate storage coefficient with confidence. Such data for major pumping centers almost never exist. A realistic example of the dilemma occurs in Polk County, Fla. (fig. 9), a heavily stressed area where agricultural pumping is appreciable. Primarily because of the uncertainty in estimating agricultural pumpage, confidence in the estimate of total pumpage is only about plus or minus 30 percent. Storage coefficients are known from aquifer tests to fall into the 0.001-1 $\times 10^{-4}$ range. The time-drawdown plots for transient simulations using combinations of the estimated limits of pumping and storage coefficient show that during the first 30 days or so, many combinations of realistic storage coefficient and pumping rate would produce drawdown values in the $30-50-\mathrm{ft}$ range. Thus, to use a model to estimate storage coefficient accurately, nearly continuous time-drawdown data and more precise estimates of pumpage would be needed before a match of measured and simulated timedrawdown plots could be made.

Thus, because of the lack of steady-state initial conditions and historical pumping and associated water-level data, an areal distribution of storage coefficient was not derived by digital modeling.

However, digital modeling has provided useful insight about storage and storage coefficient in the aquifer system. The time-drawdown data in the four figures imply, considering the hydrogeologic characteristics of the four areas represented, that the time needed from the start of a new pumping period for the system to reach steady state in confined areas depends on the fraction of water pumped that must come from storage. If the water necessary to sustain a given pumping rate is readily available from vertical leakage (induced recharge) or adjacent areas within the aquifer (diversion of natural discharge), then only a small part of the water pumped will come from storage and a steady-state condition will be achieved relatively quickly. With each of the two storage-coefficient values tested, the aquifer system will come to steady state in less time in the two central Florida locations than in the Savannah, Ga., area; and the system in Savannah will achieve a steady. state condition more quickly than the system in the Fort Walton Beach, Fla., area.

The Polk County, Fla., location has an estimated transmissivity of $130,000 \mathrm{ft}^{2} / \mathrm{d}$ and an estimated 
leakage coefficient of $2.8 \times 10^{-5}$ per day. Estimated transmissivity and leakage coefficient at the Orange County, Fla., location are $200,000 \mathrm{ft}^{2} / \mathrm{d}$ and $1.3 \times 10^{-5}$ per day. Near Savannah, Ga., estimated transmissivity and leakage coefficient are $40,000 \mathrm{ft}^{2} / \mathrm{d}$ and $5.4 \times 10^{-7}$ per day. Near Fort Walton Beach, Fla., estimated transmissivity and leakage coefficient are $2,000 \mathrm{ft}^{2} / \mathrm{d}$ and $2.4 \times 10^{-7}$ per day.

Figures 9 and 10 imply a roughly comparable and relatively low dependence on water from storage in Polk and Orange Counties during transient pumping. At Savannah (fig. 11), where water available from leakage and from adjacent parts of the aquifer is considerably less, proportionately more water must come from storage, thus increasing the time required to reach equilibrium. At Fort Walton Beach (fig. 12), the most tightly confined, least transmissive of the four areas proportionately even more water must come from storage, thus further increasing the time to reach the steady-state condition.

The figures also show, not surprisingly, that, as dependence on water from storage increases, the system's sensitivity to the value of storage coefficient also increases. After 120 days of simulated pumping at the same average annual rate at each of the two central Florida locations, both storage-coefficient values result in heads less than $2 \mathrm{ft}$ apart. At Savannah the difference in computed heads after 120 days pumping at the average annual rate using storage coefficients of 0.001 and $1 \times 10^{-4}$, respectively, is about $30 \mathrm{ft}$. And at Fort Walton Beach, the simulated head after 120 days pumping at the average annual rate using a storage coefficient of 0.001 is almost $70 \mathrm{ft}$ higher than the head computed using $1 \times 10^{-4}$.

Storage coefficient is of interest in situations where the transient response to pumping is desired; that is, in predicting how heads will change during pumping before steady state is achieved. Because tightly confined, low-transmissivity areas are relatively slow to reach equilibrium, prediction of water-level response to pumping in these areas is more dependent on accurate storage-coefficient estimates than in other areas. For example, assume storage coefficient in both panhandle Florida and west-central Florida is estimated to be 0.001 when the true value is $1 \times 10^{-4}$. If four 120 -day pumping periods are simulated with digital models of panhandle Florida and west-central Florida, clearly the cumulative head error at the end of the simulations would be considerably greater at Fort Walton Beach than at Polk County.

An areal distribution of storage coefficient is difficult if not impossible to obtain in practice. If evaluation of transient pumping response in the Floridan aquifer system is needed, the relative importance of, or the need to know storage coefficient, depends primarily on the hydrogeologic characteristics of the area of interest.

\section{LEAKAGE COEFFICIENT}

\section{UPPER CONFINING UNIT}

The term "leakage coefficient" when associated with the upper confining unit of the Floridan aquifer system refers to the quantity of water that flows to (or from) the upper Floridan aquifer from (or to) the surficial aquifer, per unit surface area, per foot of head difference.

Leakage coefficient of the upper confining unit determined from aquifer-test data is reported for 15 of the 114 tests documented in table 2. These data were selected from among a larger group of leaky aquifer tests to represent the best available field-determined values of leakage coefficient. The values range from 88 (in./yr)/ft (0.02 per day) to 0.44 (in./yr)/ft $\left(1 \times 10^{-4}\right.$ per day).

In most areas the rocks that compose the upper confining unit vary greatly in lithology and are complexly interbedded; thus, little is known about their hydraulic characteristics. For this reason simulated values of leakage coefficient for the upper confining unit in most areas were obtained by dividing estimates of predevelopment recharge and discharge rate (developed from regional model calibration) by estimates of predevelopment head difference between the surficial aquifer and the Upper Floridan aquifer (Bush, 1982, p. 23). Simulated leakage coefficients in most areas are thus the result of adjusting recharge and discharge rates during calibration, rather than adjusting estimates of vertical hydraulic conductivity and (or) thickness of the upper confining unit.

Plate 3 shows the values of leakage coefficient for the upper confining unit required to deliver simulated rates of vertical flow between the surficial aquifer and the Upper Floridan aquifer. The ranges of values shown vary from greater than 1.00 (in./yr)/ft $\left(2.28 \times 10^{-4}\right.$ per day) in semiconfined areas to less than 0.01 (in./yr)/ft $\left(2.28 \times 10^{-6}\right.$ per day) in tightly confined areas.

The field-determined values of leakage coefficient are also plotted on plate 3. Comparison of field-determined values with simulated values in the same locations generally shows a marked discrepancy between the two. The leakage coefficients calculated from aquifer-test data are in general very much larger than those obtained from the simulation. At most test sites, leakage coefficients from aquifer-test data are too large to realistically represent the exchange of water between the surficial aquifer and the Upper Floridan. For example, in the vicinity of the Green Swamp aquifer test (site 85 on pl. 3), simulation of current average aquifer 
conditions results in a leakage rate of about $6 \mathrm{in} . / \mathrm{yr}$ in the vicinity of the test site. Average head difference between the surficial aquifer and the Upper Floridan at the test site is probably less than $1 \mathrm{ft}$. The fielddetermined leakage coefficient of 88 (in./yr)/ft ( 0.02 per day) is clearly too large to produce leakage in a range close to 6 in./yr.

Workers reporting leakage coefficients obtained from aquifer-test data (Tibbals and Grubb, 1982, p. 14; Miller and others, 1978, p. 96; Bentley, 1977, p. 43) have observed that values can reflect not only downward leakage from the surficial aquifer, but upward leakage from permeable rocks beneath the pumped interval, and leakage from beds of relatively low permeability that might exist within the pumped interval. Wells in the Floridan aquifer system are usually partially penetrating and often intersect local low-permeability units. Thus, in most leaky Floridan test situations, the leakage coefficients of the upper confining unit from test data probably characterize leakage from all sources, not just downward leakage from the upper confining unit or the surficial aquifer.

Throughout northwest-central Florida (the area designated as unconfined on pl. 3), confined, semiconfined, or unconfined conditions may occur locally. A thin layer of surficial sand usually overlies the Upper Floridan aquifer; however, this sand section can be thick or clayey locally. At the site of the Dunnellon, Fla., aquifer test within this area (number 82 on pls. 2 and 3 ), the aquifer is overlain by a layer of sand about $200 \mathrm{ft}$ thick that becomes clayey in the lowermost $80 \mathrm{ft}$ or so. When pumped, the aquifer at the site definitely exhibits leaky confined behavior, and a leakage coefficient was determined.

A largely unanswered question (because of a lack of shallow-well water-level data) about the area designated as unconfined is whether or not a regional water table exists at an altitude appreciably different from the potentiometric surface of the Upper Floridan. A distinct and separate water table would imply at least some degree of confinement in the area. Relatively high rates of recharge in northwest-central Florida determined from simulation suggest that, on the average areally, confinement is minimal to nonexistent.

The Dougherty Plain in southwest Georgia and adjacent Jackson and Washington Counties, Fla., is another area where the Floridan locally is confined, semiconfined, or unconfined; however, semiconfined conditions probably predominate. The aquifer is overlain by a thin (30-60-ft thick) layer of clayey residuum that generally provides effective confinement where it is continuous; but locally the residuum can be mostly sand or breached by sinkholes, characteristics that tend to make the aquifer behave as unconfined. Much of the area in southwest Georgia and Jackson and Washing. ton Counties, Fla., is labeled "unconfined or semiconfined" on plate 1 .

Plate 1 primarily reflects a geologic interpretation of aquifer conditions based on geologic maps of Georgia (Georgia Geological Survey, 1976) and Florida (Puri and Vernon, 1964, pl. 2). For purposes of simulating the flow system, the area was considered semiconfined with a water table distinct from the potentiometric surface of the Upper Floridan aquifer. Therefore, the areal distribution of simulated leakage coefficient values for the upper confining unit extends throughout this area. Not unexpectedly, the largest concentration of high leakage-coefficient values for the upper confining unit occurs in the southwest Georgia-northwest Florida area.

The small inset map on plate 3 shows the sensitivity of the simulated predevelopment head in the Upper Floridan to changes in simulated leakage coefficient for the upper confining unit. This map provides at least an indirect way to evaluate the range of leakage-coefficient values shown on the large map. Where heads are extremely sensitive to changes in the leakage coefficient, the presumption is that only a narrow range of leakage coefficient values will allow correct simulation of heads. Thus, the values shown on the large map in the area that is coincident with the "extremely sensitive" area of the inset map are considered most likely to approximately represent true values of the leakage coefficient for the upper confining unit. Where heads are insensitive to changes in leakage coefficient, a wide range of leakage-coefficient values permits accurate simulation of heads. Therefore, accurate head simulation provides much less of a basis for judging whether or not leakagecoefficient values are correct in areas of the aquifer labeled "insensitive." This judgment must be made using factors other than simulated heads; for example, the distribution of recharge and discharge.

\section{MIDDLE CONFINING UNIT}

The leakage coefficient of the middle confining unit is the quantity of water that flows from (or to) the Upper Floridan aquifer to (or from) the Lower Floridan, per unit surface area, per foot of head difference.

No quantitative field data on the water-transmitting characteristics of this unit exist. Miller, in his hydrogeologic discussion of the unit in Professional Paper 1403-B, uses lithology and thickness to qualitatively assess the degree of confinement offered by each of seven low-permeability units of subregional extent that together compose the middle confining unit. Parts of three of these seven subunits separate aquifers containing freshwater and were simulated by the regional flow model. Leakage-coefficient values for simulation were 
arbitrarily assigned based on Miller's geological assessment of the degree of confinement. Subregional and regional simulation showed that predevelopment heads in the Upper and Lower Floridan were very insensitive to changes in values of middle-confining-unit leakage coefficient (Krause, 1982, p. 22; Tibbals, 1981, p. 21; Bush, 1982, figs. 11 and 12). Thus, as was the case with Lower Floridan transmissivity, the flow models could not be used to refine the initial areal distribution of the leakage coefficient values for the middle confining unit. For this reason and because of the lack of quantitative field data, no regional map showing an areal distribution of middle-confining-unit leakage coefficient is presented in this report.

\section{THE REGIONAL FLOW SYSTEM}

\section{REGIONAL FLOW MODEL}

The principal tool used to study the regional flow system was a three-dimensional finite-difference model (Trescott, 1975; Trescott and Larson, 1976). The model simulates head and flow response of a multilayered aquifer system to natural and manmade stresses. Simulation is achieved by solving finite-difference approximations of the three-dimensional ground-water flow equation (Trescott, 1975, equation 4, p. 4) using the strongly implicit method. This iterative-solution algorithm is discussed in detail in Remson and others (1971), and Trescott and others (1976).

In a true three-dimensional multilayered simulation, aquifers and confining units are treated as individual layers. Head distribution and flow in each layer and vertical exchange of water between adjacent layers are computed simultaneously. This type of simulation requires a large amount of computer storage and time, as well as field data on all layers. Because field data are commonly lacking and true three-dimensional simulation is not practical, Trescott (1975) made a quasi-threedimensional variation of his model. This model assumes that horizontal flow in confining units is negligible and only vertical flow occurs between adjacent aquifers through confining units. This assumption is generally valid since the contrast in permeability between the aquifer and confining layers is usually large (Hantush, 1960, in Bredehoeft and Pinder, 1970). Storage within the confining layers is neglected and a Darcy-type expression for steady vertical leakage is incorporated into the finite-difference equations as a source term. This term provides for the exchange of water between aquifers and at the same time simulates a confining layer's resistance to vertical flow because a leakage coefficient is incorporated in the term. In some aquifer systems the contribution of water from confining-layer storage is significant. Several investigators (Posson and others, 1980; Leahy, 1982; Torak and Whiteman, 1982) have modified the Trescott quasi-three-dimensional model to simulate the effects of transient leakage from confining-layer storage. However, during this investigation, the storage in the confining units is neglected.

The model of the regional flow system is a quasi-threedimensional four-layer model structured within a 65-row by 80 -column finite-difference grid. The model design, assumptions, and application to simulating the regionalpredevelopment-flow system has been described by Bush (1982). Each node, or grid block, is $8 \mathrm{mi}$ on a side and thus represents a $64-\mathrm{mi}^{2}$ area. For simulation, the properties of an aquifer layer are averaged and assumed to be constant within each grid block. The value of a particular aquifer property in a grid block is an average over the grid-block area.

A major assumption in applying the model on a regional scale is that flow in the Floridan behaves as flow in a porous medium. In the hydraulics section, the authors indicate that this assumption is probably valid on a scale of several hundred feet (the scale of a typical Upper Floridan aquifer test) except in the karstic areas. In the karstic areas of central and northwest Florida, especially near major springs, conduit flow occurs on a local scale (hundreds to thousands of feet). At the scale of the regional model (with 8-mi grid-block spacing), flow in the karstic spring areas can also be treated as porousmedia flow.

Figure 13 is a plan view of the simulated area showing the grid and layer boundaries, and figure 14 is a cross section showing the model's vertical structure. The surficial aquifer, where present, is simulated as a constant-head layer. As such, it provides a source or sink for water flowing vertically into or out of the Upper Floridan aquifer. A disadvantage of designating the surficial aquifer as a constant-head layer is that the heads in the surficial aquifer are assumed to be unaffected by pumping from the Upper Floridan, which may not be the case. But the slight gain in accuracy that might be attained by actually simulating the surficial aquifer was judged to be offset by the added complexity and potential problems (lack of knowledge of surficial-aquifer properties; difficulty in realistically simulating the unknown evapotranspiration and runoff) associated with that alternative.

The Upper Floridan aquifer in most of northwestcentral Florida is considered unconfined and the surficial aquifer is not part of the model there (figs. 13 and 14). The Upper Floridan receives direct recharge and directly discharges water in this area. The recharge rate varies areally but remains constant with time. Considering the prevailing hydrologic conditions in northwest-central 


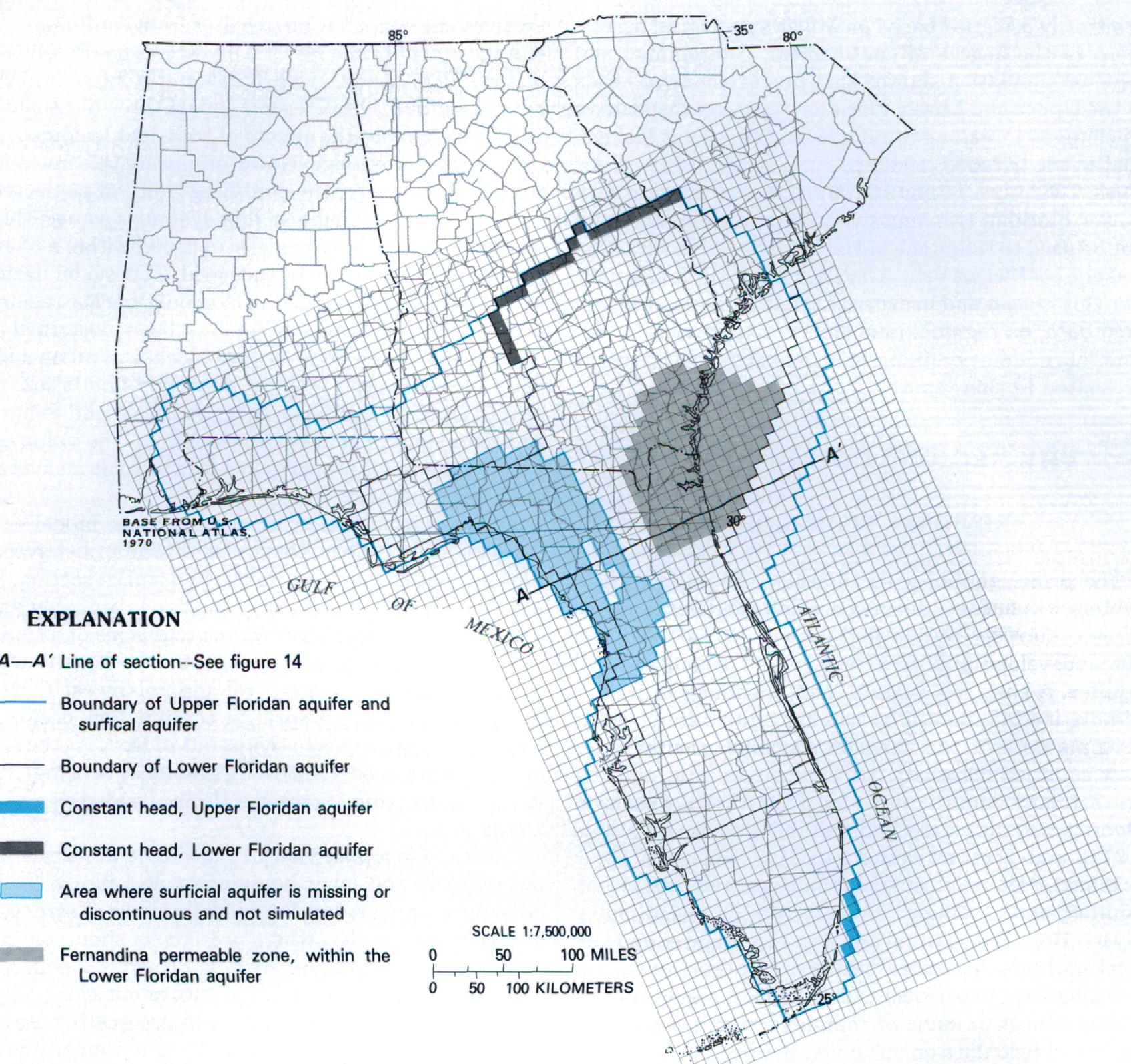

FiguRE 13.-Regional model grid and layer boundaries.

Florida, this approach was judged reasonable. Throughout most of the area, water recharges the Upper Floridan at or near the maximum rate available (see end of the following section on components of the hydrologic budget); transmissivity is high; ground-water discharge through springs is high; and surface runoff is nonexistent. No appreciable pumping presently occurs in the area, but, if heavy pumping were to occur, little additional recharge would be induced under the existing hydrologic conditions.

The Upper Floridan and the Lower Floridan are simulated as active layers; that is, heads are computed for each model grid block. Faults, joints, fractures, and other solution-related features in the carbonate system cause heterogeneity and anisotropy. No regional principal directions of anisotropy have been identified. Only lateral flow can be simulated in the aquifers. The model simulates anisotropy and heterogeneity indirectly through areal variation of transmissivity. (Because each model grid block has only one transmissivity value associated with it, the model has no intra-block anisotropy and heterogeneity.) 


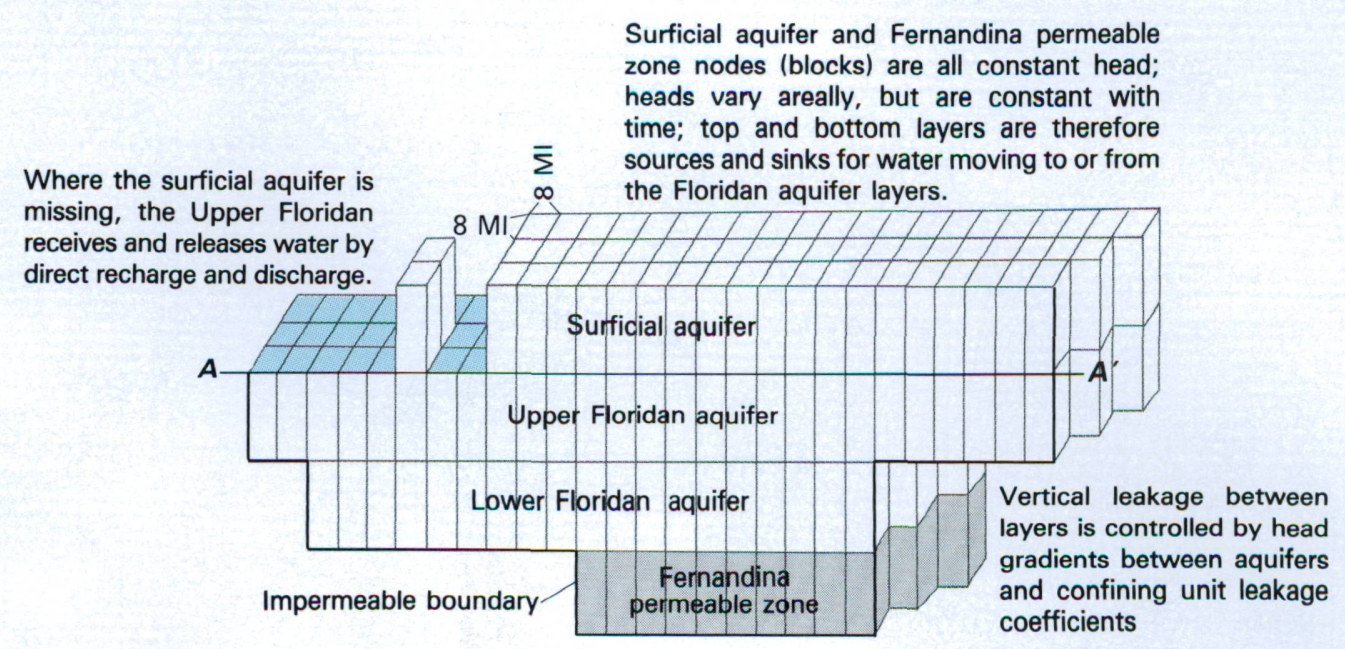

FIGURE 14.-Vertical structure of the regional flow model.

Unless otherwise indicated, the boundaries shown for each layer in figure 13 are no-flow boundaries. In coastal areas, the boundaries on the Upper and Lower Floridan aquifers correspond to the estimated lateral extent of the predevelopment freshwater flow system in the two aquifers. A basic assumption about the Floridan aquifer system in and near coastal areas is that a stable freshwater-saltwater interface exists at depth, rises seaward, and ultimately intersects the top of the aquifer. Beneath the interface, static saltwater exists; flowing freshwater occurs above the interface. Thus, a no-flow boundary condition was used to simulate the interface.

The term "interface" is used loosely; generally it refers to a transition zone of usually undetermined thickness. Therefore, the boundary of the freshwater flow system is placed at the estimated midpoint of the transition zone between freshwater and seawater, which would correspond to a chloride concentration of about $10,000 \mathrm{mg} / \mathrm{L}$. Thus, all water of less than $10,000 \mathrm{mg} / \mathrm{L}$ chloride is considered part of the freshwater flow system, even though for water-supply purposes freshwater is generally defined as water containing less than $250 \mathrm{mg} / \mathrm{L}$ chloride. The seaward extent of freshwater flow in the Upper and Lower Floridan aquifers is based on the estimated altitude of the predevelopment freshwater head on the interface and available chlorideconcentration data in unstressed areas. The method used to locate the coastal boundaries has been explained by Bush (1982, p. 24-25).

The boundary of the Upper Floridan aquifer along the southeast Florida coast is simulated with constant-head nodes to allow for submarine discharge of ground water offshore from Miami. Interpretations of recent offshore seismic data indicate outcropping limestone along submerged terraces as described in Professional Paper 1403-G (Meyer, in press). Constant-head values were obtained by computing the freshwater head equivalent to the saltwater head at the submerged outcrop area.

The northern no-flow boundary of the Upper Floridan aquifer shown in figure 13 coincides with the approximate updip limit of the Floridan aquifer system. Further discussion of this boundary, the east (South Carolina) and west boundaries (Alabama), and the rationale for simulating them as no-flow is in Bush (1982, p. $3,5,23-24)$.

The flow system was simulated in four subregional flow models with finer mesh grids than that of the regional model. Each subregional-model grid block is $4 \mathrm{mi}$ on a side. Each subregional model grid is aligned the same as the regional-model grid (fig. 15). Thus, each regional grid block exactly overlies four subregional grid blocks where the regional and subregional models are coincident. In addition, two finer mesh models (1-mi by 1-mi grid blocks) were used for simulating flow in two heavily developed areas: the Fort Walton Beach area of Florida and the Dougherty Plain area of southwest Georgia.

The four subregional models were intended to provide more detailed simulations in areas where appreciable ground-water development has occurred. To the extent feasible, subregional-model boundaries were aligned with predevelopment ground-water basin boundaries so that mostly no-flow boundary conditions could be applied during subregional-model calibration.

In the northern part of its occurrence, the Lower Floridan aquifer grades into clastic rocks that are generally less permeable than the carbonate rocks. These clastic rocks are considered part of the lower confining unit in the regional-hydrogeologic framework of the 


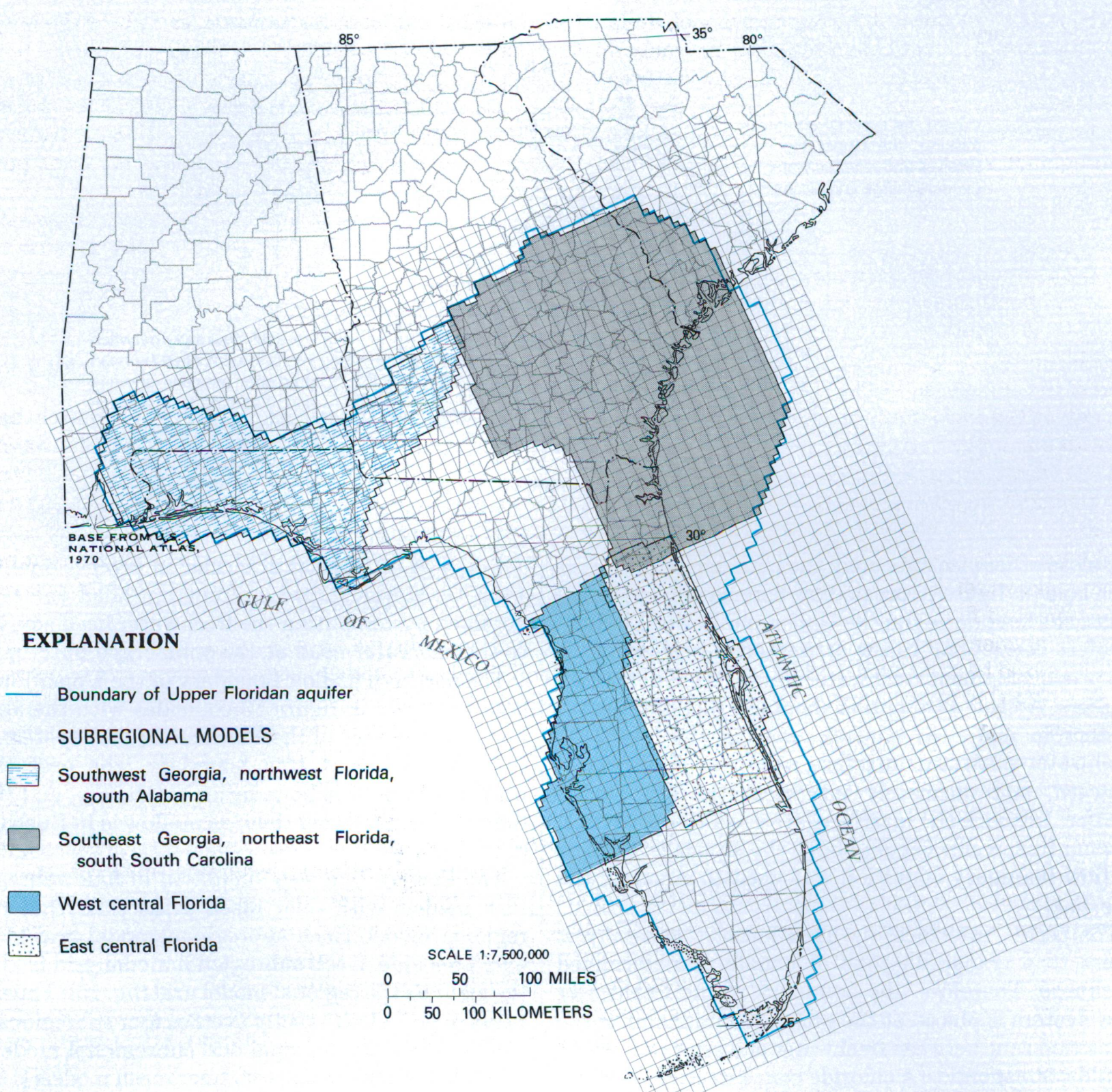

FIGURE 15.-Relation among subregional and regional flow-model grids.

Floridan as defined by Miller (1986). However, these clastic rocks contain permeable sands that are hydraulically connected to the Lower Floridan. Thus, an analysis of the flow system must consider the Lower Floridan and its updip sandy equivalents as one continuous "aquifer." Therefore, the regional model as well as the Georgia subregional model (Krause and Randolph, in press) simulate a Lower Floridan aquifer all the way to the updip limit of the carbonate system in the area coincident with the southeast Georgia subregional model. And, as in the subregional model, part of the regional model's northern Lower Floridan boundary is simulated as constant head (fig. 13) to allow for lateral inflow from hydraulically connected Lower Tertiary sand aquifers.

Although the Lower Floridan exists in parts of panhandle Florida and south Alabama (see Miller, 1986, pl. 32), it is thin (generally less than $200 \mathrm{ft}$ thick) and occurs only in a small area. Ground-water flow in the Upper Floridan overlying it is minimal. Thus, the Lower Floridan was excluded from the regional flow model in that area. 
The lowermost layer of the regional model, designated the Fernandina permeable zone, occurs only in the Jacksonville-Fernandina Beach-Brunswick area. The need to include this locally permeable zone near the base of the Lower Floridan aquifer became apparent during subregional simulation of heavy pumping from the Floridan in this area. Simulated heads under pumping conditions in the Upper and Lower Floridan aquifers were below observed heads because vertical leakage from above the pumped intervals was insufficient. The Fernandina permeable zone was considered to be the most logical source of the additional required leakage and is simulated as a constant-head layer. The lateral extent of the zone, as well as the simulated leakage coefficient of the local confining unit between the Lower Floridan and the Fernandina permeable zone, is based on interpretation of a limited amount of lithologic and geophysical log data (see Krause and Randolph, in press).

Spring discharge and direct Upper Floridan discharge to surface-water bodies together compose the major component of flow out of the Floridan aquifer system. This component is simulated in the regional model by a generalized head-dependent source-sink function (J. V. Tracy, U.S. Geological Survey, written commun., 1979) that can be used to simulate any process where discharge is a linear function of head gradient. (Basically the same modification to the finite-difference model was later documented in a report by L. J. Torak, 1982.) This application in the regional flow model is discussed in detail by Bush (1982, p. 31).

The approach in applying the model to the regional flow system was basically a two-phase process. The first phase was calibration, in which areal distributions of transmissivity, recharge, discharge, and leakage coefficient were estimated initially, then adjusted so that simulated heads and aquifer discharges closely matched the estimated steady-state predevelopment potentiometric surface of the Upper Floridan aquifer (pl. 4) and the observed or estimated aquifer discharge to springs and surface-water bodies. Calibration of the steadystate predevelopment flow model has been documented by Bush (1982). The second phase simulates the 1980 flow conditions in the aquifer system. As in the predevelopment calibration phase, the simulation of 1980 conditions was a steady-state simulation. For the reasons discussed in the storage-coefficient section, a transient calibration was not feasible.

The intent of the second modeling phase was to superimpose average 1980 pumping on the calibrated predevelopment model to see how closely the observed May 1980 potentiometric surface of the Upper Floridan aquifer could be simulated. If the match between simulated and observed potentiometric surfaces in the areas of pumping stress (the areas where the May 1980 potentiometric surface was different from the predevelopment potentiometric surface) was acceptable without adjusting initially calibrated transmissivity and leakage coefficient, then the areal distributions of transmissivity and leakage coefficient in the areas of pumping stress could also be considered acceptable. If the match could be improved upon and a hydrologic basis existed for changing the hydraulic properties to cause the improvement, then changes were made. In areas outside the influence of pumping, where 1980 aquifer conditions are essentially the same as predevelopment, transmissivity and leakage could not be tested by simulating the 1980 conditions.

What constitutes an "acceptable" match between simulated and observed 1980 heads is not always clear. Unlike regional error statistics (mean and standard deviation of head residuals) computed for predevelopment (calibration) conditions, regional error statistics computed for 1980 conditions are misleading because there is little or no pumping in much of the regional area, and the 1980 simulation is the same as the predevelopment simulation. The errors associated with the predevelopment simulation are small (Bush, 1982, p. 33). Thus, the errors for the 1980 simulation will also be small because more than one-half of the area has experienced no appreciable head decline. Calibration has therefore emphasized matching observed head declines and simulated head declines. Observed head declines are based on the difference between the estimated predevelopment potentiometric-surface map of the Upper Floridan aquifer (pl. 4) and the observed 1980 potentiometric-surface map (pl. 5). The difference is portrayed on plate 6 as the long-term regional water-level decline in the aquifer.

Figure 16 shows net head decline between simulated predevelopment and simulated 1980 heads. Comparison of figure 16 with plate 6 indicates that, except for the band of unrealistic decline across south Florida, the match between simulated net decline and observed net decline is acceptable.

Where the regional model is coincident with one of the subregional models, the grid-block values of the hydrologic parameters in the regional model are fourblock arithmetic averages of subregional-model gridblock values. In each of the three areas of regional water-level decline due to pumping, the respective subregional model more closely simulates 1980 conditions than the regional model. Resolution of the simulated flow system is lost when grid-block area is quadrupled.

The west-central Florida subregional model (Ryder, 1985) actively simulates an intermediate (Hawthorn) aquifer between the surficial aquifer and the Upper 


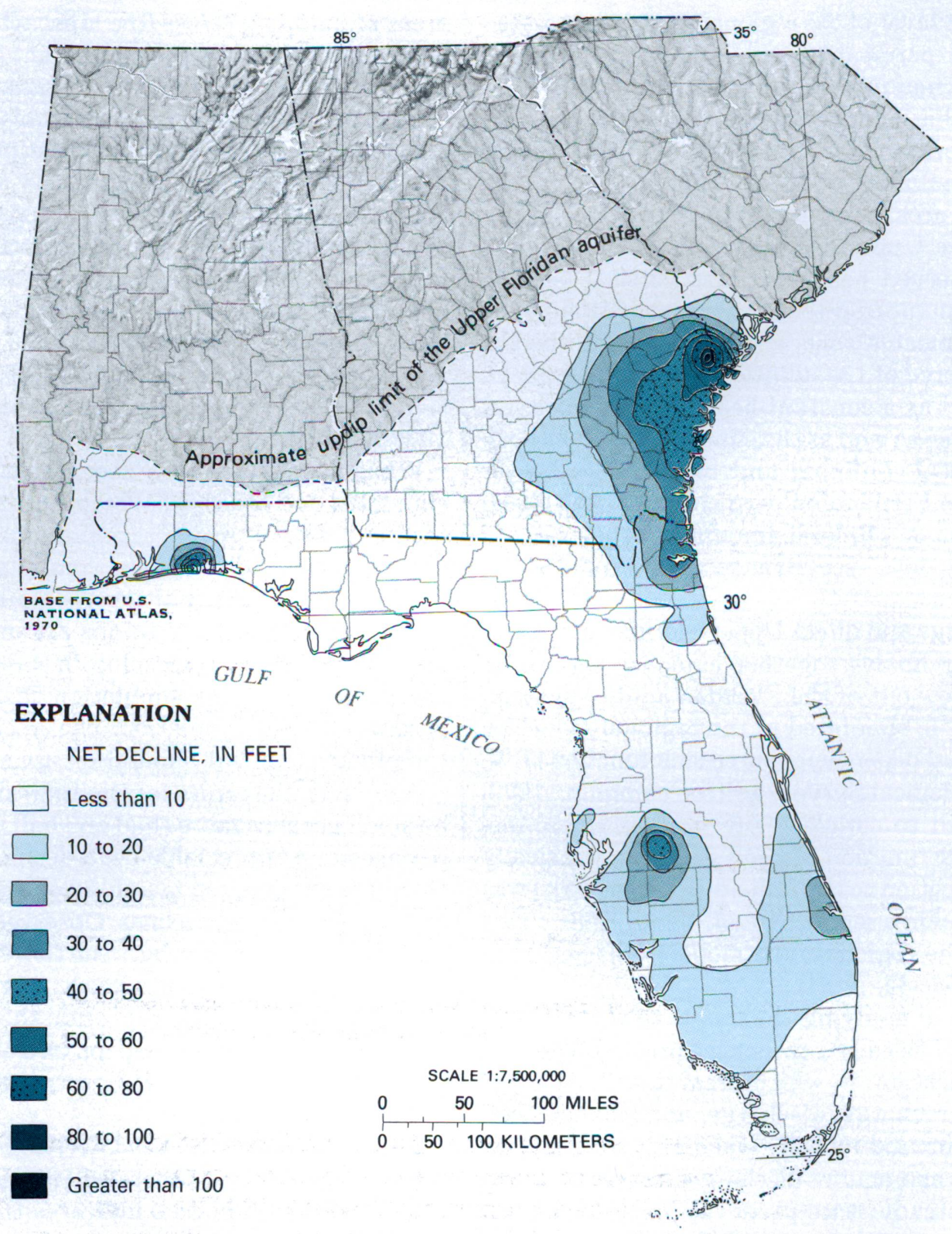

FIGURE 16.-Net decline between simulated predevelopment potentiometric surface and simulated May 1980 potentiometric surface of the Upper Floridan aquifer.

Floridan in the area of water-level decline (see pl. 3 for Hawthorn location). The regional model does not actively simulate the Hawthorn but includes it as part of the regional upper confining unit. This compromise contributes to some of the inaccuracy in regional simulation of 1980 conditions in west-central Florida.

Inherent inaccuracies and (or) inconsistencies exist in the two observed potentiometric-surface maps used as the basis for comparison with the simulated potentiometric surfaces. The predevelopment map is a composite of many maps; as such, it represents the best estimate of the "average" potentiometric surface as it existed prior to development. In contrast, the May 1980 map is a potentiometric surface at a single time. May is the seasonal low water-level period in peninsular Florida; however, May is nearer the average water-level period in the northern part of the regional area. Thus, the May 1980 potentiometric surface does not represent "average" heads regionwide in 1980.

Simulated "current" pumpage $\left(2,700 \mathrm{ft}^{3} / \mathrm{s}\right)$ is a 
composite of average annual pumpage estimates for different parts of the regional area for years ranging from 1976 to 1981. A composite of estimates from several recent years, rather than a single year (1980), comprised the regional distribution of simulated pumpage because the pumpage used to calibrate each subregional model was from different years. Hydrologists chose the pumpage data considered the most accurate or most representative of steady-state conditions for their subregional simulations.

The precise distribution of pumping that occurred during the water-level measurements is unknown, and the degree to which the measured water levels approached the steady-state water levels associated with the pumping rates is also unknown. Seasonal agricultural pumpage, a large part of the stress on the system in peninsular Florida, is particularly difficult to estimate.

Simulation of 1980 conditions is better in coastal Georgia than in the other two heavily pumped areas of the aquifer system. One reason is that much of the coastal Georgia pumping is industrial and its rate and areal distribution are more accurately known than those of agricultural pumping. Also, industrial pumping tends to be more constant throughout the year rather than seasonal as is agricultural pumping. Hence, the aquifer system is more likely to be closer to a steady-state condition in coastal Georgia than elsewhere.

The simulation of 1980 conditions in south Florida is poor because the model's surficial aquifer-upper confining unit-Upper Floridan configuration oversimplifies a more complex hydrogeologic framework there. In the model, a thick intermediate aquifer system of unknown extent composed of three confined limestone aquifers of Miocene age is lumped into the upper confining unit (Meyer, in press). Within the Upper Floridan itself, Meyer (in press) noted that distinct and separate permeable zones exist, as indicated by changes in head, water quality, and temperature with depth. Additionally, more than one-half the thickness of the Floridan is lowpermeability carbonate rock that effectively "isolates" permeable zones within both the Upper and Lower Floridan aquifers. Vertical leakage to sustain 1980 pumpage from the Upper Floridan in south Florida (virtually all from partially penetrating wells) comes from the intermediate aquifer system and from nonpumped permeable zones within the Upper Floridan adjacent to the pumped zones. These sources of water are not simulated by the regional model, which simulates the Upper Floridan as a single layer. To improve simulation of the system in south Florida, a more detailed breakdown of aquifers and confining units in the model would be required, as well as more and better pumping data for each aquifer. The information to do this currently does not exist.

Upper Floridan aquifer discharge to a large number of springs and several streams is a major part of the flow system. In addition to the predevelopment potentiometric surface, discharges to springs and streams were used as known data in calibration of the predevelopment flow model. The discharges used are either recent measurements or estimated values. Regionally, discharge to springs and streams has been reduced very slightly by ground-water development; almost all appreciable pumping has been and is away from the areas where springs exist and aquifer discharge to streams occurs. Long-term records (more than $50 \mathrm{yr}$ ) of major springs do not show reductions in discharge with time. Even so, a presumably small but unknown amount of error has been incurred by the flow model because recent discharge data were used to calibrate the predevelopment model. When recent pumping was simulated by the flow model, total discharge to springs and streams dropped by 4.5 percent. This change is less than the error of measurement for most spring discharges. The 4.5-percent reduction in simulated aquifer discharge to springs and streams is also less than the modeling error in simulating predevelopment discharge to springs and streams. The weighted average modeling error in simulating individual springs, groups of springs, and (or) discharge to surface water bodies in the calibrated model was about 10 percent. Simulated total predevelopment discharge to springs, streams, and surface-water bodies was 98 percent of the estimated actual predevelopment total.

\section{HYDROLOGIC SETTING}

The hydrologic components that ultimately determine movement of water through the Floridan aquifer system are rainfall, runoff, and evapotranspiration. Rainfall is approximately balanced by runoff and evapotranspiration within the land area underlain by the Floridan aquifer system ("approximately" balanced because a relatively small part of the rainfall that recharges the Floridan aquifer system discharges offshore to the ocean, rather than on land to become part of evapotranspiration or runoff). This same balance existed before ground-water development in the Floridan occurred. Pumping induces recharge to or reduces natural discharge from the Floridan, which causes capture from runoff and evapotranspiration; but the water withdrawn that does not become part of a product ultimately returns to the hydrologic system. 
The impact of pumping on the regional hydrologic components is minimal. Total pumpage apportioned over the land area of the Floridan aquifer system is less than $1 \mathrm{in./yr}$. Average rainfall today is probably the same as it was during the 10,000 yr or so before ground-water development. In all probability, man's activities have not appreciably altered the overall evapotranspiration rate. Therefore, the assumption that the current regional average rate of runoff is about the same as it was prior to ground-water development is reasonable. Although local changes have undoubtedly occurred, the regional hydrologic setting is believed to be basically unchanged from predevelopment time. The discussion of the hydrologic setting that follows pertains to both current and predevelopment conditions unless otherwise noted.

\section{RAINFALL}

Long-term average rainfall on the land underlain by the Floridan aquifer system ranges from a low (excluding the Florida Keys) of about 45 in./yr at Abbeville in Wilcox County, Ga., to a high of about $68 \mathrm{in} . / \mathrm{yr}$ at Robertsdale in Baldwin County, Ala. Plate 7, the areal distribution of rainfall (based on Thiessen polygons; Linsley and others, 1975), shows that lowest annual rates (50 in./yr or less) are generally concentrated in southeast Georgia. Highest annual rates $(60$ in./yr or more) occur in southeast Florida, western panhandle Florida, and south Alabama.

Long-term average rainfall over the regional area as a whole is about 53 in./yr. Yearly total rainfall varies greatly. In extremely wet years, many rainfall stations have recorded more than twice the amount measured in very dry years (Carter, 1969; Bradley, 1972).

The seasonal variation in rainfall differs in peninsular Florida from that elsewhere in the Floridan's area of occurrence. On the peninsula, generally more than half of the annual amount falls in the 4-mo period June through September (Bradley, 1972). Water levels on the peninsula are usually lowest at the start of the rainy season (mid-May) and highest at the end of the rainy season (late September-early October). Elsewhere rainfall in a normal year is characterized by two highs and two lows: the maximums occur in late winter or early spring and then again in midsummer. The seasonal minimum is in the fall with a secondary minimum occurring about May. In response, highest water levels in the major part of the regional area north of peninsular Florida generally occur in late winter or early spring, and lowest water levels usually occur in the fall.

\section{RUNOFF}

Long-term average runoff varies considerably over the regional area, as shown on plate 8 . It is well below
$10 \mathrm{in./yr}$ in karstic, internally drained basins where net discharge to streams from the Upper Floridan is low. It is well above 30 in./yr in basins where net Upper Floridan discharge to streams is appreciable.

Low basin runoff values do not necessarily indicate low Upper Floridan discharge to streams. This is why the term "net" Upper Floridan discharge is used above. For example, a basin in north Florida drains part of the Suwannee River through Suwannee County where gaged runoff averages 7 in./yr. At least 13 known springs in the basin contribute about $800 \mathrm{ft}^{3} / \mathrm{s}$ to the Suwannee. However, reaches of the river within the basin also lose water to the Upper Floridan, so the net Upper Floridan discharge to the Suwannee between the upstream and downstream gages of the basin is about $450 \mathrm{ft}^{3} / \mathrm{s}$. Similarly, high basin runoff values do not always imply high Upper Floridan discharge to streams. Runoff is relatively high in the basins along the updip limit of the system in Alabama and far-west panhandle Florida, primarily because rainfall averages at least $10 \mathrm{in} . / \mathrm{yr}$ more there than in most of the rest of the regional area.

In several karstic basins of northwest Florida where the Upper Floridan is mostly unconfined, surface runoff is nearly zero. In those basins, virtually all of the gaged runoff is base flow from the Floridan; thus, runoff values in inches per year from topographically delineated surface-water basins are not meaningful in the traditional sense of implying a rate of runoff from a known land-surface area. The runoff figures are strongly influenced by the size of the basins. Many square miles of noncontributing drainage area lowers computed runoff.

Two more common factors that cause variability in runoff among basins are topography and the proximity of the water table to land surface. Flat, swampy basins tend to have less runoff than adjacent basins with more relief and less swampland. Also, the basin runoff values themselves are not strictly comparable because the periods of record from which the figures were computed are different. The entire period of record for all gaging stations with more than $10 \mathrm{yr}$ of record (for basins greater than $100 \mathrm{mi}^{2}$ with a few exceptions) was used to prepare plate 8 rather than selecting a period of record, say 1941-70, and using only those stations for which complete records for that period existed. Use of all stations with at least $10 \mathrm{yr}$ of record provided more complete regional coverage, at the expense of strict comparability among the basin figures.

Long-term average runoff from the land area of the Floridan is estimated to be about 16 in./yr. On the average over the regional area, more runoff will occur from discharge areas of the Floridan aquifer system than from its recharge areas, for two reasons: (1) where 
the vertical gradient in the aquifer system is upward (discharge areas), discharge from the Upper Floridan must ultimately add to either runoff to streams or evapotranspiration and (2) in discharge areas, rejected recharge (water that would have leaked to the Upper Floridan in recharge areas) must leave the system as runoff or evapotranspiration.

\section{EVAPOTRANSPIRATION}

Of the three basin hydrologic processes, evapotranspiration is the most difficult to quantify. Unlike the maps showing regional rainfall and runoff, the map of regional evapotranspiration shown on plate 9 is not based on field measurements. The basis for estimating the evapotranspiration rates shown is a method using temperature and precipitation developed by Holdridge (1967) and later described and used in Florida by Dohrenwend (1977). The central variable for the estimation of evapotranspiration by this method is "biotemperature" defined as the annual sum of hourly temperatures between $32^{\circ} \mathrm{F}$ and $86^{\circ} \mathrm{F}$ divided by the number of hours in the year, with temperatures below $32^{\circ} \mathrm{F}$ and above $86^{\circ} \mathrm{F}$ added in as $32^{\circ} \mathrm{F}$. Holdridge first linearly relates the biotemperature for a given site to potential evapotranspiration, which he defines as the quantity of water (expressed as a depth) that would be given up to the atmosphere within a zonal climate and upon a zonal soil by the natural vegetation of the area, if sufficient but not excessive water were available during the growing season. (Thus, by the Holdridge method, actual evapotranspiration estimates are for losses from land surface only.) Estimated actual evapotranspiration can then be obtained by the use of a nomogram that relates the potential evapotranspiration ratio (potential evapotranspiration divided by precipitation) with a ratio of actual evapotranspiration to potential evapotranspiration. Dohrenwend (1977) computed biotemperatues for 21 stations in Florida from 5 yr of temperature record.

Estimates of actual evapotranspiration (pl. 9) use the method of least squares initially to obtain a linear statistical relation between the mean-annual temperature and the biotemperature for the 21 stations. Two tests were made on the linear correlation model thus determined to verify that the relation between meanannual temperature and biotemperature was indeed linear. The test results indicate a linear relation.

Biotemperatures were then calculated for the rainfall stations for which mean-annual temperature data were available (96 of the 154 rainfall stations). Estimates of actual evapotranspiration at the 96 stations were then determined using the calculated biotemperatures and the linear statistical relation.
To construct the regional evapotranspiration map shown on plate 9 , the surface-water basin map was overlain on an estimated land-surface evapotranspiration map constructed on the basis of biotemperature, then overlain on a map that was constructed on the basis of lake evaporation as discussed by Kohler and others (1959). The percentage of land area, open-water area, and swamp area in each basin (or combination of basins and coastal areas shown on pl. 9) were then estimated. The final basin evapotranspiration estimates of plate 9 are weighted averages of the land, open-water, and swamp values; evapotranspiration from swamps was assumed to be 90 percent of the open-water value.

Using this method for estimating regional evapotranspiration is conjectural; however, it provided estimates for central Florida that are similar to some determined in previous studies (Parker and others, 1955; Pride and others, 1966). But more important, the method provided a means to develop estimates in a consistent manner over the entire Floridan area.

Estimated evapotranspiration ranges from a low of $31 \mathrm{in} . / \mathrm{yr}$ in the several counties of south-central Georgia that comprise the northernmost part of the regional area, to a high of $46 \mathrm{in} . / \mathrm{yr}$ in the vast swampy areas of south Florida. (Note: The circular area labeled 50 in./yr on plate 9 overlies Lake Okeechobee.) Average rates generally increase from north to south primarily because temperatures and the growing seasons increase from north to south. At a given latitude, more evapotranspiration will occur from areas where the water table is close to land surface than from welldrained areas with relatively deep water tables.

Long-term average evapotranspiration from the regional area is estimated to be about 37 in./yr. All other conditions being equal, more evapotranspiration will occur from discharge areas of the Floridan aquifer system than from recharge areas, for the same previously mentioned reasons that runoff is greater in discharge areas.

\section{HYDROLOGIC BUDGET}

The estimated hydrologic budget for the approximately $94,000 \mathrm{mi}^{2}$ of the Floridan aquifer system's onshore area of occurrence for predevelopment and current conditions is summarized in figure 17. Fifty-three inches per year of rainfall are approximately balanced by $37 \mathrm{in} . / \mathrm{yr}$ of evapotranspiration and $16 \mathrm{in}$./yr of runoff (less than $1 / 2$ in./yr, apportioned over the regional onshore area, discharges offshore to the ocean).

To estimate the average amount of recharge to the Floridan, the overall hydrologic budget must be separated into a budget for the recharge area and a budget for the discharge area. The estimated hydrologic budgets for the predevelopment and the current 


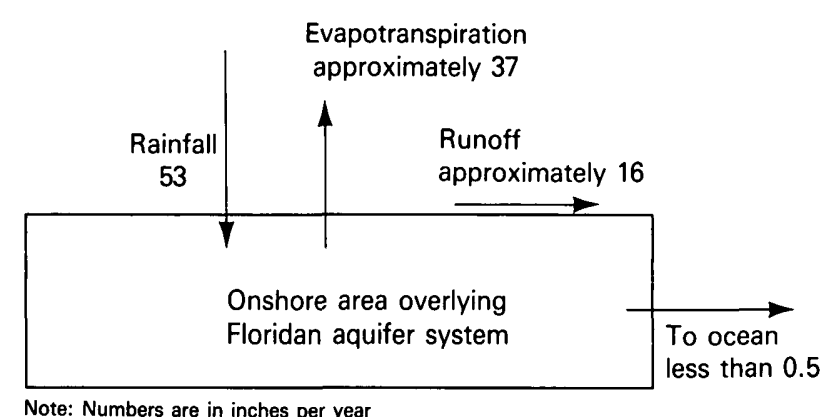

FIGURE 17.-Components of the regional hydrologic budget.

recharge areas and the onshore discharge area are shown in figure 18.

In the recharge area, rainfall is assumed to be 53 in./yr. No Floridan aquifer discharge occurs, and rejected recharge is less than in the discharge area. Thus, runoff in the recharge area will be less than the estimated $16 \mathrm{in}$./yr regional average runoff. Based on streamflow records and regional physiography, the predevelopment and current runoff (including overland runoff and ground-water runoff from the surficial aquifer) over the regional recharge area is estimated to be about 12 in./yr. Because no Floridan aquifer discharge occurs in the recharge area and rejected recharge is less than that over the region as a whole, evapotranspiration will also average slightly less in the recharge area. The authors' estimate of average predevelopment and current evapotranspiration from the regional recharge area is $36 \mathrm{in} . / \mathrm{yr}$. The sum of runoff and evapotranspiration is thus $48 \mathrm{in}$./yr or about $5 \mathrm{in}$./yr less than annual rainfall. Therefore, the surplus of $5 \mathrm{in} . / \mathrm{yr}$ is the estimated average long-term recharge to the Floridan aquifer system. The present rate of recharge is still about $5 \mathrm{in}$./yr; however, simulation indicates that the area over which recharge occurs has enlarged and the discharge area has shrunk.

The increase in size of the recharge area and corresponding decrease in size of the discharge area cause some differences in the hydrologic budget for the discharge area between predevelopment and current conditions. For the predevelopment situation in the onshore discharge area summarized in figure $18 B$, average rainfall is again assumed to be $53 \mathrm{in} . / \mathrm{yr}$. Total runoff in the discharge area includes the $12 \mathrm{in} . / \mathrm{yr}$ of overland and surficial-aquifer runoff plus two additional components: (1) runoff derived from that part of rejected recharge to the Floridan that does not become evapotranspiration and (2) runoff derived from that part of the Floridan discharge that does not become evapotranspiration.

\section{A, PREDEVELOPMENT} RECHARGE AREA

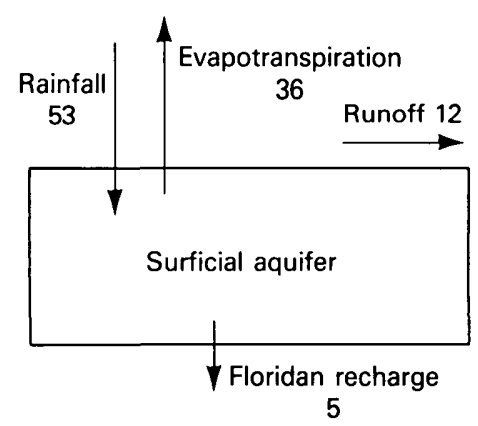

C, CURRENT RECHARGE AREA

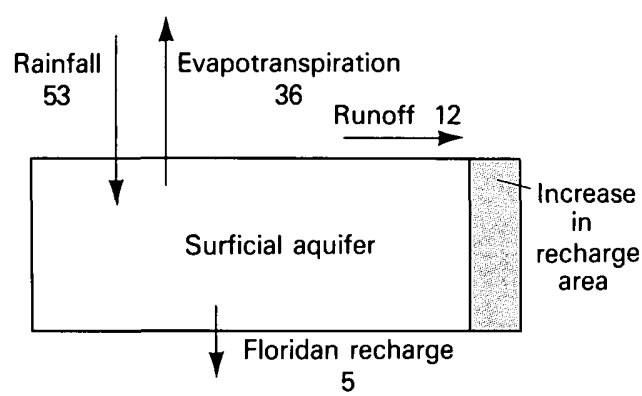

B, PREDEVELOPMENT ONSHORE DISCHARGE AREA

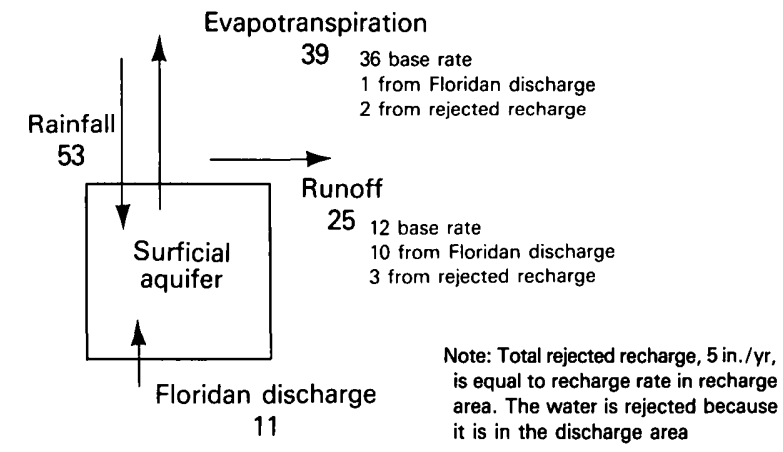

D, CURRENT ONSHORE DISCHARGE AREA

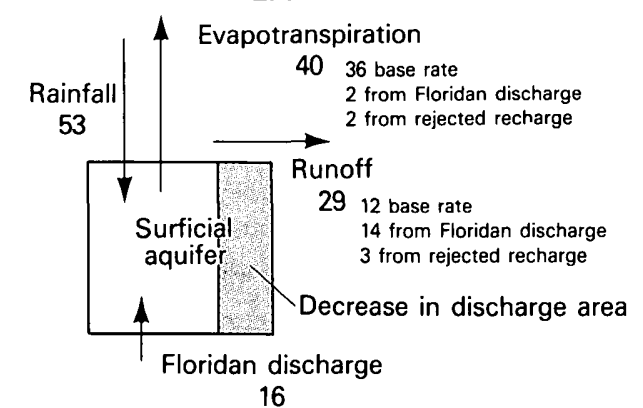

Note: Components are in inches per year. The sizes of the rectangles are approximately proportional to the sizes of the recharge and discharge areas

Figure 18.-Components of the regional hydrologic budget in $A$, predevelopment recharge area; $B$, predevelopment onshore discharge area; $\mathrm{C}$, current recharge area; and $D$, current onshore discharge area. 
If 60 percent of the $5 \mathrm{in} . / \mathrm{yr}$ rejected recharge becomes runoff (60 percent is an arbitrary estimate), an additional $3 \mathrm{in} . / \mathrm{yr}$ are added to the runoff. Discharge of the Floridan over the assumed predevelopment onshore discharge area is estimated from simulation to be about $11 \mathrm{in} . / \mathrm{yr}$. If 90 percent of this $11 \mathrm{in}$.yr becomes runoff (because, as discussed later in the report, about 90 percent of predevelopment discharge is spring flow and discharge to surface-water bodies), then $10 \mathrm{in}$./yr additional runoff is provided by Floridan discharge. Thus, estimated total runoff over the assumed predevelopmentonshore discharge area is $25 \mathrm{in}$./yr.

Evapotranspiration in the recharge area was estimated to be 36 in./yr. The same base rate occurs in the discharge area, plus another 2 in./yr from rejected recharge and an estimated $1 \mathrm{in}$./yr from Floridan discharge, for a total estimated predevelopment rate of $39 \mathrm{in} . / \mathrm{yr}$.

The major change due to development is a reduction in percentage of land area where Floridan discharge occurs from about 30 percent to about 20 percent (fig. $18 D$ ). Ground-water development has had little effect on total spring flow and Upper Floridan discharge to surface-water bodies, which constituted about 90 percent of discharge from the predevelopment aquifer system, and accounted for about 75 percent of discharge in 1980. Pumping has appreciably reduced diffuse upward leakage from the Upper Floridan, but diffuse upward leakage is a small part of the total discharge from the aquifer system. Because spring flow and discharge to surface-water bodies is largely unaffected by ground-water development, total Floridan discharge today is not appreciably more than it was before ground-water development. However, the area over which current discharge must be apportioned to obtain a rate in inches per year is only two-thirds its predevelopment size. Thus, when current discharge is apportioned over a discharge area that is about two-thirds its predevelopment size, the estimated discharge rate in inches per year increases about 5 in./yr over the estimated predevelopment rate of $11 \mathrm{in} . / \mathrm{yr}$ to $16 \mathrm{in} . / \mathrm{yr}$.

If, as in the predevelopment case, about 90 percent of the Floridan discharge becomes spring flow and discharge to surface-water bodies, then about 14 of the $16 \mathrm{in} . / \mathrm{yr}$ Floridan discharge becomes runoff. The two other components of current total runoff in addition to Floridan discharge (assumed to be the same as before development) are the base rate, $12 \mathrm{in} . / \mathrm{yr}$, and runoff from rejected recharge, $3 \mathrm{in}$./yr. Thus, current total runoff is estimated to be the sum of the three components, $29 \mathrm{in} . / \mathrm{yr}$.

If the remaining $2 \mathrm{in} . / \mathrm{yr}$ of Upper Floridan discharge that does not run off becomes evapotranspiration, then the estimated current evapotranspiration from the onshore discharge area increases $1 \mathrm{in} . / \mathrm{yr}$ over the predevelopment value of $39 \mathrm{in}$./yr. to $40 \mathrm{in}$./yr. As with runoff, this figure assumes that the two other components of evapotranspiration, $36 \mathrm{in}$./yr base rate plus 2 in./yr from rejected recharge, are the same as in predevelopment time.

Highest rates of recharge to the Floridan occur where maximum rainfall occurs along with minimum surface runoff and evapotranspiration. In some karstic basins of northwest Florida where the Floridan is mostly unconfined, surface runoff is virtually zero. In the area of these basins, the map of rainfall (pl. 7) shows that the long-term rate in inches per year is generally in the mid-50's. The map of evapotranspiration (pl. 9) shows that the long-term rate of this component in inches per year is generally in the mid-30's. The implication is that the long-term amount of water available to recharge the Floridan under the most favorable natural circumstances is somewhere around $20 \mathrm{in} . / \mathrm{yr}$, perhaps as high as $25 \mathrm{in}$./yr. However, very locally, in an area where a stream is losing water to the Floridan at a high rate for example, long-term recharge could exceed 20-25 in./yr.

\section{THE PREDEVELOPMENT FLOW SYSTEM}

The major features of the predevelopment flow system are illustrated by the estimated predevelopment potentiometric surface of the Upper Floridan aquifer shown on plate 4 . The potentiometric surface presented here is modified from the original version (Johnston and others, 1980). The changes, primarily in south Florida, panhandle Florida, and the outcrop area in Georgia, resulted from newly discovered data or reinterpretation of existing data.

The movement of water in the aquifer system is generally perpendicular to potentiometric-surface contours. The map shows that in South Carolina and Georgia, the direction of predevelopment flow is east and southeast from the topographically high outcrop areas toward the Atlantic coast and Florida. In Alabama and west Florida, flow is generally south from the outcrop areas toward the Gulf coast. In peninsular Florida, the general flow direction is from the central inland areas toward the Gulf and Atlantic coasts. The potentiometric surface thus implies that, in the predevelopment system, recharge occurs in the northern outcrop and peninsular inland areas and discharge occurs in coastal areas, which is true in a gross regional context.

The characteristic of the system that most strongly influences the distribution of natural recharge, flow, and discharge is the degree of confinement on the Upper Floridan aquifer. Closed-contour depressions and contours distorted as they cross streams indicate discharge from the Upper Floridan and typify unconfined and semiconfined aquifer conditions. Smooth, 
sweeping contours are associated with confined parts of the aquifer that are well "insulated" from surface drainage features. A comparison of the potentiometric surface with the map of confined/unconfined conditions (pl. 1) shows that the occurrence of highly distorted contours and closed-contour depressions along the northern outcrop and in northwest and central Florida generally coincides with unconfined and semiconfined areas on plate 1. Smooth, sweeping contours characterize the potentiometric surface in coastal Georgia and northeast Florida, south Florida, and far-west panhandle Florida, the principal confined areas.

The altitude of the potentiometric surface is also an indication of the degree of confinement in coastal areas. Generally, the altitude of the potentiometric surface is $10 \mathrm{ft}$ or less along most of the Gulf coast in central and northwest Florida, and the Atlantic coast in east-central Florida and South Carolina where the Upper Floridan is unconfined and semiconfined. The predevelopment potentiometric surface is considerably higher in coastal parts of the three principal confined areas of the aquifer. Logically, heads would adjust to lower equilibrium levels in unconfined and semiconfined areas of the aquifer where resistance to discharge is less.

\section{RECHARGE, DISCHARGE, AND CIRCULATION}

Before development, the flow system was in a state of long-term dynamic equilibrium in which natural recharge to the Floridan aquifer system was balanced by natural discharge. Estimates indicate that about $67,000 \mathrm{mi}^{2}$ was recharge area and about $27,000 \mathrm{mi}^{2}$ was land discharge area (estimated total predevelopment discharge area, including offshore area, is 55,000 $\mathrm{mi}^{2}$ ). The total predevelopment recharge, and therefore discharge, simulated by the regional flow model was about $21,500 \mathrm{ft}^{3} / \mathrm{s}$. This is equivalent to $4.4 \mathrm{in}$./yr over the recharge area, slightly less than the estimate of $5 \mathrm{in} . / \mathrm{yr}$ determined from analysis of the regional hydrologic budget. Simulated recharge and discharge are less than the "real world" value, because the regional flow model is of a scale that precludes accounting for all recharge and discharge. The size of the grid blocks $\left(64 \mathrm{mi}^{2}\right)$ results in some of the local recharge and discharge not being simulated because some recharge and discharge occurs wholly within $64 \mathrm{mi}^{2}$ areas. Thus, recharge and discharge obtained from any digital model is scale dependent, and the value of $21,500 \mathrm{ft}^{3} / \mathrm{s}$ is considered to be slightly lower than the actual value of predevelopment recharge and discharge.

The dominant feature of the predevelopment Floridan flow system is discharge from Upper Floridan aquifer springs. The concentration of 27 first-magnitude springs (discharge exceeds $100 \mathrm{ft}^{3} / \mathrm{s}$ ) in Florida is unique in the United States. Individual spring discharges range from near zero to about $1,600 \mathrm{ft}^{3} / \mathrm{s}$. Most springs are concentrated along major streams and along the coast of westcentral Florida. Today, the combined average discharge from about 300 known Upper Floridan aquifer springs, almost all of which are in Florida, probably ranges between 12,500 and $13,000 \mathrm{ft}^{3} / \mathrm{s}$. Rosenau and others (1977, p. 1) concluded that spring flow statewide in Florida had not changed in the 30 yr preceding 1977 , although reduced flow from some springs has been documented. Comparison of current mean discharge of 24 of Florida's largest springs with measurements made in or prior to the early 1930's (Stringfield, 1936, p. 155, 156) showed virtually no decrease in flow. Thus, the total predevelopment spring flow assumably was not significantly greater than it is today.

In addition to discharge from springs, direct aquifer discharge to streams and lakes is appreciable. About $7,000 \mathrm{ft}^{3} / \mathrm{s}$ discharges to streams and lakes, in addition to spring flow, based on simulation. The locations of Floridan aquifer springs and estimated areas of appreciable aquifer discharge to streams and lakes used in simulating the flow system are shown on plate 10 . Table 4 is a tabular listing of the springs and surface-water bodies receiving aquifer discharge that are identified by number on plate 10. Not shown or listed are springs with discharges less than $1 \mathrm{ft}^{3} / \mathrm{s}$ or reported submarine springs for which no reliable discharge measurements are available.

Springs and aquifer discharge to streams and lakes, nearly all of which occurs in unconfined and semiconfined areas (pl. 1), accounted for about 88 percent of the $21,500 \mathrm{ft}^{3} / \mathrm{s}$ simulated predevelopment discharge, or about $19,000 \mathrm{ft}^{3} / \mathrm{s}$. Diffuse upward leakage, which occurs primarily in confined areas, accounted for the remaining 12 percent of the total simulated predevelopment discharge, or about $2,500 \mathrm{ft}^{3} / \mathrm{s}$.

Most of the recharge necessary to sustain spring flow and aquifer discharge to streams and lakes occurred (and to this day occurs) relatively close to springs and areas of point discharge to surface-water bodies. Plate 11 is a map of the estimated predevelopment recharge to and discharge (as diffuse upward leakage) from the Upper Floridan; the locations of springs and areas of point discharge to surface-water bodies are also shown. The proximity of areas of high recharge (10-20 in./yr) to springs and other point discharges is apparent. This proximity of high recharge to high discharge indicates a vigorous and well-developed shallow flow system in the unconfined and semiconfined parts of the Upper Floridan aquifer.

\section{UNCONFINED AND SEMICONFINED AREAS}

The predominance of shallow ground-water flow in limestone under water-table conditions has been 
TABLE 4.-Observed Upper Floridan aquifer discharge from springs and estimated Upper Floridan aquifer discharge to surface-water bodies ${ }^{1}$

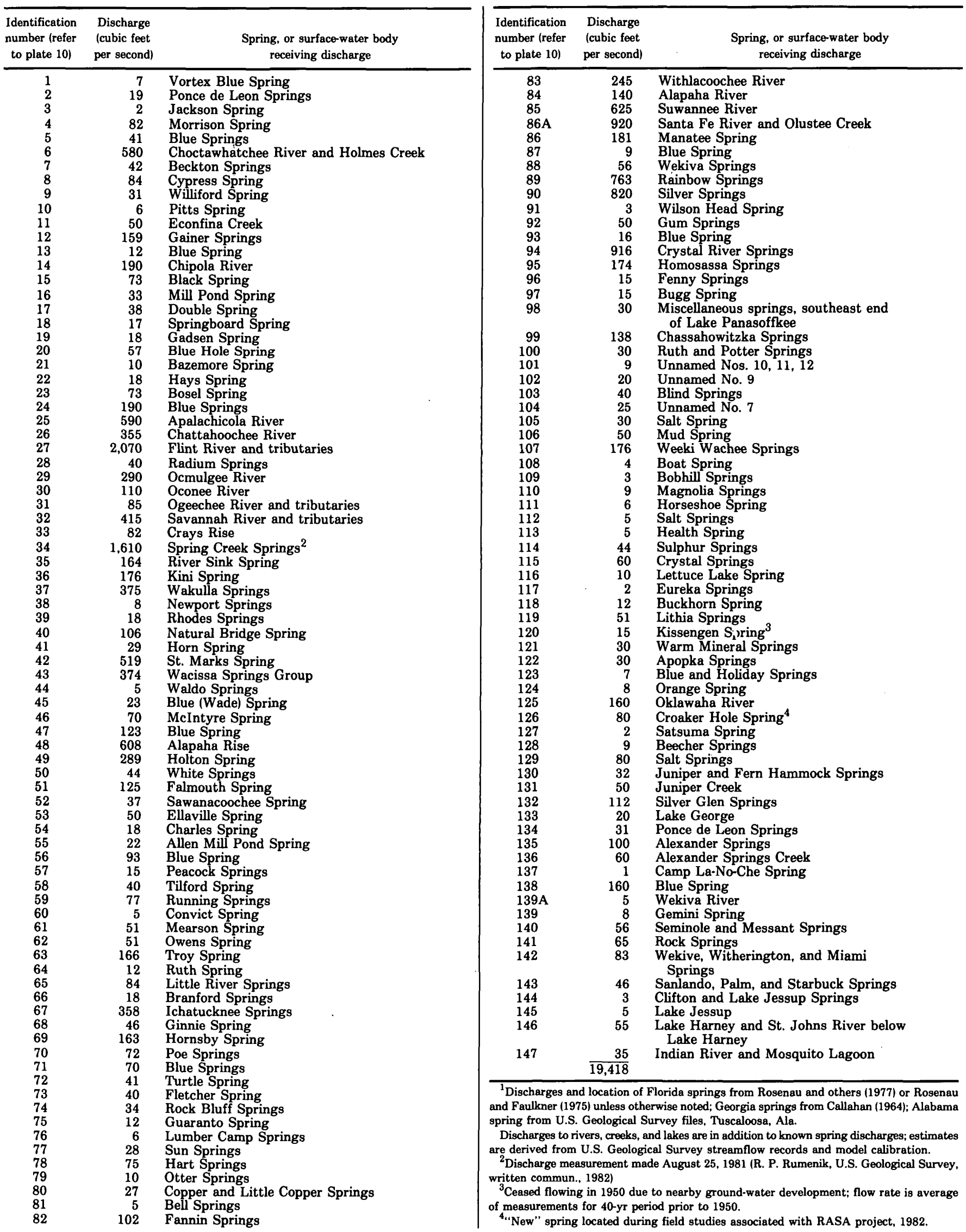


recognized by many previous investigators. Stringfield $(1966$, p. 79) concluded that most solution would occur in the upper part of the zone of saturation, in the part of the aquifer where continuous circulation is the most vigorous. He further stated that Piper (1932, p. 73) suggested that the most rapid dissolution of limestone occurs in the zone bracketed by the seasonal high and low of the water table and that Theis $(1936, p .44)$ concluded that the greatest amount of solution takes place near the water table. Faulkner (1973, pp. 73-77), in his study of the geohydrology of the Cross-Florida Barge Canal area, presented a thorough discussion of the factors that indicate very active shallow circulation in the vicinity of Silver Springs and Rainbow Springs, two of Florida's largest springs. Sinclair $(1978$, p. 10) stated that an integrated subsurface drainage system has developed at or near the water table in the coastal springs-Withlacoochee River area of west-central Florida that is similar to a surface stream; that is, with tributaries (solution channels) increasing in size as they decrease in number downgradient from recharge areas toward coastal springs.

In a review of karst hydrology, LeGrand and Stringfield (1973, p. 101) noted, among other salient characteristics, that "coarse-textured" carbonate aquifers have (1) a channel or artery network type of permeability, especially near the water table and (2) rapidly decreasing overall permeability with increasing depth below the water table.

Rhoades and Sinacori (1941) hypothesize that increasing shallow ground-water flow and decreasing deep ground-water flow is the natural progression of a limestone circulation system over geologic time. Initially, if a limestone system had intersecting joint patterns of more or less uniform distribution, its overall flow pattern would be roughly like that proposed by Hubbert $(1940$, p. 930) for flow between points of recharge and discharge in uniformly permeable material. This type of flow pattern favors more aggressive solution along the shorter, shallower flow paths; this is because the water there, owing to its relatively short residence time, generally is richer in carbon dioxide and more undersaturated with respect to calcium carbonate than water deeper in the limestone. Thus, the more aggressive solution leads to the formation of large-diameter conduits and more direct connection to points of discharge in the upper parts of the aquifer. Ultimately, these large conduits develop into "master" conduits by the coalescence of adjacent channels, capable of carrying very large lateral flows, and result in greatly decreased deep circulation.

Geochemical evidence shows that shallow flow is more active than deep flow throughout the aquifer system. Water produced from the set of about 400 wells chosen to characterize the major-ion chemisty of the Upper Floridan, each open to more than half the total thickness of the aquifer, tends to be higher in dissolved solids than the water from shallow wells that penetrate the aquifer only a few tens of feet (Sprinkle, 1982d). A mapped area of high-sulfate concentration (Sprinkle, 1982a) is overlapped by an area of major spring discharge and high recharge in Alachua and Marion Counties, Fla. Sprinkle (in press) concluded that this seemingly anomalous situation exists because sluggish freshwater flow through the deeper parts of the Upper Floridan has been insufficient to dissolve the sulfate minerals present. Sprinkle's sulfate map is based on analyses of samples from wells penetrating more than half the aquifer thickness; the high recharge and spring discharge in Alachua and Marion Counties, Fla. portrayed on plate 11 occurs above the zone in the Upper Floridan where high sulfate concentrations exist.

The patterns of natural ground-water flow that evolved within the Floridan aquifer system before ground-water development are similar to those proposed by Toth (1963). Toth described ground-water flow as being apportioned among three types of flow systems: the local, intermediate, and regional systems. He defined a local system of ground-water flow as the direct result of basin topography. A local flow system has its recharge area at a topographic high and its discharge area at an immediately adjacent topographic low. In Toth's intermediate flow system, circulation is deeper than in a local system, and one or more topographic highs and lows may occur between areas of recharge and discharge. His regional flow system, deeper still, is one in which its recharge area occupies the regional ground-water divide and its discharge area lies at the down-gradient terminus of the regional basin.

Topography and drainage characteristics in unconfined and semiconfined parts of the Floridan aquifer system vary widely. In the northern outcrop area east of the Dougherty Plain in Georgia, topographic relief is great compared to flat coastal areas. Sandy hills and valleys characterize the eroded and weathered Miocene deposits and residuum. A classic dendritic drainage pattern has evolved in which progressively larger surface streams coalesce and ultimately join one of the four major streams that cross the outcrop. An example of these features in the Ocmulgee River area is shown in figure 19. At the other end of the spectrum are the karstic spring areas of north-central and northwest peninsular Florida. Topographic relief is generally less and more subdued than that associated with the northern outcrop area. Surface drainage is virtually nonexistent. Drainage is internal until it reaches springs or the major streams that are well incised into Upper Floridan limestone. Figure 20 shows topography and 


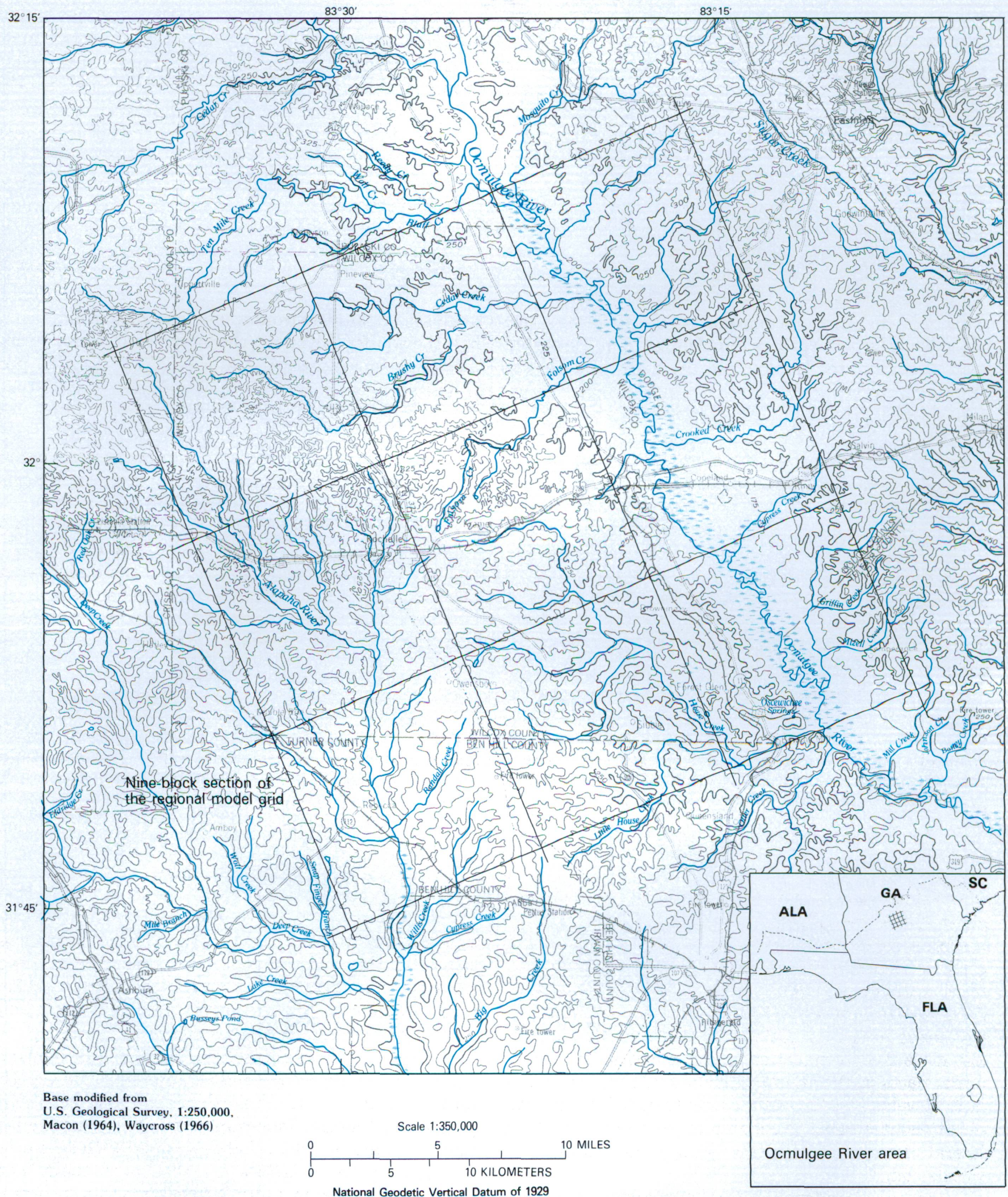

FIGURE 19.-Typical pattern of topography and drainage in Ocmulgee River area; Floridan aquifer system unconfined or semiconfined. 


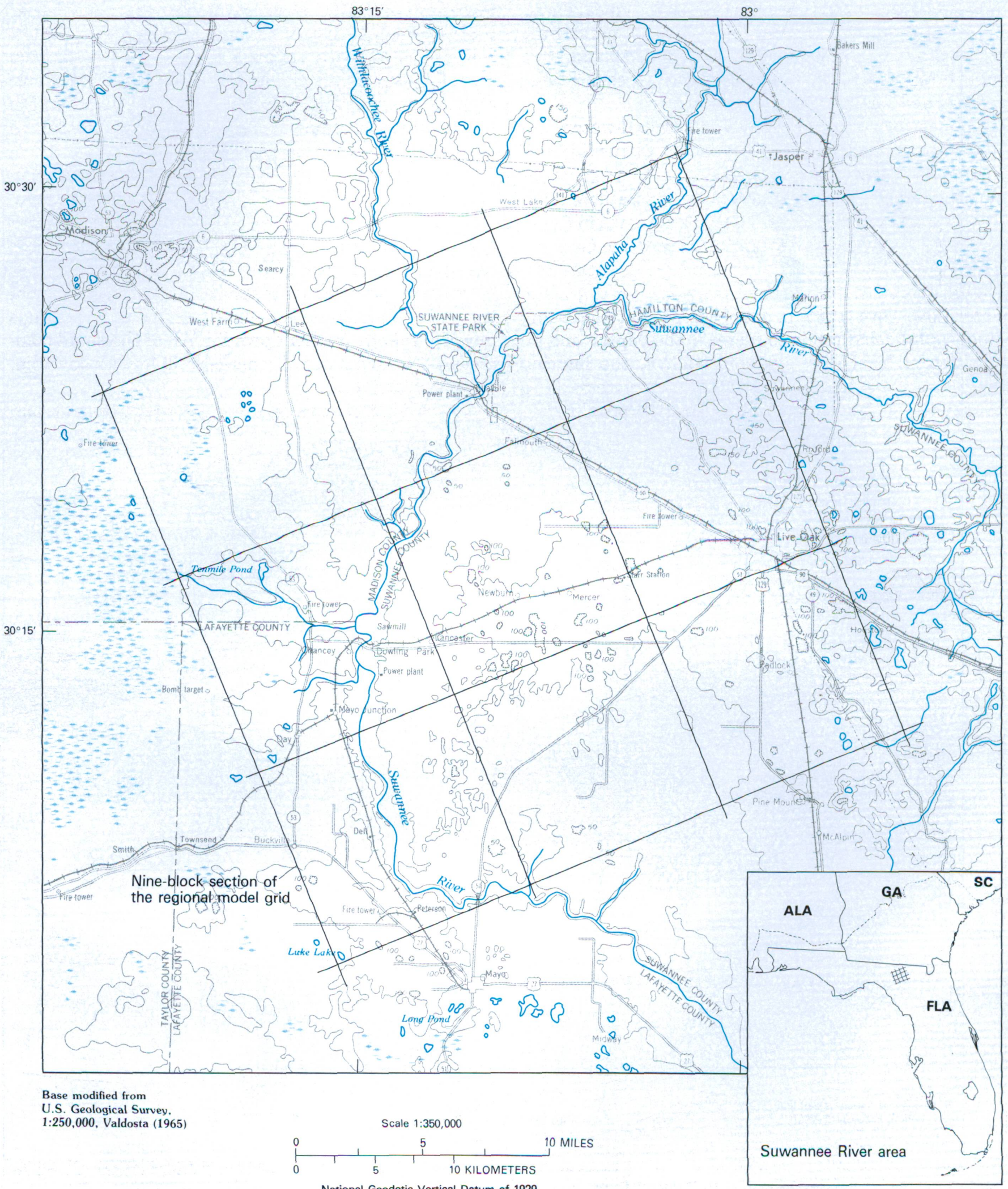

FIGURE 20.-Typical pattern of topography and drainage in Suwannee River area; Floridan aquifer system unconfined or semiconfined. 
drainage around the Suwannee River, a typical example of an internally drained karst area. A part of the regional model grid is overlain on figures 19 and 20 to show how the scale of individual model blocks relates to drainage features.

Application of Toth's concept of ground-water flow suggests that distinctly different patterns of flow characterize areas of the Floridan similar to those shown in figures 19 and 20. Idealized illustrations of the two distinct patterns of circulation are shown in figure 21. In the hilly outcrop area of the Floridan in Georgia, surface drainage is well developed and local flow systems probably account for the major part of groundwater flow. Toth $(1963$, p. 4808) stated that increasing topographic relief tends to increase the depths and intensities of local flow systems; and, in the limiting theoretical case where only local flow systems (in a homogeneous, isotropic aquifer) occur, approximately
90 percent of the total recharge never penetrates deeper than about 30 percent of the aquifer thickness (p. 4811). Thus, most of the local flow occurs within the surficial aquifer overlying the Upper Floridan aquifer in the outcrop area of Georgia. If this is so, only a fraction of the total recharge actually enters the Upper Floridan to become intermediate and regional flow.

Intermediate and regional flow in the outcrop area in Georgia is more complicated than Toth's conceptualization in that the aquifer system receives recharge from clastic sediments below as well as from above. Some part of the intermediate flow derived from both sources discharges to the more deeply incised streams within the outcrop area, and some part discharges as diffuse upward leakage further downdip. All of the small component of regional flow discharges still further downdip, primarily offshore.

In the karstic spring areas of north-central and

\section{EXPLANATION}

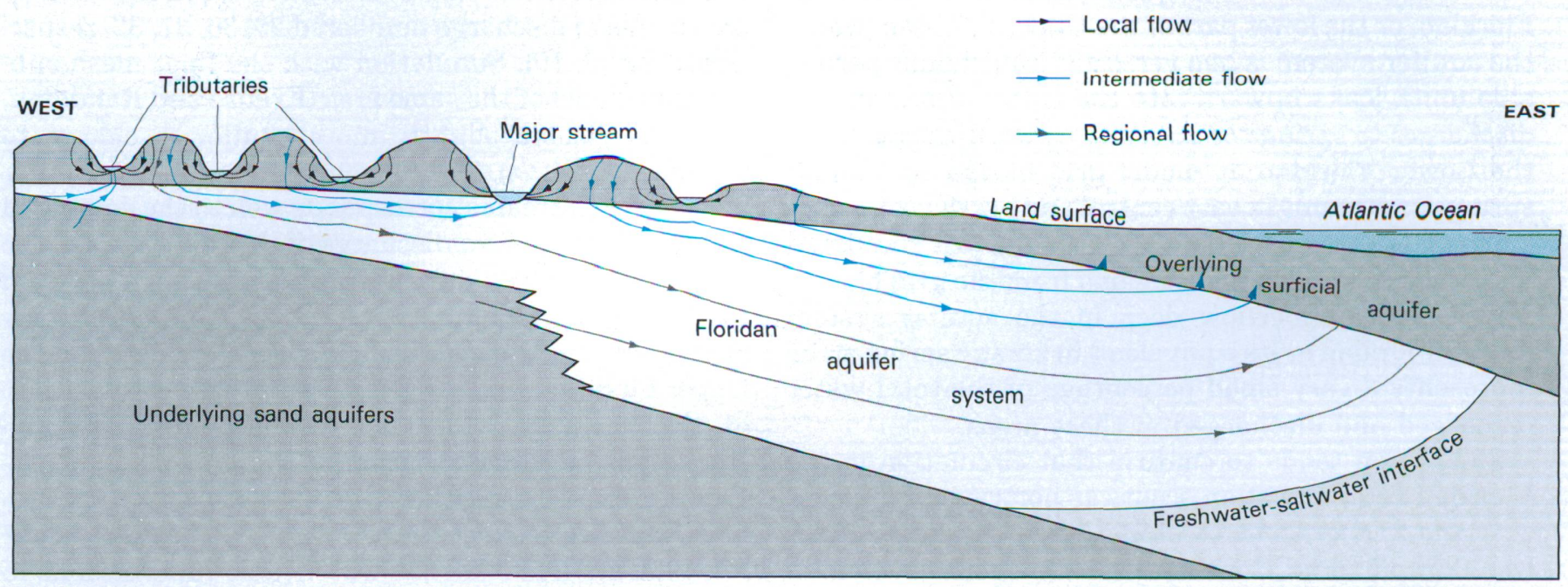

A, Outcrop in Georgia to the Atlantic Ocean

WEST

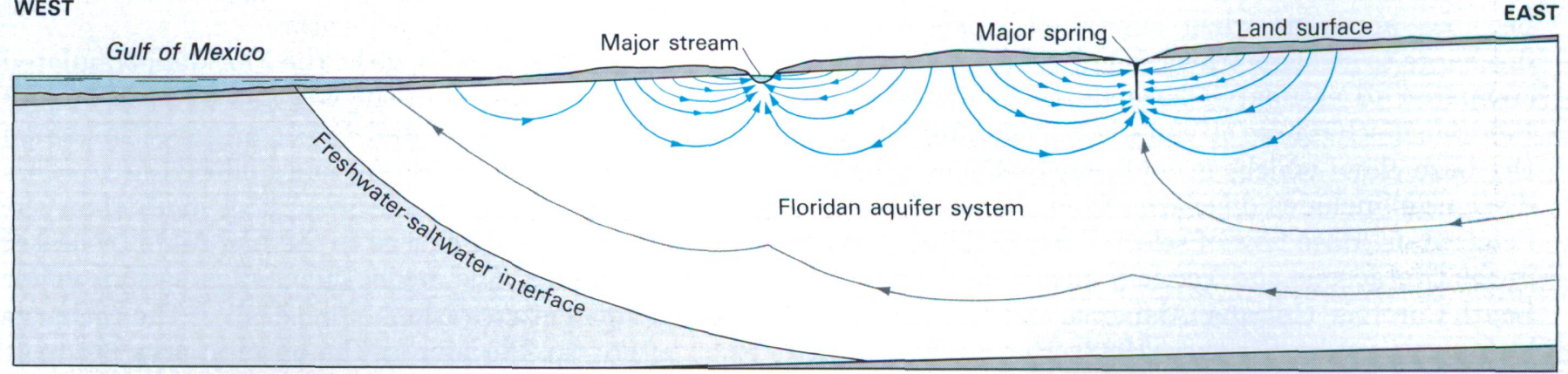

B, North-central Florida springs area to the Gulf Coast

FigURE 21.-Idealized flow patterns in the Floridan aquifer system. 
northwest peninsular Florida as portrayed in figure $21 B$, Toth's local flow systems generally do not exist. Even where hilly Miocene deposits occur, the very high permeability of the underlying limestone usually results in a flat water table. The shallow subsurface arteries connecting springs and major streams to adjacent recharge areas are much less influenced by topography. Thus, flow paths are generally longer and intermediateflow systems dominate.

Faulkner (1973, p. 75) documented the lack of localflow systems in the Rainbow Springs-Silver Springs drainage areas and labeled ground-water flow toward these large springs as intermediate in Toth's classification scheme. He further stated (p. 76) that, based on average sulfate concentrations near the top of the aquifer (top of Upper Floridan), near the bottom of the aquifer (middle of Lower Floridan), and in Silver Springs, the spring water is a mixture of about 92-percent shallow water and 8-percent deep water. Regional simulation showed that, beneath all but the smallest springs or streams, some water from the Lower Floridan, or the lower part of the Upper Floridan (where the aquifer system is one vertically continuous permeable unit), leaks upward into the Upper Floridan and discharges to springs or streams. Upward leakage from the Lower Floridan at model grid blocks containing springs or streams in east-central and northwest peninsular Florida was about 7 percent of simulated discharge to springs and streams from the grid blocks. The regional underflow deep in the aquifer system (Lower Floridan or its equivalent) in karstic spring areas represents a very small percentage of the total water recharged and discharged in these areas.

Simulation tends to confirm that circulation in the Floridan aquifer system occurs as portrayed in figures $21 A$ and $21 B$ or some combination of these two idealized flow patterns. Consider first the aquifer system in the outcrop area in Georgia east of the Dougherty Plain (figs. 19 and 21A). The existence and dominance of local flow systems that do not reach the Upper Floridan becomes apparent when simulated Upper Floridan discharge to streams traversing the Georgia outcrop is compared to estimated base flow. Simulated Upper Floridan discharge to streams is considerably less than the base flow, which, in addition to Upper Floridan discharge, includes discharge from the overlying surficial sands. Base flow of selected unregulated streams in the Cretaceous and Tertiary clastic outcrop area of South Carolina, Georgia, Alabama, and Mississippi has been analyzed by Stricker (1983). Her study included computation (by hydrograph separation) of base flow to streams in eight basins of the Georgia Coastal Plain between the Fall Line (inner margin of the Coastal Plain) and the Floridan aquifer outcrop. She concluded that discharges at the 65-percent duration point on flowduration curves were good estimates of the mean annual base flow. The aquifers contributing base flow in the area between the Fall Line and the Floridan outcrop studied by Stricker (1983) are composed primarily of sand whereas aquifers contributing base flow in the Floridan outcrop area are sand and limestone. However, long-term average runoff is virtually the same in the two areas (about 13 in./yr). Flow-duration characteristics of streams draining basins in the Floridan outcrop assumably are similar to those of streams draining nearby basins in the Stricker study. If this assumption is valid, then discharge at the 65-percent point on flowduration curves for unregulated periods at gaging stations on each of the four major rivers in the Floridan outcrop area would provide a reasonable estimate of the base flow. The base flow thus determined is about 8 in./yr.

The predevelopment regional model simulated at total of $900 \mathrm{ft}^{3} / \mathrm{s}$ of aquifer discharge to the Ocmulgee, Oconee, Ogeechee, and Savannah Rivers in the outcrop area (areas of discharge numbered $29,30,31,32$, respectively, on pl. 10). Simulation with the finer mesh subregional model of the same area (Krause and Randolph, in press) yielded slightly more aquifer discharge to streams $\left(960 \mathrm{ft}^{3} / \mathrm{s}\right)$. The $900-960 \mathrm{ft}^{3} / \mathrm{s}$ range of aquifer discharge to streams corresponds well to the combined annual 7-day low-flow discharge of the four rivers in the outcrop area. The 7-day low-flow discharge is believed to include a minimal contribution from local flow systems in the Miocene surficial deposits overlying the Upper Floridan, while at the same time preserving most of the "average" Floridan discharge (Krause and Randolph, in press). Discharge to streams from the Floridan tends to vary less than discharge from the surficial deposits because the artesian head changes in the Floridan are less than the water-table functuations in the surficial deposits. The regional model implicitly confirms the existence and dominance of local flow systems by requiring less discharge to streams than total base flow to obtain the best calibration.

Predevelopment recharge to the Floridan, simulated by the regional model in the Georgia outcrop area of the Ocmulgee, Oconee, and Ogeechee, and Savannah River basins, from overlying and underlying aquifers is about $1,050 \mathrm{ft}^{3} / \mathrm{s}$, not a great deal more than the simulated aquifer discharge to the four major rivers of the outcrop area. The model thus indicates that under predevelopment conditions almost all of the recharge that enters the Floridan in the outcrop area becomes intermediate flow that discharges to one of the major streams. A minor part of the recharge becomes regional flow that discharges as diffuse upward leakage downdip of the outcrop area. 
In contrast, consider now the aquifer system in the karstic area around the Suwannee River (figs. 20 and $21 B$ ). Tributary streams and local flow systems are practically nonexistent. Virtually all of the river discharge is base flow from the Upper Floridan. Simulated aquifer discharge to the Suwannee River with a calibrated model should therefore be about the same as long-term average discharge. In the Suwannee River basin $^{1}$, the long-term average discharge is about $5,100 \mathrm{ft}^{3} / \mathrm{s}$. The regional model simulated $5,017 \mathrm{ft}^{3} / \mathrm{s}$ aquifer discharge from this area (springs and areas of discharge to streams numbered 46 through $86 A$ on pl. 10). By simulating practically all of the base flow from the Suwannee basin, the regional model confirms the predominance of intermediate flow systems and the lack of local flow systems (which the regional model could not simulate even if they occurred), as portrayed in figure $21 B$.

The flow systems in the four-river outcrop area of Georgia and the karstic Suwannee basin of Florida represent "opposite extremes" of ground-water flow patterns occurring in unconfined and semiconfined parts of the aquifer system. Flow patterns in other unconfined and semiconfined areas are some combination of these two extremes but tend to be more like those of the Suwannee basin than the Georgia outcrop area. For example, the karstic, low-lying limestone of the Dougherty Plain in southwest Georgia is drained by the Flint River and (near Lake Seminole) by the Chattahoochee River. The Flint and Chattahoochee Rivers have more of a tributary stream network than the Suwannee but much less of a tributary stream network than the four major rivers draining the Floridan outcrop area farther east in Georgia. Hayes and others (1983, p. 34) estimated the mean annual base flow of streams in the Dougherty Plain to be about $4,000 \mathrm{ft}^{3} / \mathrm{s}$. A thin mantle of residuum contributes an estimated 15 percent of this amount (Maslia and Hayes, in press). Thus, about $3,400 \mathrm{ft}^{3} / \mathrm{s}$ is Floridan aquifer discharge. Simulated aquifer discharge to the Flint and Chattahoochee by both the regional model and by the subregional model (Maslia and Hayes, in press) was about 2,500 ft $3 / \mathrm{s}$. Apparently, some local flow systems involving the Upper Floridan are too small to be simulated, even with the 4-mi by 4-mi grid blocks of the subregional model.

Where unconfined or semiconfined parts of the aquifer system extend offshore (northwest peninsular Florida, east-central Florida, and South Carolina; see pl. 1), the

\footnotetext{
${ }^{1}$ Includes the $2,900 \cdot \mathrm{mi}^{2}$ drainage area above the gaging station on the Suwannee River near Wilcox, Fla. (02323500), and below the following gaging stations: Santa Fe River at White Springs, Fla. (02315500); Alapaha River near Statenville, Ga. (02317500); Withlacoochee River near Pinetta, Fla. (02319000); Santa Fe River at Worthington Springs, Fla. (02321500); Olustee Creek at its mouth, Fla. (02321894).
}

lack of resistance to aquifer discharge allowed predevelopment heads to be near sea level (pl. 4). A consequence of low heads along minimally confined parts of the Gulf and Atlantic coasts is that freshwater flow is shallow and of relatively limited seaward extent. Sprinkle (1982c) noted that the proximity of saline water in the Upper Floridan aquifer to the Gulf coast has been documented by a number of investigators (Trapp, and others, 1977; Mills and Ryder, 1977; Sinclair, 1978; Hickey, 1979; Hickey and Barr, 1979). From the work of Wyrick (1960) and the relation of the altitude of the top of the Upper Floridan aquifer with the low heads that occur near shore, the presence of saline water in the Upper Floridan is inferred to be shallow and relatively close to the Atlantic coast in east-central Florida. In South Carolina, Counts and Donsky (1963), McCollum and Counts (1964), and Hayes (1979) have documented the presence of saline water in the lower part of the Upper Floridan aquifer.

\section{CONFINED AREAS}

Predevelopment ground-water flow in parts of the aquifer system that are deeply buried and confined, primarily southeast Georgia and northeast Florida, south Florida, and far-west panhandle Florida (pl. 1), was (and is) very sluggish compared to flow in unconfined and semiconfined areas. Floridan discharge to springs, streams, and lakes is practically nonexistent; discharge occurs almost exclusively by diffuse upward leakage through thick overburden. As would be expected, rates of recharge and discharge in confined areas in general are considerably lower than rates in unconfined and semiconfined areas (pl. 11). Transmissivity (pl. 2) is also generally lower in deeply buried and confined areas, but the association of low transmissivity with these areas is less than the association of low recharge/discharge with deeply buried and confined parts of the system.

Relatively high transmissivity $(250,000-1,000,000$ $\mathrm{ft}^{2} / \mathrm{d}$ ) in some confined areas (for example, southeast Georgia west and northwest of Brunswick, and south Florida west-northwest of Lake Okeechobee) is probably due to karst development during Oligocene or early Miocene time. Freshwater occupied more of the aquifer system then; recharge probably occurred through sinkholes that are now buried by Miocene and younger deposits and are below present sea level; freshwater discharge probably occurred farther offshore. More active circulation during Oligocene-Miocene time resulted in more aggressive solution of the limestone then than now, thus creating the major part of the permeability that exists today. 
The idealized pattern of flow from the Floridan outcrops in Georgia to the Atlantic coast (fig. 21A) suggests that most of the flow occurs within the outcrop area. Only a very small part of the Floridan recharge moves downgradient and becomes intermediate and regional flow in the confined area. Plate 11 shows that recharge entering the Upper Floridan in the confined area is less than $1 \mathrm{in} . / \mathrm{yr}$. Thus, the amount of water that reached the predevelopment discharge area along the coast and offshore of southeast Georgia and northeast Florida was relatively small. This small amount of water discharged over the large discharge area resulted in a very low rate of diffuse upward leakage.

As mentioned in the section on transmissivity, a band of low transmissivity occurs across south-central Georgia downdip of the outcrop area that is coincident with a northeast-trending band of closely spaced contours on the predevelopment potentiometric surface (pl. 4). The low transmissivities associated with the Gulf Trough probably account for the very low flow rate from the outcrop area downdip to coastal discharge areas. Miller (1986) attributed the low transmissivity to a series of northeast-trending grabens and suggested that the juxtaposition of low-permeability clastic sediments and high-premeability Floridan limestone along the grabens has created a damming effect on the generally southeastward-flowing ground water.

The predevelopment freshwater flow system extends farther offshore in the southeast Georgia-northeast Florida area than in any other part of the aquifer system. The highest predevelopment heads along the southeast Georgia-northeast Florida shoreline (about $70 \mathrm{ft}$ above sea level) occur where the Upper Floridan is most deeply buried. The tight confinement associated with the thick overburden maintained high heads prior to ground-water development, thus establishing an equilibrium position of the freshwater-saltwater interface that is deep and far offshore.

The assumption that a freshwater-saltwater interface exists and defines the seaward extent of the flow system is supported in one location by head and salinity data obtained during recent hydrologic testing in an offshore oil well (Tenneco Oil Company) 55 mi east of Fernandina Beach, Fla. (Johnston and others, 1982). These data in conjunction with data obtained from a previous offshore drilling program (Wait and Leve, 1967) suggest the existence of an interface. At the Tenneco site, the position of the interface (about 1,100 ft below sea level) is nearly compatible with both the estimated predevelopment head and the present head, since they are similar (estimated to be $30 \mathrm{ft}$ and $27 \mathrm{ft}$, respectively).

The aquifer system is also deeply buried and confined in south Florida. The regional flow model confirmed the prior assumption that the flow system is extremely sluggish there. Plate 11 shows that the area of south Florida over which discharge occurs is large compared to the area over which recharge occurs. The only area of substantial predevelopment recharge for the whole of south Florida is the elongate ridge area of northwest Highlands and south-central Polk Counties; and, as the predevelopment potentiometric surface implies, most of the recharge occurring in the Highlands County-Polk County ridge areas moves laterally toward discharge areas along the Gulf and Atlantic coasts rather than southward. Thus, the amount of water in the aquifer flowing to south Florida, particularly south of Lake Okeechobee, is small relative to that flowing to the east and west coasts. A small amount of water discharged over the large area of upward gradient adjacent to and south of Lake Okeechobee results in the very low predevelopment discharge rate of less than $0.1 \mathrm{in} . / \mathrm{yr}$.

The Upper Floridan aquifer south of about Lake Okeechobee, and along both coasts of the southern half of the peninsula contains slightly saline water but is considered part of the freshwater flow system. However, the Lower Floridan aquifer south of Lake Okeechobee (including the Boulder Zone) is too salty to be considered a part of the freshwater flow system.

Because of a lack of nearshore chloride-with-depth data, offshore head data, and top-of-aquifer data, the seaward boundary of the freshwater flow system along the Atlantic coast from mid-Brevard County southward to mid-Martin County (pl. 11) is conjectural. The same is true along the Gulf coast from Lee County southward to the Florida Keys. From the Keys northward along the Atlantic coast to Martin County, the seaward limit of freshwater flow is defined by the Florida-Hatteras Slope (Uchupi, 1966), a steep submarine incline very close to the shoreline. As the slope flattens onto the Miami Terrace at an ocean depth of about $1,000 \mathrm{ft}$, outcropping limestone of the Upper Floridan aquifer just offshore from Miami provides for potential submarine ground-water discharge (F. W. Meyer, U.S. Geological Survey, written commun., 1982). The predevelopment flow model simulated less than $5 \mathrm{ft}^{3} / \mathrm{s}$ of lateral discharge along the southeast Florida boundary. Discharge along the slope should be minimal because of the small amount of ground-water flow to south Florida.

The third deeply buried, confined part of the aquifer system is far-west panhandle Florida. From its outcrop in southern Alabama, the seaward dip on the limestone is steeper than in any other part of the aquifer system. The predevelopment flow system is similar to that of southeast Georgia (fig. 21A), except that the Floridan is much less transmissive (pl. 2) and flow paths are shorter toward the coast. The major part of recharge in the Alabama outcrop area probably enters local flow systems and discharges to streams in the outcrop area. 
A small amount of the outcrop recharge, together with a small amount of recharge that occurs immediately downdip of the outcrop, becomes intermediate and regional flow that eventually discharges near the coast or offshore. As in southeast Georgia and south Florida, the rate of ground-water flow toward the discharge area is very low and upward leakage in coastal areas is minimal (pl. 11).

Water in the Upper Floridan becomes saline near the northern part of Pensacola Bay, and its quality presumably deteriorates rapidly as the aquifer dips steeply in a southwesterly direction (Sprinkle, 1982c, 1982d). This accounts for the offshore boundary of the flow system turning back onshore toward the north-south trending fault zone that forms the western boundary of the aquifer system.

The degree of confinement ultimately controls ground-water flow in the Floridan aquifer system. Tight confinement limits diffuse upward leakage thereby restricting intermediate and regional flow and restricting recharge. The occurrence of high transmissivity in tightly confined parts of the system does not enhance intermediate and regional ground-water flow. In contrast, high transmissivity plus the ease of ground-water discharge to springs and streams in the unconfined and semiconfined areas allows for vigorous shallow intermediate ground-water flow and high rates of recharge.

\section{AREAL AND VERTICAL DISTRIBUTION OF FLOW}

The areal distribution of predevelopment discharge, based on simulation, is shown in figure 22. To contrast the large areal variation in discharge, the aquifer has been divided into eight major ground-water basins based on the predevelopment potentiometric surface (pl. 4). Ground-water discharge rates for the basins are given to the nearest $5 \mathrm{ft}^{3} / \mathrm{s}$ and are proportional to the area of circles in figure 22 .

Regionally and in every basin except south Florida, the predominance of spring discharge and aquifer discharge to surface-water bodies over diffuse upward leakage is apparent. Not surprisingly, the five basins where unconfined, or semiconfined conditions predominate (Dougherty Plain-Apalachicola, Thomasville-Tallahassee, Suwannee, west-central Florida, and east-central Florida), although comprising only about 50 percent of the Floridan's area of occurrence, contribute 88 percent of the total predevelopment discharge of $21,555 \mathrm{ft}^{3} / \mathrm{s}$.

In the panhandle basin, diffuse upward leakage occurs over the major part of the area. Confinement is lacking in the eastern third of the basin and along the outcrop, allowing direct aquifer discharge to streams. Simulated predevelopment aquifer discharge to the Choctawhatchee River, Holmes Creek, and Econfina Creek (pl. 10) is more than seven times greater than the diffuse upward leakage that occurs over a much larger part of the basin area. Similarly, in the southeast Georgianortheast Florida-south South Carolina basin, about three-quarters of simulated predevelopment discharge goes to the four major rivers crossing the areally small northern outcrop. Diffuse upward leakage occurs over a much larger area but accounts for a minor part of the basin discharge. Only in south Florida, where no unconfined or semiconfined areas exist, is diffuse upward leakage the major form of predevelopment discharge. The $100 \mathrm{ft}^{3} / \mathrm{s}$ of simulated predevelopment discharge from south Florida represents less than 1 percent of the total Floridan discharge.

The simulated predevelopment discharge in south Florida intuitively seems low. The predevelopment potentiometric surface simulated (pl. 4) in peninsular Florida is based largely on Stringfield's (1936) potentiometric surface map depicting heads measured in 1934. Possibly, the 1934 heads in the Hardee-HighlandsDeSoto Counties area are lower than the actual predevelopment heads there due to agricultural groundwater development prior to 1934 (F. W. Meyer, U.S. Geological Survey, oral commun., 1983). Higher predevelopment heads in the Hardee-Highlands-DeSoto Counties area would mean a larger gradient from that area toward south Florida and, therefore, potentially more flow. However, predevelopment ground-water flow to south Florida would still have been very low because tight confinement severely restricts upward leakage.

In the Dougherty Plain-Apalachicola basin, major streams (Flint and Chattahoochee Rivers in Georgia, Apalachicola and Chipola Rivers in Florida) and several large springs in Jackson County, Fla. (pl. 10), control the flow system. Diffuse upward leakage is the smallest fraction of total predevelopment discharge of any of the basins because the basin's coastal area of upward gradient is the smallest among the basins.

The predevelopment flow system in the TallahasseeThomasville basin is dominated by large springs near the coast. About $3,500 \mathrm{ft}^{3} / \mathrm{s}$ flows from 11 known springs, nearly half of which is contributed by Spring Creek Springs. The Spring Creek Springs group, consisting of at least eight submarine orifices in proximity, collectively form the largest known spring of the Floridan aquifer system (no. 34, pl. 10 and table 4). Most of the recharge to sustain this high discharge occurs in the virtually unconfined, highly transmissive area just to the north around Tallahassee, Fla., and extending northeast to about Thomasville, Ga.

The Suwannee basin is the most active part of the aquifer system in terms of ground-water flow. More than one-fourth of the total predevelopment discharge, or about $6,000 \mathrm{ft}^{3} / \mathrm{s}$, occurred in this basin. The large 


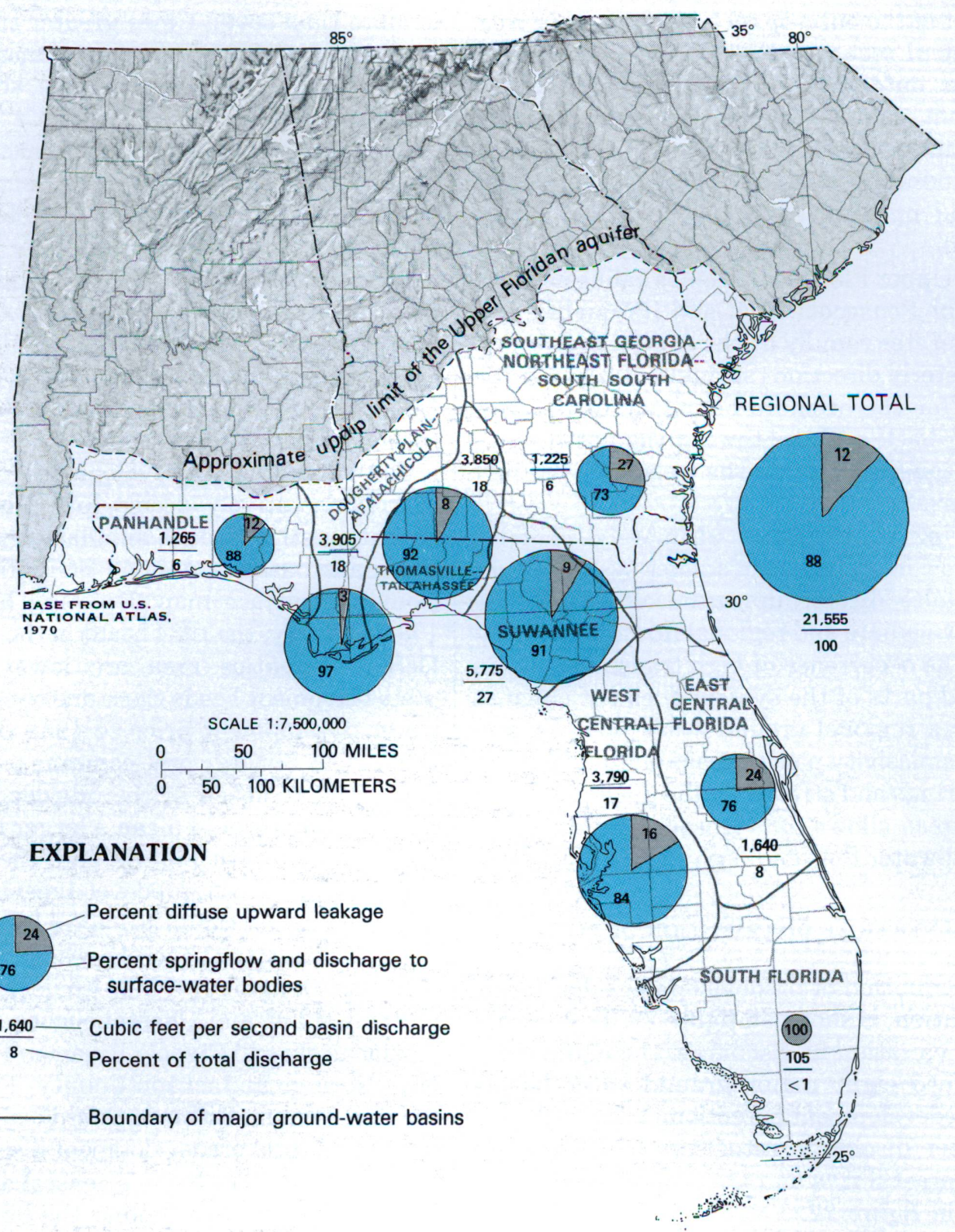

FIGURE 22.-Estimated predevelopment discharge from major ground-water basins of the Upper Floridan aquifer.

concentration of springs along the Withlacoochee, Suwannee, and Santa Fe Rivers, and additional points of direct aquifer discharge to these streams (pl. 10) accounts for most of the discharge. Rates of diffuse upward leakage range from $5-10 \mathrm{in}$./yr along the coast of the Suwannee basin; higher than anywhere else in the aquifer system. However, the simulated high rate of upward leakage probably includes unidentified point discharges such as submarine springs.

The west-central Florida basin consists of two contrasting predevelopment flow systems: In the northern two-thirds of the basin, the aquifer system is unconfined or semiconfined. High recharge and vigorous shallow intermediate flow to springs, most of which are concentrated near the coast (pl. 10), characterize the area. In the southern third of the basin, the aquifer system is confined, and consequently the flow system becomes progressively more sluggish as confinement increases with distance to the south. Most of the approximately $4,000 \mathrm{ft}^{3} / \mathrm{s}$ predevelopment basin discharge (fig. 22) occurred in the northern part of the basin.

The aquifer system in the east-central Florida basin 
consists of unconfined or semiconfined conditions in the northern three-quarters and confined conditions in the southern quarter. The most prominent feature of the predevelopment flow system in east-central Florida is the concentration of springs generally along the St. Johns River valley (pl. 10). These springs, together with aquifer discharge to streams and lakes, contribute about three-fourths of the roughly $1,700 \mathrm{ft}^{3} / \mathrm{s}$ predevelopment basin discharge. Diffuse upward leakage is a greater fraction of the discharge in the east-central Florida basin than in the four other basins in which the aquifer system is predominantly unconfined or semiconfined primarily because the area over which upward leakage occurs is highest among the five basins.

The vertical components of predevelopment flow among layers of the Floridan aquifer system, as derived from simulation, are summarized in figure 23. As in figure 22, components of flow in figure 23 are shown to the nearest $5 \mathrm{ft}^{3} / \mathrm{s}$. This is not to imply the level of accuracy but to present a balanced water budget. Once again, this illustration conveys the fact that the flow system of the Floridan, prior to ground-water

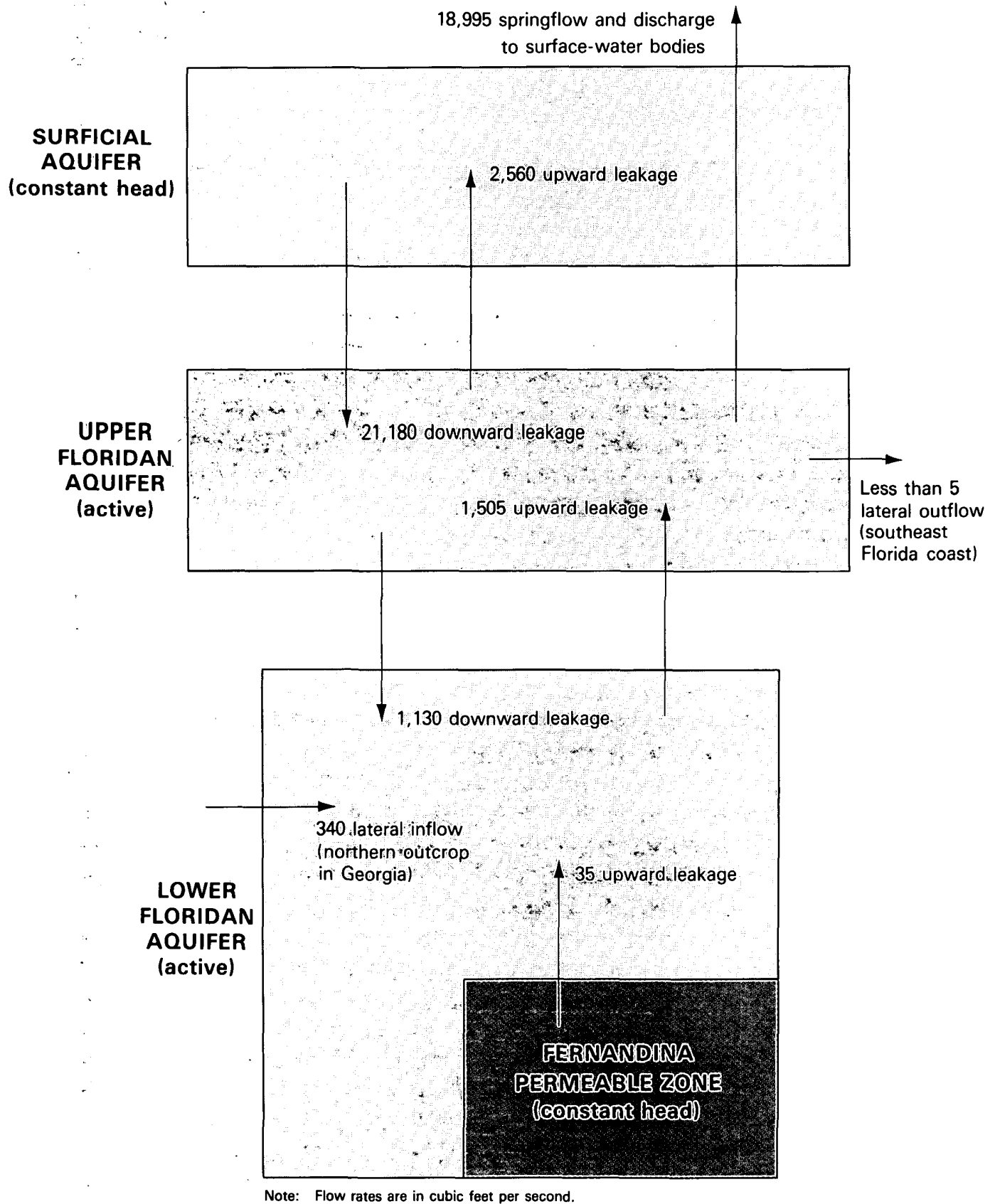

FIGURE 23.-Simulated predevelopment components of flow among units associated with the Floridan aquifer system. 
development, is primarily a shallow flow system. Simulation shows predevelopment ground-water flow in the Upper Floridan to be about 15 times greater than that in the Lower Floridan. Without pumping in the system, the Fernandina permeable zone is nearly dormant. Ninety-eight percent of the simulated predevelopment recharge to the aquifer system occurs as downward leakage from the surficial aquifer (including direct recharge to the Upper Floridan where the surficial aquifer is missing). Simulated predevelopment discharge from springs together with discharge to streams and lakes is more than seven times greater than discharge as diffuse upward leakage.

\section{THE CURRENT FLOW SYSTEM}

The current flow system can best be summarized by the 1980 potentiometric-surface map of the Upper Floridan aquifer. This map (pl. 5) is the first aquiferwide potentiometric map based on nearly simultaneous head measurements. More than 2,700 water-level and pressure-head measurements made during May 1980 in wells tapping the Upper Floridan aquifer were used to construct the map. Plate 5 has been modified from the original published version (Johnston and others, 1981) as described in Appendix A.

Comparison of the 1980 potentiometric-surface map with the predevelopment potentiometric-surface map (pl. 4) shows that the major features of the flow system remain unchanged by ground-water development. Ground water still flows generally from topographically high outcrop and inland areas toward the Gulf and Atlantic coasts. Stream-aquifer interaction still controls the configuration of the potentiometric surface, and hence the flow system, along the northern outcrop and in the Dougherty Plain in Georgia. Spring discharge and aquifer discharge to streams is still apparent in the configuration of the potentiometric surface in unconfined and semiconfined areas (for example, in the Suwannee River and St. Johns River basins). Discharge from Upper Floridan aquifer springs continues to be the dominant feature of the regional flow system; and the degree of confinement on the Upper Floridan is still the major hydrogeologic control on the distribution of recharge, discharge, and ground-water flow.

Similarity of the current flow system to the predevelopment flow system does not mean that ground-water development has not brought significant change. In 1980 , about $3 \mathrm{Bgal} / \mathrm{d}$ were pumped from the aquifer system for all uses, an amount equal to about 20 percent of estimated predevelopment recharge and discharge. This pumpage has resulted in long-term regional declines in head of more than $10 \mathrm{ft}$ in three broad areas of the flow system-coastal Georgia, adjacent South Carolina, and northeast Florida; west-central Florida; and panhandle Florida. The effect of groundwater development on the potentiometric surface is particularly evident at Savannah and Brunswick, Ga., and Fernandina Beach and Fort Walton Beach, Fla., where deep cones of depression have formed (pl. 5). Saltwater encroachment as a result of pumping has occurred in some coastal areas, but its documented extent has been local.

Pumpage has been and continues to be supplied primarily by the diversion of natural outflow from the system and by induced recharge rather than by removing water from aquifer storage. As implied in the section on storage coefficient, the aquifer system's transient response to changes in withdrawal rates dissipates fairly rapidly (days or weeks) in most areas. Thus, on the average (that is, excluding the effects of seasonal changes in stresses) the aquifer system is considered to be approximately at equilibrium, except during periods following sustained increases in pumping.

\section{GROUND-WATER DEVELOPMENT}

Ground-water development began in the late 1800's. The city of Savannah was one of the first major users of water from the Floridan. Before 1887, the city's water supply was taken from the Savannah River, but in that year 14 wells were put into use. No pumping was necessary at that time because the head was about $40 \mathrm{ft}$ above sea level. During 1888 , the rate of withdrawal approached $6 \mathrm{Mgal} / \mathrm{d}$ (Slichter, 1902, p. 97). Counts and Donsky (1963, fig. 3) showed that municipal withdrawals in the Savannah area from 1889 through 1901 remained at 6-6.5 Mgal/d. From 1902 to 1950 , municipal use of water from the Upper Floridan doubled to about $13 \mathrm{Mgal} / \mathrm{d}$. Since 1950, ground water for public supply has been supplemented by surface water from the Savannah River. By the late 1950's, average annual use of Upper Floridan water for public supply had risen as high as $20 \mathrm{Mgal} / \mathrm{d}$.

Starting about 1935, industrial use of Upper Floridan water in the Savannah area, primarily for pulp and paper processing, rose sharply. Counts and Donsky (fig. 3) showed that total ground-water pumpage increased from about $20 \mathrm{Mgal} / \mathrm{d}$ in 1936 to about $42 \mathrm{Mgal} / \mathrm{d}$ in 1943 , the bulk of the increase due to industrial pumpage. Total pumpage again surged upward as a result of industrial demand from about $40 \mathrm{Mgal} / \mathrm{d}$ in 1950 to about $60 \mathrm{Mgal} / \mathrm{d}$ in the late 1950's.

Word about the successful completion of "artesian" wells at Savannah in the 1880's spread to other parts of south Georgia. In one of the earliest reports on ground water in Georgia, McCallie $(1898$, p. 64) stated, 
"The total number of deep wells now in use in south Georgia is between two and three hundred, which number is being increased annually by the completion of from 5 to 20 wells." By 1943, Warren (1944, p. 80) estimated that about 3,500 artesian wells had been drilled in the six counties of coastal Georgia.

In the early 1940's, Upper Floridan discharge to wells in the Brunswick area of Glynn County was nearly as great as that in the Savannah area. About $37 \mathrm{Mgal} / \mathrm{d}$ were withdrawn in the summer of 1943, more than 80 percent of which was used by two large industrial plants (Warren, 1944, p. 24). By 1960, Upper Floridan aquifer withdrawals in Glynn County totaled nearly $100 \mathrm{Mgal} / \mathrm{d}$, with industrial use continuing to account for about 80 percent of that amount (Wait and Gregg, 1973, p. 9).

Industrial demand since the 1940's, primarily for paper and chemicals, has vastly outstripped the demand for all other uses in southeast Georgia. Wait and Gregg $(1973$, p. 9) reported that in the mid-1960's about 90 percent of the estimated $280 \mathrm{Mgal} / \mathrm{d}$ combined average annual pumping at Savannah, Brunswick, Jesup, and St. Marys was for industrial purposes.

The city of Jacksonville was probably the first community to obtain freshwater from wells in the Floridan aquifer system, beginning in 1884 when two wells were drilled (Leve and Goolsby, 1969, p. 15). By the early part of this century, development of the Upper Floridan in Florida was well under way. Matson and Sanford (1913, p. 233), in their comprehensive report on the ground waters of Florida, stated "large numbers of wells have been sunk to the artesian water beds ... along the east coast, from Fernandina southward, in the St. Johns Valley, and along the west coast from Tampa to Fort Meyers." In addition, Matson and Sanford provided summary descriptions of public and private water supplies in central and northern Florida as they existed, presumably, about 1910-12: Two "deep" wells (731-733 ft) supplied the city of Fernandina with $0.6 \mathrm{Mgal} / \mathrm{d}$. At Jacksonville, a "large number" of wells had been drilled to the limestone at depths in the 500-1,000-ft range, primarily to supply railroads, ice factories, and public water systems. The city of Jacksonville by then had 11 wells between 650 and $1,020 \mathrm{ft}$ deep; however, withdrawal rates are unknown. About $0.9 \mathrm{Mgal} / \mathrm{d}$ flowed from two public supply wells $525 \mathrm{ft}$ deep at St. Augustine.

Farther down the east coast in Volusia County, a number of coastal communities including Daytona Beach had numerous private wells generally ranging in depth from 120-300 ft, but no public supplies were documented. Deland was then the largest city in the county. Two wells, 490 and $264 \mathrm{ft}$ deep, supplied that city with about $0.75 \mathrm{Mgal} / \mathrm{d}$.

The largest concentration of Upper Floridan wells inland in central Florida during the 1910-12 period was at Ocala. The public supply consisted of two wells $190 \mathrm{ft}$ deep that filled a demand of about $0.5 \mathrm{Mgal} / \mathrm{d}$. Between 1902 and 1906, the city of Tampa constructed 11 wells ranging from 193-328 ft deep for public water supply. Reported withdrawal rate from 9 of the 11 wells at the time of the Matson and Sanford report was $2.75 \mathrm{Mgal} / \mathrm{d}$. At St. Petersburg, the public supply was obtained from a 432-ft-deep well and a lake. A large number of "artesian" wells are reported among the towns and villages of the coastal corrider between St. Petersburg and Fort Meyers, although reported depths place most of them in the intermediate aquifer (principally Hawthorn) overlying the Upper Floridan. To the north at Tallahassee, a single well $717 \mathrm{ft}$ deep provided the city water supply, with two $400-\mathrm{ft}$ deep auxiliary wells available if needed.

As in coastal Georgia, withdrawal rates in northeast Florida continuously increased over the years to meet the demands of population and industrial growth. Sometimes the increase in ground-water development was dramatic. During the latter part of 1939 , pumpage at Fernandina Beach increased from about $4 \mathrm{Mgal} / \mathrm{d}$ to about $32 \mathrm{Mgal} / \mathrm{d}$ as production of wood pulp and paper began there (Warren, 1944, p. 24). Leve (1961a, fig. 10) showed a steady annual increase in withdrawals at Fernandina Beach over the next $20 \mathrm{yr}$ to about $50 \mathrm{Mgal} / \mathrm{d}$ in 1959. Withdrawal for public supply at Jacksonville was about $6.5 \mathrm{Mgal} / \mathrm{d}$ in 1921 and grew to about $27 \mathrm{Mgal} / \mathrm{d}$ by 1950 . The early public supply wells at Jacksonville were open primarily to the Upper Floridan, but records show that by 1932 the depths of city wells $(1,000-1,250 \mathrm{ft})$ had increased well into the Lower Floridan (Collins and others, 1934, p. 52). By the early 1960 's, Leve (1966, p. 38-39) reported that Jacksonville municipal wells, then numbered at 46 and ranging in depth from 1,000-1,500 $\mathrm{ft}$, produced an average of $38 \mathrm{Mgal} / \mathrm{d}$. Privately owned water utilities in the vicinity added another 15-20 Mgal/d. Self-supplied industrial withdrawals in and near Jacksonville (primarily from the Lower Floridan) had also become appreciable by the early 1960's. Pulp and paper processing accounted for the major part of an estimated $70 \mathrm{Mgal} / \mathrm{d}$ industrial ground-water use. Leve $(1966$, p. 39) estimated total Floridan aquifer-system withdrawals in the early 1960's in the vicinity of Jacksonville to be 150-200 Mgal/d and 50-70 Mgal/d from wells at Fernandina Beach.

The city of Orlando was to become the largest single user of Floridan aquifer-system water in east-central Florida. However, prior to 1932 the entire public water supply was still obtained from surface water. Sometime between 1932 and 1942, two Upper Floridan aquifer wells were drilled to replenish one of the surface water sources, Lake Underhill. In late 1942 and early 1943, 
the U.S. Geological Survey measured the combined yield of these two wells to be $4.7 \mathrm{Mgal} / \mathrm{d}$, which represented about 60 percent of all water processed by the Orlando water-treatment plant at that time (Kimrey, 1978 , p. 11).

Since the early 1900's, drainage wells open to the Upper Floridan have been used in central Florida, and particularly in the Orlando area, to drain storm runoff, control lake levels, and (to a minimal extent presently, due to environmental regulations) dispose of industrial wastewater (Tibbals, in press). Kimrey $(1978$, p. 11) surmised that the need to case supply wells through the potentially polluted drainage-well zone and into the Lower Floridan was recognized in the late 1940's; and as a result, extensive use of the Lower Floridan began in the early 1950's when local public water-supply utilities started switching to direct use of groundwater. By 1963 all municipal, domestic, and industrial water supplies (except cooling) and nearly half the agricultural supplies of Orange County were obtained from wells. Average ground-water pumpage (all assumed to be from the Floridan) in Orange County in 1963 was estimated to be about $60 \mathrm{Mgal} / \mathrm{d}$, of which nearly half was accounted for by the municipal supplies of Orlando and Winter Park (Lichtler and others, 1968, p. 139). The wells supplying those cities tap the Lower Floridan, as do most other large, concentrated withdrawals in the area; but the Upper Floridan is used considerably despite the potential for contamination from drainage wells.

Because of increasingly high chloride concentrations in water from its Upper Floridan supply wells, the city of Tampa shifted from ground water to surface water in 1925. At that time the Hillsborough River became the sole source of public supply for the city (Ryder, 1985). By 1952, the Hillsborough River still accounted for 97 percent of the city's municipal supplies (Lohr and Love, 1954, p. 117). About 1960, the city acquired Sulfur Springs to augment its water supply during times of low river flow. Although Tampa's public water supplies were obtained from surface water, fresh ground-water pumpage for all uses (assumed to be all Floridan) in Hillsborough County about 1960 was estimated to be 55-60 Mgal/d (Menke and others, 1961, p. 86).

Like the city of Tampa, the city of St. Petersburg was forced to abandon it original downtown well field because chloride concentrations in the water withdrawn rose to unacceptable levels. In 1932 the city began operating a well field farther from the coast in northwest Hillsborough County (Parker, 1975, p. 16). By 1951, average pumpage from this well field, which served approximately half the population of Pinellas County, was about $12 \mathrm{Mgal} / \mathrm{d}$. The remainder of the county was served by wells within the county. Estimated water consumption in Pinellas County in 1951, excluding
St. Petersburg's Hillsborough County well field, was 13-14 Mgal/d (Heath and Smith, 1954, p. 46).

Historically, the most intensely developed part of the Floridan aquifer system has been an area centered in southwest Polk County, Fla. (Ryder, 1985). Large withdrawals from the Upper Floridan, primarily associated with the mining and processing of phosphate for fertilizers, have occurred for many years. Robertson and others (1978, fig. 3) showed combined pumpage for phosphate production and citrus processing in the area from 1936 to 1975. Pumpage rose from a low of about $20 \mathrm{Mgal} / \mathrm{d}$ in 1936 to about $150 \mathrm{Mgal} / \mathrm{d}$ in 1963 and then surged to a peak of about $280 \mathrm{Mgal} / \mathrm{d}$ in 1966 . Water conservation and recycling have been largely responsible for the leveling off and decline of industrial pumpage since the late 1960's (Ryder, 1985).

In southern Okaloosa County in panhandle Florida, moderate withdrawals of water from the Upper Floridan have occurred over the years. Trapp and others (1977, p. 18) reported that 10-15 flowing wells were completed in the Upper Floridan in the Fort Walton Beach area between 1923 and 1940 and that all the municipal and military water-supply systems in southern Okaloosa County have been constructed since 1940 . They estimated (p. 16) that average pumpage for municipal and military supply grew from about $1.5 \mathrm{Mgal} / \mathrm{d}$ in 1940 to about $11.0 \mathrm{Mgal} / \mathrm{d}$ in 1968 .

Beginning in 1950 and continuing at 5-yr intervals since, the U.S. Geological Survey has compiled surfacewater and ground-water use data for the 50 states, categorized by major use. Estimated freshwater pumpage from the Floridan aquifer system from 1950 to 1980 for each of the four states served by the Floridan is summarized in table 5 . Sources of the pumpage data presented in table 5 and discussed in the text (unless otherwise referenced) are documented in the footnote of table 5. Figures 24 to 27 show the changes in estimated pumpage for all uses, and for major-use categories, from 1950 to 1980 for the region as a whole and for Florida and Georgia. Total pumpage for all uses (fig. 24) has risen from about $630 \mathrm{Mgal} / \mathrm{d}$ in 1950 to about $3,000 \mathrm{Mgal} / \mathrm{d}$ in 1980 , which represents an average annual increase over the 30-year period of about $80 \mathrm{Mgal} / \mathrm{d}$. In the 20-yr period 1950 to 1970 , the rate of increase in Floridan pumpage for all uses rose appreciably faster in Florida than in Georgia. But in the $10 \mathrm{yr}$ from 1970 to 1980 , the average rate of increase was about the same in both states; since 1975, the average rate of increase in Georgia has surpassed that in Florida. Pumpage for all uses in Florida over the $30 \mathrm{yr}$ has averaged about 75 percent of the total; pumpage in Georgia about 25 percent; and pumpage in Alabama and South Carolina combined, about 1 percent.

Estimated pumpage from the Floridan aquifer system for public supply (fig. 25) in $1980(620 \mathrm{Mgal} / \mathrm{d})$ was more 
TABLE 5.-Estimated freshwater pumpage from the Floridan aquifer system, 1950-80 1

[Values in Mgal/d; <, less than]

\begin{tabular}{|c|c|c|c|c|c|}
\hline $\begin{array}{l}\text { Year and } \\
\text { State }\end{array}$ & $\begin{array}{l}\text { Public } \\
\text { supply }\end{array}$ & $\begin{array}{c}\text { Rural } \\
\text { (domestic } \\
\text { and } \\
\text { livestock) }\end{array}$ & Irrigation & $\begin{array}{l}\text { Industrial } \\
\text { self-supplied } \\
\text { and } \\
\text { thermoelectric }\end{array}$ & Total \\
\hline $\begin{array}{l}1980 \\
\text { Florida } \\
\text { Georgia } \\
\text { Alabama } \\
\text { South Carolina }\end{array}$ & $\begin{array}{l}490 \\
120 \\
<1 \\
\quad 5.9 \\
620\end{array}$ & $\begin{array}{l}150 \\
55 \\
<1 \\
\frac{3.5}{210}\end{array}$ & $\begin{array}{c}960 \\
340 \\
8.0 \\
\quad 1.8 \\
1,300\end{array}$ & $\begin{array}{c}570 \\
280 \\
<1 \\
4.5 \\
850\end{array}$ & $\begin{array}{r}2,20 \\
80 \\
<1 \\
1 \\
3,00\end{array}$ \\
\hline $\begin{array}{l}1975 \\
\text { Florida } \\
\text { Georgia } \\
\text { Alabama } \\
\text { South Carolina }\end{array}$ & $\begin{array}{r}400 \\
90 \\
<1 \\
<10 \\
500\end{array}$ & $\begin{array}{r}130 \\
25 \\
<1 \\
<5 \\
160\end{array}$ & $\begin{array}{r}730 \\
22 \\
7.2 \\
<5 \\
760\end{array}$ & $\begin{array}{r}720 \\
380 \\
<1 \\
<5 \\
1,100\end{array}$ & $\begin{array}{r}2,00 \\
52 \\
<1 \\
1 \\
2,50\end{array}$ \\
\hline $\begin{array}{l}1970 \\
\text { Florida } \\
\text { Georgia } \\
\text { Alabama } \\
\text { South Carolina }\end{array}$ & $\begin{array}{r}310 \\
110 \\
<1 \\
<10 \\
430 \\
\end{array}$ & $\begin{array}{r}94 \\
40 \\
<1 \\
<5 \\
140 \\
\end{array}$ & $\begin{array}{c}790 \\
6.0 \\
5.4 \\
<5 \\
800 \\
\end{array}$ & $\begin{array}{r}620 \\
230 \\
<1 \\
<5 \\
850\end{array}$ & $\begin{array}{r}1,800 \\
39 \\
<1 \\
1 \\
2,200 \\
\end{array}$ \\
\hline $\begin{array}{l}1965 \\
\text { Florida } \\
\text { Georgia } \\
\text { Alabama } \\
\text { South Carolina }\end{array}$ & $\begin{array}{r}260 \\
59 \\
<1 \\
<5 \\
330\end{array}$ & $\begin{array}{l}49 \\
32 \\
<1 \\
<5 \\
85\end{array}$ & $\begin{array}{r}650 \\
14 \\
<5 \\
<5 \\
670\end{array}$ & $\begin{array}{r}630 \\
240 \\
<1 \\
<5 \\
870\end{array}$ & $\begin{array}{r}1,600 \\
350 \\
<10 \\
10 \\
2,000\end{array}$ \\
\hline
\end{tabular}

${ }^{1}$ Does not include thermoelectric pumpage, which in 1980 comprised about 3 percent of combined industrial self-supplied and thermoelectric pumpage.

The pumpage figures listed in table 5 are estimates derived from a number of sources. Although nearly all numbers are shown to two significant figures, some are more accurate than others. The following paragraphs summarize the origin of the figures for each state, and provide a subjective estimate of their relative accuracy.

Florido

1980.-Although the Floridan aquifer system is the principal source of ground-water in Florida, several other aquifers supply water in areas where the quality of Floridan wate is not adequate. Pumpage data collected by State and Federal agencies are not routinely categorized by aquifer from which they are obtained. Total ground water (or surface water by county (and use) is the traditional breakdown. However, Healy (1981) has estimated ground-water pumpage, by county, from principal aquifers for public supply and rura domestic use in 1977 . He lists 20 of Florida's 67 counties for which public water supplies are from sources other than the Floridan. The 1980 estimate for public supply shown in table is the 1980 total sta ground-water pumpage for public supply, minus the sum of 1980 ground-water pumpage for public aupply from 19 of Healy's 20 counties from which public supplies are withdrawn from aquifers other than Floridan (Healy's 20 counties include Brevard, which obtains its supply from the Floridan in adjacent Orange County). The 1980 ground-water pumpage data for public supply in Florida were taken from Leach (1983), supplemented in central Florida by data from Duerr and Trommer (1981) and Marella (1982). Healy (1981) lists 30 Florida counties for which rural domestic supplies are from aquifers other than the Floridan. The 1980 Floridan estimate for rural domestic pumpage was obtained by subtracting the sum of 1980 rural domestic pumpage (Leach, 1983) in Healy's 30 non-Floridan rural domestic counties from the 1980 total state rural domestic pumpage (Leach, 1983). The estimate of 1980 livestock pumpage from the Floridan, which is com bined with rural domestic in table 5, was obtained by subtracting the sum of 1980 groundwater livestock pumpage (Leach, 1983) in Healy's 20 non-Floridan public supply countie from the 1980 total State ground-water livestock pumpage (Leach, 1983).

To obtain the 1980 Floridan estimate for irrigation, 1980 ground-water irrigation pumpage from Healy's 20 non-Floridan public supply counties was summed and subtracted from the 1980 total State ground-water irrigation figure (Leach, 1983). However, the Floridan is a partial source of irrigation water in some of the 20 counties for which the Floridan is not a source of public supply. Estimates of Floridan irrigation pumpage, if any, from the 20 counties were added back to arrive at the figure shown in table 5 . Those estimates for south Florida counties were obtained from data provided by F. W. Meyer (U.S. Geological Survey, written commun., 1983). For each remaining county, an estimate of the fraction of that county's irrigation pumpage that is from the Floridan was made based on published reports or discussions with others familiar with the county's water use.

The self-supplied industrial and thermoelectric pumpage estimate in table 5 was derived in the same way as the estimate for irrigation pumpage. That is, 1980 ground-water pumpage for industrial self-supplied and thermoelectric use from Healy's 20 non-Floridan public supply counties was summed and subtracted from the 1980 total state ground-water industrial self-supplied and thermoelectric figure (Leach, 1983). Because the Floridan is a partial source of industrial water supply in some of the 20 non-Floridan public supply counties, estimates of Floridan industrial pumpage, if any, from the 20 counties were added back. 1950-75. - Beginning in 1950 and continuing at 5-yr intervals since, the U.S. Geological Survey has compiled in (MacKichan,1951, 1957; MacKichan and Kammerer, 1961: Muse data for the 50 states 1972, 1977). The frction of hichan and Kammerer, 1961; Murray, 1968; Murray and Reeves 1972,1977 ). The fraction of the 1980 total State ground-water public supply pumpage that ground-water totals for rural, irrigation, industrial self-supplied, and thermoelectric uses

\begin{tabular}{|c|c|c|c|c|c|}
\hline $\begin{array}{l}\text { Year and } \\
\text { State }\end{array}$ & $\begin{array}{l}\text { Public } \\
\text { supply }\end{array}$ & $\begin{array}{c}\text { Rural } \\
\text { (domestic } \\
\text { and } \\
\text { livestock) }\end{array}$ & Irrigation & $\begin{array}{c}\text { Industrial } \\
\text { self-supplied } \\
\text { and } \\
\text { thermoelectric }\end{array}$ & Total \\
\hline $\begin{array}{l}1960 \\
\text { Florida } \\
\text { Georgia } \\
\text { Alabama } \\
\text { South Carolina }\end{array}$ & $\begin{array}{r}200 \\
66 \\
<1 \\
<5 \\
270 \\
\end{array}$ & $\begin{array}{l}52 \\
24 \\
<1 \\
<5 \\
80 \\
\end{array}$ & $\begin{array}{r}160 \\
15 \\
<5 \\
<5 \\
180\end{array}$ & $\begin{array}{r}580 \\
160 \\
<1 \\
<5 \\
740 \\
\end{array}$ & $\begin{array}{r}990 \\
270 \\
<10 \\
10 \\
1,300 \\
\end{array}$ \\
\hline $\begin{array}{l}1955 \\
\text { Florida } \\
\text { Georgia } \\
\text { Alabama } \\
\text { South Carolina }\end{array}$ & $\begin{array}{r}98 \\
51 \\
<1 \\
<5 \\
150\end{array}$ & $\begin{array}{l}14 \\
8.3 \\
<1 \\
<5 \\
30\end{array}$ & $\begin{array}{r}150 \\
11 \\
<5 \\
<5 \\
170\end{array}$ & $\begin{array}{r}430 \\
140 \\
<1 \\
<5 \\
570\end{array}$ & $\begin{array}{r}690 \\
210 \\
<10 \\
10 \\
920\end{array}$ \\
\hline $\begin{array}{l}1950 \\
\text { Florida } \\
\text { Georgia } \\
\text { Alabama } \\
\text { South Carolina }\end{array}$ & $\begin{array}{l}57 \\
27 \\
<1 \\
<5 \\
85\end{array}$ & $\begin{array}{l}23 \\
20 \\
<1 \\
<5 \\
45\end{array}$ & $\begin{array}{c}87 \\
\text { negligible } \\
<5 \\
\text { negligible } \\
\frac{90}{90}\end{array}$ & $\begin{array}{r}240 \\
160 \\
<1 \\
<5 \\
1410\end{array}$ & $\begin{array}{l}410 \\
210 \\
<10 \\
<10 \\
630\end{array}$ \\
\hline
\end{tabular}

were calculated. The 1980 Floridan fraction of total State ground-water pumpage for each of the four use categories was assumed to be the same in each of the $6 \mathrm{yr} 1950-75$ for which State totals in the four use categories are available. The 1980 Floridan fractions were thus
applied to the 1950-75 State totals for each use category to obtain estimates of Floridan pumpage for each of the four categories. The four resulting figures were summed to obtain the State total

Georgic

1980.-The Georgia District Office of the U.S. Geological Survey was able to provide estimated pumpage from the Floridan aquifer system, categorized by use, in each of the 68 Georgia counties that overlie the Floridan (R. R. Pierce, U.S. Geological Survey, written commun., 1984).

1950-75. - Estimates of Floridan pumpage in each of the four use categories were calculated in the same way as for Florida.

Alabama

1980.-The Geological Survey of Alabama provided estimates of Floridan aquifer system pumpage, categorized by use, in Covington, Geneva, and Houston Counties (R. M. Baker, Geological Survey of Alabama, written commun., 1984). We assumed that Floridan pumpage from the other four Alabama counties wholly or partially underlain by the Floridan is negligible because (1) total ground-water pumpage from those counties is very low and (2) other aquifers are commonly tapped by wells.

1950-75. - Estimates of Floridan pumpage in each of the four use categories were calculated in the same way as for Florida. Because the fractions of total Statewide pumpage in each use category that is from the Floridan are small, the Floridan pumpage figures thus calculated are small-and subject to appreciable error (relative to their magnitudes). For this reason the figures listed in table 5 are shown as "less than" a given rate.

South Carolina

1980.-The Floridan pumpage figures shown for the four use categories are the sums of 1980 ground-water pumpage for each of the four use categories, respectively, in Beaufort, Hampton, and Jasper Counties, plus one-third the ground-water pumpage of Allendale County. We assumed that Floridan withdrawals from Colleton and Charleston Counties were negligible (W. R. Aucott, U.S. Geological Survey, oral commun., 1984).

1950-75. - Estimates of Floridan pumpage in each of the four use categories were calculated 1950-75. - Estimates of Floridan pun
in the same way as for Alabama.

in the same way as for Alaba
Evaluation of pumpage data

Among the four principal-use categories, the figures for public supply are the most accurate Public-supply facilities are known, the water is metered, and records are kept. Industria elf-supplied and thermoelectric pumpage is next in accuracy. Most industrial water users monitor their water use or can at least estimate their pumping rates. Rural use is probably the next most accurate figure. Rural pumpage is estimated indirectly by applying per-capita use figures (for both people and livestock) to county populations not served by public supplies. Irrigation pumpage is likely the least well known. Various indirect means are used to estimate irrigation pumpage; for example, monitoring pumping time at selected representative farms or estimating delivery rates for major types of sprinkler systems and then applying those factors, together with optimum crop requirements, to the num
inventoried. But, it is inherently difficult to obtain good irrigation data.

inventoried. But, it is inherently difficult to obtain good irrigation data. Among the four States, the 1980 pumpage figures for Georgia are probably the best. The
Georgia District of the U.S. Geological Survey has made a special effort to provide groundGeorgia District of the U.S. Geological Survey has made a special effort to provide groundwater pumpage data by aquifer; and only a small area along the outcrop is where appreciable lorida pumpage figures are probably the next most accurate. The accuracy is lessened when the fraction of total ground-water pumpage that is from the Floridan must be estimated in areas where water from other aquifers is available. Such areas are more prevalent in Florida than in Georgia, but they represent a small fraction of the total area served by the Floridan in Florida. The Alabama and South Carolina figures for 1980 are probably the least accurate because the several counties included in each of those States overlie the fringes of the Floridan; hus, the probability is higher that

It is reasonable to assume that the accuracy of the later pumpage data in all States is greater than that of the early data. Methods of gathering the data continue to improve, and the time and effort devoted to acquiring data increase each year. 


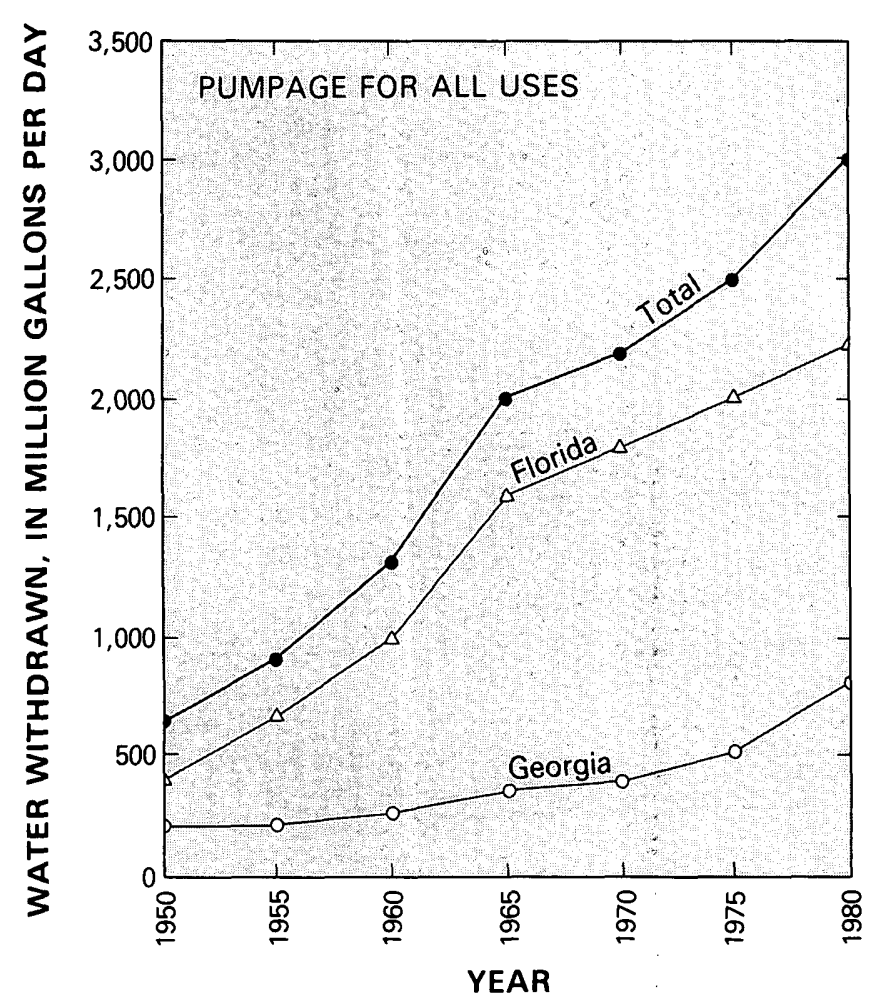

Figure 24.-Estimated Floridan aquifer system pumpage for all uses, $1950-80$.

than seven times the rate in 1950 (85 Mgal/d). Rising demand for public water supplies in Florida was the dominant factor causing this increase. The population served by the Floridan in Florida nearly tripled during the 30 -yr period, whereas the combined population served by the Floridan in Georgia, Alabama, and South Carolina grew by less than one-third (based on county population data from U.S. Department of Commerce, 1981, table 2). Overall, the entire population served by the Floridan in 1980 was about 2.2 times that served in 1950.

Estimated rural pumpage from the Floridan in 1980 $(210 \mathrm{Mgal} / \mathrm{d})$ was close to five times larger than rural pumpage in $1950(45 \mathrm{Mgal} / \mathrm{d})$. Again because of the difference in rates of population growth, the rate of increase in rural pumpage in Florida outpaced that in Georgia.

Public supply pumpage and rural pumpage, taken together over the $30-\mathrm{yr}$ period 1950 to 1980 , increased about 540 percent; yet the population served by that pumpage increased only about 120 percent. Clearly the trend in per capita water use since 1950 is upward. However, during the 10-yr period 1970 to 1980 , the trend is reversed. Public supply and rural pumpage increased about 25 percent during the 10 -yr period, while the population served by that pumpage increased about 40 percent.

Estimated pumpage from the Floridan for irrigation

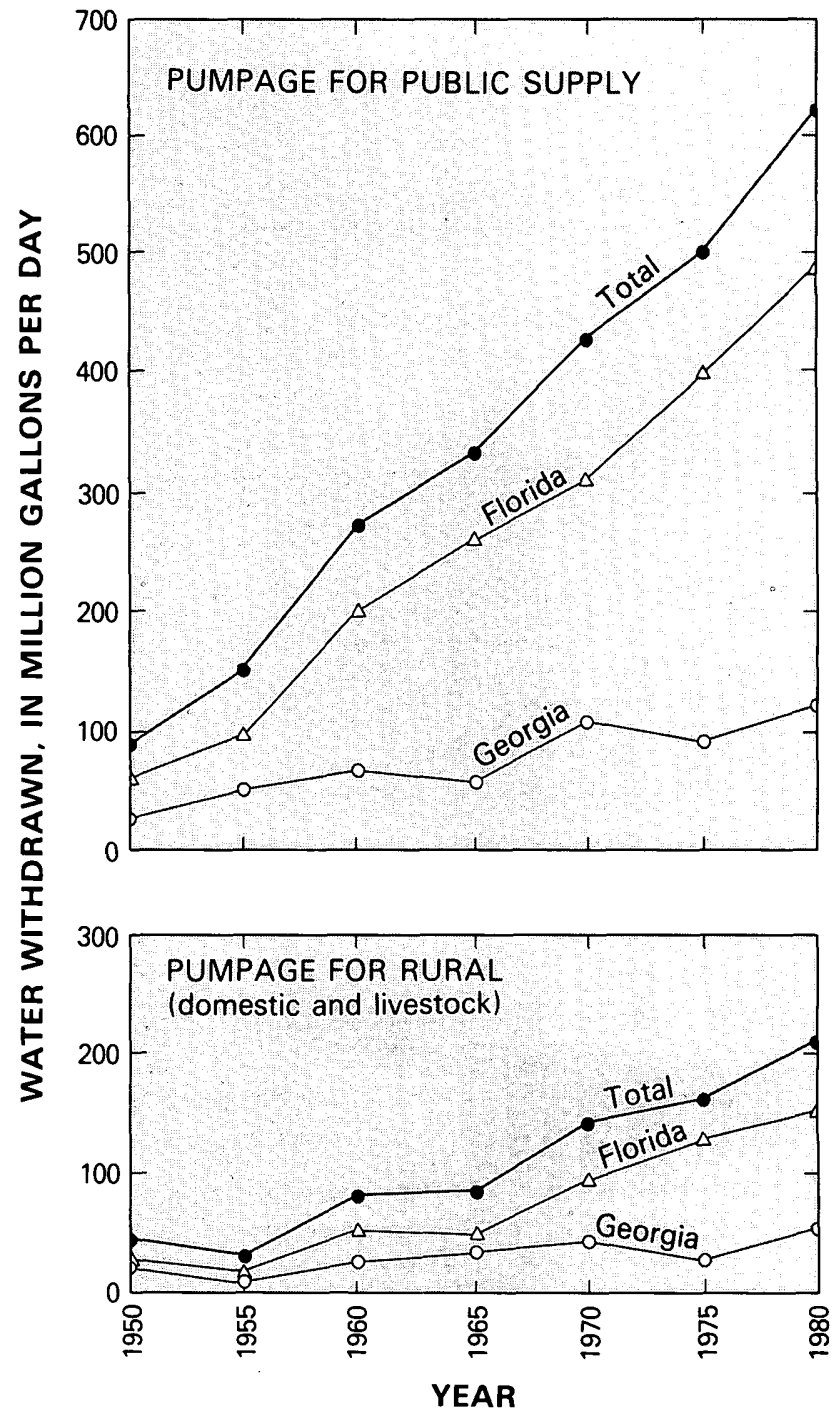

Figure 25.-Estimated Floridan aquifer system pumpage for public supply and rural use, 1950-80.

between 1950 and 1980 (fig. 26) has increased more than for any other major use. The estimate of irrigation pumpage in 1950 was $90 \mathrm{Mgal} / \mathrm{d}$; in 1980 it was 1,300 Mgal/d. Until the mid-1970's, virtually all of the growth in irrigation pumpage occurred in Florida. Total acreage irrigated by water from all sources in the state tripled between 1960 and 1980, and during the same period the amount of water applied per acre has increased about 50 percent (Spechler, 1983). In some parts of central Florida, however, increasing demand for well-drained land for housing has resulted in a reduction in acreage for citrus, the state's major crop. Robertson and others (1978, fig. 4) show a decline in citrus acreage over time in southwest Polk County beginning in the late 1960's, after a steady increase since the 1930's.

The most striking trend in irrigation pumpage shown in figure 26 is the soaring increase that has occurred 


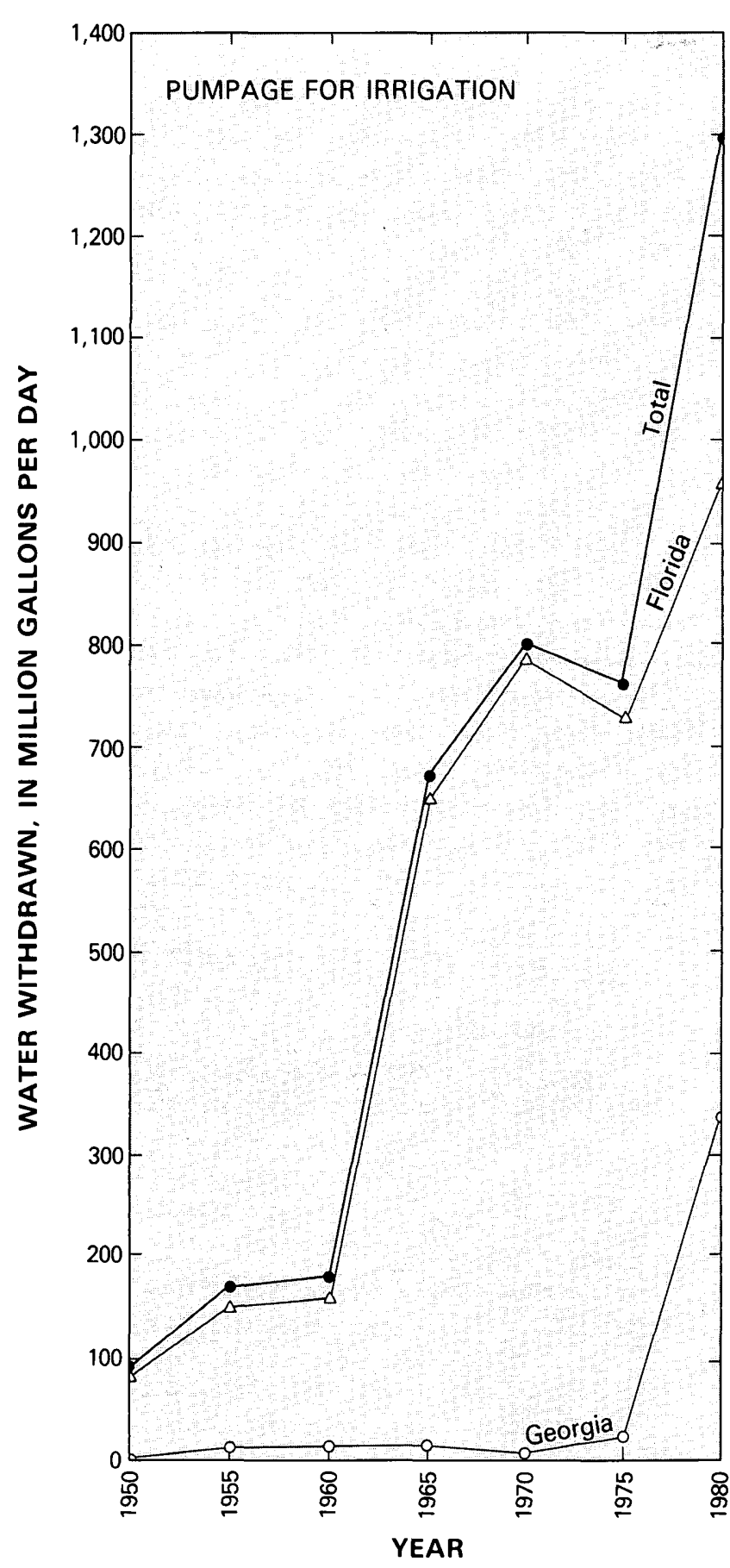

Figure 26.-Estimated Floridan aquifer system pumpage for irrigation, 1950-80.

in Georgia since the mid-1970's. Much of this increase is due to the rapid growth of irrigation systems in the 15-county Dougherty Plain area of southwest Georgia. Irrigation pumpage in this area was only about $3 \mathrm{Mgal} / \mathrm{d}$ in 1970 (Carter and Johnson, 1974, table 1). By 1977 it had grown to about $130 \mathrm{Mgal} / \mathrm{d}$, and by 1980 it was about $210 \mathrm{Mgal} / \mathrm{d}$ (Maslia and Hayes, in press).

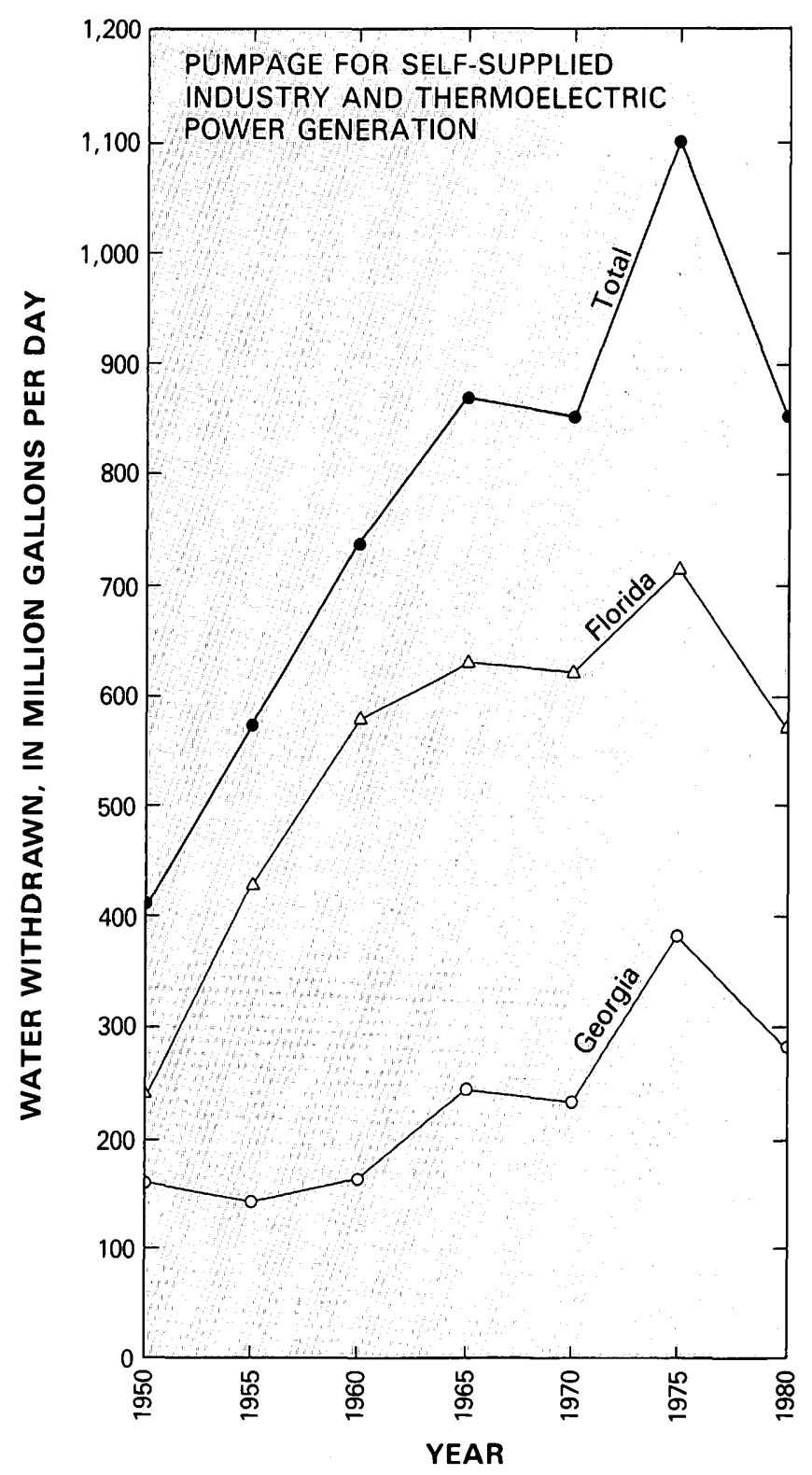

FIGURE 27.-Estimated Floridan aquifer system pumpage for selfsupplied industry and thermoelectric power generation, 1950-80.

Estimated pumpage for self-supplied industry and thermoelectric power generation from the Floridan (fig. 27) rose sharply from about $410 \mathrm{Mgal} / \mathrm{d}$ in 1950 to $870 \mathrm{Mgal} / \mathrm{d}$ in 1965 , then declined in the late-1960's, rose to an all-time high of $1,100 \mathrm{Mgal} / \mathrm{d}$ in the mid-1970's, and then by 1980 dropped back to its 1970 rate of $850 \mathrm{Mgal} / \mathrm{d}$. The trend in Florida paralleled the regional trend during the 30 -year period. Changes in pumpage are assumed to be related in part to economic conditions, but the most recent downward trend $(1975-80)$ is probably due to more efficient use of water through conservation and recycling. Six of Florida's seven 
major water-using industries (limestone mining, pulp and paper processing, phosphate mining, citrus processing, food processing, and air conditioning) showed declines in use of water from all sources between 1975 and 1980. Only one industry, chemical products, showed an increase (Leach, 1983, p. 27).

From 1965 to 1980, the Floridan industrial water-use trend in Georgia was similar to that in Florida. Average combined industrial pumpage for pulp and paper processing and chemical production in the four areas of longtime industrial water use-Savannah, Brunswick, Jesup, and St. Marys-has been about $250 \mathrm{Mgal} / \mathrm{d}$ since the mid-1960's (Wait and Gregg, 1973, p. 9; Carter and Johnson, 1974, table 1; Pierce and others, 1982, p. 34, $39,77,165)$.

The percentage of pumpage from the Floridan aquifer system for each of the four major-use categories has changed since 1950. Figure 28 shows that combined pumpage for public supply and rural use was slightly less than one-quarter of total pumpage in 1950 and slightly more than one-quarter in 1980 . The small decrease in percentage of rural use together with the increase in percentage of public supply reflect census statistics that show more rapid urban rather than rural population growth during the 30 years 1950 to 1980 (U.S. Department of Commerce, 1961, 1981). Also, individual municipal water systems have expanded to include areas within cities and towns that were formerly supplied by private wells.

Between 1950 and 1980, a major shift occurred in water use from industrial and thermoelectric to irrigation. The percentage of total pumpage for irrigation more than tripled, from 13 percent in 1950 to 44 percent in 1980. The percentage for industrial and thermoelectric use during the same period dropped by more than one-half, from about 65 percent to 28 percent. Sometime between 1975 and 1980 , the rate of irrigation pumpage surpassed that for industrial and thermoelectric use (table 5). In 1980 Floridan pumpage for thermoelectric power generation comprised about 3 percent of combined industrial and thermoelectric pumpage.

The regional distribution of estimated pumpage from the Floridan aquifer system by county in 1980 for all uses and for major-use categories (except rural) are
1950

630 MILLION GALLONS PER DAY

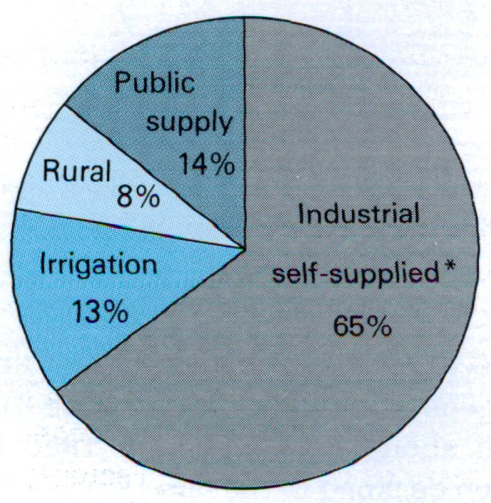

* Does not include thermoelectric pumpage, which in 1980 comprised about 3 percent of combined industrial self-supplied and thermoelectric pumpage.
1980

3,000 MILLION GALLONS PER DAY

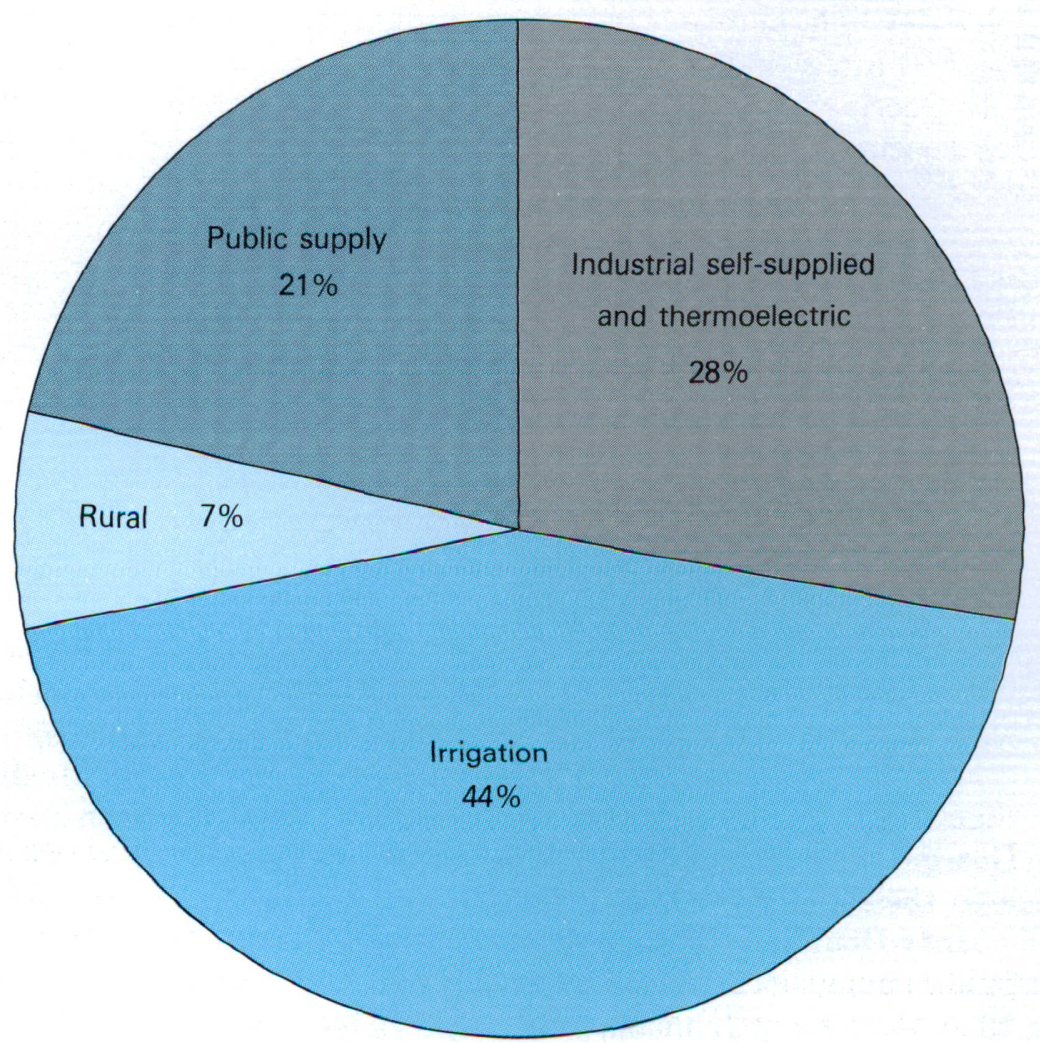

FIGURE 28.-Percentage of Floridan aquifer-system pumpage by category, 1950 and 1980. 
shown on plates 12 to 15 . Heaviest withdrawals occur in central Florida. Pumpage in the five-county area composed of Pinellas, Hillsborough, Pasco, Polk, and Orange Counties was about $820 \mathrm{Mgal} / \mathrm{d}$ in 1980 , or about 27 percent of the total $3,000-\mathrm{Mgal} / \mathrm{d}$ Floridan pumpage. Plate 12 shows that Polk County was the mostly heavily pumped individual county with 1980 Floridan pumpage of about $310 \mathrm{Mgal} / \mathrm{d}$. Orange County (encompassing the Orlando-Winter Park area) was second in 1980 total pumpage, withdrawing an estimated $200 \mathrm{Mgal} / \mathrm{d}$. About 30 percent of this pumpage was from the Lower Floridan in the Orlando-Winter Park area. Floridan pumpage in Hillsborough, Pasco, and Pinellas Counties (the Tampa-St. PetersburgClearwater area) was about 160,100 , and $50 \mathrm{Mgal} / \mathrm{d}$, respectively, in 1980 .

In northeast Florida, Duval County (Jacksonville area) and adjacent Nassau County (Fernandina Beach area) accounted for about 110 and $50 \mathrm{Mgal} / \mathrm{d}$, respectively, of the pumpage from the Floridan in 1980. About 45 percent of Duval County's pumpage was from the Lower Floridan in the Jacksonville area.

Pumpage in Okaloosa County (Fort Walton Beach area) in the Florida panhandle during 1980 was light compared to Floridan pumpage in central and northeast Florida. Withdrawals in the entire county averaged only about $18 \mathrm{Mgal} / \mathrm{d}$; but, as explained in the next section, relatively light pumpage in the Fort Walton Beach area has had a regional impact on water levels.

In Georgia, largest withdrawals from the Floridan in 1980 occurred in Glynn County, which includes Brunswick. Estimated total pumpage was about $100 \mathrm{Mgal} / \mathrm{d}$. Pumpage in 1980 in Chatham County (Savannah) and Wayne County (Jesup) was moderately heavy, about $75 \mathrm{Mgal} / \mathrm{d}$ in each county.

Total Floridan pumpage for public supply in 1980 was about $620 \mathrm{Mgal} / \mathrm{d}$. Plate 13 shows that largest 1980 Floridan withdrawals for public supply occurred in Orange County, Fla. Estimated pumpage was 87 $\mathrm{Mgal} / \mathrm{d}$, which includes $18 \mathrm{Mgal} / \mathrm{d}$ withdrawn for use in Brevard County. However, the county using the most water for public supply in 1980 was Pinellas with estimated pumpage of $103 \mathrm{Mgal} / \mathrm{d}$, of which $23 \mathrm{Mgal} / \mathrm{d}$ were imported from Hillsborough County and $43 \mathrm{Mgal} / \mathrm{d}$ were imported from Pasco County.

Following Orange and Pinellas Counties, the 1980 pumpage for public supply in Florida was highest in Duval County $(60 \mathrm{Mgal} / \mathrm{d})$, serving the populous urban area around Jacksonville.

In Georgia, the highest 1980 Floridan withdrawals for public supply occurred in Chatham County $(29 \mathrm{Mgal} / \mathrm{d})$, most of which were for the city of Savannah. Like the city of Tampa, however, the major part of Savannah's 1980 public supply was furnished by surface water.
Irrigation pumpage from the Floridan in 1980 (pl. 14), the most difficult among the major-use categories to quantify (see footnote, table 5), was about $1,300 \mathrm{Mgal} / \mathrm{d}$. About 30 percent of total 1980 pumpage for irrigation (370 Mgal/d) was withdrawn from Orange, Lake, Hillsborough, Highlands, and Brevard Counties in central Florida shown in the $60-90 \mathrm{Mgal} / \mathrm{d}$ range on plate 14 .

The other area of concentrated irrigation pumpage from in the Floridan is the rapidly developing 15-county Dougherty Plain area of southwest Georgia. Pumpage is concentrated in seven southwest Georgia counties where 1980 withdrawals aggregated about $200 \mathrm{Mgal} / \mathrm{d}$, or 15 percent of total 1980 irrigation pumpage from the Floridan.

Industrial and thermoelectric pumpage from the Floridan in 1980 (pl. 15) amounted to about $850 \mathrm{Mgal} / \mathrm{d}$. One-fourth of that pumpage, or about $210 \mathrm{Mgal} / \mathrm{d}$, was in Polk County, Fla., associated primarily with phosphate mining, chemical production, and citrus processing. Industrial pumpage in 1980 in Polk County was more than double the combined industrial and thermoelectric pumpage of any other county in the four states served by the Floridan. Glynn County in southeast Georgia (Brunswick) incurred the second highest rate of industrial and thermoelectric pumpage from the Floridan. About $87 \mathrm{Mgal} / \mathrm{d}$ were withdrawn, two-thirds of which was for pulp and paper processing.

Other pumping centers where at least $50 \mathrm{Mgal} / \mathrm{d}$ were withdrawn in 1980 for industrial and thermoelectric use include: Wayne County, Ga. $(70 \mathrm{Mgal} / \mathrm{d}$ for pulp and paper processing); Taylor County on Florida's northern Gulf coast (51 Mgal/d for pulp and paper processing); and Duval County, primarily the Jacksonville area $(50 \mathrm{Mgal} / \mathrm{d}$, nearly all of which was for pulp and paper processing).

Plates 12 to 15 showing the areal distribution of Floridan aquifer-system pumpage represent average annual withdrawal rates for 1980 . Seasonal variation in pumpage occurs in all of the major water-use categories. However, monthly ground-water pumpage in 1980 from all aquifers for public supply, rural use, industrial use, and thermoelectric power generation in Florida varied less than 9 percent from each respective annual average (Leach, 1983, tables 15, 16, 17, 19). Presumably, pumpage from the Floridan aquifer system for these uses throughout the region does not vary appreciably from one month to the next. In contrast, irrigation pumpage varies greatly throughout the year depending upon the temperature, timing of precipitation, crop type, soil characteristics, and method of irrigation. In the heavily irrigated central Florida area, withdrawals are highest in March, April, and May during the early part of the growing season when rainfall is scarce. In the Dougherty Plain irrigated area of Georgia, rainfall is 
more evenly distributed than in central Florida, and the growing season begins later. Heavy irrigation pumpage occurs in June, July, August, and early September.

\section{EFFECTS OF GROUND-WATER DEVELOPMENT}

REGIONAL WATER-LEVEL DECLINE

Plate 6 illustrates areas where pumping has caused long-term regional water-level decline in the Upper Floridan aquifer. Decline is the net difference between the estimated predevelopment potentiometric surface and the observed May 1980 potentiometric surface. Regional decline of at least $10 \mathrm{ft}$ has occurred in three areas: coastal Georgia, adjacent South Carolina, and northeast Florida; west-central Florida; and panhandle Florida. Plate 6 shows that, in most of the Upper Floridan aquifer, water levels have changed less than $10 \mathrm{ft}$ from their predevelopment altitudes. A few localized cones of depression where water-level decline has exceeded $10 \mathrm{ft}$ are too small to be shown at the scale of plate 6 .

The largest and oldest area of regional water-level decline occurs in southeast Georgia and adjoining Florida and South Carolina; the result of long-term pumping primarily for industrial use. Within this area, deep cones of depression have formed around pumping centers at Savannah and Fernandina Beach and shallow cones at Brunswick, Jesup, and Jacksonville. At Savannah, net decline at the center of the cone by 1980 was about $150 \mathrm{ft}$, which is equivalent to a water level of about $110 \mathrm{ft}$ below sea level. Warren (1944, fig. 7) presented a map of the decline of artesian water levels in coastal Georgia prior to 1942. His map shows that at Savannah the decline at the center of the cone had already approached $100 \mathrm{ft}$ by 1942 . Figure 29 is a longterm hydrograph of an Upper Floridan well located in the cone of depression at Savannah (location on pl. 6). The hydrograph shows the trend of water levels in the area from the mid-1950's to the early 1980's. The continual steady decline into the early 1960 's, followed by a flattening out of the water-level trend, conforms to the general trend of pumpage in the Savannah area and at the other major pumping centers in southeast Georgia as well, where industrial pumpage has not increased appreciably in 20 years.

At Fernandina Beach, net decline near the center of the cone by 1980 was about $100-120 \mathrm{ft}$, making the water level about 35-55 ft below sea level. Warren (1944) showed that at least $40 \mathrm{ft}$ of decline in the Fernandina Beach area had occurred by 1942. A 1959 potentiometric surface map of the area (Leve, 1961b, fig. 4) indicates a water-level decline from predevelopment of more than $60 \mathrm{ft}$ by that time (altitude 0 to
$-10 \mathrm{ft}$ ). The May 1980 potentiometric surface (pl. 5) shows no discernible change from the May 1974 potentiometric surface (Healy, 1975) in the Fernandina Beach area.

The amount of water withdrawn at Savannah in 1980 was less than that withdrawn at Brunswick, Fernandina Beach, or Jacksonville and about the same as that withdrawn at Jesup. The relative size of the cones of depression and the overall extent of the broad area of regional water-level decline reflect the transmissivity of the aquifer in the vicinity of each pumping center and the thickness and character of the upper confining unit (which dictate the potential for diverting natural discharge and increasing recharge to wells). Another factor at Jacksonville is that much of the pumping is from the Lower Floridan.

Transmissivity at Jesup, Brunswick, and Jacksonville is about four or five times larger than transmissivity at Savannah and Fernandina Beach (pl. 2). The southeast Georgia-northeast Florida area of regional waterlevel decline is coincident with a tightly confined part of the aquifer (pl. 1). Thus, the potential is low for appreciably increasing leakage from the surficial aquifer to the Upper Florician near the centers of pumping by increasing the head difference.

To compensate for small increases in leakage from the overlying surficial aquifer and small decreases in diffuse upward leakage per unit area near the several centers of pumping, water levels have declined over a very large area. Regional water-level decline stretches along the Atlantic coast about $150 \mathrm{mi}$ from Jacksonville to Hilton Head, S.C. and inland from the coast to a distance of about $60-110 \mathrm{mi}$.

The area of influence of pumping concentrated at Jacksonville, Fernandina Beach, and Brunswick has spread inland past the predevelopment ground-water divide between the Suwannee basin and the Southeast Georgia-Northeast Florida-south South Carolina Basin (fig. 22). The current divide is therefore southwestward of its predevelopment position, and a small amount of water that formerly discharged in the Suwannee basin has been diverted toward the coastal pumping centers. A comparison of plate 6 (net decline) and plate 1 (confined/unconfined area) shows that the area of influence of pumping in northeast Florida and southeast Georgia has spread southwest approximately to the boundary of semiconfined and unconfined conditions, where natural recharge is greater.

' The area to the north and west of the Savannah-Jesup pumping centers shows a somewhat different situation if plates 1 and 6 are compared. Except for areas around the Ocmulgee River (vicinity of Ben Hill County, Ga.) and north and northeast of Savannah (vicinity of Screven County, Ga., and Hampton and Beaufort 


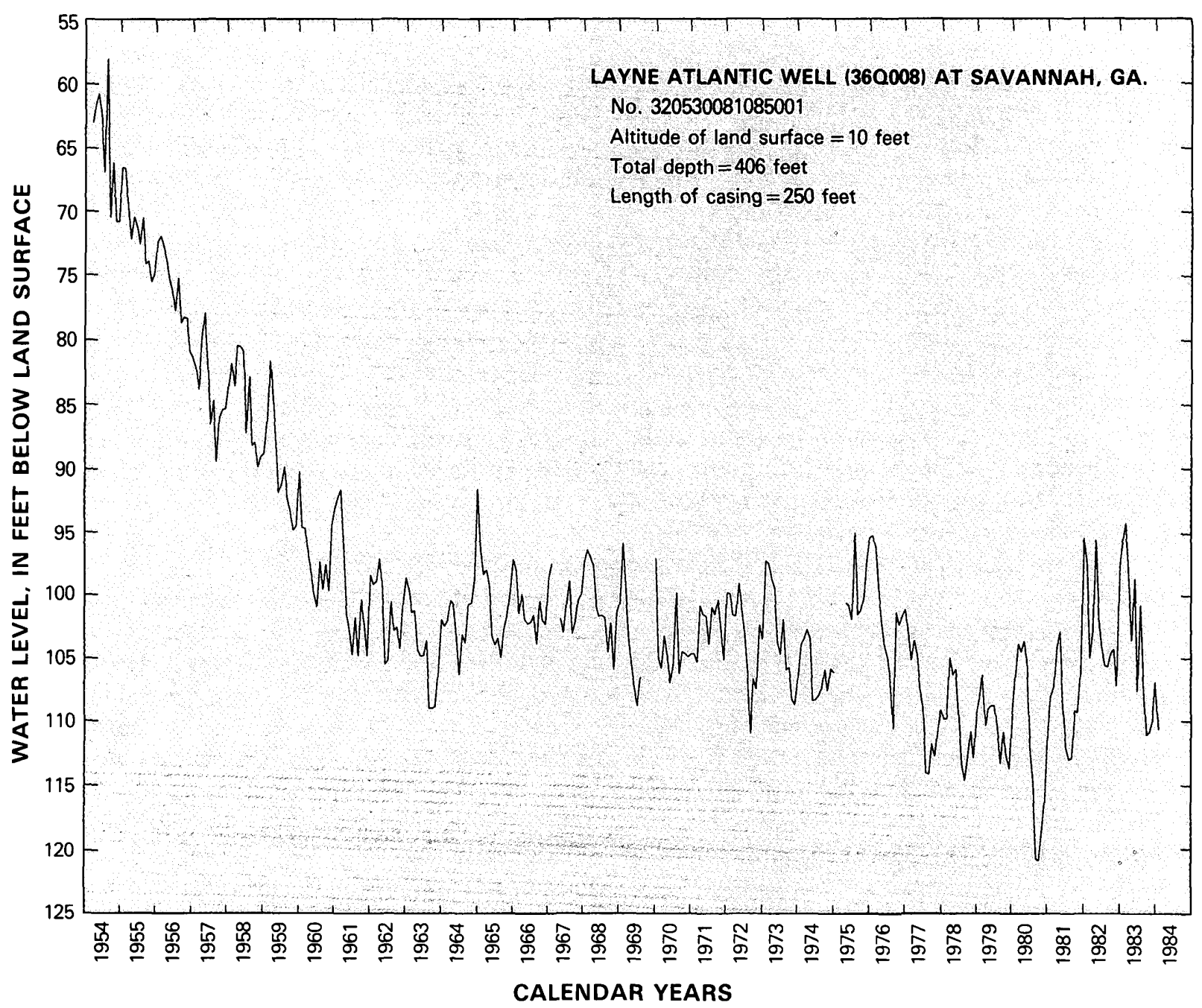

FIGURE 29.-Hydrograph of Upper Floridan aquifer well in southeast Georgia area of regional water-level decline.

Counties, S.C.), the water-level decline caused by pumping at Savannah and Jesup has not reached unconfined and semiconfined outcrop areas. Regional water-level decline stops in the area of the Gulf Trough, suggesting that the Trough, by its low transmissivity, continues to exert a damming effect on southeastward-flowing ground water, as it did in predevelopment time.

The area of regional water-level decline in west-central Florida (pl. 6) appears as one large cone of depression, its deepest part skewed to the northeast and centered in southwest Polk County. The long-term pumping associated with phosphate mining has been the dominant cause of the regional water-level decline. Maximum net decline between predevelopment and 1980 is estimated to be 50-60 ft. However, no closed cone of depression appears in the vicinity of southwest Polk County on the May 1980 potentiometric-surface map; only a distortion of the predevelopment contour configuration is evident, such that the hydraulic gradient south-southwest from the central Florida potentiometric high is much steeper in 1980 than in predevelopment time. A statewide map of the Upper Floridan potentiometric surface in July 1961 (Healy, 1962) shows little change from predevelopment (generally less than $10 \mathrm{ft}$ ) in west-central Florida. A second statewide map of the potentiometric surface in May 1974 (Healy, 1975) shows closed depressions in southwest Polk County, within which water levels were 20-30 ft lower than those in the same area in May 1980.

The long-term trend of Upper Floridan water levels is shown by the hydrograph in figure 30 from a well close to the area of maximum decline (location on pl. 6). The representative hydrograph shows water levels dropping by more than $40 \mathrm{ft}$ from the late 1950's (waterlevels similar to predevelopment) to 1966-67, the period of maximum pumpage. The hydrograph shows a generally rising trend into the early 1980's following a record low in the spring of 1975 , which is consistent with the 


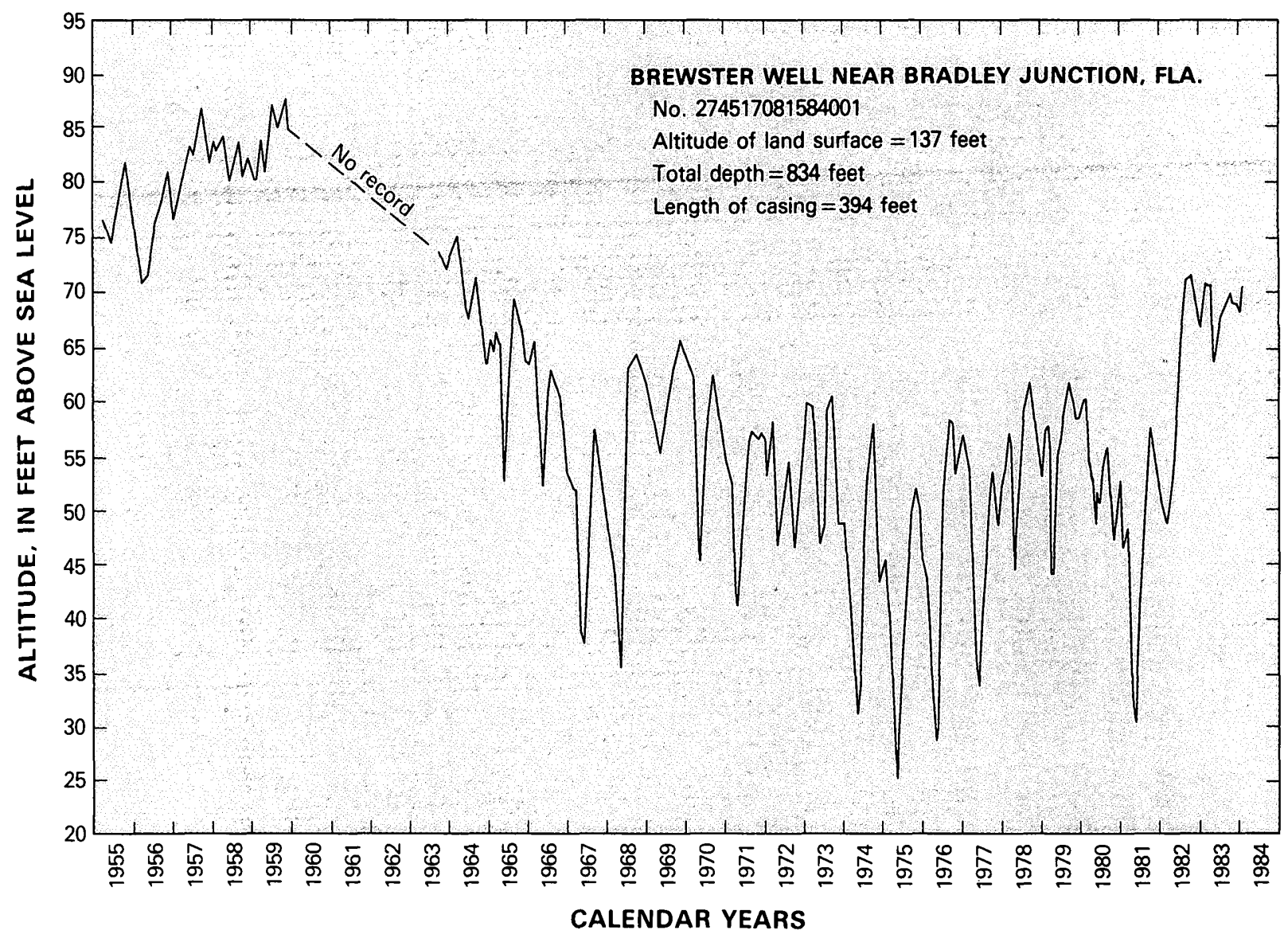

FIGURE 30.-Hydrograph of Upper Floridan aquifer well in west-central Florida area of regional water-level decline.

decline of industrial pumpage during the same period. Excess rainfall in the late 1950's and deficient rainfall in many of the subsequent years up to the late 1970's also influences this hydrograph (Ryder, 1985).

The pumpage that has caused the regional water-level decline in west-central Florida is greater than the pumpage that is responsible for the regional decline centered in southeast Georgia; yet the breadth and depth of regional decline in west-central Florida is considerably less than that of regional decline centered in southeast Georgia. The main reason for smaller water-level declines in west-central Florida is that the area has greater potential for increasing recharge, and diverting natural discharge, to wells. Comparing the map of net decline (pl. 6) to the map of confined/unconfined conditions (pl. 1) shows that most of the area of net decline in west-central Florida is under confined conditions, but the leakage coefficient of the upper confining unit (pl. 3 ) is generally one to two orders of magnitude greater in west-central Florida than in southeast Georgia and northeast Florida. Comparison of plates 1 and 6 also shows that the center of heaviest pumpage in southwest Polk County is very close to an area of semiconfined and unconfined conditions, thus enhancing the potential for increased leakage. The proximity of semiconfined and unconfined conditions to the center of heaviest pumpage is probably the main reason for the skewed, rather than concentric, configuration of net decline in west-central Florida.

The area of regional water-level decline centered around Fort Walton Beach in the Florida panhandle seems disproportionately large for the pumpage there $(20 \mathrm{Mgal} / \mathrm{d})$, which is less than 5 percent of the pumpage responsible for the regional decline in southeast Georgia-northeast Florida and west-central Florida. The Fort Walton cone is nearly the size of that in westcentral Florida and nearly three times as deep. Maximum decline between predevelopment and 1980 water levels near Fort Walton Beach was more than $140 \mathrm{ft}$, which is equivalent to a water level more than $100 \mathrm{ft}$ below sea level.

Measurable water-level decline in the vicinity of Fort Walton Beach began in the 1940's. Figure 31 is a longterm hydrograph of an Upper Floridan well about $12 \mathrm{mi}$ north of Fort Walton Beach (location on pl. 6) that shows the trend of water levels in the area since 1947. 


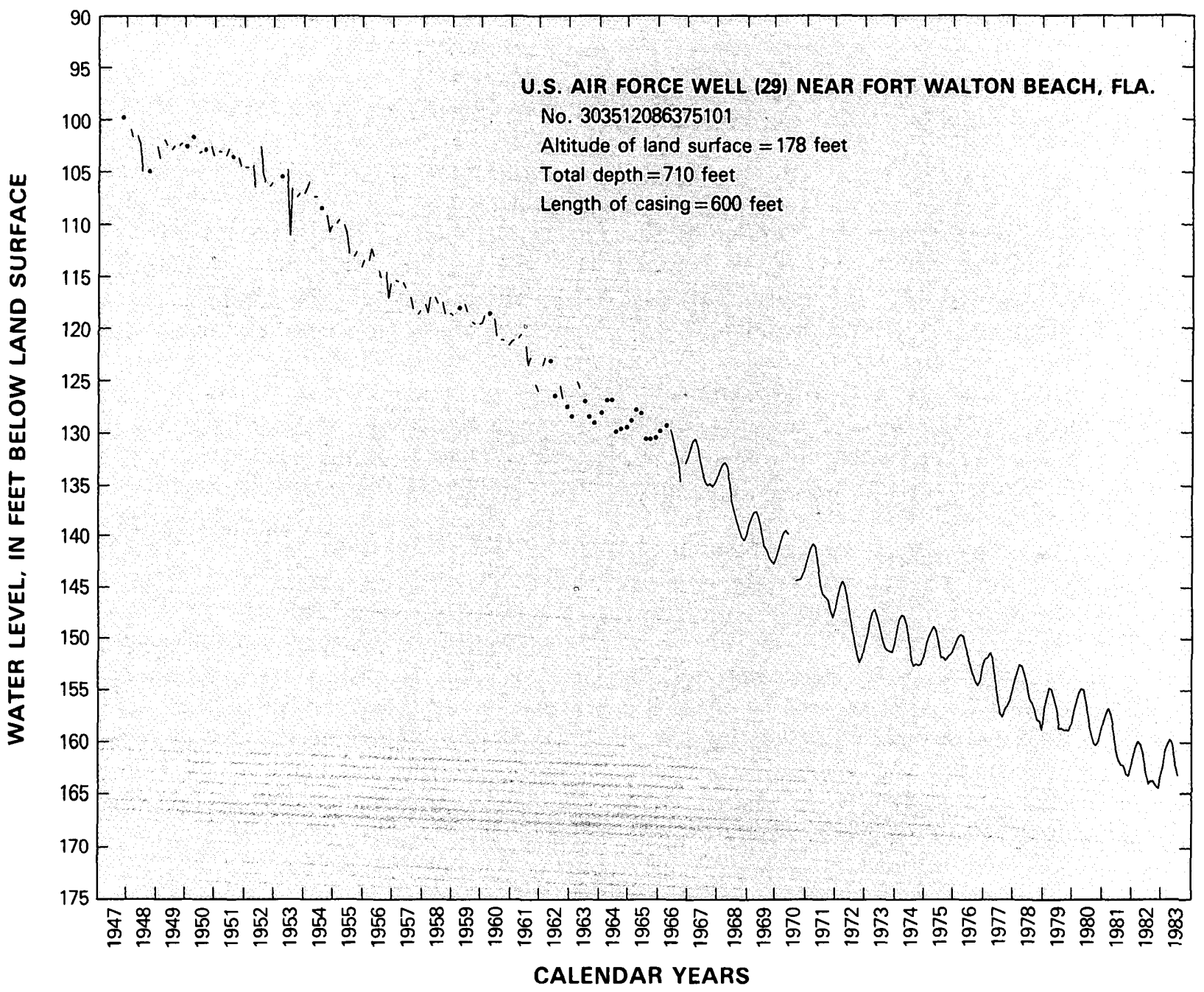

FIGURE 31.-Hydrograph of Upper Floridan aquifer well in panhandle Florida area of regional water-level decline.

Unlike the hydrographs of representative wells in the two other areas (figs. 29 and 30), the hydrograph in figure 31 shows contining water-level decline into the 1980 's. The transient response time due to changes in pumpage is probably greater in the Fort Walton Beach area than in any other part of the Floridan aquifer system; however, the steady downward trend of water levels probably reflects continual increases in pumpage over time.

The large water-level decline in the Fort Walton Beach area relative to the pumpage that caused it is due to low transmissivity and inability to divert recharge or decrease discharge nearby. Transmissivity in much of the area of water-level decline is less than $10,000 \mathrm{ft}^{2} / \mathrm{d}$ and only about $2,000 \mathrm{ft}^{2} / \mathrm{d}$ at the center of pumpage. Confinement in the vicinity of Fort Walton Beach is at least as tight as in any other part of the aquifer system. The area of appreciable water-level decline appears to have spread eastward to a region of semiconfined conditions. However, the very low transmissivity between this region and the center of pumpage impedes the movement of water from the semiconfined region to the pumping wells. The longterm hydrograph in figure 31 suggests that the area of water-level decline in panhandle Florida continues to enlarge. Because of the proximity of semiconfined conditions to the east, the panhandle area of decline is expected to grow less rapidly in that direction than others; this is implied by the steeper gradient of decline east of the Fort Walton Beach area on plate 6.

The west-central Florida and northeast Floridasoutheast Georgia areas of water-level decline appear to be reasonably stable in the early 1980's, primarily because concentrated industrial pumpage has leveled off. However, as figure 24 shows, combined pumpage from the Floridan aquifer-system grows each year. Because a large part of the increase in pumpage in recent years has been for irrigation, which tends to be 
seasonal and widely dispersed, the long-term effect of steadily increasing withdrawals on water levels in these two areas has not been major.

RECHARGE, DISCHARGE, AND DISTRIBUTION OF FLOW

Ground-water development in the Floridan aquifer system has not had a major impact on regional recharge, discharge, and the distribution of flow. Simulation of pumpage of $2,700 \mathrm{ft}^{3} / \mathrm{s}$ indicates that development has caused the total recharge area to expand from about $67,000 \mathrm{mi}^{2}$ before development to about $76,000 \mathrm{mi}^{2}$. Simulated recharge to, and therefore discharge from, the aquifer system increased from a predevelopment total of about $21,500 \mathrm{ft}^{3} / \mathrm{s}$ to about $24,000 \mathrm{ft}^{3} / \mathrm{s}$. The fact that the area over which recharge occurs has increased by about the same percentage as the recharge results in a current average recharge rate about the same as the predevelopment rate-about 5 in./yr.

Upper Floridan spring discharge is still the dominant feature of the present flow system as it was prior to development. Primarily because major pumping centers are located away from major springs, the total aquifer discharge to springs and surface-water bodies has not been measurably affected by ground-water development. Comparison of recent mean discharges of 24 of Florida's largest springs with measurements made during or prior to the early 1930's (Stringfield, 1936, p. 155, 156) showed virtually no decrease in flow. Locally, however, ground-water development or natural factors have affected the discharge of individual springs. The most notable example is Kissengen Spring in the Polk County pumping center where head has declined about $50 \mathrm{ft}$. The spring ceased flowing in February 1950 after a 40-yr flow record of $15 \mathrm{ft}^{3} / \mathrm{s}$ or more (Rosenau and others, 1977, p. 307). Tibbals (in press) notes that the long-term average discharges of Wekiva Springs and Rock Springs in Orange County, Fla., appear to have actually increased since about 1960, despite belownormal rainfall and increased pumping in the area. Tibbals suggested that the increased spring flow is due to flushing of silt and debris from the springs' vents during the period of record high flows in 1960.

Simulation of $2,700 \mathrm{ft}^{3} / \mathrm{s}$ pumpage caused a 4.5 percent drop in total simulated spring flow and discharge to surface-water bodies, from about $19,000 \mathrm{ft}^{3} / \mathrm{s}$ to about $18,100 \mathrm{ft}^{3} / \mathrm{s}$. Simulated diffuse upward leakage dropped 29 percent from about $2,550 \mathrm{ft}^{3} / \mathrm{s}$ to about $1,800 \mathrm{ft}^{3} / \mathrm{s}$. The figures imply that pumping from the Floridan diverts roughly similar quantities of water from spring flow and discharge to surface-water bodies, and diffuse upward leakage; but on a percentage basis, pumping has had a substantially greater effect on diffuse upward leakage.

The areal distribution of current recharge is quite similar to that of predevelopment recharge shown on plate 11. Particularly, the distribution of high recharge in unconfined and semiconfined areas near large springs, and streams and lakes receiving Floridan discharge, remains virtually unchanged.

Changes in the rates of recharge and discharge (as diffuse upward leakage), and former discharge areas that have become recharge areas as a consequence of development, are shown on plate 16. Maximum change has occurred in the west-central Florida area. Areas where the simulated recharge rate has increased or the upward leakage rate has decreased by 5-10 in./yr are the northwest Hillsborough-south central Pasco County area of public supply wells, central Hillsborough County area of industrial pumping, southwest Polk County area of industrial pumping, and central Highlands County area of irrigation pumping. The unconfined and semiconfined conditions in the northern part of west-central Florida and a relatively leaky upper confining unit in the southern part favor the increase in recharge rates.

Minimal increases in recharge or reductions in discharge have occurred in the area of water-level decline centered in southeast Georgia. In that area, the tight confinement impedes recharge and causes the broad extent of water-level decline.

Although the vertical gradient has been reversed over much of the area of regional water-level decline in panhandle Florida, increased recharge and (or) reduced discharge is extremely low $-a$ fraction of an inch per year or less. Vertical leakage rates are compatible with the large area of water-level decline, relative to the low pumping rate, and the very tight upper confining layer.

Moderate increases in recharge or reductions in discharge (1-5 in./yr) have been caused by ground-water withdrawals in the corridor stretching from west-central Florida to northeast Florida. Similar changes are associated with irrigation pumping in the Dougherty Plain area of southwest Georgia. But over most of the area underlain by the Floridan, the distribution of natural recharge and discharge (both diffuse and point) is about the same as it was before ground-water development.

Figure 22 illustrating predevelopment flow conditions showed the predominance of spring discharge and discharge to surface-water bodies over diffuse upward leakage in every ground-water basin except south Florida. Figure 32 is a companion illustration for current conditions showing the percentage of simulated discharge in each of eight ground-water basins that is accounted for by pumpage or the two types of natural discharge. 


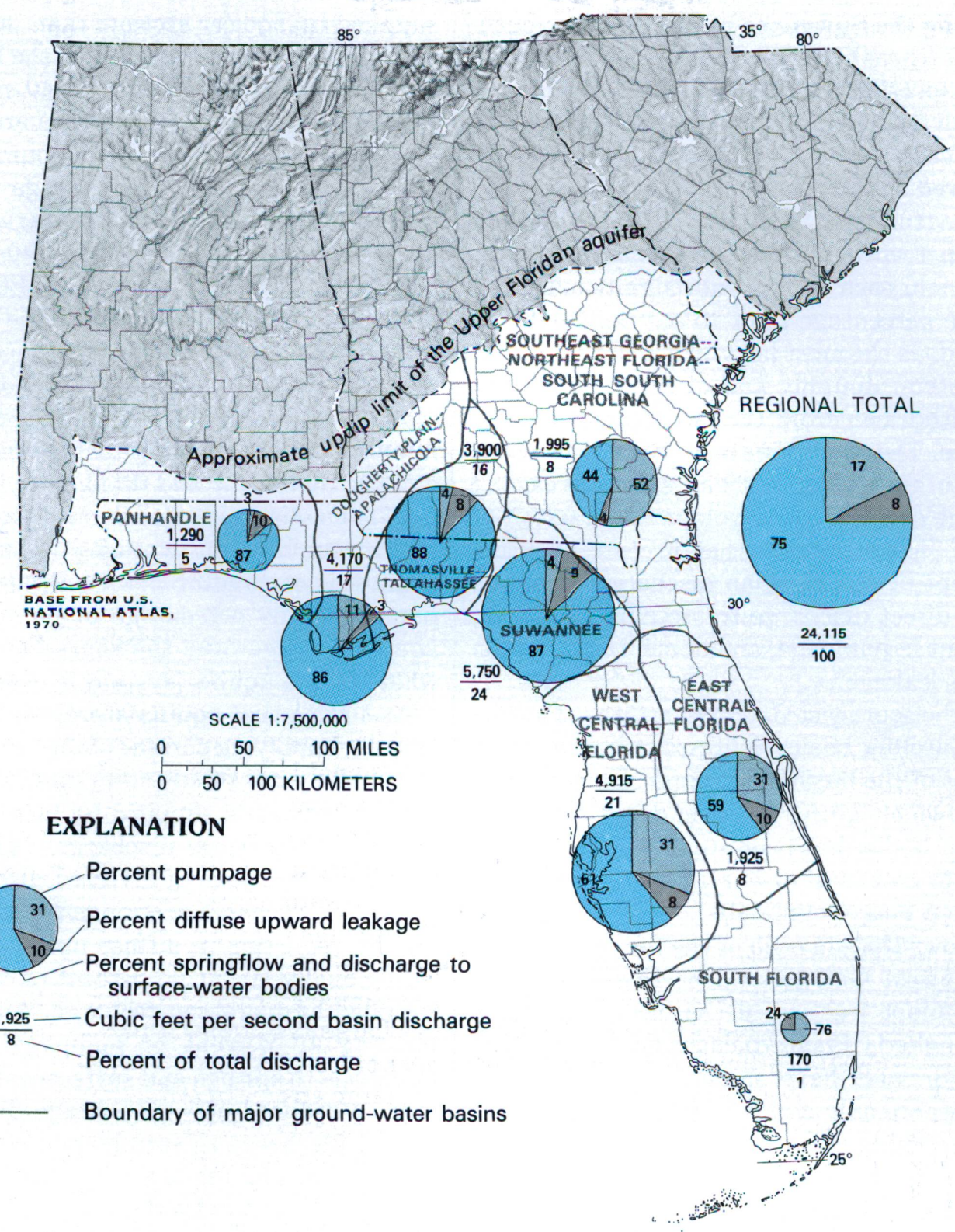

FIGURE 32.-Estimated current (about 1980) discharge from major ground-water basins of the Upper Floridan aquifer.

Several facts about the current flow system become apparent when figures 22 and 32 are compared: (1) Regionally, spring flow and discharge to surface-water bodies is the predominant form of discharge from the current flow system, as it was from the predevelopment flow system; simulation suggests that about threefourths of all current discharge leaves the aquifer system as spring flow or discharge to surface-water bodies. The remaining fourth of the Floridan discharge is split between pumpage (17 percent of total discharge) and diffuse upward leakage (8 percent of total discharge). (2) Pumpage is now a major part of aquifer discharge, especially in four of the basins. (3) Diffuse upward leakage is markedly reduced from predevelopment rates in two basins where flow is sluggish (southeast Georgia-northeast Florida-south South Carolina, and south Florida); but regionally, diffuse upward leakage is not greatly reduced. (4) Ground-water development has not resulted in significant movement of the divides separating the eight major ground-water basins. The only noticeable change in the position of basin divides has been the southwesterly movement of the 
divide separating the Suwannee basin from the southeast Georgia-northeast Florida-south South Carolina basin. Close inspection of figures 22 and 32 will also show that the divide between the west-central Florida basin and the east-central Florida and south Florida basins has moved slightly southeast, thereby slightly enlarging the southern part of the west-central Florida basin. (5) The percentage of total Floridan discharge that now occurs in each basin is not significantly different from the percentage prior to development.

Central Florida is the most heavily developed part of the aquifer system. Roughly half of current Floridan pumpage is withdrawn from the two central Florida basins combined. The two basins now account for about 29 percent of total Floridan discharge, an increase of about 4 percent over the predevelopment fraction of total discharge. Figure 32 shows that, in central Florida, about 60 percent of the Floridan discharge occurs as spring flow or direct discharge to streams and lakes, about 30 percent is pumpage, and about 10 percent is diffuse upward leakage.

Pumpage in the southeast Georgia-northeast Floridasouth South Carolina basin comprises slightly more than 50 percent of the basin's discharge. This basin is the only one in which spring flow and direct discharge to surface-water bodies has been supplanted by pumpage as the major means of discharge. Diffuse upward leakage has been nearly eliminated.

Figure 32 shows that, in each of the four contiguous basins of southwest Georgia and northwest Florida, pumpage is a minor fraction of the basin discharge. Even in the Dougherty Plain-Apalachicola basin, where irrigation withdrawals have soared in recent years, pumpage represents only about 11 percent of average basin discharge. Spring flow plus discharge to lakes and streams comprises 85-90 percent of current discharge in each of the four basins.

In terms of flow, the south Florida basin is an insignificant part of the Floridan aquifer system, as it was during predevelopment time. Discharge is only about 1 percent of total Floridan discharge. Pumpage in the basin, nearly all of which is agricultural and poorly documented, has superseded diffuse upward leakage as the principal means of discharge.

Most of the water withdrawn from the Floridan aquifer system since development began has been supplied by increased recharge and the diversion of natural discharge. The amount of water contributed by aquifer storage in the Floridan has been minimal. The minor role of storage in supplying pumpage is illustrated by conditions in the Fort Walton Beach area of panhandle Florida. There low transmissivity and tight confinement result in proportionately more water pumped from wells supplied by aquifer storage than in any other part of the aquifer system. Pumpage in the Fort Walton Beach area beginning in the early 1940's grew to about 16 Mgal/d by the early 1980's. The area of influence (including offshore area) of that pumping by the early 1980 's is about $3,000 \mathrm{mi}^{2}$; average water-level decline is about $60 \mathrm{ft}$. Assume that the average area of influence and water-level decline over the 40-yr period between predevelopment and current conditions are 1,500 $\mathrm{mi}^{2}$ and $30 \mathrm{ft}$, respectively, and that the storage coefficient is $4 \times 10^{-4}$. An estimate of the contribution of aquifer storage to average pumpage during the period of pumping can be obtained by multiplying the average area of influence by the average water-level decline by the storage coefficient and dividing by the time of pumping. The estimated contribution from aquifer storage to an assumed 40-yr average pumping rate of $8 \mathrm{Mgal} / \mathrm{d}$ using this calculation is $0.26 \mathrm{Mgal} / \mathrm{d}, 3$ percent of the pumpage. The percentage of pumpage derived from aquifer storage over the course of development elsewhere in the aquifer system is even less.

Assuming that aquifer storage is a negligible source of water supplying current pumpage, the Floridan is approximately in a steady-state condition. Therefore, nearly all pumpage is supplied by increased recharge and diversion of natural discharge. Figure 33 shows the simulated fractions of diverted discharge supplied by salvage of discharge to springs and surface-water bodies and by reduction in diffuse upward leakage.

Regionally, about 60 percent of current pumpage is supplied by increased recharge. About half of the remaining 40 percent of pumpage is salvaged from discharge to springs and surface-water bodies, and half is from reduced upward leakage. Because the overall rate of discharge to springs and surface-water bodies is so much greater than the rate of diffuse upward leakage, ground-water development has reduced predevelopment spring flow and discharge to surface-water bodies by less than 5 percent; whereas the rate of diffuse upward leakage has been reduced by about 30 percent. Decreases in spring flow and discharge to surface-water bodies are minimal in the southeast Georgia-northeast Florida-south South Carolina basin and negligible in the panhandle basin because centers of pumpage are far removed from the unconfined and semiconfined areas where point discharges occur. In two basins, the Thomasville-Tallahassee and the Suwannee, increased recharge contributes less than half of the water that supplies pumpage; salvage from spring flow and discharge to surface-water bodies contributes the major share. In those basins where generally unconfined conditions occur, recharge cannot be increased by increasing the downward hydraulic gradient between the 


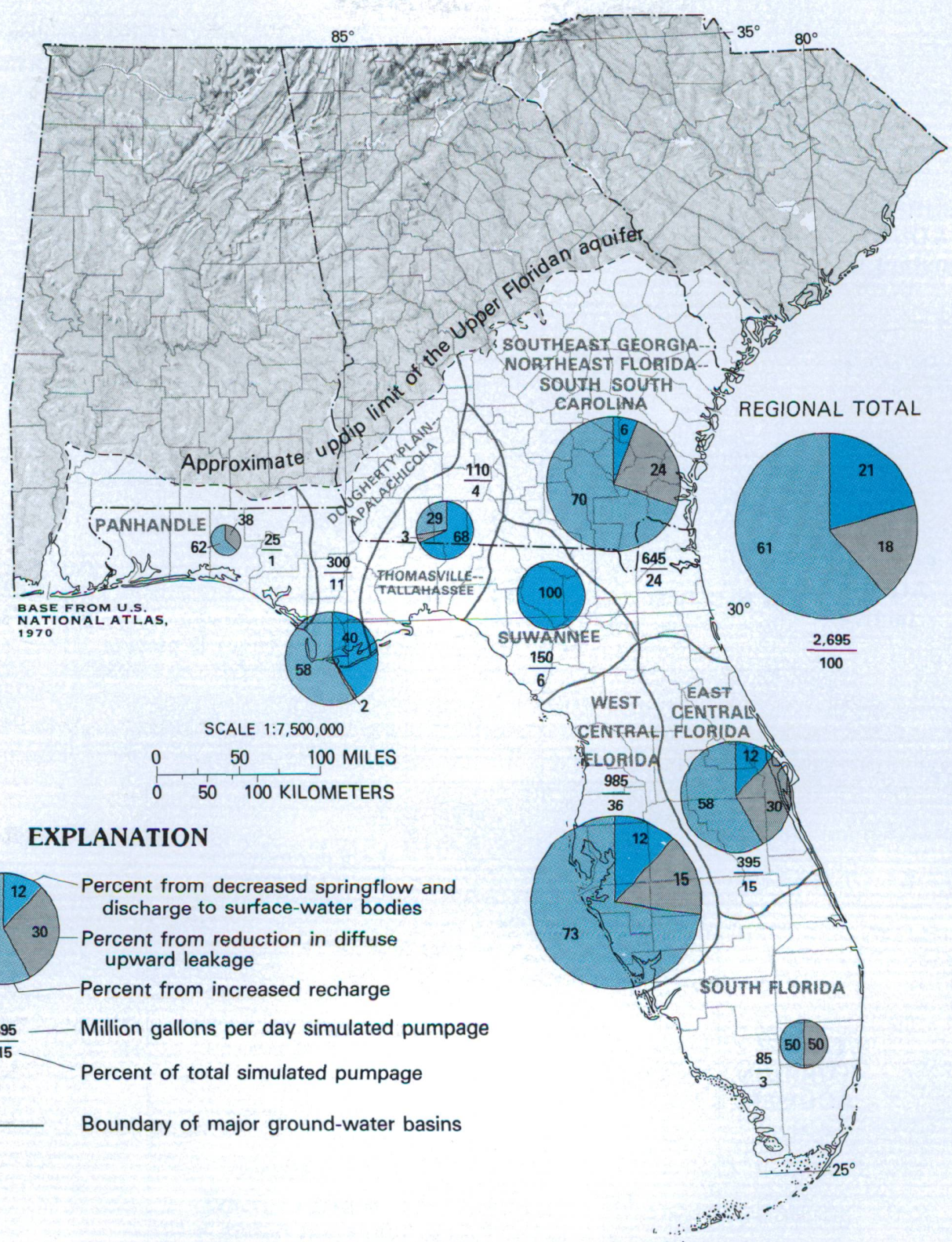

FIGURE 33.-Sources of water supplying simulated pumpage (about 1980) from the Floridan aquifer system (assuming steady-state conditions).

surficial aquifer and the Upper Floridan because the surficial aquifer, if it exists, is highly permeable; its water table and the potentiometric surface of the Upper Floridan are nearly coincident. Thus, the principal mechanism for supplying water to wells must be diversion of natural discharge, of which spring flow and discharge to surface-water bodies is the most prevalent source.

Figure 34 shows the simulated components of flow among units associated with the Floridan aquifer system under current flow conditions. Figure 34 is similar to figure 23 showing these flow components for predevelopment conditions. In addition figure 34 shows the percentage of change in each flow component resulting from simulated ground-water development. The changes in the discharge to springs and surfacewater bodies and diffuse upward leakage from the Upper Floridan have been discussed previously. Downward leakage to the Upper Floridan, which accounts for 97 percent of simulated current recharge (lateral 


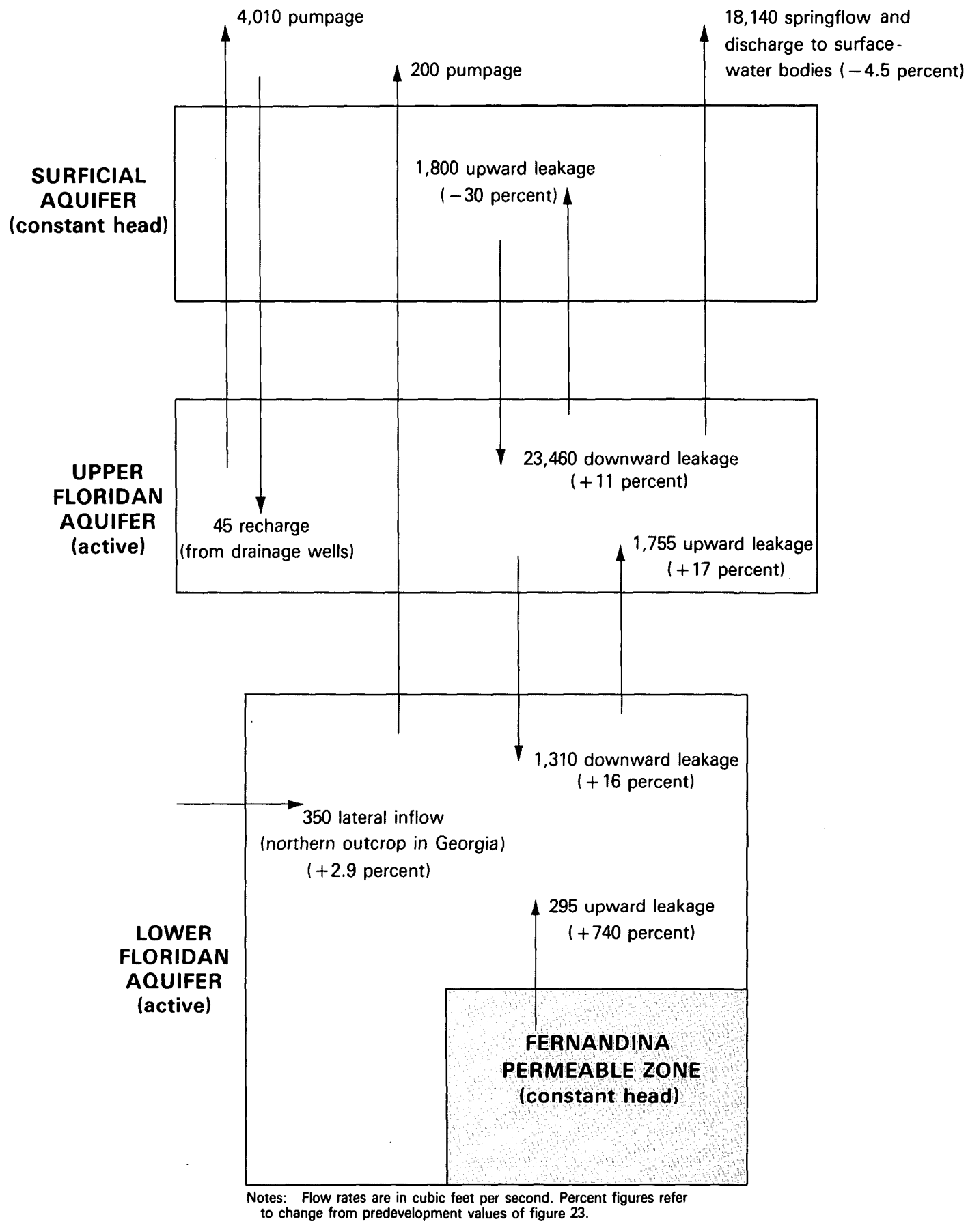

FIGURE 34.-Simulated components of flow (about 1980) among units associated with the Floridan aquifer system.

inflow from adjacent sand aquifers in the northern outcrop area of Georgia and upward leakage from the Fernandina permeable zone account for the remaining 3 percent), has increased about 11 percent over the predevelopment rate. Simulation indicates that groundwater development has caused the rates of both downward and upward leakage between the Upper
Floridan and Lower Floridan to increase about 16 percent. Lateral inflow to the Floridan in the northern Georgia outcrop has not changed significantly from its predevelopment rate.

The flow model indicates a very large change in the rate of upward leakage from the Fernandina permeable zone following development. Pumping at Jacksonville, 
Fernandina Beach, and Brunswick has increased the vertical hydraulic gradient from the Fernandina permeable zone to overlying parts of the Lower Floridan. Little is known of the Fernandina permeable zone beyond the fact that it is a deep water-bearing zone that presently contains moderately to very saline water. The key unanswered question regarding the zone is whether or not it currently has a source of freshwater recharge. If the answer is no, then presumably a finite volume of remnant saline water is being continually depleted and replaced by water of higher chloride concentration. If the answer is yes, a logical source is the updip sandy equivalents of the Fernandina permeable zone. This source would necessitate a very long flow path from sand aquifer outcrops downgradient to the Fernandina permeable zone.

\section{SALTWATER ENCROACHMENT}

The development of ground water in coastal areas of the Floridan aquifer system changes the sensitive balance between freshwater and the slightly more dense saltwater beneath it. If an area of reduced head caused by pumping spreads into a saltwater zone and if a gradient from the saltwater zone to the pumping wells is thus created, the potential for movement of saltwater to the pumping wells exists. Whether or not that potential becomes a practical reality depends on the horizontal and vertical permeability of the rocks separating the pumping wells from the saltwater zone.

In general, the potential for saltwater contamination of coastal freshwater supplies is greater in unconfined and semiconfined parts of the system than in confined parts. This is because relatively low predevelopment heads associated with unconfined and semiconfined areas have allowed the freshwater-saltwater interface, or transition zone, to establish its equilibrium position at higher altitudes than those associated with the interface position in confined areas; the coastal freshwater section is thus thinner to begin with, before pumping, than is the section in confined areas.

The movement of high-chloride water toward pumping wells in the Floridan can be either lateral or vertical or a combination of the two. Determining whether encroachment is more from a lateral or vertical direction is often difficult in unconfined and semiconfined coastal areas because of the proximity of the sloping interface to shore. In confined areas where the interface is deeper and farther from shore, encroachment is vertical from below.

In studies that involve ground water in coastal areas, the Hubbert interface equation (Hubbert, 1940, p. 864) is used to estimate the altitude of the freshwatersaltwater interface. The general Hubbert interface equation in terms of head is

$$
Z=\frac{\rho_{s}}{\rho_{s}-\rho_{f}} \cdot h_{s}-\frac{\rho_{f}}{\rho_{s}-\rho_{f}} \cdot h_{f}
$$

where $Z=$ elevation of freshwater-saltwater interface above a datum (L),

$\rho_{s}=$ density of saltwater (formation water beneath interface) $\left(\mathrm{M} / \mathrm{L}^{3}\right)$,

$\rho_{f}=$ density of freshwater (formation water above interface) $\left(\mathrm{M} / \mathrm{L}^{3}\right)$,

$h_{s}=$ saltwater head (head beneath the interface) (L), and

$h_{f}=$ freshwater head (head above the interface) (L).

A usual assumption in the application of the Hubbert interface equation is that the underlying saltwater is static. If this assumption is made and a sea-level datum is chosen, then the saltwater head $\left(h_{s}\right)$ in the general Hubbert interface equation equals zero. The first term of the equation thus drops out, leaving a "special case" Hubbert interface equation computationally equivalent to the familiar Ghyben-Herzberg equation (Badon Ghyben 1889; Herzberg, 1901, in Cooper and others, 1964), which is based on the occurrence of hydrostatic conditions in both the freshwater and saltwater zones.

The assumption of static saltwater, implying a stable interface, was judged acceptable for locating the seaward extent of freshwater flow for the regional flow model. But in real coastal aquifers, the assumption of static saltwater rarely, if ever, applies, even with no ground-water development (Cooper, p. C1-C4 in Cooper and others, 1964). The error incurred in assuming static saltwater, while tolerable on a regional scale, is unacceptable on a local scale in areas where pumping has caused a gradient from a saltwater zone to the pumped wells. Thus, to accurately define an interface position in a coastal aquifer where neither the freshwater nor the saltwater is static, the more general Hubbert interface equation must be used rather than the special case of the Hubbert equation (Ghyben-Herzberg equivalent).

Application of the general Hubbert equation to coastal saltwater encroachment problems is usually not possible because, as can be seen from the equation, the saltwater head and density are required, in addition to the freshwater head and density. In most field situations, wells from which head and water samples for density analysis can be obtained only penetrate the freshwater zone above the interface. Without the wells from which to collect the required data, comprehensively describing the relation between freshwater and saltwater in most coastal areas of the Floridan has been virtually impossible.

Increases in chloride concentration in coastal wells open to freshwater zones are confirmation of saltwater encroachment, but the areal extent of vertical or lateral 
interface movement associated with an increase in chlorides is very difficult to document. For this reason, the remainder of this section is a generalized summary of saltwater encroachment in the Floridan rather than a quantitative discussion describing the extent of vertical and lateral interface movement.

Among semiconfined coastal areas of the Floridan that have experienced saltwater encroachment as a result of pumping, probably none has received more study than the Savannah area of Georgia and South Carolina. Relatively detailed accounts of the movement of saltwater due to pumping in the area can be found in Counts and Donsky (1963), McCollum and Counts (1964), McCollum (1964), and more recently Hayes (1979). Plate 1 shows the area of semiconfined conditions along the South Carolina coast northeast of Savannah. The predevelopment potentiometric surface map (pl. 4) shows that, before pumping in the Savannah area, the direction of ground-water flow was from the outcrop area east-southeast to the natural discharge area coincident with the semiconfined area along the South Carolina coast.

The May 1980 potentiometric surface map (pl. 5) shows that pumping in the Savannah area has reversed the original seaward hydraulic gradient, and the present direction of flow is southwest from the semiconfined South Carolina coastal area toward Savannah. The concensus among the reports cited above is that highchloride water is probably entering the Upper Floridan aquifer in the vicinity of Port Royal Sound, particularly on the northeast side of Parris Island. Confinement of the Upper Floridan in the estuaries northeast of Parris Island is reported to be minimal (Hayes, 1979, p. 67). However, the movement of high-chloride water toward the Savannah pumping center is extremely slow, and evidence of saltwater encroachment has been inconclusive. Chloride concentrations in samples from selected Upper Floridan wells on the north end of Hilton Head Island have increased slightly (less than $100 \mathrm{mg} / \mathrm{L}$ ) since the early 1960's (Hayes, 1979, table 14; fig. 24). The chloride concentration in one well on the extreme north end of the island open to the upper part of the Upper Floridan increased from about $100 \mathrm{mg} / \mathrm{L}$ in 1978 to about $600 \mathrm{mg} / \mathrm{L}$ in 1983 (Clark and others, 1984, p. 135). Local pumpage on Hilton Head, and possible breaches in aquifer confinement offshore east of the island, may be contributing to the inland movement of saltwater (McCollum, 1964; Hayes, 1979, p. 69).

Volusia County, Fla., is another semiconfined area along the Atlantic coast that has experienced saltwater encroachment as a result of ground-water development. As in coastal South Carolina, predevelopment heads of about $10 \mathrm{ft}$ above sea level in coastal Volusia County were among the lowest heads in the Upper Floridan aquifer anywhere along the Atlantic coast. The predevelopment interface was probably no more than 400-500 ft below sea level at the shoreline.

The history of municipal water supply at Daytona Beach is a series of well fields abandoned to saltwater intrusion, followed by or concurrent with construction of new wells ever farther inland from the coast. Black and others (1953) provided a chronology up to the early 1950's. The original mainland well field, tapping the uppermost part of the Upper Floridan, was located about $1.5 \mathrm{mi}$ inland from the ocean; it served the city from 1909 until 1936. This well field was supplemented by a group of seven wells constructed on the barrier island in the 1920's. Black and others $(1953$, p. 30$)$ stated that, by 1949 , "serious" saltwater intrusion had developed in four of the barrier island wells. Use of the barrier island wells was discontinued in the 1950's. Whether actual saltwater encroachment into the original mainland well field had occurred, when operation of a new mainland well field located about $2.5 \mathrm{mi}$ inland began in 1936, is unclear. Nevertheless, use of the original wells ceased at that time.

The influence of well depth on saltwater encroachment in coastal Volusia County is illustrated by an early experience with the then-new Daytona Beach mainland well field, recounted by Black and others (1953, p. 30):

Within a few weeks after the new well field was placed in operation, the presence of salt water intrusion was apparent and careful tests showed that it had taken place only in wells 1 and 10, which had been drilled approximately $50 \mathrm{ft}$ deeper [to 250 and $254 \mathrm{ft}$ ] than the other wells.

In response to increased demand, this well field was expanded westward in 1949. By 1954 , a concentric pattern of upconing of salty water beneath the Daytona Beach well field was evident (Wyrick, 1960, fig. 24). Eventually, use of this well field was reduced and it was finally abandoned altogether as new wells still farther west were drilled. By the early 1980's, new municipal wells as far as $10 \mathrm{mi}$ inland from the coast were put into use (A. T. Rutledge, U.S. Geological Survey, written commun., 1984).

Saltwater encroachment and subsequent construction of new wells farther inland from the coast has been repeated (although on a lesser scale because demand for water is less) in a number of smaller coastal communities in Volusia County, including Holly Hill, New Symrna Beach, and Port Orange. By the early 1989's, New 
Symrna Beach was also constructing supply wells nearly $10 \mathrm{mi}$ inland from the coast to escape encroaching saltwater (A. T. Rutledge, U.S. Geological Survey, oral commun., 1984).

On the Gulf coast of peninsular Florida, ground-water development has cause saltwater encroachment locally in the semiconfined Upper Floridan at Tampa Bay. Both the cities of St. Petersburg and Tampa were forced to abandon their original downtown municipal well fields many years ago because of saltwater intrusion. Black and others $(1953$, p. 23$)$ reported that all of the (mostly industrial) wells in downtown Tampa for which records were available (late 1940's or early 1950's) yielded water containing "relatively high" chloride concentrations and that many had been abandoned. They further stated (p. 23) that "most of downtown Tampa is salted to such an extent that well water is not potable."

By the early 1950's, a number of areas on the Pinellas County peninsula had also experienced saltwater encroachment: Heath and Smith $(1954$, p. 34) mentioned a small area south of Palm Harbor, most of the area in the vicinity of Indian Rocks Beach and Walsingham, a strip about a mile wide along the southeast coast of the peninsula, and a small area at the north end of Old Tampa Bay about $2 \mathrm{mi}$ west of Oldsmar.

Unconfined and semiconfined conditions along the Gulf coast of peninsular Florida north of Tampa Bay and in parts of west Florida make this long coastal area particularly vulnerable to saltwater encroachment. But because ground-water development is minimal in the area, no regional saltwater intrusion has been documented. Evidence of local encroachment into coastal wells in the New Port Richey area of Pasco County and at Cedar Key in Levy County to the north has been noted by Black and others (1953). They also reported the early abandonment to saltwater intrusion of selected industrial wells near the coast at Panama City in Bay County.

The area of regional water-level decline in west-central Florida reaches the Gulf coast from Hillsborough County south to Charlotte County. Wilson (1982) documented the results of a recent study to estimate the regional effects of projected withdrawals in the area on the saltwater front in the Floridan. He concluded that the present saltwater front, defined by the $19,000 \mathrm{mg} / \mathrm{L}$ line of equal chloride concentration in the lower part of the Upper Floridan, corresponds closely to a theoretical predevelopment equilibrium position of a freshwatersaltwater interface calculated using the GhybenHerzberg assumption. Wilson (1982) further concluded that net landward movement of the saltwater front is probably occurring under existing conditions, but rates of movement are so slow that on a regional basis saltwater encroachment under existing and projected conditions to the year 2000 is not a threat to the existing freshwater resources in the Floridan.

Among confined areas of the Floridan aquifer system, only the Brunswick, Ga., area has experienced significant saltwater encroachment as a result of ground-water development. High predevelopment freshwater heads in the Upper Floridan aquifer along the tightly confined southeast Georgia-northeast Florida coast ensured that the predevelopment freshwater-saltwater interface was relatively deep at the shoreline and far offshore near the top of the aquifer. The results of recent hydrologic testing off the southeast Georgia-northeast Florida coast imply that ground-water development has drawn the interface landward only slightly from its predevelopment position (Johnston and others, 1982). Thus the source of contamination is not seawater moving laterally to wells.

Hydrogeologic and geochemical evidence gathered over a number of years (principally by Wait and Gregg, 1973) and summarized by Krause and Randolph (in press) confirms that the source of the saline water that has contaminated a large part of the Upper Floridan beneath the city of Brunswick is the Fernandina permeable zone. However, the mechanism of intrusion does not appear to be simple upconing; the high-chloride water apparently moves upward through nearly vertical zones of preferential permeability into the Upper Floridan, then laterally downgradient toward pumping centers. The evidence documented by Krause and Randolph (in press) further suggests that nearly vertical faults are the conduits that allow saline water from the Fernandina permeable zone to migrate into the upper part of the Lower Floridan and ultimately into the Upper Floridan aquifer. In 1983, an area of about $2 \mathrm{mi}^{2}$ in the Upper Floridan at Brunswick had a chloride concentration greater than $250 \mathrm{mg} / \mathrm{L}$; and, in the area of greatest saltwater contamination, the concentration was slightly more than $2,000 \mathrm{mg} / \mathrm{L}$ (Clark and others, 1984, p. 137).

Down the coast from Brunswick in the confined, heavily developed Fernandina Beach, Fla., area, increases in chloride concentration of water in the Floridan aquifer system have been measured (Leve, 1961b, 1966; Fairchild and Bentley, 1977; Brown, 1984). Monitor wells open exclusively to the Upper Floridan (that is, to depths less than about 1,200 ft) show only slight evidence of saltwater encroachment. For example, the chloride concentrations of samples from a well $1,215 \mathrm{ft}$ deep at Fernandina Beach ranged $25-30 \mathrm{mg} / \mathrm{L}$ from 1924 to 1971; concentrations rose to about $50 \mathrm{mg} / \mathrm{L}$ by 1975 . Because the middle confining unit is 
relatively impermeable locally, saltwater encroachment into the Upper Floridan may occur by vertical movement within nearby wells open to both the Upper Floridan and Lower Floridan (Fairchild and Bentley, 1977 , p. 16; fig. 12). Chloride concentrations in the Lower Floridan at Fernandina Beach are naturally higher than those in the Upper Floridan. Fairchild and Bentley (1977, figs. 10,11) show chloride concentrations from samples of selected wells open to both aquifers rising from less than $100 \mathrm{mg} / \mathrm{L}$ in 1952 to several hundred milligrams per liter by 1975 .

The conclusion among the four reports cited above is that the source of saltwater contamination at Fernandina Beach is upward migration of naturally saline water from the "deep zones" of the system (Fernandina permeable zone, beginning about $2,000 \mathrm{ft}$ below sea level). The chloride concentration of samples obtained from a deep test well at Fernandina Beach during drilling in 1979 jumped from less than $1,000 \mathrm{mg} / \mathrm{L}$ to more than $7,000 \mathrm{mg} / \mathrm{L}$ in the depth range $2,000-2,100 \mathrm{ft}$ (Brown, 1984, table 14).

To the south around Jacksonville, Leve (1983, p. 258) notes that reduction of artesian pressure has not resulted in saltwater encroachment in most places. However, selected areas exist where wells penetrating only the Upper Floridan yield water with chloride concentrations up to $650 \mathrm{mg} / \mathrm{L}$; and concentrations in many wells have increased $20-50 \mathrm{mg} / \mathrm{L}$ in the past five years (before 1982). These areas of apparent saltwater encroachment are not coincident with the major cone of depression in the Upper Floridan; they are in the vicinity of an inferred fault mapped by Leve (1978 in Leve, 1983) in eastern Duval and St. Johns Counties. Leve $(1983$, p. 259$)$ concluded that "the fault may have breached the impermeable beds in the aquifer allowing salty water from the lower zone [Fernandina permeable zone] to move vertically into the upper zones [Upper and Lower Floridan]." Thus, saltwater encroachment may occur due to the same mechanism as hypothesized at Brunswick, although to a lesser extent, in the Jacksonville area.

In contrast to the areas just described, no saltwater encroachment has occurred in the Fort Walton Beach area by the early 1980's despite the proximity of the pumping center to the coast and the deep regional cone of depression (pl. 5). Apparently, a combination of fortuitous hydrologic conditions has thus far staved off encroachment. Tight confinement above the Upper Floridan by the Pensacola Clay meant that relatively high predevelopment freshwater heads (about $40 \mathrm{ft}$ above sea level) presumably kept the freshwatersaltwater interface relatively deep at the shoreline and far offshore where it intersected the top of the aquifer system before ground-water development. If lateral movement of seawater toward wells is occurring, low transmissivity slows its shoreward migration. Trapp and others (1977, p. 71-72) attributed continuous lowchloride concentrations in the Upper Floridan at Fort Walton Beach to the "effective seal" of the aquifer by the Pensacola Clay above and clays of the Bucatunna Formation below. But the confining units above and below the Upper Floridan thin to the east; continued expansion of the regional cone of depression to the east will increase the already substantial potential for vertical encroachment (from above and below) east of the pumping center.

\section{POTENTIAL FOR FUTURE DEVELOPMENT}

Large quantities of fresh ground water are available for future development from the Floridan aquifer system. This is indicated by the fact that the original flow system has not been changed extensively by pumpage of about $3 \mathrm{Bgal} / \mathrm{d}$, which currently represents less than 20 percent of the flow through the Floridan.

Only three areas of regional head decline have been observed in the Upper Floridan aquifer (pl. 6). In all three areas, the aquifer is confined by clayey Miocene sediments. Although withdrawal from artesian storage in the Floridan has occurred, there is no dewatering. As discussed in the section on effects of ground-water development, the size and areal extent of the cones of depression are dependent upon transmissivity and the characteristics of aquifer confinement.

In contrast, pumping within the unconfined/semiconfined areas has not produced any permanent, areally extensive cones of depression. Pumpage has locally lowered the water table causing decreased hydraulic gradients toward streams thereby reducing the groundwater discharge to them. Where withdrawals are concentrated, cones of depression reach streams and induced infiltration from streams into the aquifer may occur. However, much of the unconfined/semiconfined area of south Georgia and north Florida (pl. 1) is comparatively undeveloped. An important exception is the Dougherty Plain of southwest Georgia, an area of intensive agriculture that is discussed further.

The response to future development of the Floridan will involve increases in recharge and diversions of natural discharge (primarily from streams and springs) rather than removal of large quantities of water from aquifer storage. The limiting factors on ground-water development will be deterioration of water quality and reduction of spring and stream flows. Head decline resulting from future development would likely induce poor-quality water to move into the Upper Floridan 
(both by lateral and upward movement of saltwater in coastal areas and by upconing of deep saline waters in some inland areas). Thus, any appraisal of the availability of water from the Floridan ultimately is related to maintaining the quality of water in the system. In turn this means that large head decline in coastal areas or areas underlain by poor-quality water at moderate depths should be avoided if good water quality is to be maintained. Another effect of large head decline in the unconfined/semiconfined areas is reduction in the flow of springs and streams, with consequent effects on downstream users, and perhaps in addition unacceptable environmental and aesthetic effects.

An appraisal of potentially favorable areas for large ground-water development is presented herein based primarily on minimizing head decline and thereby reducing the chances of water-quality deterioration. The potentially favorable areas were selected on the basis of aquifer and confining-unit properties, current groundwater chemistry, existing heads, and current pumping rates. The criteria that had to be met for an area to be considered "highly favorable" are as follows:

1. Transmissivity greater than $50,000 \mathrm{ft}^{2} / \mathrm{d}$ in unconfined or semiconfined areas; transmissivity greater than $100,000 \mathrm{ft}^{2} / \mathrm{d}$ in confined areas.

2. Altitude of existing heads (early 1980's) higher than $25 \mathrm{ft}$. In theory (which is conservative) this ensures at least $1,000 \mathrm{ft}$ of freshwater in the subsurface if permeable carbonate rock extends to that depth. This criterion is intended to eliminate all coastal areas where the potential for saltwater encroachment exists.

3. Freshwater in the Upper Floridan aquifer with dissolved-solids concentration of less than $500 \mathrm{mg} / \mathrm{L}$ at present. Contamination of ground water by pesticides and other toxic chemicals has been documented in a few isolated instances; however, this factor has not been considered in this evaluation.

4. Less than $40 \mathrm{ft}$ of water-level decline in the Upper Floridan due to development.

5. Current pumpage light; less than $10 \mathrm{Mgal} / \mathrm{d}$ within a $64-\mathrm{mi}^{2}$ area.

Plate 17 presents the potentially favorable areas that meet all of the five criteria listed as well as unfavorable areas. This map is intended as a qualitative overview of promising areas where large ground-water development (up to $100 \mathrm{Mgal} / \mathrm{d}$ ) can proceed with minimal detrimental effects. As shown on plate 17, most of the favorable areas occur in the lightly developed northern half of central peninsular Florida and adjoining south Georgia. Additionally, smaller favorable areas are in the northern part of the Dougherty Plain of southwest Georgia, eastern panhandle Florida (Washington and
Jackson Counties), Volusia County in east-central Florida, and the upper Kissimmee basin of south-central Florida.

Locally, of course, the effects of large, future increases of ground-water pumpage will vary. To test the effects of such increases, computer simulation was applied in some of the favorable as well as less favorable areas. Discussions of various scenarios of increased pumpage are presented in USGS Professional Papers 1403-D, $1403-\mathrm{E}, 1403-\mathrm{F}$, and 1403-H and briefly summarized here.

In the heavily developed coastal strip extending from Hilton Head, S.C., to Jacksonville, Fla., the potential for large-scale future development is small. Current withdrawals of about $470 \mathrm{Mgal} / \mathrm{d}$ have caused large water-level declines (pl. 6) and locally caused saltwater contamination or increased the potential of it (pl. 17). However, as discussed in forthcoming USGS Professional Paper 1403-D, simulation suggests that limited development can proceed within this area if the major pumping centers are avoided. For example, in Camden County, Ga., located between the Brunswick and Fernandina Beach pumping centers, a simulated withdrawal of $10 \mathrm{Mgal} / \mathrm{d}$ would result in little head decline. But the coastal area of Camden County would have to be avoided because of the natural occurrence of saline water there.

Inland from the heavily developed coastal strip of south Georgia and northeast Florida is a favorable area with enormous potential for ground-water development. A trial simulation of an increased withdrawal of $25 \mathrm{Mgal} / \mathrm{d}$ centered around Waycross, Ga., indicated little change in the potentiometric surface of the Upper Floridan and only $5 \mathrm{ft}$ of head decline in the vicinity of the pumping center. This small decline is largely due to the very high transmissivity of the Upper Floridan aquifer (about 1,000,000 $\mathrm{ft}^{2} / \mathrm{d}$ based on Waycross aquifer test 15 listed on table 2).

In the Dougherty Plain of southwest Georgia, pumpage for irrigation has increased markedly in recent years (47 Bgal in 1977 to $107 \mathrm{Bgal}$ in 1981). Withdrawals have caused water levels to drop sharply during the summer irrigation period. However, water levels rebound in the spring and over the long term there has been no reduction in aquifer storage (as of 1982). On the other hand, the pumpage has been accompanied by reductions in base flow of streams supplied by Floridan discharge (Hayes and others, 1983). Simulations described in forth-coming USGS Professional Paper 1403-H test various scenarios of increased pumpage in the Dougherty Plain. An extreme drought scenario simulates pumping during a 5-mo irrigation season assuming pumpage of about $400 \mathrm{Bgal}$; the quantity of water needed to irrigate all available agricultural land in the 
Dougherty Plain. Furthermore, a hypothetical 3-yr drought is assumed with total pumpage of about $1,200 \mathrm{Bgal}$ during three successive dry summers. Simulated head decline averaged $33 \mathrm{ft}$ following the third drought year and some dewatering of the Upper Floridan aquifer occurred. However, the primary effect was a reduction in streamflow. The mean flows of the major streams-the Flint River, Chattahoochee River, and Kinchafoonnee Creek-are severely reduced. All other streams stopped flowing. This simulation suggests that pumpage from the Floridan can supply any future irrigation needs in the Dougherty Plain; however, marked reductions in streamflow will accompany large increases in pumpage during drought years.

In the Florida panhandle, the potential for future ground-water development is limited owing primarily to the low tranmissivity of the Upper Floridan aquifer. Long-term pumpage has produced a deep regional cone of depression around Fort Walton Beach (pl. 6). However, simulations (discussed in Professional Paper 1403-H) indicate that relocating wells from the coastal area to areas of higher transmissivity inland would significantly reduce the head decline around Fort Walton Beach. Thus, the key to maximizing future development in the panhandle is to avoid locating wells in low-transmissivity coastal areas as done in the past.

In east-central Florida, pumpage of about $400 \mathrm{Mgal} / \mathrm{d}$ has only slightly altered the flow system. Although water-level declines are considerable near pumping wells, the average decline throughout the area is less than $5 \mathrm{ft}$. Spring flows have decreased less than 10 percent based on simulation. Future development from the Floridan is expected to be largely pumping for municipalities. Simulations discussed in forthcoming USGS Professional Paper 1403-E test the effect of doubling the current municipal pumping-increases do not simply double rates at existing wells but involve presumed well-field expansions. The increases involve pumping from the Lower Floridan in the OrlandoWinter Park area and the Upper Floridan elsewhere. Doubling municipal pumping rates will cause small increases in drawdown; $10 \mathrm{ft}$ or more only near the pumping centers and $20 \mathrm{ft}$ or more only near Orlando.

In west-central Florida, the population is expected to increase at a rapid rate well into the next century. Large increases in pumpage from the Floridan for municipal supplies are indicated, as discussed in USGS Professional Paper 1403-F. Current withdrawal in the southern half of the area totaling about $1 \mathrm{Bgal} / \mathrm{d}$ has produced a widespread but shallow cone of depression located southeast of 'Tampa, Fla. (pl. 6). Confined conditions exist within the cone; however, head decline abruptly ceases along its northern perimeter due to the transition to unconfined or semiconfined conditions. The northern half of the west-central Florida area (characterized largely by unconfined conditions and high transmissivity) is relatively undeveloped and represents a major future source of ground-water supplies. Except for a strip along the Gulf coast, the "northern half" is all within the "highly favorable area" shown on plate 17.

Digital simulations described in USGS Professional Paper 1403-F demonstrate the different responses to pumping in the northern and southern parts of westcentral Florida. Hypothetical well fields, each pumping $30 \mathrm{Mgal} / \mathrm{d}$, were located in Hernando County (northern part) and Manatee County (southern part). The difference in the simulated cones of depression for the two sites is striking. At the Hernando County site, the cone is shallow and of small areal extent. Pumping is largely balanced by reductions in the discharge of nearby large springs. At the Manatee County site, the cone of depression is steeper and of greater areal extentpumpage is largely derived from increased downward leakage with less than 10 percent from a reduction of spring discharge in adjoining Hillsborough County.

In summary, a considerable area of the Floridan aquifer system is highly favorable for the development of large ground-water supplies. The area is largely located inland from the coasts and characterized by high transmissivity as well as minimal development at present (1984). The major constraint on future development is degradation of water quality rather than quantity limitations. Saltwater encroachment in coastal areas and upconing of deep saline waters in some inland areas are important constraints to considar in planning additional development.

\section{SUMMARY}

The Floridan aquifer system is one of the major sources of ground-water supplies in the United States. This productive aquifer system underlies all of Florida, southeast Georgia, and small parts of adjoining Alabama and South Carolina, for a total area of about $100,000 \mathrm{mi}^{2}$. About $3 \mathrm{Bgal} / \mathrm{d}$ are currently withdrawn from the aquifer system, and, in many areas, the Floridan is the sole source of freshwater.

The Floridan aquifer system is a sequence of carbonate rocks (principally Tertiary Age limestone and dolomite) of generally high permeability that are hydraulically connected in varying degrees. The rocks vary in thickness from a featheredge in the outcrop area of Georgia, Alabama, and South Carolina to more than 
$3,500 \mathrm{ft}$ in southwest Florida. In and directly downdip from much of the Alabama-Georgia-South Carolina outcrop area, the Floridan consists of only one permeable unit. Further downdip in coastal Georgia and much of Florida, the aquifer system generally consists of Upper Floridan and Lower Floridan aquifers separated by a less-permeable confining unit. Within the Upper Floridan aquifer (and the Lower Floridan where investigated) are commonly a few highly permeable zones separated by carbonate rock whose permeability may be slightly less or much less than that of the highpermeability zones.

The Upper Floridan aquifer forms one of the world's great sources of ground water. This highly permeable unit consists principally of three carbonate units: the Suwannee Limestone (Oligocene), Ocala Limestone (upper Eocene), and Avon Park Formation (middle Eocene). Detailed local descriptions of the geology and hydraulic properties of the Upper Floridan are provided in many reports. The Lower Floridan aquifer is comparatively less known geologically and hydraulically than the Upper Floridan. Much of the Lower Floridan contains saline water.

Overlying the Floridan aquifer system in much of its area of occurrence are low-permeability clastic rocks that are called the upper confining unit. The lithology, thickness, and integrity of this confining unit has a controlling effect on the development of permeability in the Upper Floridan and flow in the Floridan locally.

The permeability of the Floridan varies greatly because of differences in the character of the waterbearing openings that include: (1) detrital units comprised of foraminiferal remains and coarse sand-sized particles that hydraulically act as sands or gravels; (2) micritic limestone occurring in panhandle Florida that acts hydraulically as a silt or clay; (3) networks of many small solution openings along joints or bedding planes that on a gross scale provide a uniform distribution of permeability; and (4) a few large cavernous openings developed in modern karst or paleokarst areas.

The transmissivity of the Upper Floridan aquifer varies by more than three orders of magnitude as a result of the wide variation in hydrogeologic conditions. The low values of transmissivity (less than 50,000 $\mathrm{ft}^{2} / \mathrm{d}$ ) occur in panhandle Florida and southernmost Florida (where the aquifer contains thick sections of lowpermeability limestone) and in the updip areas of Alabama, Georgia, and South Carolina where the aquifer is thinnest. Transmissivities are highest (greater than $1,000,000 \mathrm{ft}^{2} / \mathrm{d}$ ) in the karst areas of central and northern Florida. The hydrogeologic characteristic generally related to transmissivity is the degree of confinement. All of the very high-transmissivity area (greater than $1,000,000 \mathrm{ft}^{2} / \mathrm{d}$ ) and much of the high-transmissivity area $\left(250,000-1,000,000 \mathrm{ft}^{2} / \mathrm{d}\right)$ occur where the aquifer is either unconfined or semiconfined.

Areal variations in the transmissivity of the Lower Floridan aquifer cannot be defined because of the lack of aquifer-test data. A locally cavernous unit within the Lower Floridan termed the "Boulder Zone" (presumed to be associated with a paleokarst horizon) has an estimated transmissivity in excess of $3,000,000 \mathrm{ft}^{2} / \mathrm{d}$.

The storage coefficients calculated from aquifer-test data range from a low of $1 \times 10^{-5}$ to a high of 0.02 with most values in the $1 \times 10^{-4}$ to 0.001 range. In the Floridan aquifer system, reported storage coefficients bear no discernible relationship to thickness of aquifer tested on a regional basis.

Depending on hydrogeologic conditions and the value of storage coefficient, the time required from the start of a new pumping period for the system to reach a new steady-state condition can range from days to years. The time needed from the start of a new pumping period for the system to reach steady state in confined areas depends on the fraction of water pumped that must come from storage. If the water necessary to sustain a given pumping rate is readily available from vertical leakage (induced recharge) or from diversion of natural discharge, then only a small part of the water pumped will come from storage, and a steady-state condition will be achieved relatively quickly. Thus, leaky, hightransmissivity areas are relatively quick to reach equilibrium; conversely, relatively nonleaky, lowtransmissivity areas are relatively slow to reach equilibrium.

Values of upper confining-unit leakage coefficient derived from simulation range from less than 0.01 (in./yr)/ft $\left(2.3 \times 10^{-6}\right.$ per day) in tightly confined areas to more than 1.00 (in./yr)/ft $\left(2.3 \times 10^{-4}\right.$ per day) in semiconfined areas. The leakage coefficients calculated from aquifer-test data are generally very much larger than those obtained from simulation. In the majority of locations, leakage coefficients from aquifer-test data are too large to realistically represent the exchange of water between the surficial aquifer and the Upper Floridan. These aquifer-test values are considered to be composite or lumped properties that include leakage from all available sources.

The principal tool used to study the regional flow system was the U.S. Geological Survey's "TrescottLarson" three-dimensional finite-difference model. Modeling involved two phases: the simulation of predevelopment conditions for calibration and simulation of current (about 1980) conditions involving pumping. Both simulations assume steady-state conditions.

The estimated hydrologic budget for the approximately $94,000 \mathrm{mi}^{2}$ onshore area is as follows: $53 \mathrm{in} / \mathrm{yr}$ of rainfall is approximately balanced by $37 \mathrm{in} . / \mathrm{yr}$ of 
evapotranspiration and $16 \mathrm{in} . / \mathrm{yr}$ of runoff. The estimated regional average recharge to the Floridan aquifer system over the long term is about $5 \mathrm{in}$./yr. Simulation has shown that considerably more water recharges the Floridan today than before ground-water development. However, ground-water development has enlarged the area over which recharge occurs and shrunk the discharge area to the extent that the current rate of recharge remains about $5 \mathrm{in}$./yr over the expanded area of recharge.

Ground-water flow generally is from topographically high outcrop and central inland areas toward the Gulf and Atlantic coasts. The degree of confinement on the Upper Floridan strongly influences the distribution of natural recharge, discharge, and ground-water flow. Upper Floridan aquifer springs are the dominant feature of the predevelopment flow system. Springs and aquifer discharge to streams and lakes, nearly all of which occurs in unconfined and semiconfined areas, accounted for 88 percent of the $21,500 \mathrm{ft}^{3} / \mathrm{s}$ simulated predevelopment discharge, or about $19,000 \mathrm{ft}^{3} / \mathrm{s}$. Diffuse upward leakage, which occurs primarily in confined areas, accounted for 12 percent of the simulated predevelopment discharge, or about $2,500 \mathrm{ft}^{3} / \mathrm{s}$.

Most of the recharge necessary to sustain spring flow and aquifer discharge to streams and lakes occurred and still occurs relatively close to the springs, streams, and lakes. Average recharge rates of 15-20 in./yr are common near large springs in northwest peninsular Florida and adjacent west Florida. The proximity of high recharge to high discharge indicates a vigorous and well developed shallow flow system in the unconfined and semiconfined parts of the Upper Floridan aquifer.

Within unconfined and semiconfined areas, groundwater flow patterns are affected by variations in topography and surface drainage. In the northern outcrop area of the Floridan in Georgia, where topographic relief is relatively high and surface drainage is well developed, ground water moves primarily within the sandy hills overlying the Upper Floridan for short distances to tributary streams; only a fraction of total recharge reaches the Upper Floridan. In contrast, within the relatively flat, unconfined karstic areas of northern Florida, surface drainage is almost nonexistent. Ground water moves primarily along longer flow paths within the Upper Floridan to springs or the major streams that are well incised into the limestone; virtually all of the recharge reaches the Upper Floridan.

Ground-water flow in the parts of the predevelopmentaquifer system that are deeply buried and confinedprimarily southeast Georgia and northeast Florida, south Florida, and far-west panhandle Florida-was (and is) very sluggish compared to flow in unconfined and semiconfined areas. Springs and points of discharge to streams and lakes are practically nonexistent; discharge occurs almost exclusively by diffuse upward leakage through thick overlying sediments. As would be expected in areas of sluggish flow, rates of recharge and discharge in confined areas in general are considerably lower (less than $5 \mathrm{in}$./yr) than rates in unconfined and semiconfined areas. Confinement limits ground-water discharge, thereby restricting ground-water flow and restricting recharge. The occurrence of high transmissivity in confined parts of the system does not enhance natural ground-water flow because of restricted recharge and discharge. In contrast, the ease of ground-water discharge, particularly through springs, in unconfined and semiconfined parts of the system allows for vigorous shallow ground-water flow and high rates of recharge. High transmissivity in unconfined and semiconfined parts of the system definitely enhances ground-water flow, which in turn further increases transmissivity.

The major features of the predevelopment-flow system remain unchanged by development. Groundwater flow in general is still toward the Gulf and Atlantic coasts from topographically high outcrop and central inland areas. As in predevelopment time, Upper Floridan aquifer discharge from springs continues to be the dominant feature of the regional flow system, and the degree of confinement on the Upper Floridan is still the major hydrogeologic control on the distribution of recharge, discharge, and flow.

Similarity of the current flow system to the predevelopment flow system does not mean that ground-water development has not brought significant change. Simulation of current (about 1980) pumpage by the regional flow model indicates that development has caused the total recharge area to expand from about $67,000 \mathrm{mi}^{2}$ before development to about $76,000 \mathrm{mi}^{2}$. Simulated recharge to, and therefore discharge from, the aquifer system increased from a predevelopment total of about $21,500 \mathrm{ft}^{3} / \mathrm{s}$ to a current total of about $24,000 \mathrm{ft}^{3} / \mathrm{s}$.

Simulation indicates that about three-fourths of all discharge currently leaves the aquifer system as spring flow or discharge to surface-water bodies. The remaining one-fourth of simulated Floridan discharge is split between pumpage (17 percent) and diffuse upward leakage ( 8 percent). Pumpage has been and continues to be supplied primarily by the diversion of natural outflow from the system and by induced recharge rather than by removal of water from aquifer storage. The transient response to changes in withdrawal rates dissipates fairly rapidly (days or weeks) in most areas. Thus, on the average (that is, excluding the effects of seasonal changes in stresses) the aquifer system is considered to be approximately at equilibrium, except during periods following sustained increases in pumpage. 
If the assumption of steady-state conditions is valid, then about 60 percent of current pumpage is supplied by increased recharge. About half of the remaining 40 percent of pumpage is salvaged from spring flow and discharge to surface-water bodies and half from reduced upward leakage.

Ground-water development of the Floridan aquifer system began in the late 1800's with construction of public supply wells at Jacksonville, Fla., and Savannah, $\mathrm{Ga}$. During the years that followed, pumping steadily increased. By 1950, withdrawals from the Floridan exceeded $600 \mathrm{Mgal} / \mathrm{d}$ and, by 1980 , withdrawals were about $3 \mathrm{Bgal} / \mathrm{d}$, an annual increase of $80 \mathrm{Mgal} / \mathrm{d}$ during the 30-yr period. Pumpage has resulted in long-term regional water-level decline of more than $10 \mathrm{ft}$ in three broad areas: coastal Georgia, adjacent South Carolina, and northeast Florida; west-central Florida; and panhandle Florida.

As of 1980 , about $470 \mathrm{Mgal} / \mathrm{d}$, mostly for industrial use, were being withdrawn from the coastal strip of southeast Georiga-northeast Florida, resulting in the largest area of significant water-level change in the Floridan aquifer system. This area of regional waterlevel decline is coincident with a confined part of the Upper Floridan aquifer with little potential for increasing recharge near the centers of pumping.

In west-central Florida, about $1 \mathrm{Bgal} / \mathrm{d}$ is pumped from the Floridan aquifer primarily by the phosphate industry and for irrigation. As a result, a regional depression exists in the potentiometric surface southeast of Tampa. Although the pumping rate is greater in west-central Florida than it is in southeast Georgianortheast Florida, the area of influence and magnitude of water-level decline is smaller. Two reasons account for the smaller water-level decline: (1) leakage coefficient of the upper confining unit is generally one to two orders of magnitude greater in west-central Florida than in southeast Georgia-northeast Florida and (2) unconfined or semiconfined conditions occur near the center of heaviest pumping.

In the Fort Walton Beach area of panhandle Florida, pumping of about $20 \mathrm{Mgal} / \mathrm{d}$ has caused a regional depression in the potentiometric surface. This relatively low pumping rate has caused a regional depression because, in this area, transmissivity is very much lower than in either the southeast Georgia-northeast Florida area or the west-central Florida area and confinement is as tight as that in any other part of the aquifer system.

The Floridan aquifer system remains favorable for the development of large ground-water supplies. Favorable areas are largely inland from the coasts and are characterized by high transmissivity as well as minimal development as of the early 1980's. Simulation suggests that new pumping centers in favorable parts of south Georgia and north-central Florida can supply large withdrawals with relatively shallow cones of depression.

The response to future development will involve increases in recharge and diversions of natural discharge (primarily from streams and springs) rather than sustained withdrawals from aquifer storage. Very large withdrawals and the resulting head declines can induce poor-quality water to move into the Upper Floridan (both by lateral and upward movement of saltwater in coastal areas and by upconing of deep saline waters in some inland areas). Thus, the major constraint on future development is degradation of water quality rather than limitations of quantity. Saltwater encroachment in coastal areas and upconing of deep saline waters in some inland areas are important constraints to consider in planning additional development.

\section{APPENDIX A}

\section{MODIFICATIONS TO THE 1980 POTENTIOMETRIC-SURFACE MAP}

The May 1980 potentiometric-surface map (pl. 5) has been modified in two areas of south Florida as a result of reinterpretation of existing data and acquisition of new data. Plate 5 is based on a map by Johnston and others (1981) showing a potentiometric-surface low, or trough, surrounding small closed-contour depressions northwest of Lake Okeechobee. This low feature resulted in a closed 50 -ft potentiometric high to the south, implying that no ground-water flow from central Florida reaches southernmost Florida.

Two factors argue against the long-term existence of this closed 50-ft high. (1) Since publication of the original map, geophysical logging has determined that a number of observation wells measured in Glades County and vicinity terminate above the Upper Floridan aquifer or are not open exclusively to the Upper Floridan (R. S. Milner, U.S. Geological Survey, written commun., 1981; G. R. Schiner, U.S. Geological Survey, written commun., 1982). These non-Floridan or composite wells yield heads appreciably lower than wells tapping only the Upper Floridan. (2) Water levels since 1934 in a Floridan well (PB-203) southwest of Lake Okeechobee at Belle Glade have fluctuated over a narrow range, indicating annual replenishment of water to south Florida (F. W. Meyer, U.S. Geological Survey, written commun., 1983). The only source of replenishment is to the north of the supposed potentiometric trough in the central Florida recharge area of Polk and Highlands Counties. The 50-ft isolated high is not dissipating over time, as would be expected if the 
trough northwest of Lake Okeechobee truly represented the potentiometric surface of the Upper Floridan.

Therefore, in the modified May 1980 map of plate 5, the 50 -ft contour in south Florida has been connected to the $50-\mathrm{ft}$ contour to the north. The $60-\mathrm{ft}$ contour has been brought across the trough as well, and the $70-\mathrm{ft}$ contour extended slightly southward. The modified contours are mostly dashed to indicate that their location is of necessity approximate. After all probable nonFloridan or composite wells were eliminated in south Florida, too few measured water levels were left to locate the contours exactly.

Water-level data acquired since construction of the May 1980 map from wells known to be Floridan along the southeast Florida coast (F. W. Meyer, U.S. Geological Survey, written commun., 1983) suggest that the 40-ft contour should have been located slightly west of its position on the original published version (Johnston and others, 1981). This change has been made on the map of plate 5 .

\section{REFERENCES}

Applin, E. R., and Applin, P. L., 1964, Logs of selected wells in the Coastal Plains of Georgia: Georgia Geological Survey Bulletin 74, $229 \mathrm{p}$.

Applin, P. L., and Applin, E. R., 1944, Regional subsurface stratigraphy and structure of Florida and southern Georgia: American Association of Petroleum Geologists Bulletin, v. 28, no. 12, p. 1673-1742.

Badon Ghyben, W., 1889, Nota in verband met de voorgenomen put boring nabij Amsterdam [Notes on the probable results of the proposed well drilling near Amsterdam]: Koninkl. Inst., Ing. Tijdschr., 1888-89, The Hague, pp. 8-22.

Barenblatt, G. E., Zheltov, I. P., and Kochina, I. N., 1960, Basic concepts in the theory of homogeneous liquids in fissured rocks: Journal of Applied Mathematics and Mechanics (USSR), v. 24, no. 5, p. 1286-1303.

Barnett, R. S., 1975, Basement structure of Florida and its tectonic implications: Gulf Coast Association of Geological Societies Transactions, v. 25 , p. $122-142$.

Barr, D. E., Maristany, Augustin, and Kwader, Thomas, 1981, Water resources of southern Okaloosa and Walton Counties, northwest Florida: Northwest Florida Water Management District-Water Resources Assessment 81-1.

Bear, Jacob, 1972, Dynamics of fluids in porous media: New York, Elsevier, $764 \mathrm{p}$.

Bennison, A. P., compiler, 1975, Geological highway map of the Southeastern Region: American Association of Petroleum Geologists, U.S. Geological Highway Map Series, Map 9.

Bentley, C. B., 1977, Aquifer test analyses for the Floridan aquifer in Flagler, Putnam, and St. Johns Counties, Florida: U.S. Geological Survey Water-Resources Investigations 77-36, 50 p.

Bermes, B. J., Leve, G. W., and Tarver, G. R., 1963, Geology and ground-water resources of Flagler, Putnam, and St. Johns Counties, Florida: Florida Geological Survey Report of Investigations No. 32,97 p.

Black, A. P., Brown, Eugene, and Pearce, J. M., 1953, Salt water intrusion in Florida -1953: Florida State Board of Conservation, Water Survey and Research Paper No. 9, 38 p.
Boulton, N. S., 1963, Analysis of data from non-equilibrium pumping tests allowing for delayed yield from storage: Institute of Civil Engineers Proceedings (London), v. 26, p. 469-482.

Bradley, J. T., 1972, Climates of the states: Florida: U.S. Department of Commerce, National Oceanic and Atmospheric Administration, Climatography of the United States no. 60-8, 31 p.

Bredehoeft, J. D., Counts, H. B., Robson, S. G., and Robertson, J. B., 1976, Solute transport in ground-water systems, in Facets of Hydrology: New York, John Wiley, p. 229-256.

Bredehoeft, J. D., and Pinder, G. F., 1970, Digital analysis of areal flow in multiaquifer groundwater systems: A quasi three dimensional model: Water Resources Research, v. 6, no. 3 , p. 883-888.

Brown, D. P., 1984, Impact of development on the availability and quality of ground water in eastern Nassau County, Florida, and southeastern Camden County, Georgia: U.S. Geological Survey Water-Resources Investigations 83-4190.

Bush, P. W., 1982, Predevelopment flow in the Tertiary limestone aquifer system, southeastern United States; a regional analysis from digital modeling: U.S. Geological Survey Water-Resources Investigations $82-905,41 \mathrm{p}$.

Callahan, J. T., 1964, The yield of sedimentary aquifers of the coastal plain, southeast river basins: U.S. Geological Survey WaterSupply Paper 1669-W, 56 p.

Carter, H. S., 1969, Climates of the states: Georgia: U.S. Department of Commerce, Environmental Science Services Administration, Climatography of the United States no. 60-9, 21 p.

Carter, R. F., and Johnson, A. M. F., 1974, Use of water in Georgia, 1970, with projections to 1990: Department of Natural Resources, Earth and Water Division Hydrologic Report 2, 74 p.

Chowns, T. M., and Williams, C. T., 1983, Pre-Cretaceous rocks beneath the Georgia Coastal Plain-regional implications: p. L1-L42 in Gohn, G. S., ed., Studies related to the Charleston, South Carolina, earthquake of 1886-tectonics and seismicity: U.S. Geological Survey Professional Paper 1313.

Clark, J. S., Peck, M. F., Longsworth, S. A., and McFadden, K. W., 1984, Ground-water data for Georgia, 1983: U.S. Geological Survey Open-File Report 84-605, 145 p.

Collins, W. D., Lamar, W. L., and Lohr, E. W., 1934, The industrial utility of public water supplies in the United States, 1932: U.S. Geological Survey Water-Supply Paper 658, $135 \mathrm{p}$.

Cooper, H. H., Jr., 1963, Type curves for nonsteady radial flow in an infinite leaky artesian aquifer, in Bentall, Ray, compiler, Shortcuts and special problems in aquifer tests: U.S. Geological Survey Water-Supply Paper 1545-C, p. C48-C55.

Cooper, H. H., Jr., Kohout, F. A., Henry, H. R., and Glover, R. E., 1964, Seawater in coastal aquifers: U.S. Geological Survey WaterSupply Paper 1613-C, $84 \mathrm{p}$.

Cooper, H. H., and Warren, M. A., 1945, The perennial yield of artesian water in the coastal area of Georgia and northeastern Florida: Economic Geology, v. 40, no. 4, p. 263-282.

Counts, H. B., and Donsky, Ellis, 1963, Saltwater encroachment, geology and ground-water resources of Savannah area, Georgia and South Carolina: U.S. Geological Survey Water-Supply Paper $1611,100 \mathrm{p}$.

Counts, H. B., and Krause, R. E., 1976, Digital model analysis of the principal artesian aquifer, Savannah, Georgia, area: U.S. Geological Survey Water-Resources Investigations 76-133, 4 map sheets.

Dohrenwend, R. E., 1977, Evapotranspiration patterns in Florida: Florida Scientist, v. 40, no. 2, p. 184-192.

Duerr, A. D., and Trommer, J. T., 1981, Estimated water use in the Southwest Florida Water Management District and adjacent areas, 1980: U.S. Geological Survey Open-File Report 81-1060, $60 \mathrm{p}$.

Dyar, T. R., Tasker, G. D., and Wait, R. L., 1972, Hydrology of the 
Riceboro area, coastal Georgia: Georgia Water Quality Control Board, Final Report, 74 p.

Fairchild, R. W., 1977, Availability of water in the Floridan aquifer in southern Duval and northern Clay and St. Johns Counties, Florida: U.S. Geological Survey Water-Resources Investigations 76-98, $53 \mathrm{p}$.

Fairchild, R. W., and Bentley, C. B., 1977, Saline-water intrusion in the Floridan aquifer in the Fernandina Beach area, Nassau County, Florida: U.S. Geological Survey Water-Resources Investigations 77-32, $27 \mathrm{p}$.

Faulkner, G. L., 1973, Geohydrology of the Cross-Florida Barge Canal area with special reference to the Ocala vicinity: U.S. Geological Survey Water-Resources Investigations 73-1, 117 p.

Franks, B. J., and Phelps, G. G., 1979, Estimated drawdowns in the Floridan aquifer due to increased withdrawals, Duval County, Florida: U.S. Geological Survey Water-Resources Investigations 79-84, 22 p.

Gelbaum, Carol, 1978, The geology and ground water of the Gulf Trough: Georgia Geologic Survey Bulletin 93, p. 38-47.

Georgia Geological Survey, 1976, Geologic map of Georgia.

Gunter, Herman, and Ponton, G. M., 1931, Need for conservation and protection of our water supply with special reference to waters from the Ocala Limestone: Florida Geological Survey 21st and 22d Anniversary Reports, 1928-30, p. 43-55.

Hantush, M. S., 1960, Modification of the theory of leaky aquifers: Journal of Geophysical Research, v. 65, no. 11, p. 3713-3725.

Hantush, M. S., and Jacob, C. E., 1955, Nonsteady radial flow in an infinite leaky aquifer: American Geophysical Union Transactions, v. 36 , no. 1 , p. $95-100$.

Hayes, L. R., 1979, The ground-water resources of Beaufort, Colleton, Hampton, and Jasper Counties, South Carolina: South Carolina Water Resources Commission Report No. 9, 91 p.

Hayes, L. R., Maslia, M. L., and Meeks, W. C., 1983, Hydrology and model evaluation of the principal artesian aquifer, Dougherty Plain, southwest Georgia: Georgia Geologic Survey Bulletin 97, $91 \mathrm{p}$.

Healy, H. G., 1962, Piezometric surface and areas of artesian flow of the Floridan aquifer in Florida, July 6-17, 1961: Florida Board of Conservation, Division of Geology Map Series No. 4, 1 map sheet.

1975, Potentiometric surface and areas of artesian flow of the Floridan aquifer in Florida, May 1974: Florida Department of Natural Resources, Bureau of Geology Map Series No. 73, 1 map sheet.

1981, Estimated pumpage from ground-water sources for public supply and rural domestic use in Florida, 1977: Florida Department of Natural Resources, Bureau of Geology Map Series 102, 1 map sheet.

Heath, R. C., and Smith, P. C., 1954, Ground water resources of Pinellas County, Florida: State Board of Conservation, Florida Geological Survey Report of Investigations No. 12, 139 p.

Herrick, S. M., 1961, Well logs of the Coastal Plain of Georgia: Georgia Geological Survey Bulletin 70, $462 \mathrm{p}$.

Herrick, S. M., and Vorhis, R. C., 1963, Subsurface geology of the Georgia Coastal Plain: Georgia Geological Survey Information Circular 25, $79 \mathrm{p}$.

Herzberg, Alexander, 1901, Die Wasserversorgung einiger Nordseebader [The water supply on parts of the North sea coast]: J. Gasbeleucht. u. Wasserversorg., Jahrg. 44, Munich.

Hickey, J. J., 1979, Hydrogeologic data for the South Cross Bayou subsurface-injection test site, Pinellas County, Florida: U.S. Geological Survey Open-File Report 78-575, 87 p.

Hickey, J. J., and Barr, G. L., 1979, Hydrogeologic data for the Bear Creek subsurface-injection site, St. Petersburg, Florida: U.S. Geological Survey Open-File Report 78-853, 53 p.
Holdridge, L. R., 1967, Life Zone Ecology: Tropical Science Center, San Jose, Costa Rica.

Hubbert, M. K., 1940, The theory of ground-water motion: Journal of Geology, v. 48, no. 8, p. 785-944.

Johnston, R. H., and Bush, P. W., 1988, Summary of the hydrology of the Floridan aquifer system in Florida and in parts of Georgia, South Carolina, and Alabama: U.S. Geological Survey Professional Paper 1403-A.

Johnston, R. H., Bush, P. W., Krause, R. E., Miller, J. A., and Sprinkle, C. L., 1982, Summary of hydrologic testing in Tertiary limestone aquifer, Tenneco offshore exploratory well-Atlantic OCS, leaseblock 427 (Jacksonville NH 17-5): U.S. Geological Survey WaterSupply Paper $2180,15 \mathrm{p}$.

Johnston, R. H., Healy, H. G., and Hayes, L. R., 1981, Potentiometric surface of the Tertiary limestone aquifer system, southeastern United States, May 1980: U.S. Geological Survey Open-File Report 81-486, 1 map sheet.

Johnston, R. H., Krause, R. E., Meyer, F. W., Ryder, P. D., Tibbals, C. H., and Hunn, J. D., 1980, Estimated potentiometric surface for the Tertiary limestone aquifer system, southeastern United States, prior to development: U.S. Geological Survey Open-File Report 80-406, 1 map sheet.

Kimrey, J. O., 1978, Preliminary appraisal of the geohydrologic aspects of drainage wells, Orlando area, central Florida: U.S. Geological Survey Water-Resources Investigations 78-37, $24 \mathrm{p}$.

Kohler, M. A., Nordenson, T. V., and Baker, D. R., 1959, Evaporation maps for the United States: U.S. Weather Bureau Technical Paper 37, 13 p.

Krause, R. E., 1982, Digital model evaluation of the predevelopment flow system of the Tertiary limestone aquifer, southeast Georgia, northeast Florida, and southern South Carolina: U.S. Geological Survey Water-Resources Investigations 82-173, 27 p.

Krause, R. E., and Randolph, B. R., in press, Hydrology of the Floridan aquifer system in southeast Georgia and adjacent parts of Florida and South Carolina: U.S. Geological Survey Professional Paper 1403-D.

Leach, S. D., 1983, Source, use, and disposition of water in Florida, 1980: U.S. Geological Survey Water-Resources Investigations $82-4090,337 \mathrm{p}$.

Leahy, P. P., 1982, Ground-water resources of the Piney Point and Cheswold aquifers in central Delaware as determined by a flow model: Delaware Geological Survey Bulletin 16, 68 p.

LeGrand, H. E., and Stringfield, V. T., 1971, Development and distribution of permeability in carbonate aquifers: Water Resources Research, v. 7, no. 5, p. 1284-1294.

1973, Karst hydrology-A review: Journal of Hydrology, v. 20, p. $97-120$.

Leve, G. W., 1961a, Preliminary investigation of the ground-water resources of northeast Florida: U.S. Geological Survey Information Circular 27, 28 p.

1961b, Reconnaissance of the ground-water resources of the Fernandina area Nassau County, Florida: State Board of Conservation, Florida Geological Survey, Information Circular No. 28, 24 p. 1966, Ground water in Duval and Nassau Counties, Florida: Florida Board of Conservation, Division of Geology Report of Investigations No. 43, $91 \mathrm{p}$.

1983 , Relation of concealed faults to water quality and the formation of solution features in the Floridan aquifer, northeastern Florida, U.S.A.: Journal of Hydrology, v. 61, p. 251-264.

Leve, G. W., and Goolsby, D. A., 1969, Production and utilization of water in the metropolitan area of Jacksonville, Florida: U.S. Geological Survey Information Circular 58, $37 \mathrm{p}$.

Lichtler, W. F., Anderson, Warren, and Joyner, B. F., 1968, Water re sources of Orange County, Florida: Florida Board of Conservation, Division of Geology Report of Investigations No. 50, $150 \mathrm{p}$. 
Linsley, R. K., Jr., Kohler, M. A., and Paulhus, J. L. H., 1975, Hydrology for engineers: New York, New York, McGraw-Hill, $482 \mathrm{p}$.

Lohr, E. W., and Love, S. K., 1954, The industrial utility of public water supplies in the United States, 1952; part 1, states east of the Mississippi River: U.S. Geological Survey Water-Supply Paper $1299,639 \mathrm{p}$.

MacKichan, K. A., 1951, Estimated use of water in the United States, 1950: U.S. Geological Survey Circular 115, 13 p.

1957, Estimated use of water in the United States, 1955: U.S. Geological Survey Circular 398, 18 p.

MacKichan, K. A., and Kammerer, J. C., 1961, Estimated use of water in the United States, 1960: U.S. Geological Survey Circular 456, $44 \mathrm{p}$.

Marella, Richard, 1982, Annual water use survey: 1980: St. Johns River Water Management District, Technical Report No. 14, $166 \mathrm{p}$.

Maslia, M. L., and Hayes, L. R., in press, Hydrogeology and simulated effects of ground-water development of the Floridan aquifer system, southwest Georgia, northwest Florida, and southernmost Alabama: U.S. Geological Survey Professional Paper 1403-H.

Matthews, S. E., and Krause, R. E., 1984, Hydrogeologic data from the U.S. Geological Survey test wells near Waycross, Ware County, Georgia: U.S. Geological Survey Water-Resources Investigations 83-4204, $29 \mathrm{p}$.

Matson, G. C., and Sanford, Samuel, 1913, Geology and ground waters of Florida: U.S. Geological Survey Water-Supply Paper 319, 445 p.

McCallie, S. W., 1898, A preliminary report on the artesian-well system of Georgia: Georgia Geological Survey Bulletin 7, $214 \mathrm{p}$.

McCollum, M. J., 1964, Salt-water movement in the principal artesian aquifer of the Savannah area, Georgia and South Carolina: Ground Water, v. 2, no. 4, 5 p.

McCollum, M. J., and Counts, H. B., 1964, Relation of salt-water encroachment to the major aquifer zones, Savannah area, Georgia and South Carolina: U.S. Geological Survey Water-Supply Paper 1613-D, 26 p.

Menke, C. G., Meredith, E. W., and Wetterhall, W. S., 1961, Water Resources of Hillsborough County, Florida: State Board of Conservation, Florida Geological Survey Report of Investigations 25, $101 \mathrm{p}$.

Meyer, F. W., 1962, Reconnaissance of the geology and ground-water resources of Columbia County, Florida: Florida Board of Conservation, Division of Geology Report of Investigations No. 30, 74 p.

1974, Evaluation of hydraulic characteristics of a deep artesian aquifer from natural water-level fluctuations, Miami, Florida: Florida Geological Survey Report of Investigations No. 75, 32 p.

in press, Ground water movement in the Floridan aquifer system, South Florida: U.S. Geological Survey Professional Paper 1403-G.

Miller, J. A., 1982a, Geology and configuration of the base of the Tertiary limestone aquifer system, southeastern United States: U.S. Geological Survey Water-Resources Investigations 81-1176, 1 map sheet.

1982b, Geology and configuration of the top of the Tertiary limestone aquifer system, southeastern United States: U.S. Geological Survey Water-Resources Investigations 81-1178, 1 map sheet.

1986, Hydrogeologic framework of the Floridan aquifer system in Florida and in parts of Georgia, Alabama, and South Carolina: U.S. Geological Survey Professional Paper 1403-B, 91 p.

Miller, J. A., Hughes, G. H., Hull, R. W., Vecchioli, John, and Seaber, P. R., 1978, Impact of potential phosphate mining on the hydrology of Osceola National Forest, Florida: U.S. Geological Survey Water-Resources Investigations 78-6, $159 \mathrm{p}$.

Mills, L. R., and Ryder, P. D., 1977, Saltwater intrusion in the Floridan aquifer, coastal Citrus and Hernando Counties, Florida, 1975: U.S. Geological Survey Water Resources Investigations 77-100, 1 map sheet.

Murray, C. R., 1968, Estimated use of water in the United States, 1965: U.S. Geological Survey Circular 556, 53 p.

Murray, C. R., and Reeves, E. B., 1972, Estimated use of water in the United States in 1970: U.S. Geological Survey Circular 676, $37 \mathrm{p}$.

1977, Estimated use of water in the United States in 1975: U.S. Geological Survey Circular 765, 39 p.'

Neathery, T. L., and Thomas, W. A., 1975, Pre-Mesozoic basement rocks of the Alabama Coastal Plain: Gulf Coast Association of Geological Societies Transactions, v. 25, p. 86-99.

Parker, G. G., Ferguson, G. E., Love, S. K., and others, 1955, Water resources of southeastern Florida, with special reference to the geology and ground water of the Miami area: U.S. Geological Survey Water-Supply Paper 1255, 965 p.

Parker, G. P., 1975, Water and water problems in the Southwest Florida Water Management District and some possible solutions: American Water Resources Association, Water Resources Bulletin, v. 11, no. 1, p. 1-20.

Pascale, C. A., 1974, Water resources of Walton County, Florida: Florida Department of Natural Resources, Bureau of Geology Report of Investigations No. 76, $65 \mathrm{p}$.

Pascale, C. A., and Wagner, J. R., 1982, Water resources of the Ochlockonee River area, northwest Florida: U.S. Geological Survey Water-Resources Investigations 81-1121, $114 \mathrm{p}$.

Pierce, R. R., Barber, N. L., and Stiles, H. R., 1982, Water use in Georgia by county for 1980: Georgia Department of Natural Resources, Georgia Geologic Survey Information Circular 59, $180 \mathrm{p}$.

Piper, A. M., 1932, Ground water in north-central Tennessee: U.S. Geological Survey Water-Supply Paper 640, 238 p.

Posson, D. R., Hearne, G. A., Tracy, J. V., and Frenzel, P. F., 1980, Computer program for simulating geohydrologic systems in three dimensions: U.S. Geological Survey Open-File Report 80-421, $795 \mathrm{p}$.

Pride, R. W., Meyer, F. W., and Cherry, R. N., 1966, Hydrology of Green Swamp area in central Florida: Florida Geological Survey Report of Investigations No. 42, $137 \mathrm{p}$.

Puri, H. S., and Vernon, R. O., 1964, Summary of the geology of Florida and a guide book to the classic exposures: Florida Geological Survey Special Publication 5 (revised), 255 p.

Randolph, R.B., Krause, R. E., and Maslia, M. L., 1985, Comparison of aquifer characteristics derived from local and regional aquifer tests: Ground Water, v. 23, no. 3, p. 309-316.

Remson, I., Hornberger, G. M., and Molz, F. J., 1971, Numerical methods in subsurface hydrology: New York, Wiley-Interscience, $389 \mathrm{p}$.

Renfrow, H. B., 1970, Geological highway map of the mid-Atlantic region: American Association of Petroleum Geologists, U.S. Geological Highway Map Series, Map 4.

Rhoades, Roger, and Sinacori, M. N., 1941, Pattern of ground-water flow and solution: Journal of Geology, v. 49, no. 8, p. 785-794.

Robertson, A. F., Mills, L. R., and Parsons, D. C., 1978, Ground water withdrawn for municipal, industrial, and irrigation use in the upper Peace and Alafia River Basins, west-central Florida, 1970-74: U.S. Geological Survey Open-File Report 78-29, 59 p.

Rosenau, J. C., and Faulkner, G. L., 1975, An index to springs of Florida: Florida Department of Natural Resources, Bureau of Geology Map Series no. 63, 1 map sheet.

Rosenau, J. C., Faulkner, G. L., Hendry, C. W., and Hull, R. W., 1977, Springs of Florida: Florida Department of Natural Resources, Division of Resource Management, Bureau of Geology Bulletin No. 31,461 p. 
Ryder, P. D., 1985, Hydrology of the Floridan aquifer system in westcentral Florida: U.S. Geological Survey Professional Paper 1403-F, $78 \mathrm{p}$.

Ryder, P. D., Johnson, D. M., and Gerhart, J. M., 1980, Model evaluation of the hydrogeology of the Morris Bridge well field and vicinity in west-central Florida: U.S. Geological Survey WaterResources Investigations 80-29, $92 \mathrm{p}$.

Sever, C. W., 1969, Hydraulics of aquifers at Alapaha, Coolidge, Fitzgerald, Montezuma, and Thomasville, Georgia: Georgia Geological Survey Information Circular 36, $16 \mathrm{p}$.

Sinclair, W. C., 1978, Preliminary evaluation of the water-supply potential of the spring-river system in the Weeki Wachee area and the lower Withlacoochee River, west-central Florida: U.S. Geological Survey Water-Resources Investigations 78-74, $40 \mathrm{p}$.

Singh, U. P., Eichler, G. E., Sproul, C. R., and Garcia-Bengochea, J. I., 1983, Pump-testing the Boulder Zone, south Florida: American Society of Civil Engineering, Journal of the Hydraulics Division, v. 109 , no. 8 , p. $1152-1160$.

Slichter, C. S., 1902, The motions of underground waters: U.S. Geological Survey Water-Supply and Irrigation Paper 67, $106 \mathrm{p}$.

Spechler, R. M., 1983, Estimated irrigation water use in Florida, 1980: Florida Department of Natural Resources, Bureau of Geology Map Series 106, 1 map sheet.

Sprinkle, C. L., 1982a, Sulfate concentration in water from the upper permeable zone of the Tertiary limestone aquifer system, southeastern United States: U.S. Geological Survey Water-Resources Investigations 81-1101, 1 map sheet.

$1982 \mathrm{~b}$, Chloride concentration in water from the upper permeable zone of the Tertiary limestone aquifer system, southeastern United States: U.S. Geological Survey Water-Resources Investigations 81-1103, 1 map sheet.

1982c, Dissolved-solids concentration in water from the upper permeable zone of the Tertiary limestone aquifer system, southeastern United States: U.S. Geological Survey Water-Resources Investigations 82-94, 1 map sheet.

in press, Geochemistry of the Floridan aquifer system in Florida and in parts of Georgia, South Carolina, and Alabama: U.S. Geological Survey Professional Paper 1403-I.

Stephenson, L. W., and Veatch, J. O., 1915, Underground waters of the coastal plain of Georgia: U.S. Geological Survey Water-Supply Paper 341, $539 \mathrm{p}$.

Stewart, J. W., Goetz, C. L., and Mills, L. R., 1978, Hydrogeologic factors affecting the availability and quality of ground water in the Temple Terrace area, Hillsborough County, Florida: U.S. Geological Survey Water-Resources Investigations 78-4, $38 \mathrm{p}$.

Streltsova, T. D., 1976, Hydrodynamics of groundwater flow in a fractured formation: Water Resources Research, v. 12, no. 3, p. 405-414.

Stricker, V. A., 1983, Base flow of streams in the outcrop area of southeastern sand aquifer: South Carolina, Georgia, Alabama, and Mississippi: U.S. Geological Survey Water-Resources Investigations 83-4106, $17 \mathrm{p}$.

Stringfield, V. T., 1936, Artesian water in the Florida peninsula: U.S. Geological Survey Water-Supply Paper 773-C, p. 115-195.

1966, Artesian water in Tertiary limestone in the Southeastern States: U.S. Geological Survey Professional Paper 517, $226 \mathrm{p}$.

Theis, C. V., 1935, The relation between the lowering of the piezometric surface and the rate and duration of discharge of a well using ground water storage: American Geophysics Union Transactions, v. 16, p. $519-524$.

1936, Ground water in south-central Tennessee: U.S. Geological Survey Water-Supply Paper 677, 182 p.
Tibbals, C. H., 1981, Computer simulation of the steady-state flow system of the Tertiary limestone (Floridan) aquifer system in eastcentral Florida: U.S. Geological Survey Water-Resources Investigations $81-681,31 \mathrm{p}$.

in press, Hydrology of the Floridan aquifer system in east-central Florida: U.S. Geological Survey Professional Paper 1403-E.

Tibbals, C. H., and Frazee, J. M., Jr., 1976, Ground-water hydrology of the Cocoa well-field area, Orange County, Florida: U.S. Geological Survey Open-File Report 75-676, 67 p.

Tibbals, C. H., and Grubb, H. F., 1982, Aquifer test results, Green Swamp area, Florida: U.S. Geological Survey Water-Resources Investigations 82-35, $29 \mathrm{p}$.

Torak, L. J., 1982, Modifications and corrections to the finite difference model for simulation of three-dimensional ground-water flow: U.S. Geological Survey Water-Resources Investigations 82-4025, $30 \mathrm{p}$.

Torak, L. J., and Whiteman, C. D., Jr., 1982, Applications of digital modeling for evaluating the ground-water resources of the "2,000-foot" sand of the Baton Rouge area, Louisiana: Louisiana Department of Transportation and Development Office of Public Works, Technical Report no. 27, 87 p.

Toth, J., 1963, A theoretical analysis of groundwater flow in small drainage basins: Journal of Geophysical Research, v. 68, no. 16, p. 4795-4812.

Trapp, Henry, Jr., Pascale, C. A., and Foster, J. B., 1977, Water resources of Okaloosa County and adjacent areas, Florida: U.S. Geological Survey Water-Resources Investigations 77-9, $83 \mathrm{p}$.

Trescott, P. C., 1975, Documentation of finite-difference model for simulation of three-dimensional ground-water flow: U.S. Geological Survey Open-File Report 75-438, 99 p.

Trescott, P. C., and Larson, S. P., 1976, Supplement to Open-File Report 75-438, Documentation of finite-difference model for simulation of threedimensional ground-water flow: U.S. Geological Survey Open-File Report 76-591, 21 p.

Trescott, P. C., Pinder, G. F., and Larson, S. P., 1976, Finite-difference model for aquifer simulation in two dimensions with results of numerical experiments: Techniques of Water-Resources Investigations of the U.S. Geological Survey, Chapter C1, Book 7, $116 \mathrm{p}$.

Uchupi, Elazar, 1966, Map showing relation of land and submarine topography DeSoto Canyon to Great Bahama Bank: U.S. Geological Survey Miscellaneous Geologic Investigations Map I-475.

U.S. Department of Commerce, 1961, 1960 census of population, number of inhabitants, Alabama, Florida, Georgia, South Carolina. 1981,1980 census of population, number of inhabitants, Alabama, Florida, Georgia, South Carolina.

Vorhis, R. C., 1961, A hydrogeologic reconnaissance of reservoir possibilities in northern Lowndes County, Georgia: Georgia Mineral Newsletter, v. 14, no. 4, p. 123-129.

Wait, R. L., and Gregg, D. L., 1973, Hydrology and chloride contamination of the principal artesian aquifer in Glynn County, Georgia: Georgia Department of Natural Resources Hydrologic Report 1, 93 p.

Wait, R. L., and Leve, G. W., 1967, Ground water from JOIDES core hole J-1, in Geological Survey Research 1967: U.S. Geological Survey Professional Paper 575-A, p. A127.

Walton, W. C., 1962, Selected analytical methods for well and aquifer evaluation: Illinois Department of Registration and Education, Water Survey Division Bulletin 49, $81 \mathrm{p}$.

Warren, M. A., 1944, Artesian water in southeastern Georgia, with special reference to the coastal area: Georgia Geological Survey Bulletin 49, $140 \mathrm{p}$. 
White, W. B., 1969, Conceptual models for carbonate aquifers: Ground Water, v. 7, no. 3, p. 15-21.

Wilson, W. E., 1977, Ground-water resources of Desoto and Hardee Counties, Florida: Florida Department of Natural Resources, Bureau of Geology Report of Investigations No. 83, 102 p.

1982, Estimated effects of projected ground-water withdrawals on movement of the saltwater front in the Floridan aquifer, 1976-2000, west-central Florida: U.S. Geological Survey Professional Paper 2189, 24 p.
Wilson, W. E., and Gehardt, J. M., 1982, Simulated effects of groundwater development on the potentiometric surface of the Floridan aquifer, west-central Florida: U.S. Geological Survey Professional Paper 1217, $83 \mathrm{p}$.

Wyrick, G. G., 1960, The ground-water resources of Volusia County, Florida: Florida Geological Survey Report of Investigations No. $22,65 \mathrm{p}$.

Zimmerman, E. A., 1977, Ground-water resources of Colquitt County, Georgia: U.S. Geological Survey Open-File Report 77-56, 41 p. 


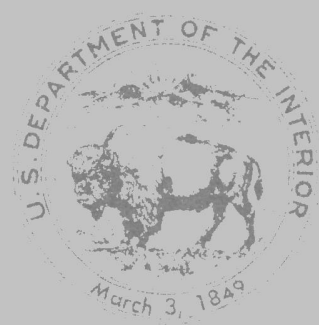

